



\section{Nordic Statistical \\ Yearbook 2014}

Nordisk statistisk årsbok 2014

Volume 52

Edited by

Klaus Munch Haagensen

Statistics Denmark

Nord 2014:001 
Nordic Statistical Yearbook 2014

Nordisk statistisk årsbok 2014

ISBN 978-92-893-3850-9 (PRINT)

ISBN 978-92-893-3854-7 (PDF)

ISSN 1398-0017

http://dx.doi.org/10.6027/Nord2014-001

Nord 2014:001

ISSN 0903-7004

(c) Nordic Council of Ministers, Copenhagen 2014

Design: Jette Koefoed, Nordic Council of Ministers, Copenhagen

Cover/omslag: Jette Koefoed/SignElements

Print/tryck: Rosendahls-Schultz Grafisk

Copies/upplaga: 700

Typeface/Typsnitt: Meta LF

Paper: Munken Polar

Printed in Denmark

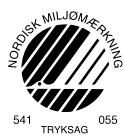

Nordic Statistical Yearbook web-site: www.norden.org/facts

Main suppliers of data: The Nordic national statistical institutes. Editor: Klaus Munch Haagensen, kmh@dst.dk, Statistics Denmark. Secretariat: Troels A. Vestergaard, tav@dst.dk, Statistics Denmark.

\section{Nordic co-operation}

Nordic co-operation is one of the world's most extensive forms of regional collaboration, involving Denmark, Finland, Iceland, Norway, Sweden and the Faroe Islands, Greenland and Åland.

Nordic co-operation has firm traditions in politics, the economy, and culture. It plays an important role in European and

international collaboration and aims at creating a strong Nordic community in a strong Europe.

Nordic co-operation seeks to safeguard Nordic and regional interests and principles in the global community. Common Nordic values help the region solidify its position as one of the world's most innovative and competitive.

\section{Det nordiska samarbetet}

Det nordiska samarbetet är ett av världens mest omfattande regionala samarbeten. Det omfattar Danmark, Finland, Island, Norge och Sverige samt Färöarna, Grönland och Åland.

Det nordiska samarbetet är politiskt, ekonomiskt och kulturellt förankra och är en viktig partner i europeiskt och internationellt samarbete. Den nordiska gemenskapen arbetar för ett starkt Norden i ett starkt Europa.

Det nordiska samarbetet vill stärka nordiska och regionala intressen och värderingar i en global omvärld. Gemensamma värderingar länderna emellan bidrar till att stärka Nordens ställning som en av världens mest innovativa och konkurrenskraftiga regioner.
Nordic Council of Ministers

Ved Stranden 18

DK-1061 Copenhagen K

Phone (+45) 33960200
Nordiska ministerrådet

Ved Stranden 18

DK-1061 København K

Telefon (+45) 33960200 


\section{Preface}

The Nordic countries have much in common - their way of life, history, language and social structure. Many of these common features and the results of their joint efforts may be described by statistics. This is why the Nordic Council of Ministers publishes the Nordic Statistical Yearbook.

This edition of the Yearbook is the $52 \mathrm{nd}$. The first edition was published in 1962. In connection with the 50 years jubilee a historical view of the development in the Nordic countries was produced. This 50 year review can be found on our webpage www.norden.org.

Our ambition is to provide comparable statistics on the life in the Nordic countries - to shed light on the similarities and the differences. Against the background of globalization, data on conditions in the Nordic in relation to other Western European countries are also provided in a number of areas. The emphasis has been on making the data easy to understand and relevant to the way we live, and thus useful in many contexts.
There is free access to a databank containing thousands of figures describing the Nordic region. The databank can be found at the Nordic Council of Ministers' website, www.norden.org. Data for the Yearbook are extracted from this databank. It is also possible to download, free of charge, the Nordic Statistical Yearbook in pdf format at www.norden.org.

\section{Enjoy your reading!}

Copenhagen, October 2014

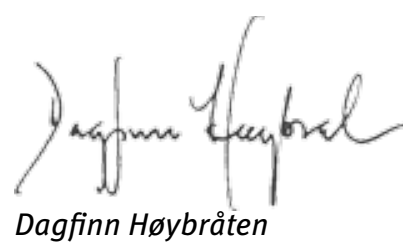

Dagfinn Høybråten

Secretary General

Nordic Council of Ministers 


\section{Förord}

De nordiska länderna har mycket gemensamt - livsstil, historia, språk och samhällsstruktur - vilket ligger till grund för en unik tradition av samarbete. Mycket av detta kan beskrivas med statistik, vilket är anledningen till att Nordiska ministerrådet ger ut Nordisk statistisk årsbok.

Denna utgåva av årsboken är den femtioandra. Den första utgåvan publicerades 1962. I samband med 50-årsjubileet tog vi fram en historisk bild av utvecklingen i Norden. Den hittar du på vår hemsida www.norden.org.

Ambitionen är att presentera jämförbar statistik om livet och livsvillkoren i de nordiska länderna - att belysa likheterna och skillnaderna. I ljuset av globaliseringen behandlas också de nordiska ländernas förhållande till det övriga Västeuropa på en rad områden. Stor vikt har lagts på att göra uppgifterna lätta att förstå och relevanta för det sätt på vilket vi lever. På så vis kan boken få många användningsområden.
Det finns fri tillgång till en databas med tusentals siffror om Norden, som ger otaliga möjligheter till intressanta analyser. Databasen finns på Nordiska ministerrådets webbplats

www.norden.org. Uppgifterna i årsboken kommer från denna databas. Det är också möjligt att kostnadsfritt läsa boken i pdf-format på hemsidan.

Mycket nöje med läsningen!

Köpenhamn i oktober 2014

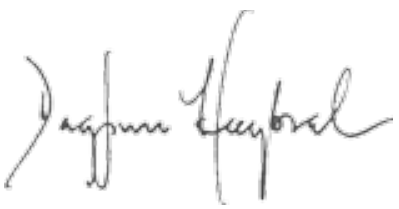

Dagfinn Høybråten

Generalsekreterare

Nordiska ministerrådet 


\section{Contents}

Preface 3

Culture

The Economy

Foreign trade

8 Public finance and prices

Facts about the Nordic countries

Sustainable development

18 Agriculture, forestry and fishery

Geography and climate

21 Science and technology

Environment and energy

28

Population

35

Appendix 1: User guide.

Appendix 2: Geonomenclature

Subject index - Swedish.

Subject index - English.

81

Elections.
92 The $\square$ and the reference that appears below a table or diagram identifies the table in the database that has served as its source. It is only a

97 selection of the data from the database that has been included in the book's tables and graphs. There is free access to the database Nordic

106 Statistics at www.dst.dk/nordicstatistics.

Throughout the book the following symbols and country codes are used: Symbols

Nil

Less than half

Not applicable

Data not available

147

To describe the different countries in the diagrams following colours are used:

Denmark:

Faroe Islands:

Euro area:

Greenland:

Finland:

Åland:

The EU:

\section{Country codes}

Denmark: DK

Faroe Islands: FO

Åland: AX

Iceland: IS

Norway: NO

Greenland: $\mathrm{G}$

Finland: $\mathrm{FI}$

Sweden: SE

Euro area: EA17 The EU: EU27 
Förord

Innehåll.

Nyckeltal - Norden i ett internationellt sammanhang ...

Fakta om de nordiska länderna

Hållbar utveckling

Geografi och klimat

Miljö och energi

Befolkning

35

Hälsa .

51

Social integration och inkomst.

Bostäder och byggande

67 Sakregister - engelska .

Kultur

Ekonomi

Utrikeshandel.

8 Offentlig ekonomi och priser

Jordbruk, skogsbruk och fiske

Vetenskap och teknologi.

Bilaga 1: Användarhandledning .

Bilaga 2: Grupperingar av länder

Sakregister - svenska

70

Utbildning

81

Arbetsmarknad

89

Val.

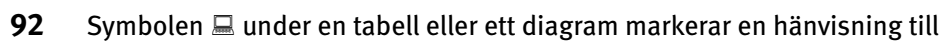
den tabell i databasen som utgör källan. Det är bara ett urval av data från

97 databasen som finns med $\mathrm{i}$ bokens tabeller och diagram. Det finns gratis tillgång till databasen Nordic Statistics på www.dst.dk/nordicstatistics.

106

129 Symboler

Noll

Mindre än hälften

Inte tillämpligt

Uppgift saknas

143

147 Följande färger används för att beskriva de olika länderna i diagrammen:

148

Danmark:

Färöarna:

Grönland:

Finland:

Åland:

Island:

EU:

\section{Landskoder}

Danmark: DK

Färöarna: FO

Grönland: GL

Finland: $\mathrm{FI}$

Euroområdet: EA1

Aland: AX

Island: IS

Norge: NO

Sverige: SE

EU: EU27 
The Nordic region in an international context - key figures. Latest available figures

Norden i ett internationellt sammanhang - nyckeltal. Senast tillgängliga uppgifter

\begin{tabular}{|c|c|c|c|c|c|}
\hline & Norden & EU & Japan & United States & \\
\hline Total land area, $1000 \mathrm{sq} \mathrm{km}$ & 1146 & 4236 & 378 & 9832 & Landareal, $1000 \mathrm{~km}^{2}$ \\
\hline Arable land, per cent of land area & 7.3 & 28.4 & 12.5 & 17.5 & Åkermark, procent av landarealen \\
\hline Forest area, per cent of land area & 56.1 & 37.7 & 68.6 & 33.3 & Skogsmark, procent av landarealen \\
\hline Population, million & 26 & 486 & 128 & 309 & Folkmängd, miljoner \\
\hline Density (inhabitants $/ \mathrm{km}^{2}$ land area) & 17 & 119 & 338 & 32 & Invånare per $\mathrm{km}^{2}$ land areal \\
\hline Total fertility rate & 1.8 & 1.6 & 1.4 & 1.9 & Summerad fruktsamhet \\
\hline Life expectancy, men & 79.9 & 77.5 & 79.9 & 76.3 & Medellivslängd, Män \\
\hline Life expectancy, women & 83.9 & 83.1 & 86.4 & 81.1 & Medellivslängd, Kvinnor \\
\hline Unemployment rate, total & 7.1 & 10.9 & 4.0 & 7.4 & Arbetslöshet, totalt \\
\hline Men & 7.3 & 10.9 & 4.3 & 7.6 & män \\
\hline Women & 6.8 & 10.9 & 3.7 & 7.1 & kvinnor \\
\hline GDP, PPP (million US \$) & 1675 & 13069 & 4792 & 17058 & BNP, PPP (miljoner USD) \\
\hline GDP per capita, PPP (US \$) & 47513 & 34083 & 37630 & 53960 & BNP per person, PPP (USD) \\
\hline Tax revenue as percentage of GDP & 44.9 & 40.7 & 28.3 & 26.9 & Skatter i procent av BNP \\
\hline Tax revenue per capita (US \$) & 27416 & 10469 & 13308 & 12599 & Skatter per person (USD) \\
\hline Total imports C.I.F (million US \$) & 437180 & 5881501 & 885843 & 2239750 & Total import CIF (miljoner USD) \\
\hline Total exports F.O.B (million US \$) & 534407 & 6063443 & 798568 & 1578815 & Total export FOB (miljoner USD) \\
\hline Trade balance (million US \$) & 94057 & 181942 & -87275 & -660935 & Handelsbalans (miljoner USD) \\
\hline Consumption of energy per person (kg oil equivalent) & 3611 & 2199 & 3539 & 6794 & Konsumtion av energi per person, $\mathrm{kg}$ oljeekvivalenter \\
\hline $\mathrm{CO}_{2}$ emissions per person (tonnes) & 7.1 & 6.8 & 9.2 & 17.6 & Utsläpp av $\mathrm{CO}_{2}$ per person (ton) \\
\hline Greenhouse gas emissions per person (tonnes $\mathrm{CO}_{2}$ equivalent) & 8.8 & 9.1 & 10.0 & 21.6 & Utsläpp av växthusgaser, $\mathrm{CO}_{2}$-ekvivalenter, ton per person \\
\hline
\end{tabular}

Sources: FAO, United Nations (UNData), Nordic Statistics (database), OECD, ILO, World Bank and UNFCCC.

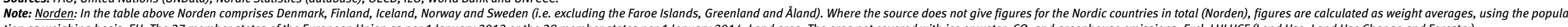
tion as weighing basis. EU:: The 27 member states of the European Union as per 1 January 2013 or the 28 member states per 1 January 2014. Land area: The area not covered with ice or water. CO, and greenhouse emissions: Excl. LULUCF (Land Use, Land Use Change and Forestry).

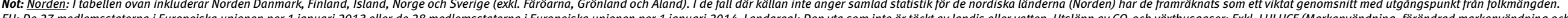

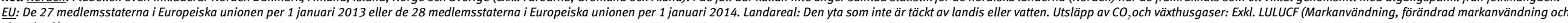




\section{The Nordic countries}

\section{Total area $(1000 \mathrm{sq} \mathrm{km})$}

$3426 \mathrm{sq} \mathrm{km}$

Arable land and gardens

(\% of land area)

Icecap and glaciers

(\% of total area)

Largest lake

5.4

51.6

Vänern $-5648 \mathrm{sq} \mathrm{km}$

(Sweden)

Gunbjørns Fjeld - 3693 m

(Greenland)

26262575

Population 1 January 2014

Inhabitants per sq $\mathrm{km}$ land area

(1 January 2014)

Fertility rate (2013)

Non-Nordic population, per cent

1.8

Intra-Nordic foreign trade

(\% of total foreign trade)

$$
\text { Imports }
$$

22.1

GDP per capita, PPS-euro (2012) 35100

Unemployment rate, per cent $\quad 7.1$

33.9

\% of total energy)

Nordic films, number of premières 133

Museums

numbers

918
48.6

Theaters, number

Secretary General

406

Official website

Dagfinn Høybråten

www.norden.org
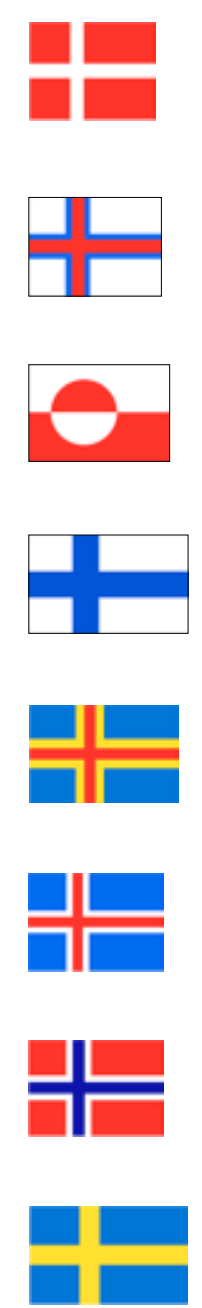

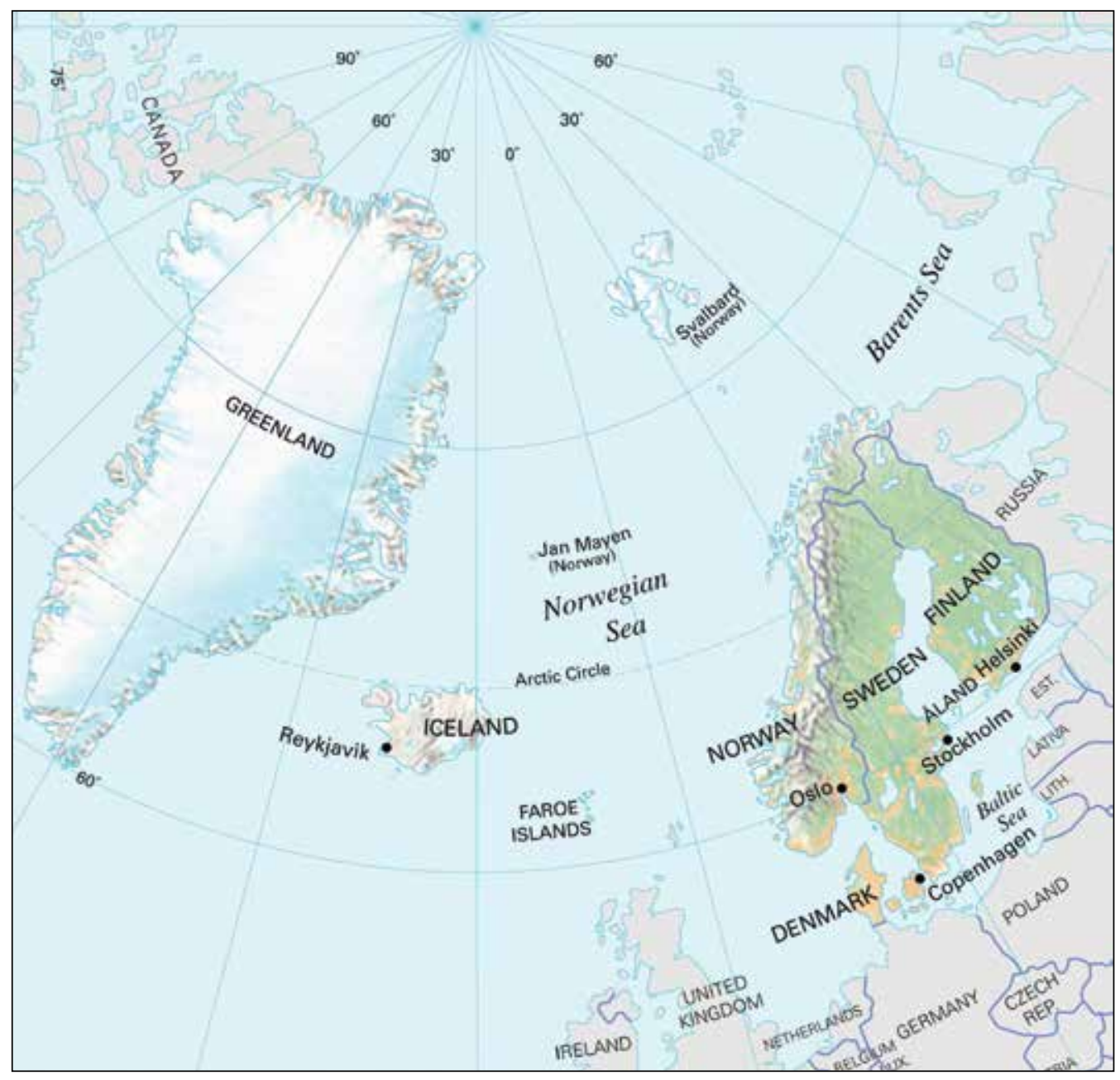

8 Facts about the Nordic countries - Fakta om de nordiska länderna 


\section{Denmark}
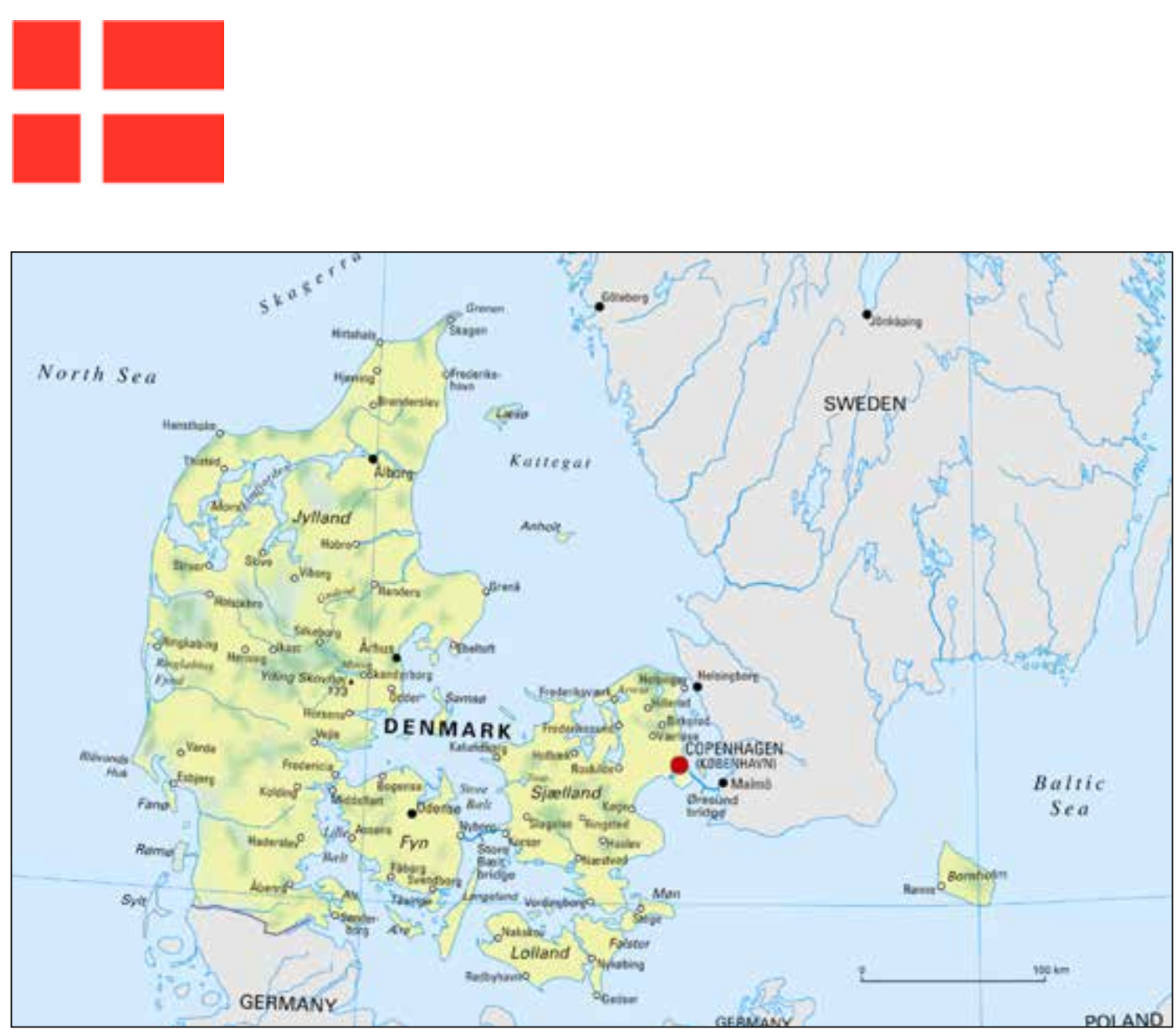

Total area

Lakes and streams

Land area

Icecap and glaciers

Arable land and gardens

Forests

Largest lake

Highest poin

Coastline

Population 1 January 2014

Population per sq km land area

1 January 2014

Capital area population

National holiday

Form of government

Parliament

Membership of EU

Membership of NATO

Head of state

Head of government

Currency

Official website

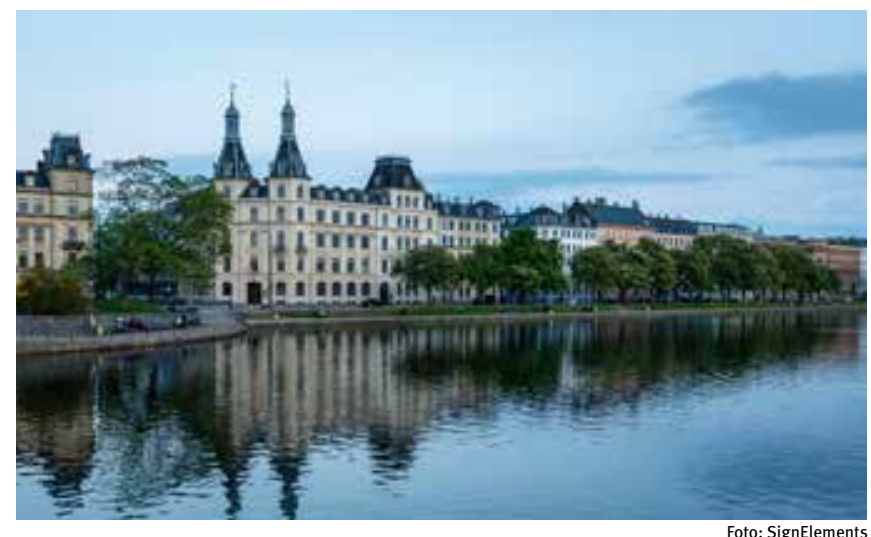

Copenhagen, Frederiksberg,

Gladsaxe, Glostrup, Herlev, Hvidov

Lyngby-Taarbæk, Rødovre, Tårnby an

parts of Ballerup, Rudersdal, Fures $\varnothing$,

Ishøj By and Greve Strand.
$43561 \mathrm{sq} \mathrm{km}$

$671 \mathrm{sq} \mathrm{km}$

$25329 \mathrm{sq} \mathrm{km}$

$5294 \mathrm{sq} \mathrm{km}$

Arres $\varnothing-39.7 \mathrm{sq} \mathrm{km}$

Yding Skovhøj-172.5 m

$7314 \mathrm{~km}$

5627235

130.5

1246611 (Copenhagen incl. suburbs)

5 June (Constitution Day 5 June 1849)

Constitutional monarchy

Folketinget (179 seats)

Yes, from 1 January 1973

Yes, from 4 April 1949

Queen Margrethe II

Prime Minister Helle Thorning-Schmidt

(The Danish Social Democrats)

Danish krone (DKK)

www.denmark.dk 


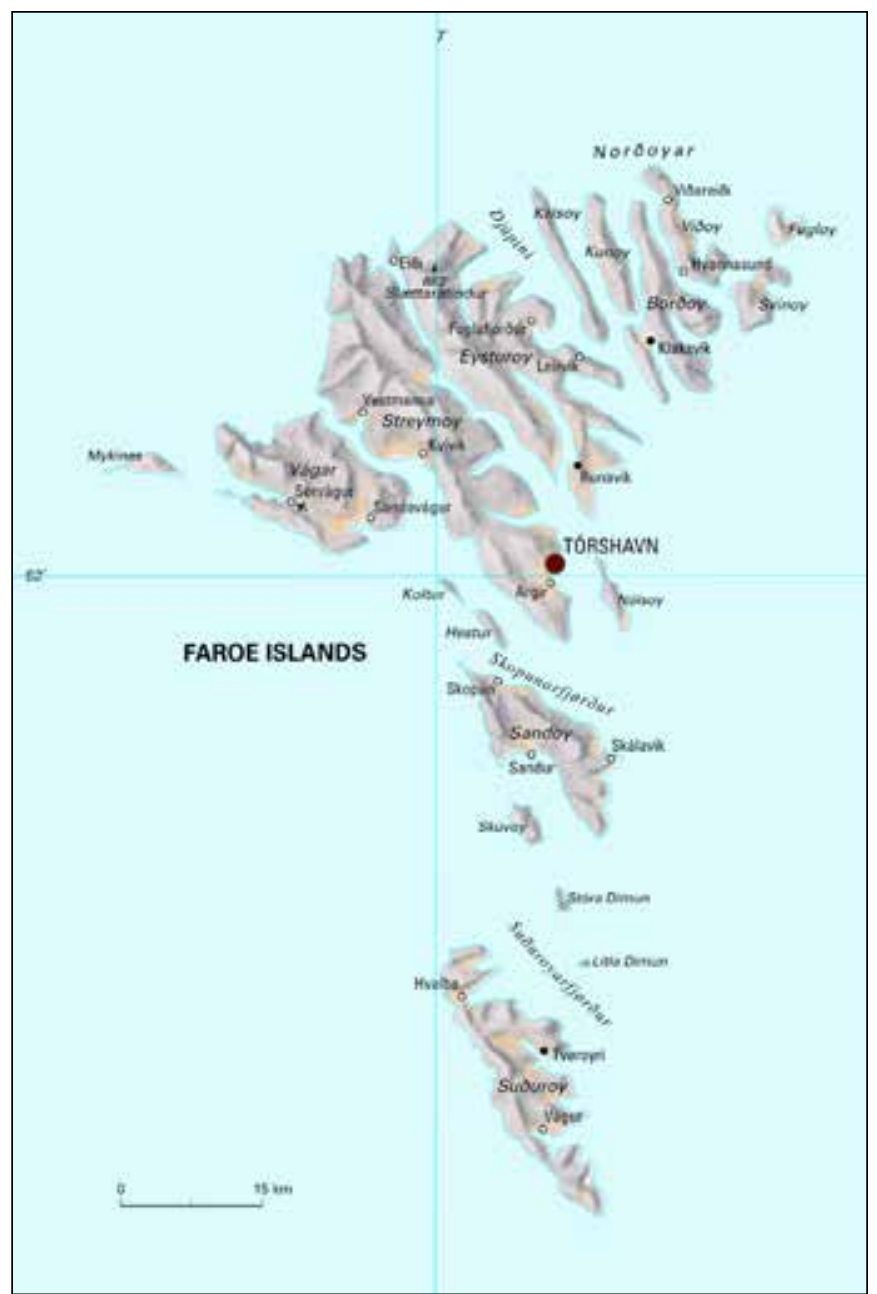

Faroe Islands

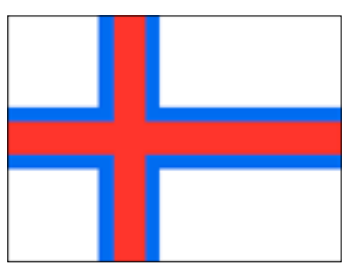

Total area

Lakes and streams

Land area

Icecap and glaciers

Arable land and gardens

Forests

Largest lake

Highest point

Population 1 January 2014

Population per square $\mathrm{km}$

total area, 1 January 2014

Capital population

National holiday

Form of government

Parliament

Membership of EU

Membership of NATO

Head of state

Head of government

Currency

Official website
$1396 \mathrm{sq} \mathrm{km}$

$9 \mathrm{sq} \mathrm{km}$

$1387 \mathrm{sq} \mathrm{km}$

$\cdot$

Leitisvatn $3.6 \mathrm{sq} \mathrm{km}$

Slættaratindur $880 \mathrm{~m}$

$1289 \mathrm{~km}$

48228

34.6

19948 (Tórshavn, municipality)

29 July (Olaifest)

Home rule - within the kingdom of Denmark

Lagtinget (33 seats)

No

Yes, since 1949

(due to the Danish membership)

Queen Margrethe II

Prime Minister Kaj Leo Johannesen

(Unionist Party)

Danish krone (DKK)

Danish krone (DKK)
www.hagstova.fo

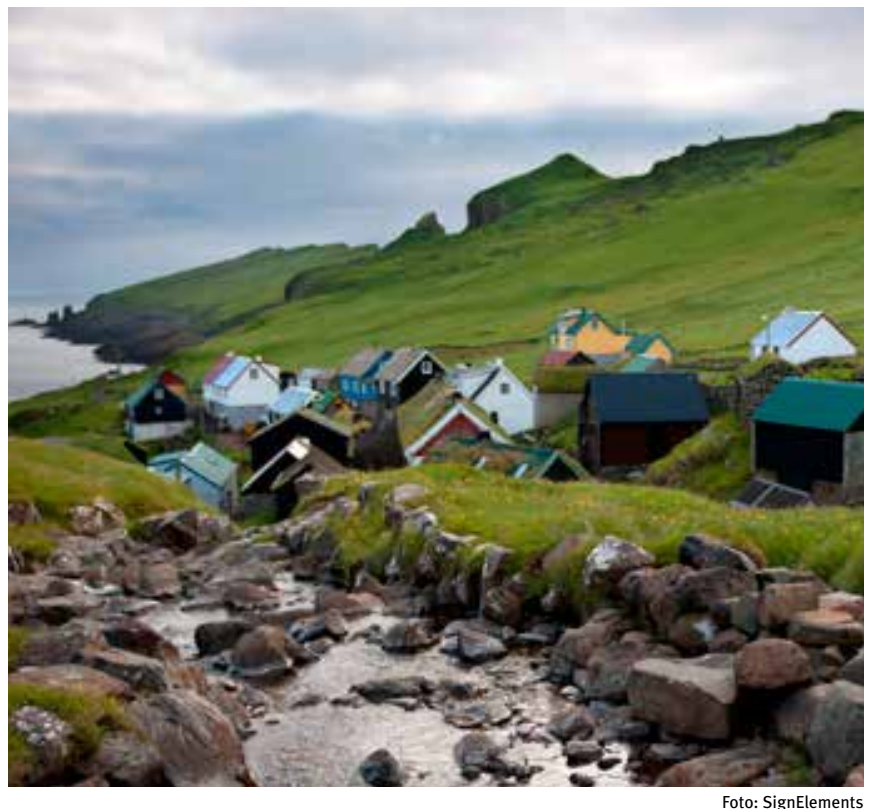

Foto: SignElements

10 Facts about the Nordic countries - Fakta om de nordiska länderna 


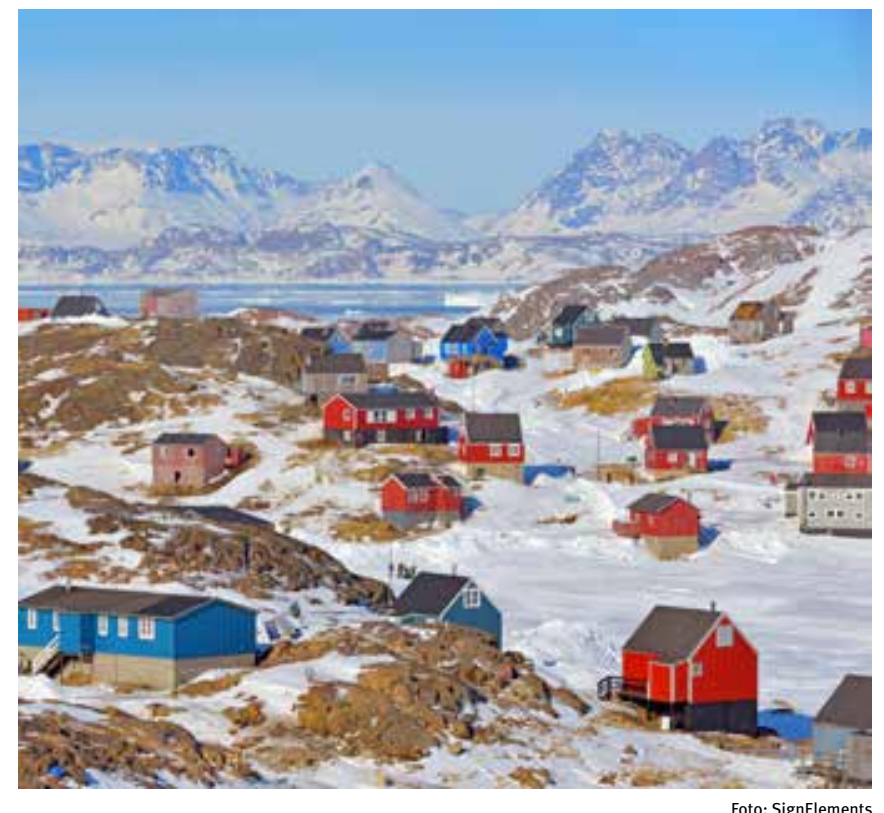

\section{Greenland}

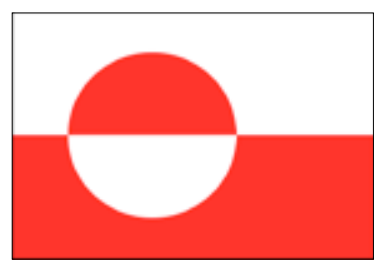

Total area

Lakes and streams

Land area

Icecap and glaciers

Arable land and gardens

Forests

Largest lake

Highest poin

Population 1 January 2014

Population per square km

ice-free land area, 1 January 2014

Capital population

National holiday

Form of governmen

Parliament

Membership of EU

Membership of NATO

Head of state

Head of government

Currency

Official website

$2166086 \mathrm{sq} \mathrm{km}$

$410449 \mathrm{sq} \mathrm{km}$

$1755637 \mathrm{sq} \mathrm{km}$

$1 \mathrm{sq} \mathrm{km}$

Gunnbjørns Fjeld $3693 \mathrm{~m}$

$44087 \mathrm{~km}$

56282

0.14

16818 (Nuuk municipality)

21 June (longest day)

Self Government - within the

kingdom of Denmark

Inatsisartut or Landstinget (31 seats)

From 1 January 1973 to 1 February 1985

Yes, since 1949 (due to the Danish

membership)

Queen Margrethe II

Aleqa Hammond (Siumut,

Social Democratic Party)

Social Democratic Paty)

www.greenland.com

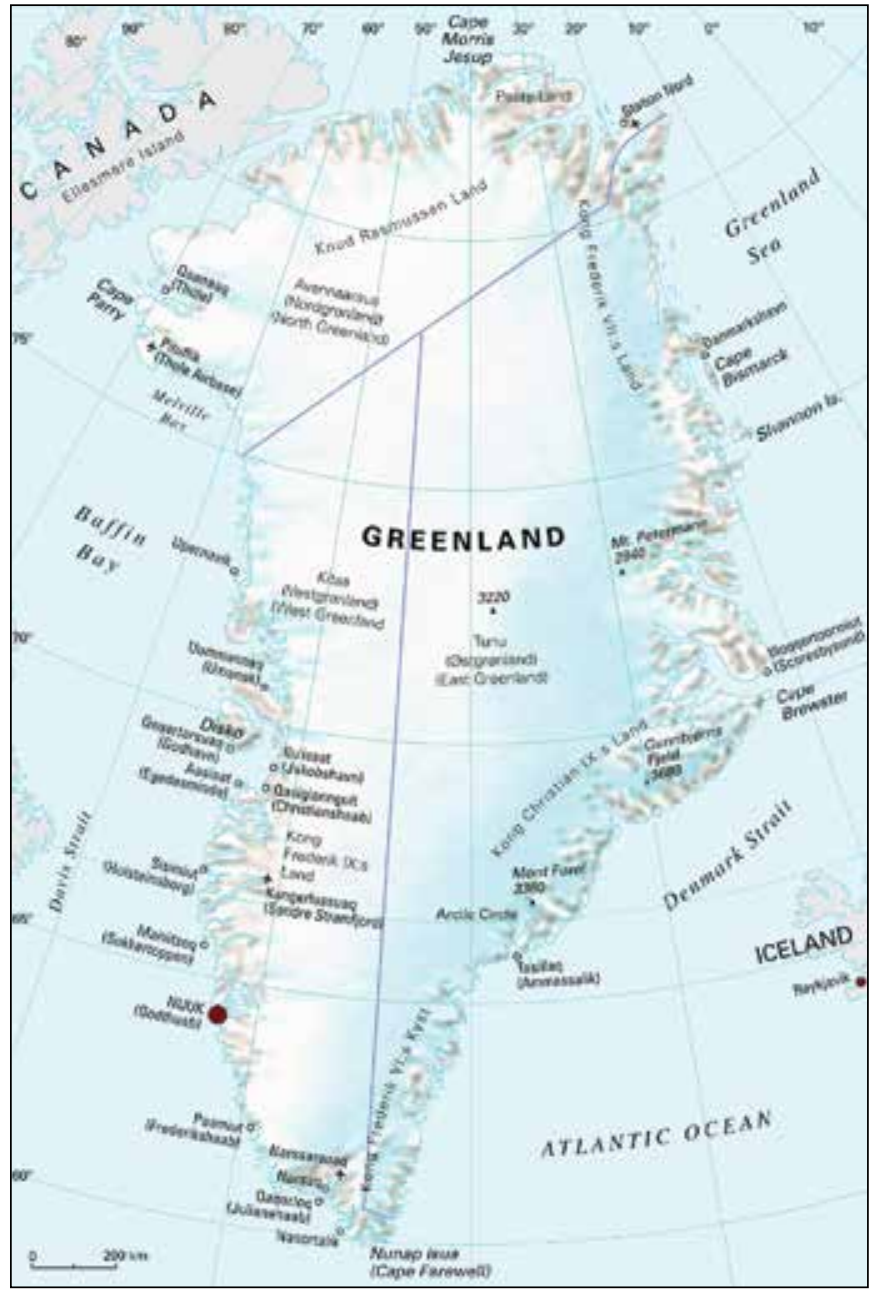

Facts about the Nordic countries · Fakta om de nordiska länderna 


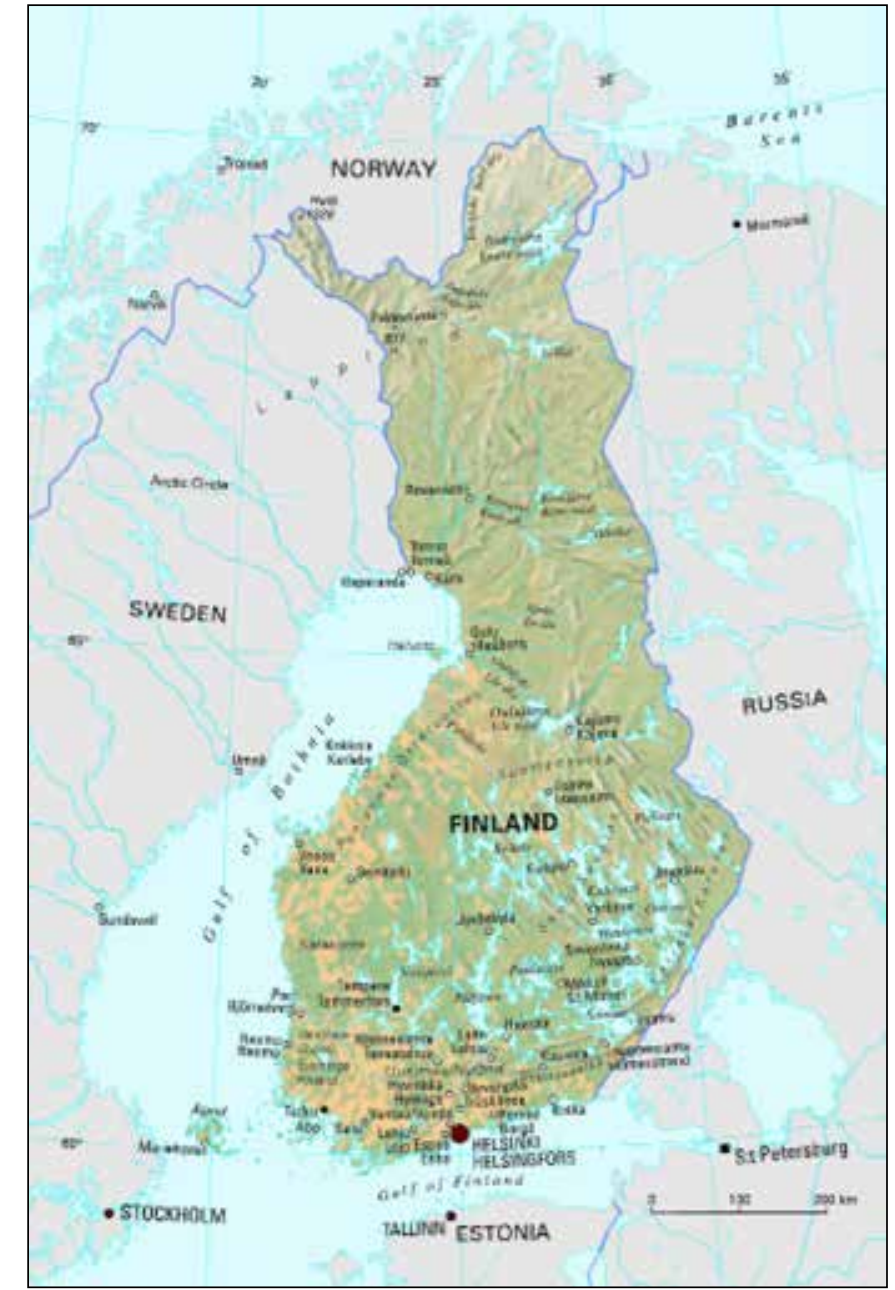

Finland

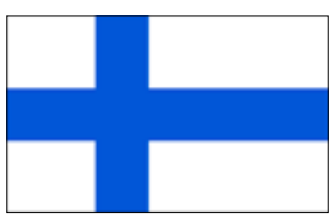

Total area

Lakes and streams

Land area

Icecap and glaciers

Arable land and gardens

Forests

Largest lake

Highest point
Coastline, mainland

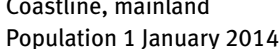

Population per square $\mathrm{km}$ land are

1 January 2014

Capital area population

National holiday

Form of government

Parliament

Membership of EU

Head of state

Head of government

Currency

Official website

* Data on Finland include Åland.
$338432 \mathrm{sq} \mathrm{km}$

$34534 \mathrm{sq} \mathrm{km}$

303320 sq km

$22897 \mathrm{sq} \mathrm{km}$

$227767 \mathrm{sq} \mathrm{km}$

Saimaa $1377 \mathrm{sq} \mathrm{km}$

Halti, Halditjåkko (Haldefjäll) $1324 \mathrm{~m}$ $6308 \mathrm{~km}$

17.9

1090616 (Helsinki/Helsingfors

incl. suburbs) ${ }^{1}$

6 December (Independence Day)

Republic

Riksdag (200 seats)

Yes, from 1 January 1995

No

President Sauli Niinistö

Prime Minister Alexander Stubb

(National Coalition Party)

Euro

www.finland.fi

1 Helsinki/Helsingfors, Espoo (Esbo), Kauniainen (Grankulla) and Vantaa (Vanda)

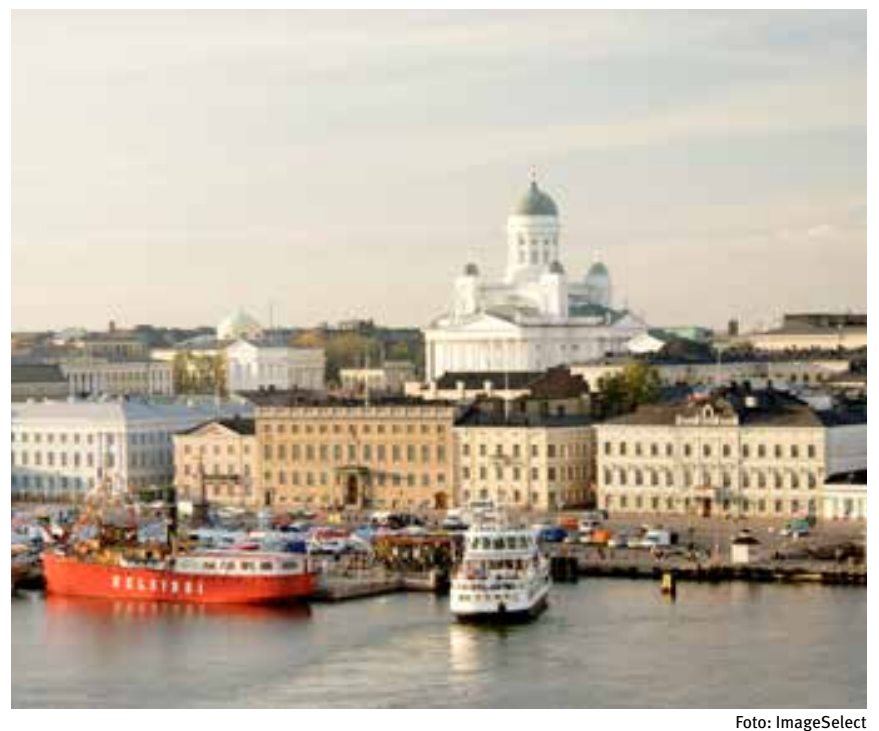

Foto: ImageSelect

12 Facts about the Nordic countries - Fakta om de nordiska länderna 


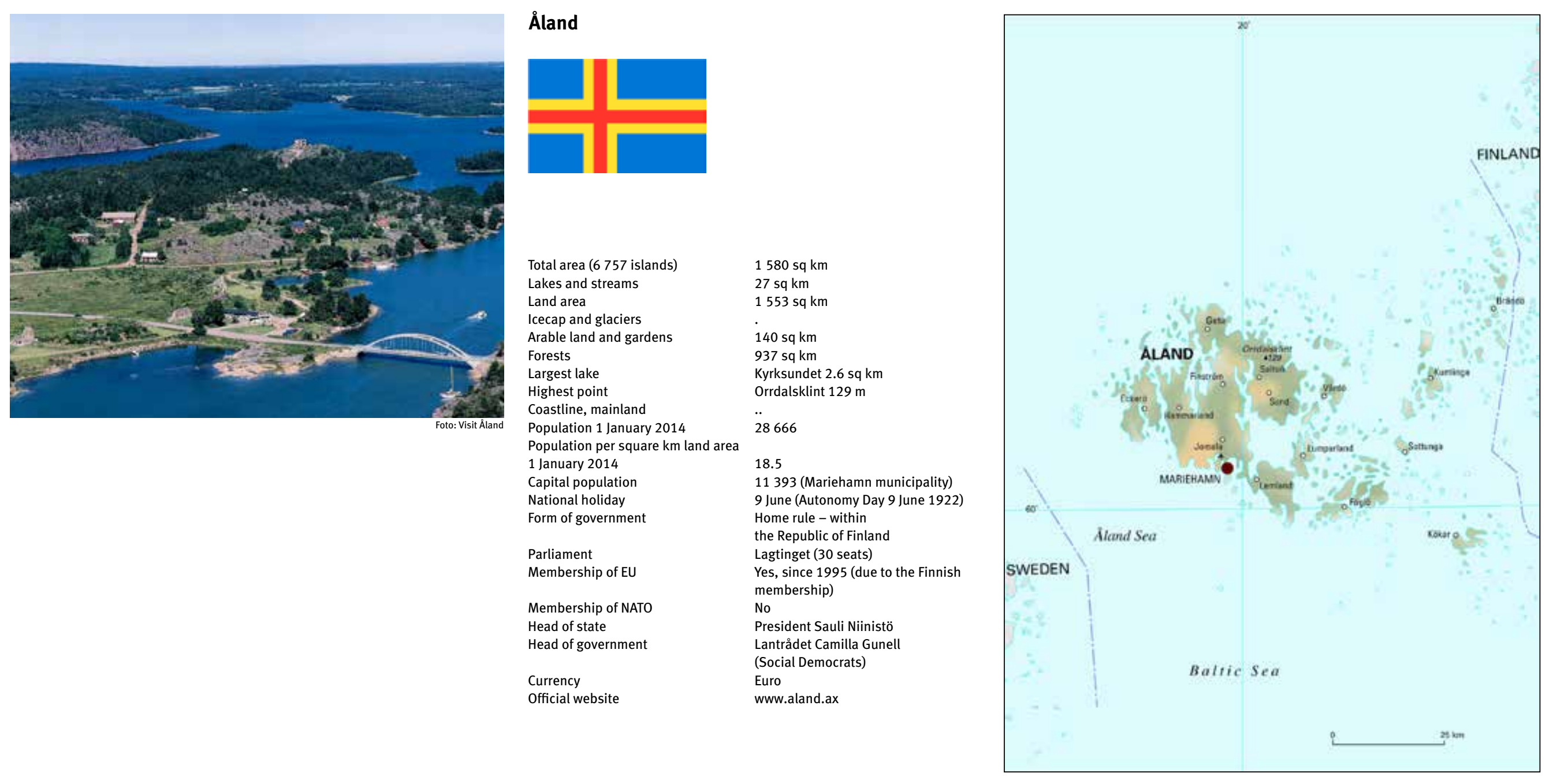




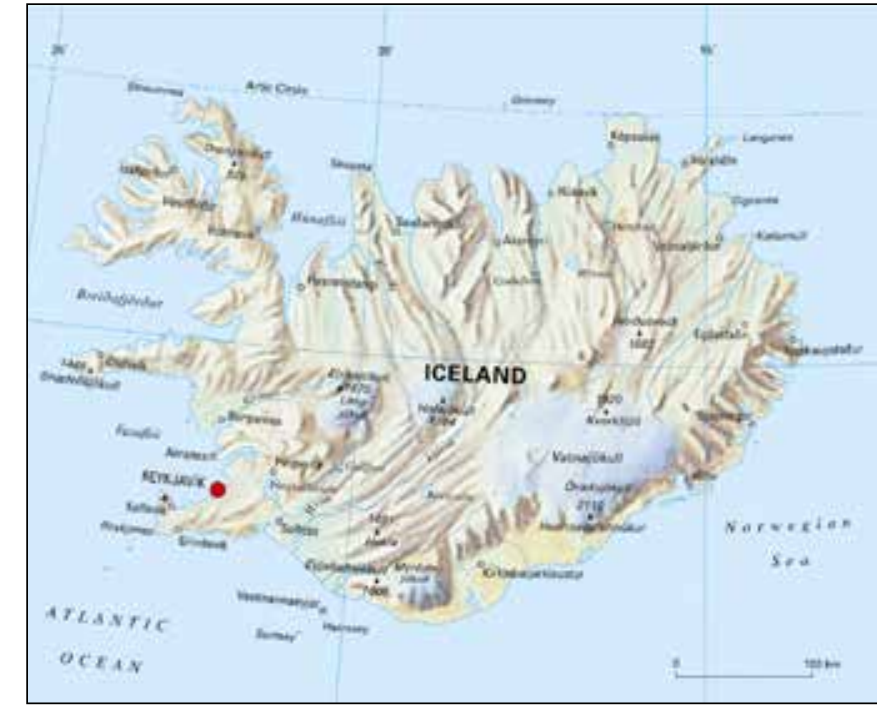

Iceland

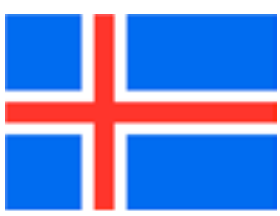

Total area

Lakes and streams

Land area

Icecap and glaciers

Arable land and gardens

Forests

Largest lake

Highest point
Coastline, mainland

Population 1 January 2014

Population per square $\mathrm{km}$ ice-fre

land area, 1 January 2014

Capital area population

National holiday

Form of Government

Parliament

Membership of EU

Membership of NATO

Head of state

Head of government

Currency

Official website
$103492 \mathrm{sq} \mathrm{km}$

$2386 \mathrm{sq} \mathrm{km}$

$89717 \mathrm{sq} \mathrm{km}$

$10900 \mathrm{sq} \mathrm{km}$

$1290 \mathrm{sq} \mathrm{km}$

$1865 \mathrm{sq} \mathrm{km}$

Mvallavatn $82 \mathrm{sq} \mathrm{km}$

Hvannadalshnúkur $2110 \mathrm{~m}$

$6088 \mathrm{~km}$

325671

208752 (Reykjavik incl. suburbs)

17 June (Independence Day 17 June 1944)

Republic

Alpingi or Althingi (63 seats)

No, but member of EEA from 1 Jan. 1994

Yes, from 4 April 1949

Ólafur Ragnar Grímsson

Prime Minister Sigmundur Davía

Gunnlaugsson (The Progressive Party)

Icelandic krona (ISK)

www.iceland.is

1 Reykjavik, Kópavogur, Seltjarnarnes,

Gardəbær, Hafnarfjörəur, Mosfellsbær and Kjósarhreppur

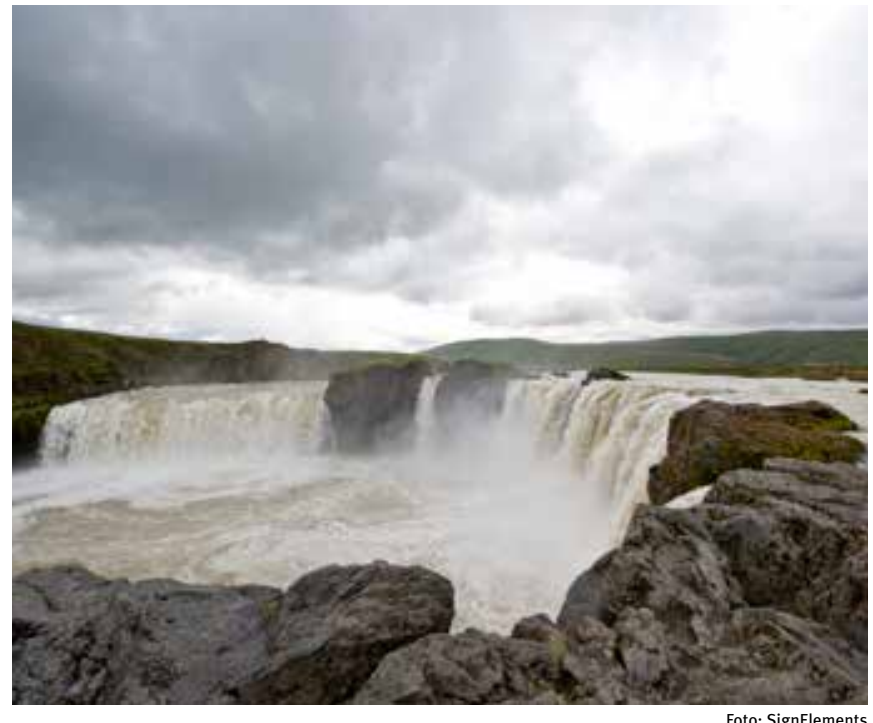

Foto: SignElements 


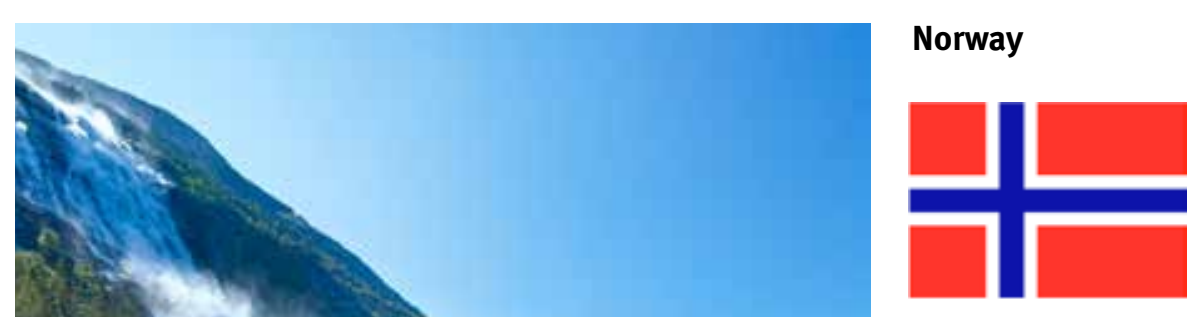

Total area ${ }^{1}$

Lakes and streams

Land area incl. icecap and glaciers

Icecap ar

Arable land and gardens

Forests

Largest lake

Highest point
Coastline, mainland

Coastline, mainland

Population 1 January 2014
Population per square $\mathrm{km}$ land are

1 January 2014

Capital area population

National holiday

Form of government

Parliament

Membership of EU

Membership of NATO

Head of state

Head of government

Currency

Official website
$323771 \mathrm{sq} \mathrm{km}$

$18351 \mathrm{sq} \mathrm{km}$

$302630 \mathrm{sq} \mathrm{km}$

$2790 \mathrm{sq} \mathrm{km}$

$125301 \mathrm{sq} \mathrm{km}$

Mjøsa $365 \mathrm{sq} \mathrm{km}$

Galdhøpiggen 2469 m

5109056

16.9

1210220 (Oslo incl. suburbs) ${ }^{2}$

17 May (Constitution Day 17 May 1814)

Constitutional monarchy

Stortinget (169 seats)

Yes, from 4 April 1949

King Harald $V$

Prime minister Erna Solberg

(The Conservative Party)

Norwegian krone (NOK)

www.norway.no

1 Excluding Svalbard and Jan Mayen

2 Oslo municipality + Akerhus county

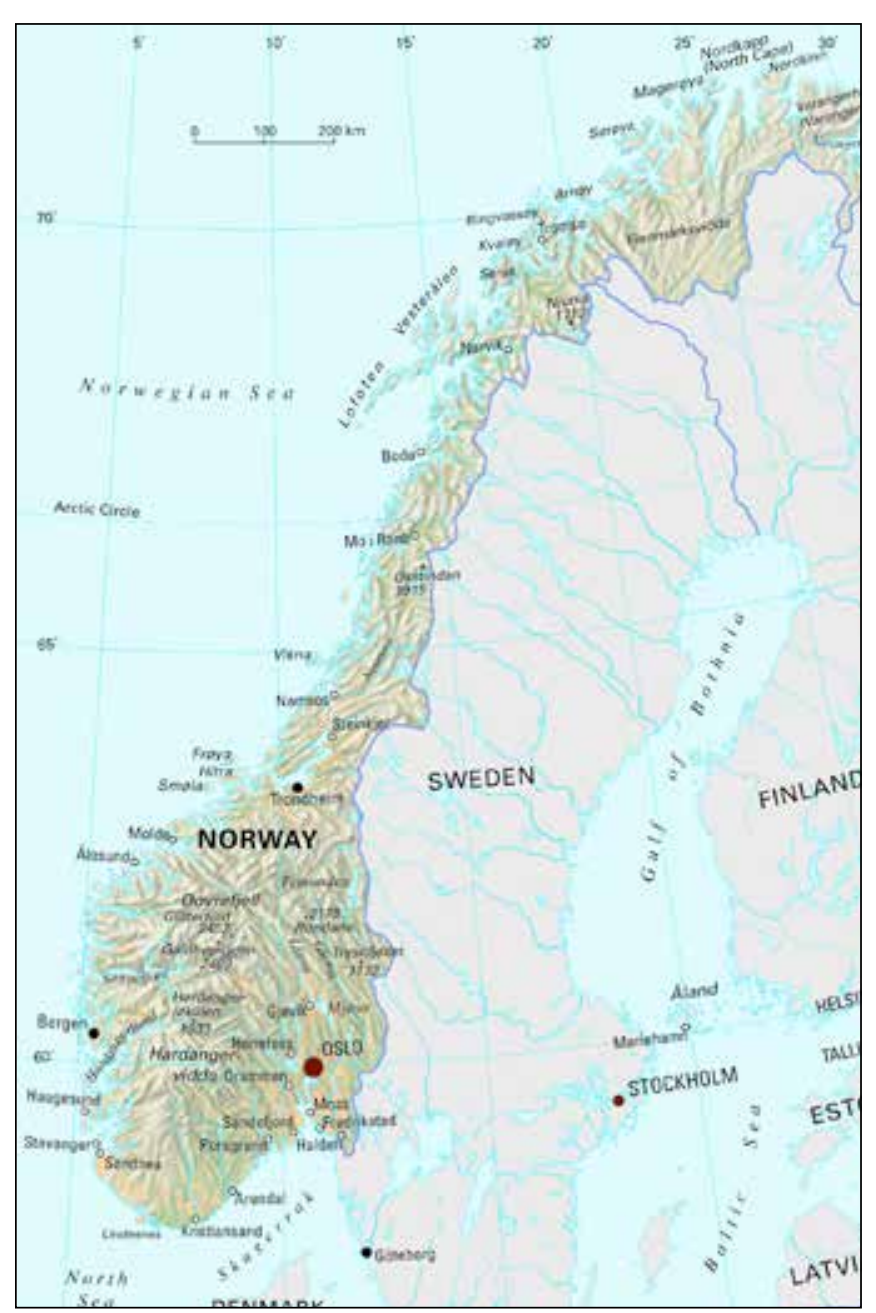




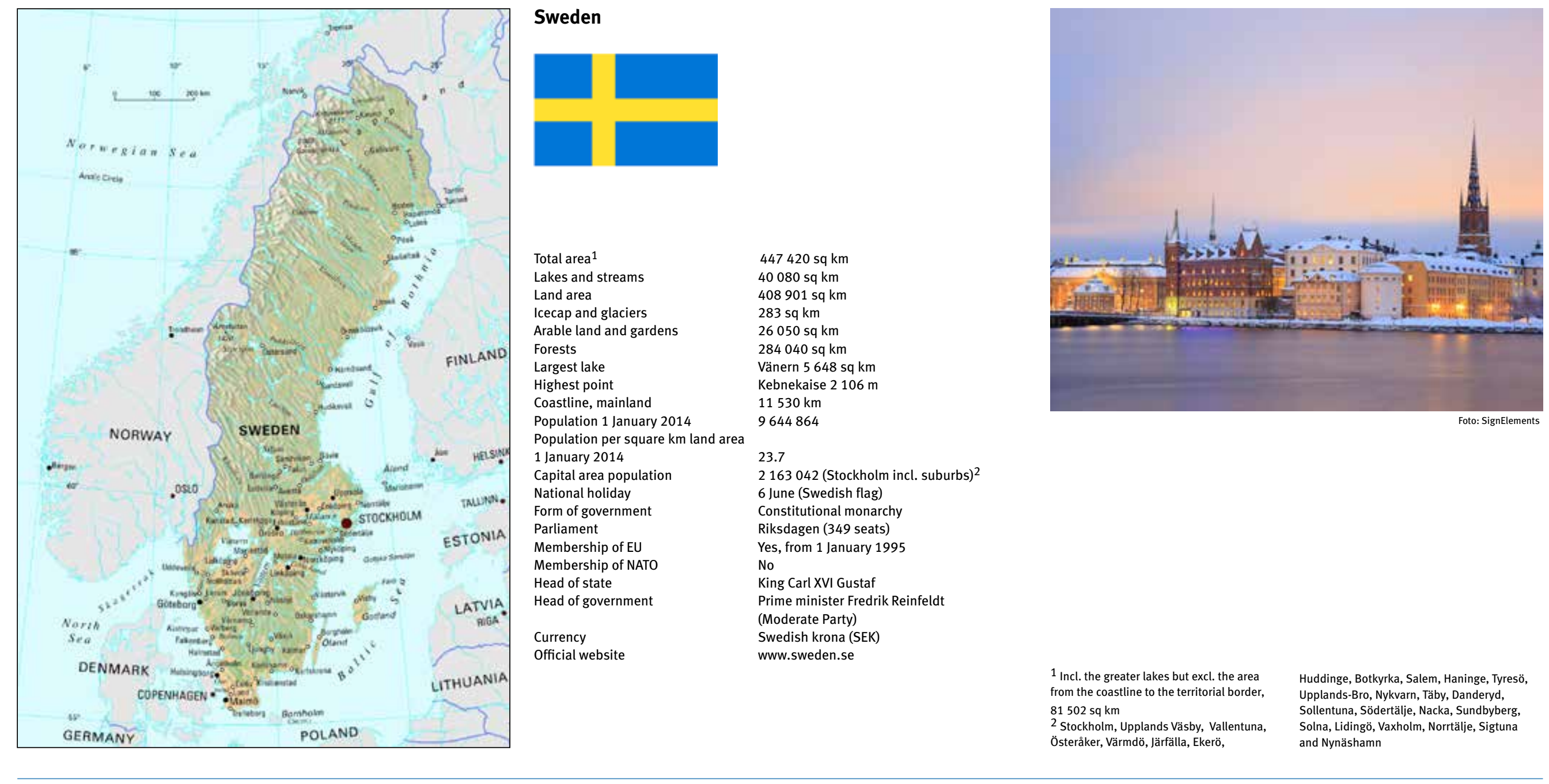

16 Facts about the Nordic countries - Fakta om de nordiska länderna 


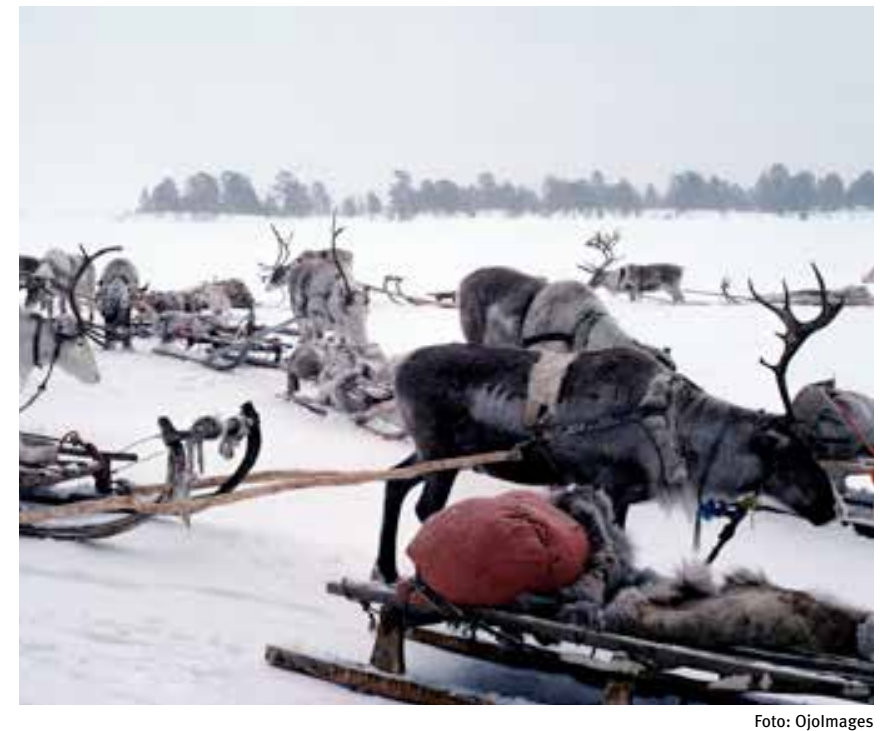

Foto: 0jolmages

Total Population

Geographic area

More detailed information

Sápmi

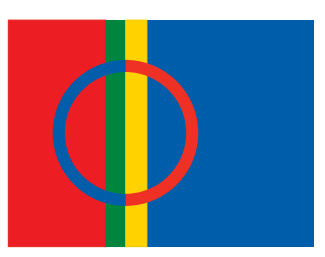

The Sami

The Sami are an indigenous people who have their traditional settlement areas in nothern Norway, Sweden, Finland and Russia. Most Sami live in Norway. Then follow Sweden and Finland, while the fewest Sami live in Russia. Because you do not make an official record of who has the Sami identity/ background, no one knows how many the Sami are. The Sami language is spoken in several variants. The Sami people are among the largest indigenous ethnic groups in Europe.

Traditionally, the Sami have plied a variety of livelihoods, including coastal fishing, fur trapping, and sheep herding. However, the best known Sami livelihood is semi-nomadic reindeer herding. For traditional, environmental, cultural and political reasons, reindeer herding is legally reserved only for Sami people in certain regions of the Nordic countries. Nowadays, the Sami work in all sectors, in line with the nonSami population, though, the primary industries are still important culture bearers for the Sami people.
Samerna

Samerna är ett ursprungsfolk som har sina traditionella bosättningsområden i norra Norge, Sverige, Finland och Ryssland. Flest samer bor det i Norge, därefter följer Sverige och Finland, medan det lägsta antalet samer bor i Ryssland. Eftersom det inte officiellt registreras vem som har samisk bakgrund är det oklart hur många samerna är. Det finns olika varianter av det samiska språket. Det samiska folket är bland de största inhemska etniska grupperna i Europa.

Traditionellt har samerna olika försörjningsformer, bland annat kustfiske, pälsfångst och fårvallning, men det mest kända samiska levebrödet är den halvnomadiska rennäringen. Av traditionella, miljömässiga, kulturella och politiska skäl är rennäringen i lag reserverad endast för samerna i vissa regioner av de nordiska länderna. I dag är samerna verksamma i alla näringar, liksom den icke-samiska befolkningen, även om primärnäringarna fortfarande är viktiga kulturbärare för samerna. 


\section{Sustainable development}

In 2013 the Nordic Council of Ministers adopted a new strategy for sustainable development called $A$ good Life in a Sustainable Nordic Region - Nordic Strategy for Sustainable Development. The new strategy provides long-term guidelines as far as 2025 within the following themes: the Nordic welfare model, viable ecosystems, changing climate, sustainable use of the earth's resources and education, research and innovation. The strategy can be found on www.norden.org/sd.

In co-operation with the Copenhagen Resource Institute a set of key indicators has been developed to describe the development within the themes of the strategy.

Several of the indicators are based on the information in the Nordic Statistical Yearbook and can be found in the relevant parts of the book. The complete set of indicators, including separate national charts, can be found on the website www.norden.org/sdindicators. The website also offers free access to the database Norden Statbank, which allows you to download data and create graphics for your own analysis.

On the next pages you can find an overview of the indicators and data for a selection of the indicators.
Hållbar utveckling

Under 2013 antog Nordiska ministerrådet en ny strategi för hållbar utveckling som kallas Ett gott liv i ett hållbart Norden - nordisk strategi för hållbar utveckling. Den nya strategin ger långsiktiga riktlinjer så långt som 2025 inom följande temaområden: den nordiska välfärdsmodellen, livskraftiga ekosystem, ett förändrat klimat, hållbar användning av jordens resur ser samt utbildning, forskning och innovation. Strategin finns på www.norden.org/sd.

I samarbete med Copenhagen Resource Institute har en rad nyckelindikatorer tagits fram för att beskriva utvecklingen inom strategins temaområden.

Flera av indikatorerna bygger på uppgifter i Nordisk statistisk årsbok och återfinns i de relevanta avsnitten i boken. Den fullständiga uppsättningen av indikatorer, inklusive diagram för enskilda nordiska länder, kan hittas på webbsidan www.norden.org/sdindicators. Webbplatsen erbjuder också gratis tillgång till databasen Norden Statbank, vilket gör att man kan ladda ner data och skapa grafik för sin egen analys.

På följande sidor hittar du en översikt av indikatorerna och data för utvalda indikatorer.

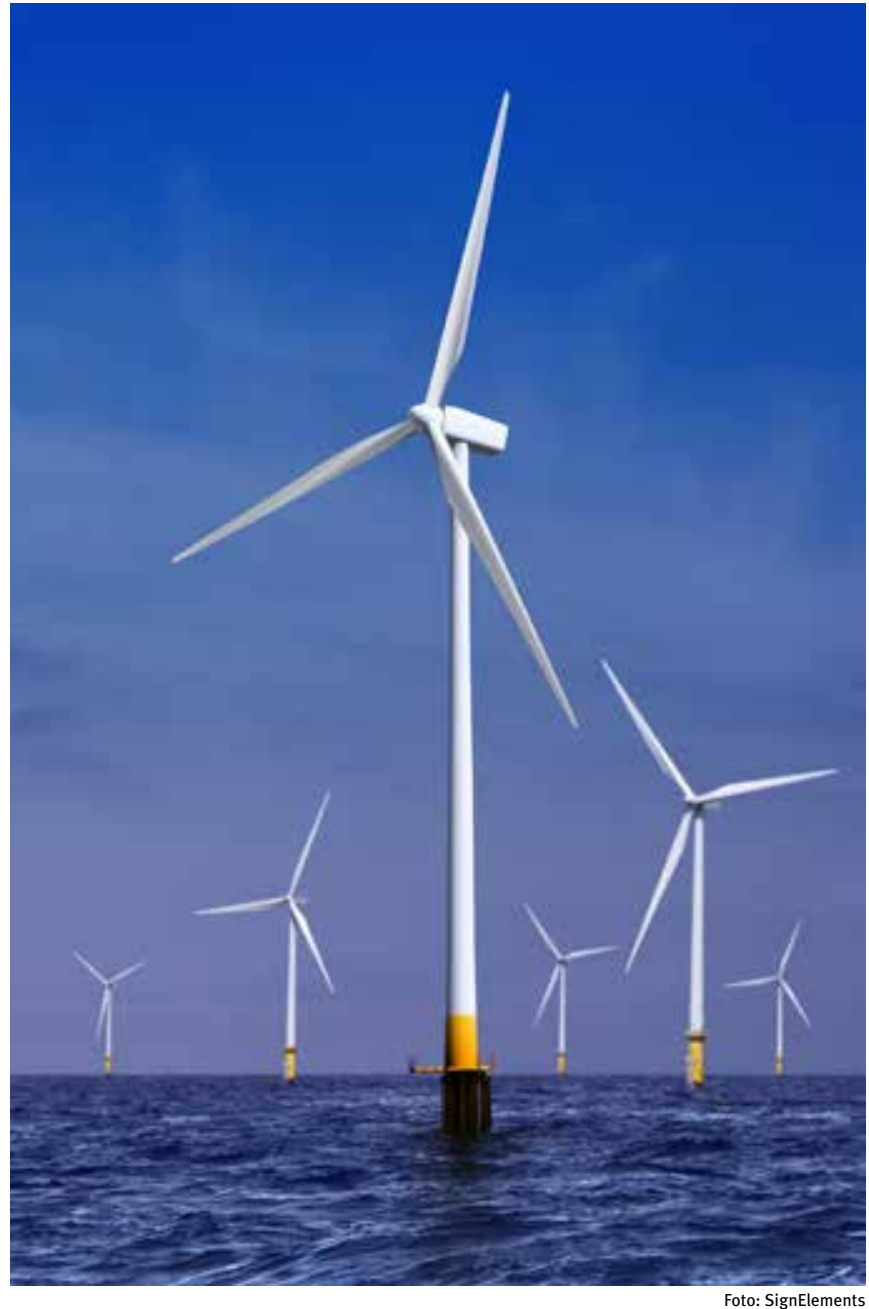

Foto: SignElements 
Sustainable development indicators

Indikatorer för hållbar utveckling

\section{www.norden.org/sdindicators}

\section{The Nordic welfare mode}

- Demographic trend

- Gross domestic product (GDP)

- Public debt

- Urbanisation

- Employment and unemployment rate

- Life expectancy at birth

- Gini-coefficient

- Risk of poverty amongst families with children

- Gender pay gap

\section{Viable ecosystems}

- Sustainability of fish stocks

- Discharge of nitrogen and phosphorus to the Baltic Sea

- Changes in the common bird index

- Developments in annual fellings and increment in forests

- Urban population exposure to air pollution by ozone and particulates

\section{Changing climate}

- Share of renewable energy in gross energy supply

- Developments in greenhouse gas emissions by sector

- Emissions from land use, land use change and forestry
Sustainable use of the Earth's resources

- Decoupling of environmental pressures, gross energy consumption, resource use and generation of non-mineral use from economic growth

- Nordic Ecolabel ("the Swan") and the EU Ecolabel

- Proportion of environmental taxes in total tax revenues

- Development in municipal waste generation and in municipal waste management by treatment method

\section{Education, research and innovation}

- Upper- and post secondary and tertiary educational attainment in total population

- R\&D expenditure in per cent of GDP by sector of performance

Den nordiska vålfärdsmodellen

- Demografisk utveckling

- Bruttonationalprodukten (BNP)

- Statsskuld

- Urbanisering

- Sysselsättnings- och arbetslöshetssiffror

- Förväntad livslängd vid födseln

- Ginikoefficient

- Risk för fattigdom bland familjer med barn

- Lönegap mellan könen

Livskraftiga ekosystem

- Hållbarhet av fiskbestånd

- Utsläpp av kväve och fosfor i Östersjön
- Förändringar i indexen över vanliga fågla

- Utvecklingen av den årliga avverkningen och ökningen i skogen

- Befolkningen i städernas exponering för luftföroreningar av ozon och partiklar

Ett förändrat klimat

- Andel förnybar energi i bruttoenergiförsörinningen

- Utvecklingen av växthusgasutsläppen uppdelat på sektor

- Utsläpp från markanvändning, förändrad markanvändning och skogsbruk

Hållbart nyttjande av jordens resurser

- Frikoppling av belastning på miljön, bruttoenergiförbrukning, resursanvändning och generering av icke-mineralavfall från ekonomisk tillväxt

- Nordiska miljömärket Svanen och EU Ecolabel

- Andelen miljöskatter av de totala skatteintäkterna

- Utvecklingen av uppkomsten av kommunalt avfall och kommunal avfallshantering enligt hanteringsmetod

Utbildning, forskning och innovation

- Andel av befolkningen som har avlagt gymnasial-, eftergymnasial- och universitetsutbildning

- Utgifter för forskning och utveckling i procent av BNP, uppdelat på sektor 
Utvalda indikatorer för hållbar utveckling

\begin{tabular}{|c|c|c|c|c|c|c|c|c|c|c|}
\hline & Denmark & $\begin{array}{r}\text { Faroe } \\
\text { Islands }\end{array}$ & Greenland & Finland & Åland & Iceland & Norway & Sweden & EU27 & \\
\hline Population development $1990=100$ & & & & & & & & & & Befolkningsutveckling, 1990=100 \\
\hline 1990 & 100.0 & 100.0 & 100.0 & 100.0 & 100.0 & 100.0 & 100.0 & 100.0 & 100.0 & 1990 \\
\hline 2014 & 109.6 & 101.0 & 101.3 & 109.6 & 118.3 & 128.3 & 120.7 & 113.1 & 107.1 & 2014 \\
\hline Gross domestic product, PPS-euro per person & & & & & & & & & & $B N P$, PPS-euro per person \\
\hline 1995 & 19300 & .. & .. & 15800 & 21300 & 20765 & 19800 & 18300 & 18300 & 1995 \\
\hline 2012 & 32000 & .. & .. & 29100 & $33600^{4)}$ & 28500 & 49900 & 32700 & 25600 & 2012 \\
\hline Gross debt in the public sector, per cent of GDP & & & & & & & & & & Offentliga sektorns bruttoskuld, procent av BNP \\
\hline 2000 & 52.4 & .. & .. & 43.8 &.. & 38.7 & 29.2 & 53.9 & 61.9 & 2000 \\
\hline 2012 & 45.8 & .. & .. & 53.3 & .. & 99.5 & 29.9 & 38.2 & 85.3 & 2012 \\
\hline Unemployment rate & & & & & & & & & & Arbetslöshet, procent \\
\hline 1990 & 8.5 & $11.5^{2)}$ & & 3.2 & 0.7 & $2.7^{1)}$ & 3.5 & 1.7 & & 1990 \\
\hline 2013 & 7.2 & 3.9 & $9.8^{5)}$ & 8.3 & $3.2^{4)}$ & 5.5 & 3.6 & 8.2 & 10.9 & 2013 \\
\hline Life expectancy at birth, men & & & & & & & & & & Medellivslängd, män \\
\hline 1990 & 72.0 & 72.6 & 60.7 & 70.9 & 74.7 & 75.0 & 73.4 & 74.8 & 74.5 & 1990 \\
\hline 2013 & 78.0 & 79.3 & $68.3^{5)}$ & 77.8 & $81.2^{5}$ & 80.8 & 79.3 & 80.1 & 77.4 & 2013 \\
\hline Life expectancy at birth, women & & & & & & & & & & Medellivslängd, kvinnor \\
\hline 1990 & 77.7 & 79.7 & 68.4 & 78.9 & 82.8 & 80.1 & 79.8 & 80.4 & 80.9 & 1990 \\
\hline 2013 & 81.9 & 83.4 & $73.0^{5)}$ & 83.8 & $84.2^{5}$ & 83.9 & 83.6 & 83.7 & 83.2 & 2013 \\
\hline Risk of poverty, per cent of population & & & & & & & & & & Risk för fattigdom, procent av befolkningen \\
\hline 2004, single parent with children & 16.5 & .. & .. & 17.2 &.. & 21.9 & 16.3 & 19.8 & & Ensamstående med barn, 2004 \\
\hline 2012, single parent with children & 18.7 & .. & .. & 22.0 & .. & 24.5 & 20.4 & 34.5 & 34.2 & Ensamstående med barn, 2012 \\
\hline Renewables' share of the energy supply & & & & & & & & & & Förnybara energikällor, andel av energitillgången \\
\hline 1990 & 5.7 &.. & 0.5 & 19.0 & .. & 64.8 & 52.7 & 24.4 & 4.2 & 1990 \\
\hline 2012 & 22.6 & .. & 13.3 & 22.6 & .. & $85.8^{4)}$ & $42.3^{5)}$ & 31.6 & 10.9 & 2012 \\
\hline Emission of greenhouse gases index 1990=100 & & & & & & & & & & Utsläpp av växthusgaser index 1990=100 \\
\hline 1990 & 100.0 & .. & 100.0 & 100.0 & .. & 100.0 & 100.0 & 100.0 & 100.0 & 1990 \\
\hline 2012 & 75.2 & .. & $115.9^{4)}$ & 89.7 & .. & $125.8^{4)}$ & $105.0^{4)}$ & 79.2 & 80.1 & 2012 \\
\hline Environmental taxes, per cent of total taxes & & & & & & & & & & Miljöskatter, procent av de totala skatteintäkterna \\
\hline 2000 & 9.1 & .. & .. & 6.4 & .. & 9.6 & 8.8 & 5.9 & 6.7 & 2000 \\
\hline 2012 & 8.1 & .. & .. & 7.0 & .. & 5.7 & 5.6 & 5.6 & 5.7 & 2012 \\
\hline $\begin{array}{l}\text { Tertiary education achieved, } \\
\text { per cent of age group 15-74 years }\end{array}$ & & & & & & & & & & $\begin{array}{l}\text { Uppnådd utbildning på universitets- och } \\
\text { högskolenivå, procent av åldersgrupp 15-74 år }\end{array}$ \\
\hline 2000 & 17.9 &. & & 24.6 & 22.4 & 17.4 & 23.2 & 17.8 & $16.6^{3)}$ & 2000 \\
\hline 2013 & 26.3 & .. & $11.1^{5)}$ & $30.3^{5)}$ & 23.5 & 28.2 & 30.7 & 27.6 & 23.8 & 2013 \\
\hline$R \& D$ expenditure in per cent of GDP & & & & & & & & & & FoU-utgifter i procent av BNP \\
\hline 1995 & 1.8 & & .. & 2.3 & .. & 3.3 & 1.5 & 1.7 & 1.8 & 1995 \\
\hline 2012 & 3.0 & .. & .. & 3.6 & .. & 3.1 & 1.7 & 3.4 & 2.1 & 2012 \\
\hline
\end{tabular}

20 Sustainable development · Hållbar utveckling 


\section{Geography and climate Geografi och klimat}

The Nordic countries cover an area of almost 3.5 million square kilometres. The southernmost point is called Gedser and is located on the island of Falster in Denmark at $55^{\circ}$ North. The northernmost point is Nordkapp in Norway which is located at $71^{\circ}$ North. Three of the Nordic capitals - Oslo, Stockholm and Helsinki - are located close to the same latitude as the southernmost point of Greenland.

Despite their northern location, the Nordic countries generally have a mild climate compared to other countries at the same latitude. This is mainly due to the Gulf Stream. The further you get from the Atlantic Ocean and the Gulf Stream the colder it gets during the winters. Bergen at the west coast of Norway normally has a temperature above zero in February while Helsinki in Finland normally will have a temperature of $7-8^{\circ} \mathrm{C}$ below zero during the same month.
De nordiska länderna har en total areal på nästan 3,5 miljoner $\mathrm{km}^{2}$. Den sydligaste punkten kallas Gedser och ligger på ön Falster i Danmark vid $55^{\circ} \mathrm{N}$. Den nordligaste punkten är Nordkap i Norge som ligger på $71^{\circ} \mathrm{N}$. Tre av de nordiska huvudstäderna Oslo, Stockholm och Helsingfors - ligger nära samma breddgrad som den sydligaste punkten på Grönland.

Trots det nordliga läget har de nordiska länderna överlag ett milt klimat jämfört med andra länder på samma breddgrad. De är främst på grund av Golfströmmen. Ju längre du kommer från Atlanten och Golfströmmen, desto kallare blir det under vintrarna. Bergen på norska västkusten har normalt en temperatur över noll i februari, medan Helsingfors i Finland normalt har en temperatur på $7-8{ }^{\circ} \mathrm{C}$ under noll samma månad.

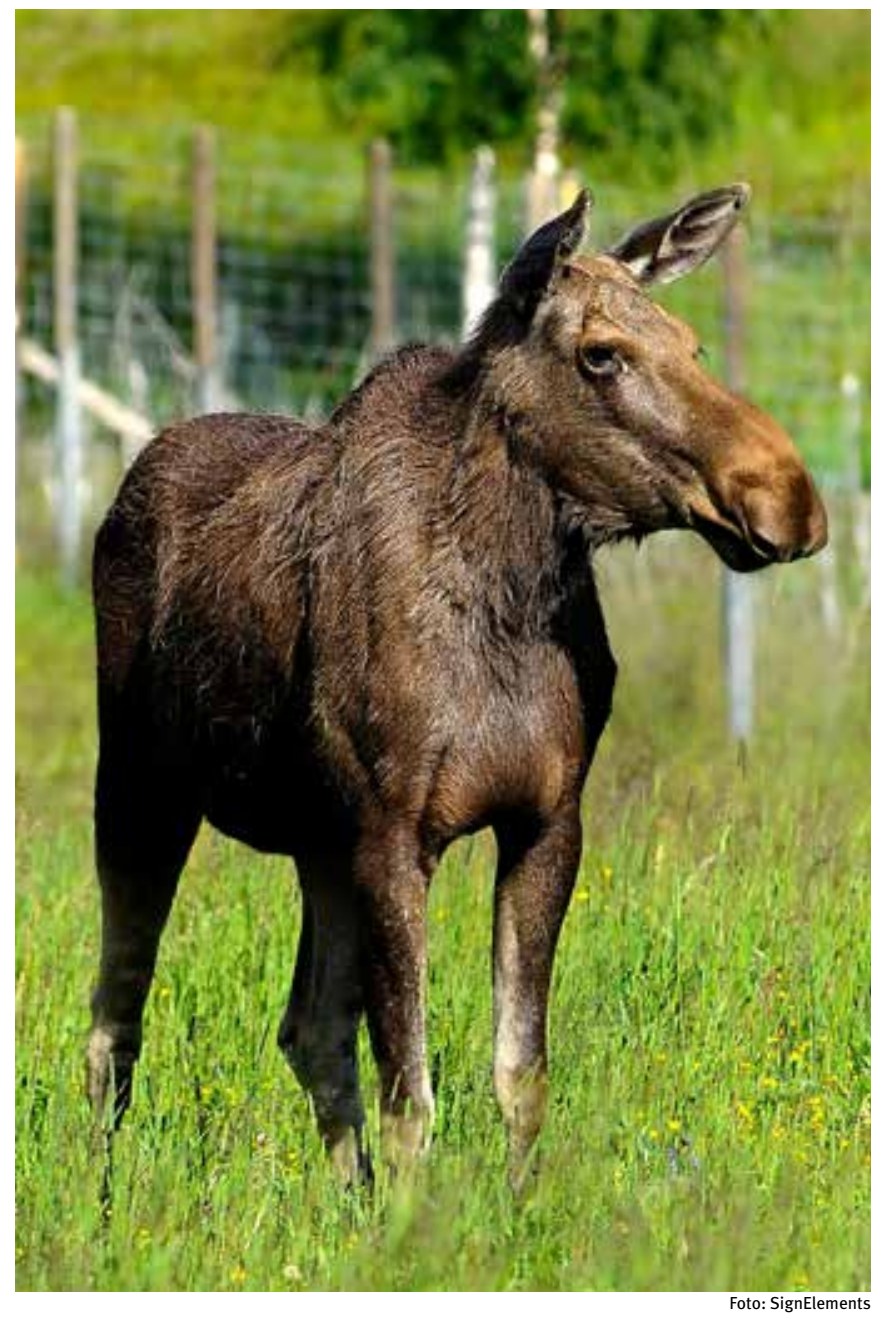




\section{Total area in the Nordic countries}

The Nordic countries comprise a total area of 3.5 million sq km. Even without Greenland and the Norwegian islands of Svalbard and Jan Mayen, the remaining part of the Nordic countries covers a vast area of 1.3 million sq km. This area is the size of Germany, France and Italy together. The Nordic region stretches over five time zones. To the east, the region borders on Russia, and in fair weather one can just make out the Canadian coastline to the west. To the south, its neighbours are Germany and Poland, and to the north: the Arctic Ocean.

However, with a population of only 26 million, the region has one of the lowest population densities in the world. The low density is partly due to the fact that large parts of the Nordic countries are marginal areas, where nature puts limitations on settlement. Denmark (excluding the Faroe Islands and Greenland) has the highest population density in the Nordic countries with 130 people per sq km and, thus, differs significantly from the other Nordic countries in this respect. In four out of five Nordic countries, around 20 per cent of the population is to be found in the vicinity of the respective capitals. In Iceland it is more than 60 per cent.
Total areal i Norden

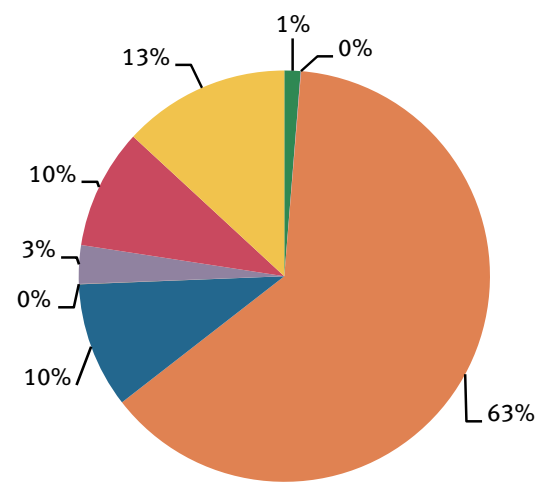

Denmark - $1 \%$ a Faroe Islands $<0.5 \%$ - Greenland $-63 \%$ - Finland $-10 \%$ Åland $<0.5 \%$ - Iceland - 3\% - Norway - $10 \%$ Sweden $-13 \%$ 政 of the Ministry of Agriculture and Forestry in Finland. Note: Norway: Area does not include Svalbard $(61022 \mathrm{sq} \mathrm{km})$ and Jan Mayen $(377 \mathrm{sq} \mathrm{k})$.
Not: Norge: Arealen inkluderar inte Svalbard $\left(61022 \mathrm{~km}^{2}\right)$ och Jan Mayen $\left(377 \mathrm{~km}^{2}\right)$.
Total areal i Norden

De nordiska länderna täcker en total areal av 3,5 miljoner km². Även utan Grönland, Svalbard och Jan Mayen utgör den resterande delen av Norden ett enormt område, nämligen 1,3 miljoner $\mathrm{km}^{2}$. Det är en yta av samma storlek som Tyskland, Frankrike och Italien tillsammans. Norden sträcker sig över fem tidszoner. I

öster gränsar Norden mot Ryssland, och i väster kan man skymta Kanadas kust i klart väder. I söder är Norden granne till Tyskland och Polen och i norr gränsar Norden till Ishavet.

Med en befolkning på endast 26 miljoner är regionen en av de minst tätbefolkade i världen. Detta beror huvudsakligen på att naturen sätter gränser för bosättning i de nordiska länderna. Danmark (exklusive Färöarna och Grönland) har den högsta befolkningstätheten i de nordiska länderna med 130 personer per km² och skiljer sig alltså väsentligt från de övriga nordiska länderna i detta avseende. I fyra av fem nordiska länder finns runt 20 procent av befolkningen i närheten av huvudstaden. När det gäller Island är det mer än 60 procent. 


\begin{tabular}{|c|c|c|c|c|c|c|c|c|c|}
\hline & Denmark & Faroe Islands & Greenland & Finland & Åland & Iceland & Norway & Sweden & \\
\hline $\begin{array}{l}\text { Total area, } \mathbf{s q ~} \mathbf{k m} \\
\text { Per cent }\end{array}$ & 43561 & 1396 & 2166086 & 338432 & 1580 & 103492 & 323771 & 447420 & $\begin{array}{r}\text { Total areal, } \mathbf{k m}^{2} \\
\text { Procent }\end{array}$ \\
\hline Total area & 100.0 & 100.0 & 100.0 & 100.0 & 100.0 & 100.0 & 100.0 & 100.0 & Total areal \\
\hline Arable land and gardens & 58.1 & 0.0 & 0.0 & 6.8 & 8.9 & 1.2 & 2.5 & 5.8 & Åkermark och trädgårdar \\
\hline Meadows and pastures & 8.2 & 0.0 & 0.0 & 0.1 & 3.4 & 16.9 & 0.5 & 1.0 & Ängsmark och betesmark \\
\hline Forests & 12.2 & 0.0 & 0.0 & 67.3 & 59.3 & 1.8 & 38.7 & 63.5 & Skog \\
\hline Other land area & 20.0 & 99.4 & 18.9 & 15.5 & 26.8 & 66.7 & 51.7 & 21.1 & Övrig landareal \\
\hline Lakes & 1.5 & 0.6 & 0.0 & 10.2 & 1.7 & 2.3 & 5.7 & 9.0 & Sjöar \\
\hline Icecap area & $\cdot$ & e & 81.1 & . & $\cdot$ & 10.2 & 0.9 & 0.1 & Glaciärer \\
\hline 1 January 2014 & & & & & & & & & 1 januari 2014 \\
\hline Population & 5627235 & 48228 & 56282 & 5451270 & 28666 & 325671 & 5109056 & 9644864 & Befolkning \\
\hline Inhabitants per sq km land area & 130.5 & 34.6 & 0.1 & 17.9 & 18.5 & 3.6 & 16.9 & 23.7 & Invånare per $\mathrm{km}^{2}$ landareal \\
\hline
\end{tabular}

Source: National statistical institutes, Finnish Forest Research Institute and Information Centre of the Ministry of Agriculture and Forestry, Finland.

Note: Finland: IInludes Aland. Norway: Area does not include Svalbard $(61022 \mathrm{sq} \mathrm{km})$ and Jan Mayen $(377 \mathrm{sq} \mathrm{km})$.
Not: Finland: Inkluderar Äland. Norge: Arealen inkluderar inte Svalbard $\left(61022 \mathrm{~km}^{2}\right)$ och Jan Mayen $\left(377 \mathrm{~km}^{2}\right)$.

\section{Land use}

Climatic conditions and quality of land determine how the land is used. In densely populated Denmark there is hardly any wild nature left. Most of the scarce forests are plantations, and nearly 60 per cent of Denmark's total area is cultivated or zoned as gardens or parks. In the other Nordic countries, there is much wild nature left. Only up to 9 per cent of the land in the other Nordic countries is cultivated. Around 17 per cent of the land area in Iceland is used for permanent meadows and pastures, and both Finland and Norway as well as Sweden have large forest areas.

\section{Markanvändning}

Klimatförhållandena och jordmånen avgör hur marken används. I det tätbefolkade Danmark finns nästan ingen ursprunglig natur kvar. Det mesta av den sparsamt förekommande skogen är planterad och nästan 60 procent av hela Danmarks areal är uppodlad eller använd till trädgårdar och parker. I de andra nordiska länderna finns fortfarande mycket ursprunglig natur kvar. Endast upp till 9 procent av arealen är uppodlad. Omkring 17 procent av landarealen på Island används till permanent ängsmark och betesmark. Såväl Finland som Norge och Sverige har stora skogsarealer.
Did you know that ... since the beginning of the 1960s the forest cover in the Nordic countries has increased by 5 per cent.

Visste du att ... sedan början av 1960-talet har skogsarealen i Norden ökat med 5 procent.

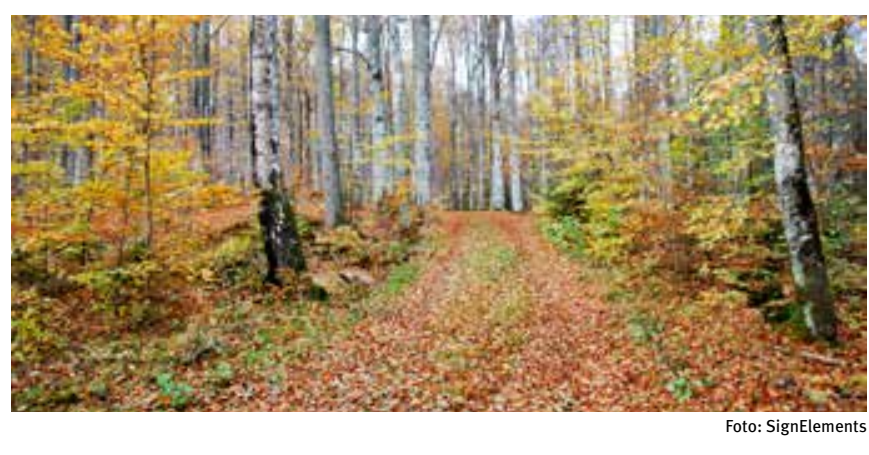




\section{Climate}

The climate in the Nordic countries is mainly influenced by their northern location, but remedied by the vicinity to the ocean and not the least to the Gulf Stream. Even far to the north the winters can be quite mild. The sea has a heavy influence on the weather in the western coastal zones of Iceland, Norway, Denmark and Sweden. The precipitation is high and snowcover during winters is rare. Summers are generally cool.

Finland, most of Sweden and the south-eastern part of Norway are influenced by the vast continent to the east which results in warm and long summers and clear and cold winters, often with snow. The precipitation is more scarce than in the western part of the Nordic countries.

Far to the north - north of the Polar Circle - the climate zone is Arctic with harsh winters and very short summers.

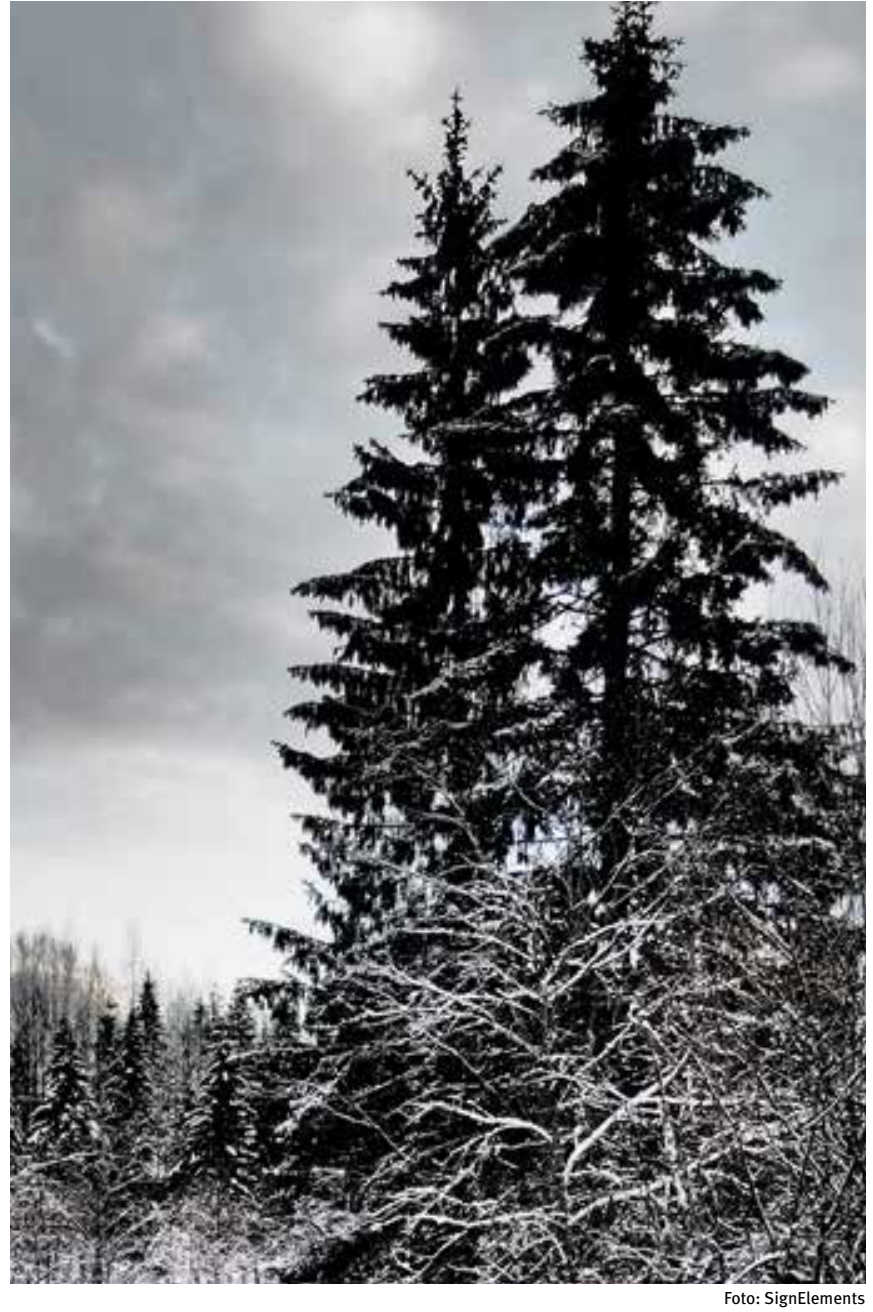

Klimat

Klimatet i Norden påverkas främst av det nordliga läget, men präglas också av närheten till havet och inte minst Golfströmmen. Även långt norrut kan vintrarna vara ganska milda. Havet har en stor inverkan på vädret i de västra kustområdena på Island, i Norge, Danmark och Sverige. Nederbörden är hög och snötäcke under vintrarna är sällsynt. Somrarna är i allmänhet svala.

Finland, största delen av Sverige och sydöstra delen av Norge påverkas av den stora kontinenten i öster vilket resulterar i varma och långa somrar och klara och kalla vintrar, ofta med snö. Nederbörd är mer sällsynt än i den västra delen av Norden.

Långt i norr - norr om polcirkeln - är det polarklimat som råder med hårda vintrar och mycket korta somrar. 


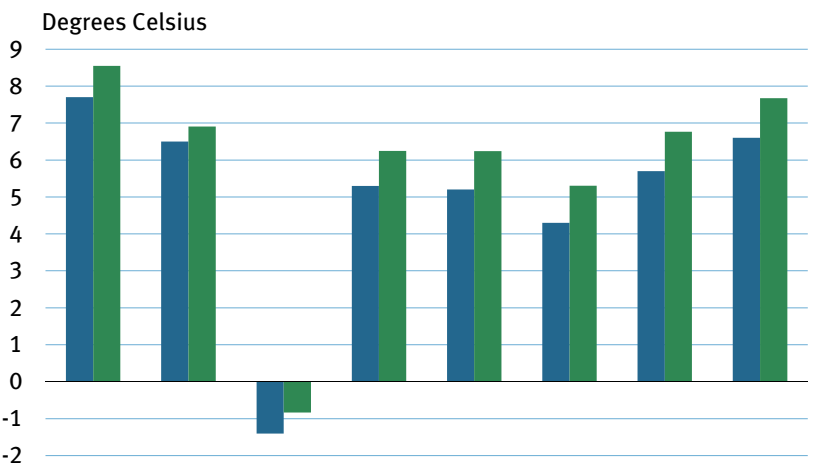

DK FO

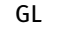

$\mathrm{Fl} \quad \mathrm{AX}$

IS NO

Average 1961-1990 므 Temp01 and Temp02 Source: National statistical institutes. Note.

Average 1990-2013

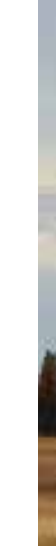

Temperatures in the Nordic countries

Temperaturer i de nordiska länderna
Normal 1961-1990

Degrees Celsius

Denmark, Copenhagen

Faroe Islands, Tórshavn

Greenland, Nuuk

Greenland, Tasiilaq

Finland, Helsink

Åland, Jomala

Iceland, Reykjavik

Iceland, Akureyri

Norway, Oslo

Norway, Troms $\varnothing$

Sweden, Stockholm

Sweden, Jokkmokk

\begin{tabular}{rr} 
\\
\hline 7.7 \\
6.5 \\
-1. \\
-1.7 \\
5.3 \\
5.2 \\
4.3 \\
3.2 \\
5.7 \\
2.5 \\
6.6 \\
-1. \\
\hline
\end{tabular}

$\begin{array}{rrr} & 2000 & 2013 \\ \mathbf{7 . 7} & 9.2 & 9.5 \\ \mathbf{6 . 5} & 6.6 & 7.1 \\ \mathbf{- 1 . 4} & -0.8 & -0.3 \\ \mathbf{- 1 . 7} & -0.5 & -0.3 \\ \mathbf{5 . 3} & 7.2 & 7.0 \\ \mathbf{5 . 2} & 6.9 & 6.6 \\ \mathbf{4 . 3} & 4.5 & 4.9 \\ \mathbf{3 . 2} & 4.2 & 4.0 \\ \mathbf{5 . 7} & 7.7 & 6.7 \\ \mathbf{2 . 5} & 3.2 & 4.0 \\ \mathbf{6 . 6} & 8.5 & 7.8 \\ \mathbf{- 1 . 1} & -0.9 & 0.3\end{array}$

马emp01 and Temp02

Source: The Danish Meteorological Institute (DMI), the Norwegian Meteorological Institute, the Swedish Meteorological and Hydrological Institute (SMHI) and national statistical institutes.
Table 1.2

2000

$32.9 \quad 31.6$

19.4

$\begin{array}{ll}15.9 & 20.1 \\ 17.2 & 17.3\end{array}$

28.6

23.0026 .4

$\begin{array}{ll}18.6 & 20.2 \\ 24.5 & 23.7\end{array}$

$26.5 \quad 29.0$

$22.6 \quad 28.3$

$27.3 \quad 29.3$

28.5
Lowest temperature

$20002013 \quad$ Grader Celsius

$-17.5-15.8$

$\begin{array}{ll}-17.1 & -17.9 \\ -18.0 & -22.6\end{array}$

$\begin{array}{rr}-18.0 & -22.6 \\ -11.8 & -25.0\end{array}$

$-11.8-12.8$

$\begin{array}{ll}-11.8 & -16.0\end{array}$

$\begin{array}{ll}-15.8 & -17.2\end{array}$

$-13.5 \quad-11.4$

$\begin{array}{ll}-13.0 & -16.2 \\ -33.9 & -33.1\end{array}$

Danmark, Köpenhamn

Färöarna, Tórshavn

Grönland, Nuuk

Grönland, Tasiilaq

Finland, Helsingfors

Åland, Jomala

Island, Reykjavik

Island, Akureyri

Norge, Oslo

Norge, Troms $\varnothing$

Sverige, Stockholm

Sverige, Jokkmokk

$-19.3 \quad-10.6$

$\begin{array}{ll}-6.0 & -6.3 \\ -17.5 & -15.8\end{array}$
Highest temperature 


\section{Global warming}

Carbon dioxide is the greenhouse gas with the greatest overall impact on the earth's energy balance. According to the Kyoto

Protocol, which forms the basis for an international agreement on greenhouse gas emissions, the industrial countries are to ensure jointly that during the period from 2008-2012, the overall emission of greenhouse gases is reduced to at least 5 per cent below 1990 levels. The EU nations have decided that 20 per cent of energy consumption in 2020 must come from renewable energy while reducing greenhouse gases by 20 per cent compared to 1990 levels. In addition, it was introduced as an indicative target to increase energy efficiency by 20 per cent. Some nations have implemented even more ambitious targets set in the Copenhagen Accord, where the nations could state their own individual goals. Norway, for example, intends to reduce carbon emissions by 30 per cent below 1990 levels by 2020 .

\section{Global uppvärmning}

Koldioxid är den växthusgas som har störst total effekt på jordens energibalans. Enligt Kyotoprotokollet, som utgör basen för ett internationellt avtal om utsläpp av växthusgaser, skall industriländerna gemensamt svara för att de totala utsläppen av växthusgaser i världen minskas till minst 5 procent under 1990 års nivåer under tiden 2008-2012. EU-länderna har beslutat att 20 procent av energiförbrukningen år 2020 skall komma från förnybar energi och att samtidigt minska växthusgaserna med 20 procent jämfört med 1990 års nivåer. Dessutom införde man ett vägledande mål att öka energieffektiviteten med 20 procent. Vissa länder har satt upp ännu mer ambitiösa mål som faststältts i Köpenhamn Accord, där nationerna kunde uppge sina egna individuella mål. Norge, till exempel, har för avsikt att minska koldioxidutsläppen med 30 procent under 1990 års nivåer fram till 2020.

Emissions of greenhouse gases. 2012 Utsläpp av växthusgaser

\begin{tabular}{lrrrrrr} 
& Denmark & Finland & Iceland & Norway & Sweden & \\
\hline 1 ooo tonnes $\mathrm{CO}_{2}$-equivalents & & & & & & $\mathrm{CO}_{2}$-ekvivalenter, 1 ooo ton \\
\hline Total greenhouse gases & $\mathbf{5 2 2 4 8}$ & $\mathbf{6 0 9 6 6}$ & $\mathbf{4 4 6 8}$ & $\mathbf{5 2 7 3 3}$ & $\mathbf{5 7 6 0 4}$ & Växthusgaser totalt \\
$\mathrm{CO}_{2}$ (carbon dioxide) & 39134 & 50733 & 3224 & 44101 & 45710 & $\mathrm{CO}_{2}$ (koldioxid) \\
$\mathrm{CH}_{4}$ (methane) & 5503 & 4083 & 457 & 4227 & 4804 & $\mathrm{CH}_{4}($ metan) \\
$\mathrm{N}_{2} \mathrm{O}$ (nitrous oxide) & 5968 & 5185 & 458 & 3200 & 6191 & $\mathrm{~N}_{2} \mathrm{O}(\mathrm{dikväveoxid)}$ \\
$\mathrm{HFC}$ (hydrofluorocarbons) & 664 & 926 & 144 & 972 & 775 & $\mathrm{HFC}($ fluorkolväte) \\
$\mathrm{PFC}$ (perfluorocarbons) & 9 & 2 & 80 & 172 & 69 & $\mathrm{PFC}($ perfluor-kol) \\
$\mathrm{SF}_{6}$ (sulphur hexafluoride) & 118 & 37 & 6 & 60 & 55 & $\mathrm{SF}_{6}$ (svavel hexafluorid) \\
\hline
\end{tabular}

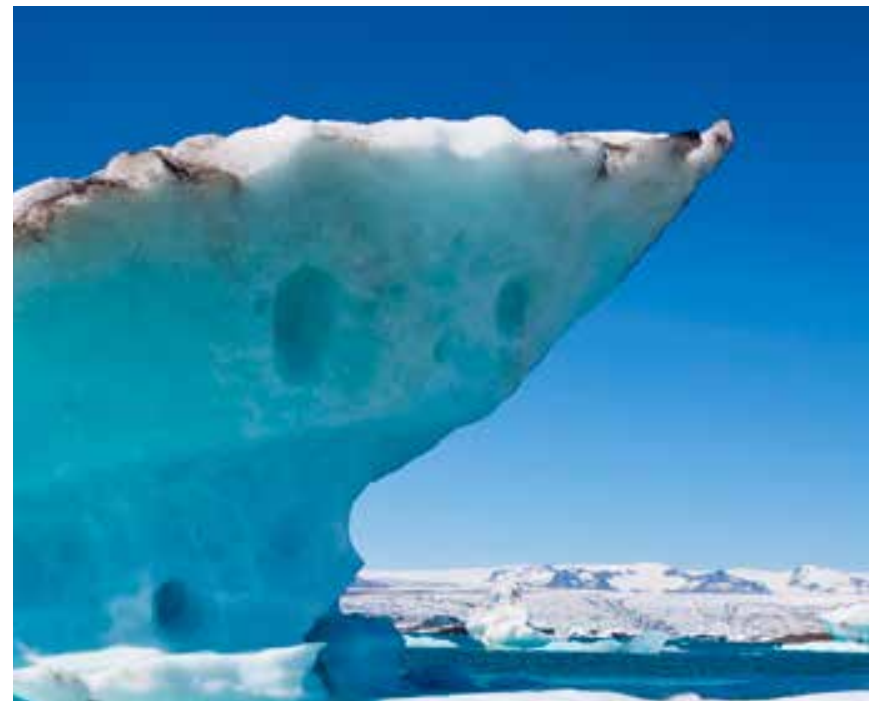

(sulphur hexafluoride)

S믈 Emis11

Note: Excluding LULUCF. 
Emissions of greenhouse gases

In Iceland and Norway the emissions of greenhouse gases in 2012 were still above the 1990 level. Finland was at the 1990 level in 2000, 2005 as well as 2008 and below in 2009 and 2011, but was above the 1990 level in 2010. Both in Finland and Denmark as well as Sweden the emissions were below the 1990 level in 2012 - in Denmark the level has been under the 1990 level since 2007, in Finland since 2011 and in Sweden since somewhere between 1998 and 1999. The three countries were between 15 and 25 per cent below the target in 2012 .

Utslåpp av våxthusgaser

På Island och i Norge låg utsläppen av växthusgaser år 2012 fortfarande över nivån för 1990. Finland låg på 1990 års nivå 2000, 2005 samt 2008 och under år 2009 och år 2011, men var över 1990-nivån under 2010. I såväl Danmark som Finland och Sverige låg utsläppen 2012 under nivån för 1990 - i Danmark har utsläppen varit under 1990 års nivå sedan 2007, i Finland sedan 2011 och i Sverige sedan någon gång mellan 1998 och 1999. Alla tre länder låg mellan 15 och 25 procent under 1990 års nivå år 2012.
Utsläpp av växthusgaser $\left(\mathrm{CO}_{2}\right.$-ekvivalenter)

Index 1990=100

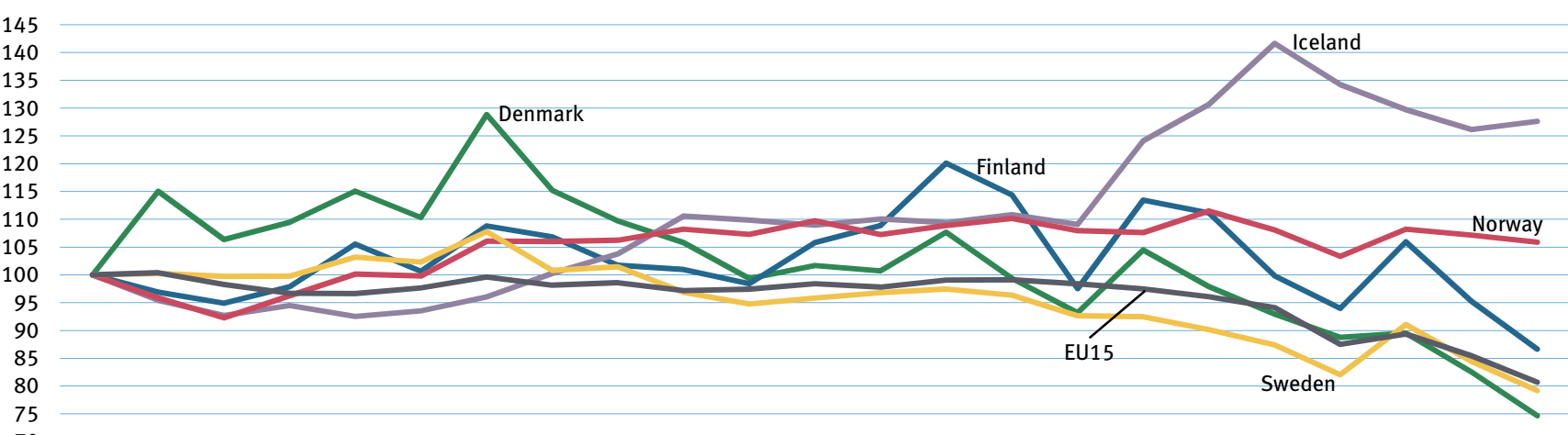

$\begin{array}{lllllllllllllllllllllll}1990 & 1991 & 1992 & 1993 & 1994 & 1995 & 1996 & 1997 & 1998 & 1999 & 2000 & 2001 & 2002 & 2003 & 2004 & 2005 & 2006 & 2007 & 2008 & 2009 & 2010 & 2011 & 2012\end{array}$

DEmis11

Note: EU15: The 15 members of the EU as per 1 January 1995.

Not: EU15: De 15 medlemsstaterna i Europeiska unionen per 1 januari 1995.

Greenhouse gas emissions per capita

Table 1.4

Utsläpp av växthusgaser per person

\begin{tabular}{|c|c|c|c|c|c|c|}
\hline & Denmark & Finland & Iceland & Norway & Sweden & \\
\hline $\mathrm{CO}_{2}$-equivalents, tonnes & & & & & & $\mathrm{CO}_{2}$-ekvivalenter, ton \\
\hline 1990 & 13.6 & 14.1 & 13.7 & 11.7 & 8.5 & 1990 \\
\hline 2000 & 13.0 & 13.4 & 13.7 & 11.9 & 7.8 & 2000 \\
\hline 2012 & 9.4 & 11.3 & 13.9 & 10.5 & 6.1 & 2012 \\
\hline
\end{tabular}

트is11 and Popu0

Source: UNFCCC. 


\section{Environment and energy Miljo̊ och energi}

We have plenty of untouched nature, clean water and fresh air in the Nordic countries, but we must keep a close eye on the environment so that future generations will be able to enjoy this. In the Nordic countries, there is a long tradition of cooperating on natural and environmental issues.

Conservation, environmental care, maintenance of bio-diversity, the environment and health as well as sustainable consumption and production are all high on the agenda in the Nordic region.

Themes such as the environment and the economy are also important priorities. Consumers are entitled to safe, healthy foodstuffs and the best possible product information, e.g. through labelling initiatives such as the Nordic Ecolabel.

The Nordic region is one of the richest sources of energy in the world. Apart from the natural occurrence of fossil fuels such as oil and gas, the Nordic region has also great opportunities to exploit renewable energy sources such as water, wind, bioenergy and geothermal heat.

The Nordic countries work together to create frameworks for the development of effective, competitive, safe and sustainable energy systems.
Vi har gott om orörd natur, rent vatten och frisk luft i Norden, men vi måste hålla ett vaksamt öga på miljön om kommande generationer också ska kunna ha glädje av detta. I de nordiska länderna finns det en lång tradition av att samarbeta om naturoch miljöfrågor.

I samarbetet för insatser inom Norden står skydd av natur och miljö, bevarande av den biologiska mångfalden, miljö och hälsa samt hållbar konsumtion och produktion högt på dagordningen.

Teman som miljö och ekonomi är också väsentliga insatsområden. De nordiska konsumenterna skall tillförsäkras hälsosamma produkter och livsmedel samt ges bästa möjliga information härom, vilket bland annat sker genom den nordiska miljömärkningen, Svanen.

Få områden i världen är så rika på energikällor som Norden. Utöver naturliga förekomster av fossila bränslen som olja och gas har Norden också stora möjligheter att utnyttja förnybara energikällor som vatten, vind, bioenergi och jordvärme.

De nordiska länderna samarbetar för att skapa ramar för utveckling av effektiva, konkurrenskraftiga, säkra och hållbara energisystem.

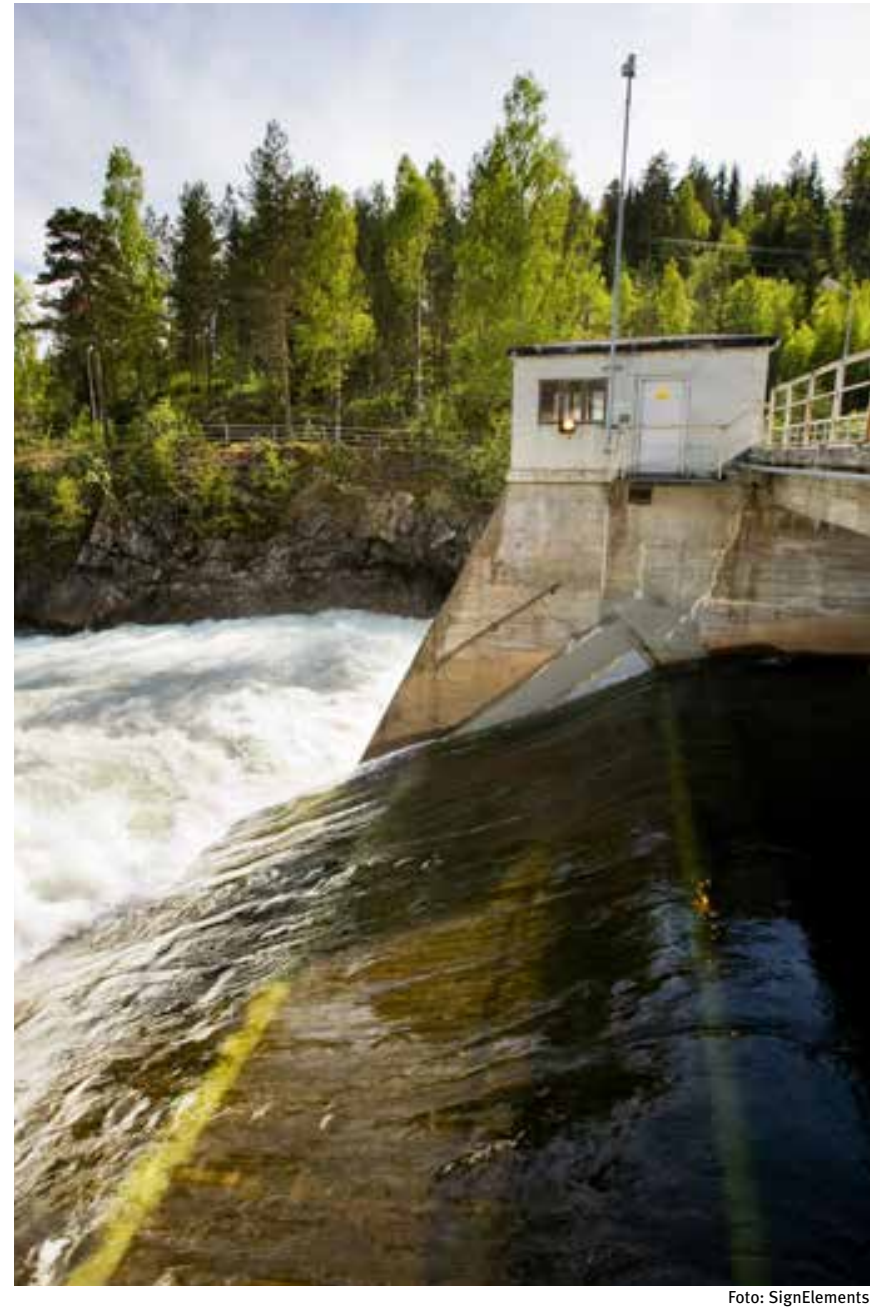

Foto: SignElements 


\section{Acidification}

The acidification of water and soil results from the emission of sulphur oxides $\left(\mathrm{SO}_{x}\right)$, nitrogen oxides $\left(\mathrm{NO}_{x}\right)$ and ammonia $\left(\mathrm{NH}_{3}\right)$. Emissions of these compounds stem primarily from the combustion of fossil fuels and emissions from farms with animals. Acidification can lead to forest dieback and harm to animals and vegetation in water areas. Acidification can also damage buildings and monuments. The quality of soil and vegetation determines the magnitude of the impact, as the presence of lime, in particular, may reduce or neutralise the impact of acidification.

The emission of sulphur oxides has been heavily reduced in most of the Nordic countries from the early 1980 s to the end of the 1990s. There has also been a reduction in the emission of nitrogen oxides but not to the same degree. There is a great presence of lime in soil and in water areas in Denmark, which neutralises the effect of acidification. The critical load is not exceeded anywhere in Iceland and acidification is not a problem. The Swedish and Norwegian nature, which is lime-deficient, is to a different extent vulnerable to acidification of soil, lakes and watercourses. In relation to the land area, Denmark has by far the highest emission of acidifying substances - however, international goals for emissions are nearly or already met.

Försurning

Försurningen av vatten och jord beror på utsläpp av svaveloxider ( $\left.\mathrm{SO}_{x}\right)$, kväveoxider $\left(\mathrm{NO}_{x}\right)$ och ammoniak $\left(\mathrm{NH}_{3}\right)$. Utsläppen av dessa föreningar härrör i första hand från förbränningen av fossila bränslen och utsläpp från jordbruk med boskap. Försurningen kan leda till att skogen dör och att djur och vegetation i vattenområden skadas, liksom byggnader och monument. Jord månen och vegetationens egenskaper är avgörande för skadornas omfattning, eftersom förekomsten av i synnerhet kalk kan minska eller neutralisera effekten av försurningen.

Emissions of acidifying substances. 2012

Utsläpp av försurande ämnen

$$
\text { Kg PAE per sq km }
$$

120

100

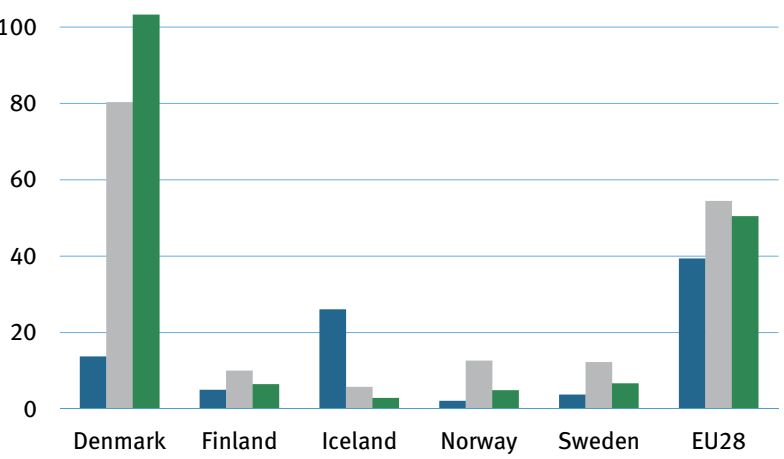

$\because \mathrm{SO} \quad \square \mathrm{NO}_{\mathrm{x}} \quad \square \mathrm{NH}_{3}$
Figure 2.1

Utsläppen av svaveloxid har minskat kraftigt i de flesta nordiska länderna från början av 80-talet till slutet av 90-talet. Även utsläppen av kväveoxider har minskat men inte i samma utsträckning. I Danmark finns mycket kalk i jorden och vattnet vilket motverkar försurning. Den kritiska belastningen överskrids inte någonstans på Island, och försurning är inte ett problem. Den kalkfattiga svenska och norska naturen är sårbar på ett helt annat sätt genom försurningen av jord, sjöar och vattendrag. I förhållande till landarealens storlek har Danmark de klart största utsläppen av försurande ämnen - internationella mål för utsläpp har dock nästan eller redan uppnåtts. 


\section{Fertilizers}

Animal and crop production in the agricultural sector involves the use of both manure and commercial fertilizers. This adds nitrogen $(\mathrm{N})$, phosphorus $(\mathrm{P})$ and potassium $(\mathrm{K})$, which are the main ingredients in commercial fertilizers, to the soil. Parts of the nitrogen and phosphorus and, to a lesser extent, potassium are not absorbed by plants but are washed out of the soil and taken to the sea by water runoffs. In particular, the release of nitrogen can lead to an unwanted algae growth, which is harmfu to the marine environment. The following measures are taken to limit the runoff of soil nutrients: better management of the use of fertilizers, better cultivation systems and technical facilities.

The consumption of commercial fertilizers affecting the environment has generally declined over the last twenty years.

\section{Gödningsmede}

Inom boskapsuppfödning och produktion av grödor i jordbrukssektorn används både naturgödsel och konstgödsel. Detta tillför jorden kväve (N), fosfor ( $\mathrm{P}$ ) och kalium (K), som är de aktiva huvudingredienserna $i$ konstgödsel. En del av kvävet och fosforn och en mindre del av kaliumet absorberas inte av växterna utan urlakas ur jorden och förs via vattendragen till havet. Särskilt utsläppen av kväve kan leda till oönskad algtillväxt som är skadlig för den marina miljön. Följande åtgärder har vidtagits för att begränsa avrinningen av näringsämnen $\mathrm{i}$ jorden: mer effektiv användning av gödsel, bättre odlingsmetoder samt tekniska åtgärder.

Användningen av konstgödsel med miljöeffekter har allmänt sett minskat under de senaste tjugo åren.

Consumption of commercial fertilizers. 2012/2013

Table 2.1 Användning av handelsgödsel

\begin{tabular}{lrrrrrrr} 
& Denmark & Finland & Åland & Iceland & Norway & Sweden \\
\hline 1000 tonnes & & & & & & & 1000 ton \\
Nitrogen (N) & 193.6 & 138.1 & 0.7 & 11.6 & 97.0 & 161.1 & Kväve (N) \\
Phosphorus (P) & 12.3 & 11.2 & 0.1 & 1.6 & 8.6 & 11.8 & Fosfor (P) \\
Potassium (K) & 46.2 & 30.5 & 0.3 & 2.7 & 33.0 & 23.2 & Kalium (K) \\
Kg per ha arable land & & & & & & & Kg per ha åkermark \\
Nitrogen (N) & 76.4 & 61.1 & 50.0 & 89.9 & 120.1 & 61.8 & Kväve (N) \\
Phosphorus (P) & 4.9 & 5.0 & 7.1 & 12.4 & 10.6 & 4.5 & Fosfor (P) \\
Potassium (K) & 18.2 & 13.5 & 21.4 & 20.9 & 40.9 & 8.9 & Kalium (K) \\
\hline
\end{tabular}

므 Ferto 1 and Area02

Source: National statistical institutes and Information Centre of the Ministry of Agriculture and Forestry, Finland. Note: Finland: Excl. forest fertilizers. Aland: 2011/2012 data.

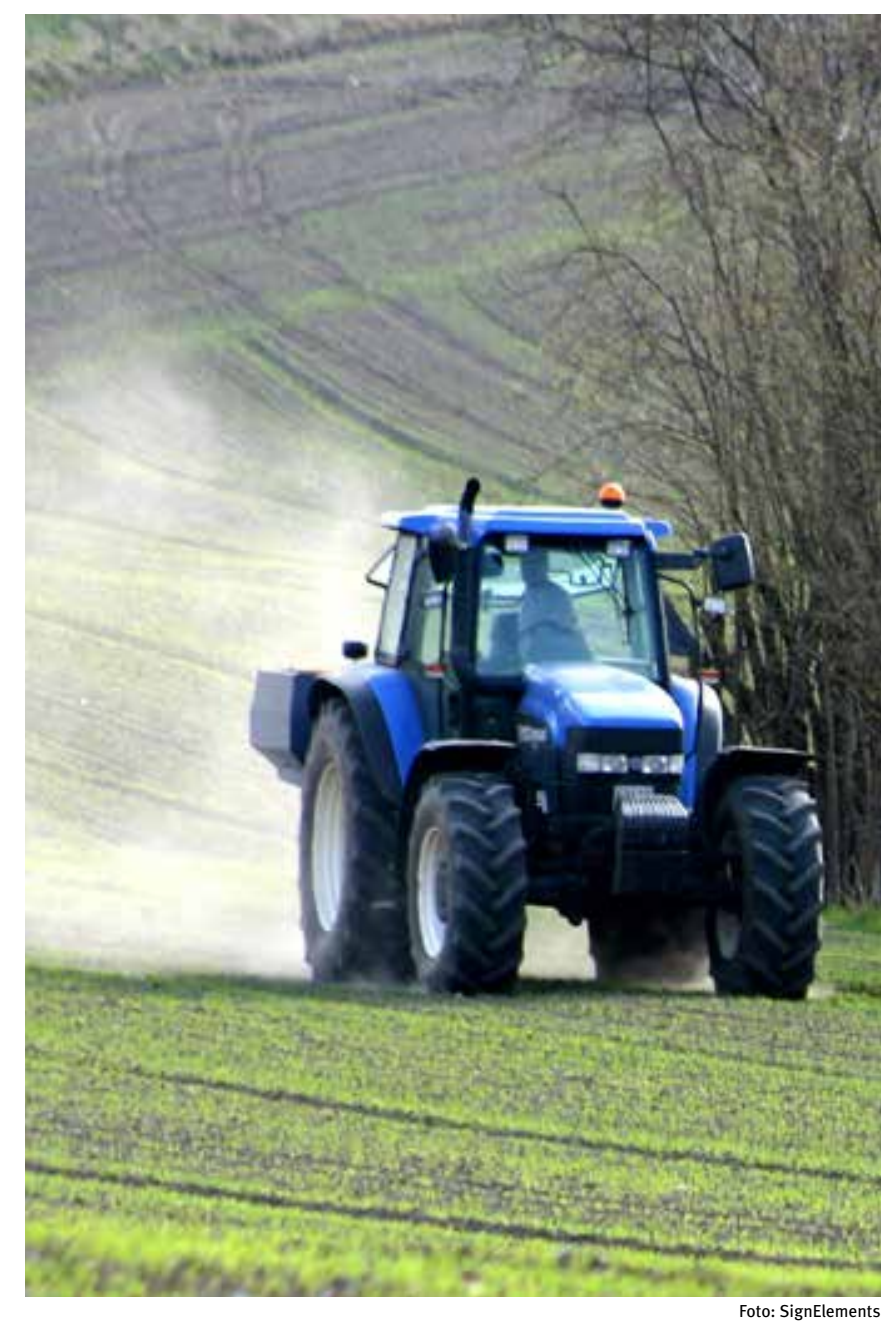

30 Environment and energy · Miljö och energi 


\section{Pesticides}

Pesticides are chemical products used primarily in the agricultural sector to fight weeds, fungi and insects. Pesticides can harm environmental conditions for humans, wild animals, plants and insects. Pesticides also accumulate in lakes and water streams, causing pollution.

Pesticides are divided into three different groups: herbicides against weeds, fungicides against fungi, and insecticides against unwanted insects. In addition, growth regulators are used, for example, to control the length of the straw in grain. There are major year-to-year variations in pesticide application, based on weather and other factors - for example, changes in what is cultivated.

The total amount of pesticides used in the Nordic countries has been cut almost in half since 1985 . Since the 1980 s, inorganic fungicidal compounds with application rates of several tens of kilograms per hectare have been replaced by more active organic compounds with application rates of a few kilograms per hectare.
Bekämpningsmedel

Bekämpningsmedel är kemisk-tekniska produkter som huvudsakligen används inom jordbruket för att bekämpa ogräs, svamp och insekter. Bekämpningsmedel kan ha skadlig inverkan på levnadsvillkoren för människor, vilda djur, växter och insekter. Medlen kan också ackumuleras i och förorena sjöar och vattendrag.

Bekämpningsmedel kan indelas i tre olika grupper: ogräsmedel mot ogräs, svampmedel mot svamp och insektsmedel mot skadeinsekter. Dessutom används tillväxtreglerande medel, exempelvis för att kontrollera stjälkens längd på spannmål. Det finns stora skillnader i förbrukningen av bekämpningsmedel mellan olika år beroende på väder och andra faktorer, exempelvis förändringar beträffande de grödor man odlar.

Den totala förbrukningen av bekämpningsmedel i de nordiska länderna har nästan halverats sedan 1985. Sedan 80-talet har oorganiska svampmedel med förbrukningstal på åtskilliga tiotals kilo per hektar nu ersatts av organiska föreningar som är mer aktivt biologiska med förbrukningstal på några kilo per hektar.
Total consumption of pesticides Figure 2.2 Total förbrukning av bekämpningsmedel

$$
\text { Index } 2000=100
$$

300
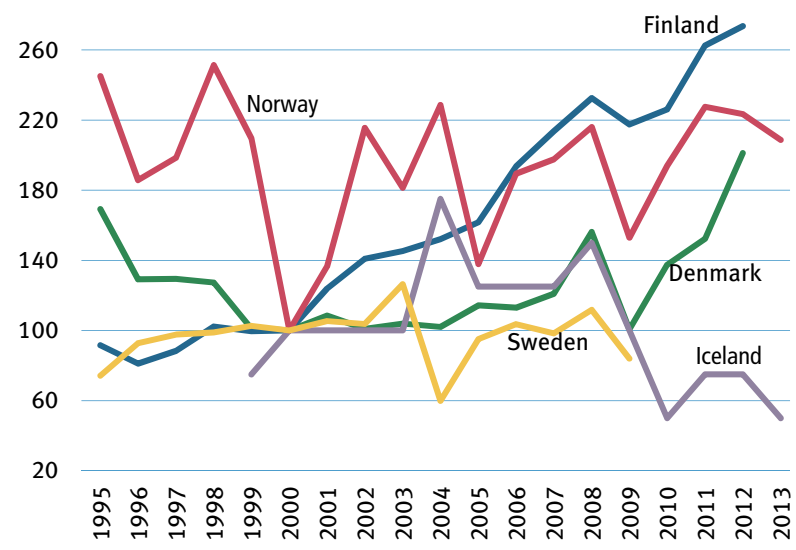
Ferto2

Source: National statistical institutes and Finnish Food Safety Authority Eviro. 
Organic farming area in per cent of total arable land Ekologisk jordbruksareal i procent av total åkermark

$$
\text { Per cent }
$$

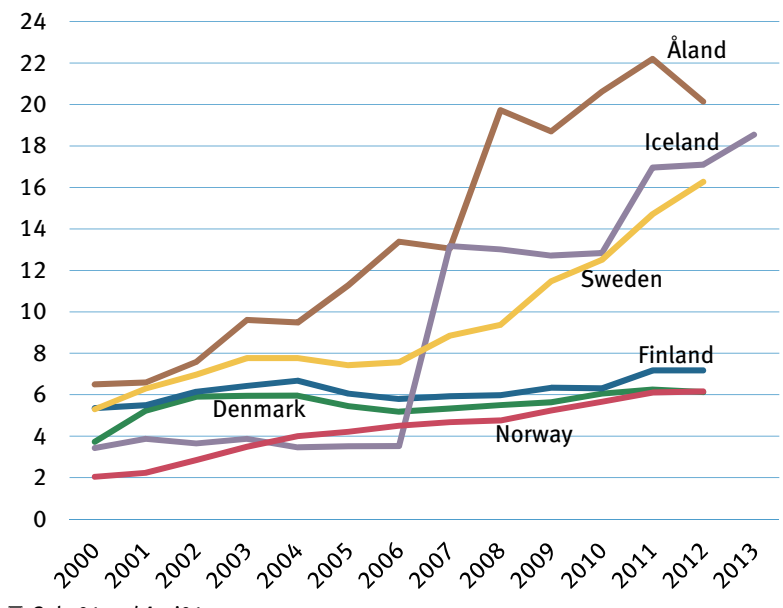

\section{Doeko01 and Agrio1}

Source: National statistical institutes and Information Centre of Agriculture and Forestry,

\section{Organic farming}

Organic farming is a form of agriculture that relies on the management of ecosystems and seeks to reduce or refrain from adding material. It is especially important not to add artificial substances, such as fertilizers or chemical pesticides. Organic farming tends to have lower intensity than conventional farming. It is an approach that looks at the big picture and intends to develop an ecosystem that can survive for a very long time (sustainable agriculture), a diversity of species (biodiversity) and ecosystem live in the soil (topsoil).

The organic farming area has risen in all of the Nordic countries since 2000. The organic farming area has risen remarkably in Iceland and Åland. Sweden has almost tripled the area from a little below 6 per cent to more than 16 per cent. Norway has also almost tripled the area from 2 to 6 per cent, while Finland and Denmark have had a more moderate growth.
Ekologiskt jordbruk

Ekologiskt jordbruk är en form av jordbruk som förlitar sig på förvaltande av ekosystem och strävar efter att minska eller helt avstå från att tillföra material. Särskilt viktigt är det att inte tillföra konstgjorda ämnen som handelsgödsel eller kemiska bekämpningsmedel. Ekologiskt jordbruk tenderar att ha lägre intensitet än konventionellt jordbruk. Det är ett förhållningssätt som ser till helheten och avser att åstadkomma ekosystem som kan fortleva mycket länge (hållbart jordbruk), en mångfald av arter (biodiversitet) och levande ekosystem i jorden (matjorden).

Det ekologiska jordbruket har ökat i alla nordiska länder sedan 2000. Det ekologiska jordbruket har ökat anmärkningsvärt på Island och Åland. Sverige har nästan tredubblat arealen från lite under 6 procent till drygt 16 procent. Norge har också tredubblat området för ekologiskt jordbruk från 2 till 6 procent, medan Finland och Danmark har haft en mer måttlig tillväxt.

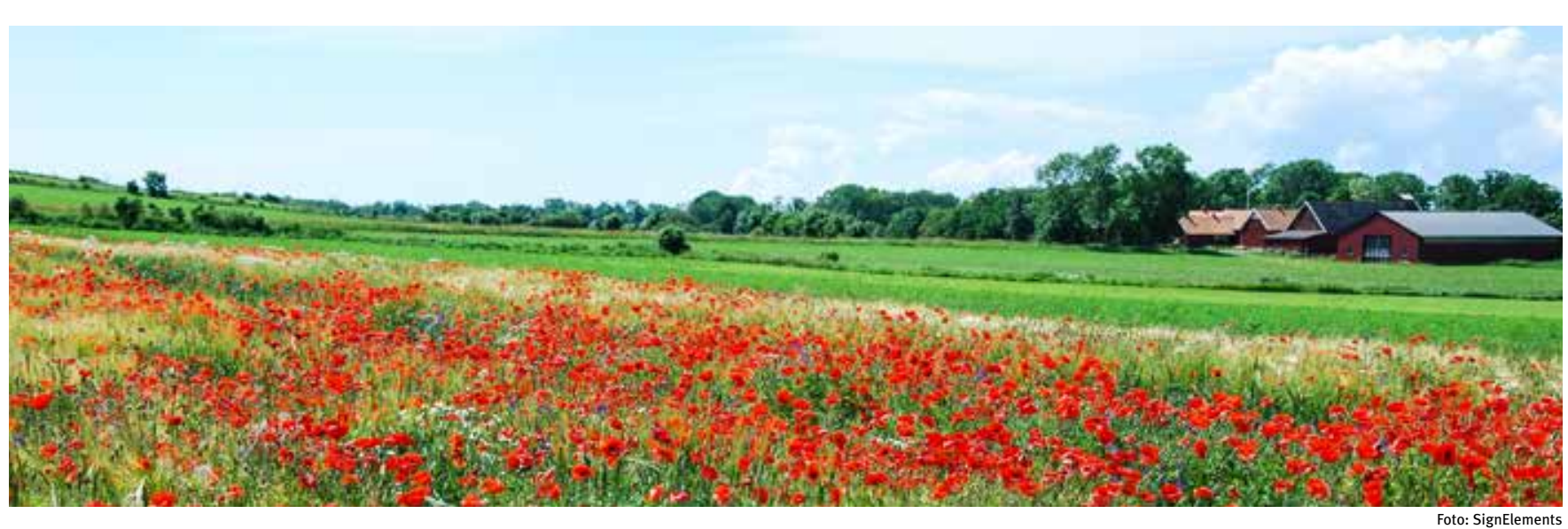




\section{Energy production}

Energy production and energy use have a major environmental impact. The environmental problem is not so much the production or use of energy per se as the fact that most of the energy use in the world stems from fossil fuels, which results in the emissions of $\mathrm{CO}_{2}$ (carbon dioxide), contributing to the greenhouse effect. However, electricity based on hydro and wind power does not give rise to the emission of $\mathrm{CO}_{2}$, and especially Iceland and Sweden, but also Finland and Norway, have a significant production of electricity based on hydro power. Geothermal energy production, which is the most importan source in Iceland, and nuclear power, which is produced in both Finland and in Sweden, do not give rise to the emission of $\mathrm{CO}_{2}$ either.

Indigenous energy production by country. 2012 Figure 2.4 Inhemsk energiproduktion efter land

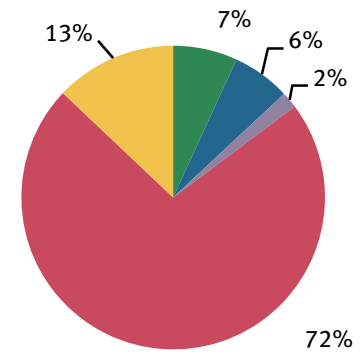

- Denmark

- Finland

- Iceland

- Norway

sweden

Figure 2.4

(n)
The indigenous production of energy in the Nordic countries has risen considerably over the last couple of decades - especially in Denmark and Norway due to oil deposits in the North Sea.

\section{Energiproduktion}

Energiproduktion och energianvändning har stor inverkan på miljön. Miljöproblemet är inte så mycket produktionen eller användningen av energi i sig som det faktum att huvuddelen av den energi som används i världen kommer från fossila bränslen som ger utsläpp av $\mathrm{CO}_{2}$ (koldioxid), vilket bidrar till växthuseffekten. Elektricitet baserad på vatten- och vindkraft genererar emellertid inga utsläpp av $\mathrm{CO}_{2}$ och särskilt Island och Sverige,

Indigenous energy production. 2012 Figure 2.5 Inhemsk energiproduktion

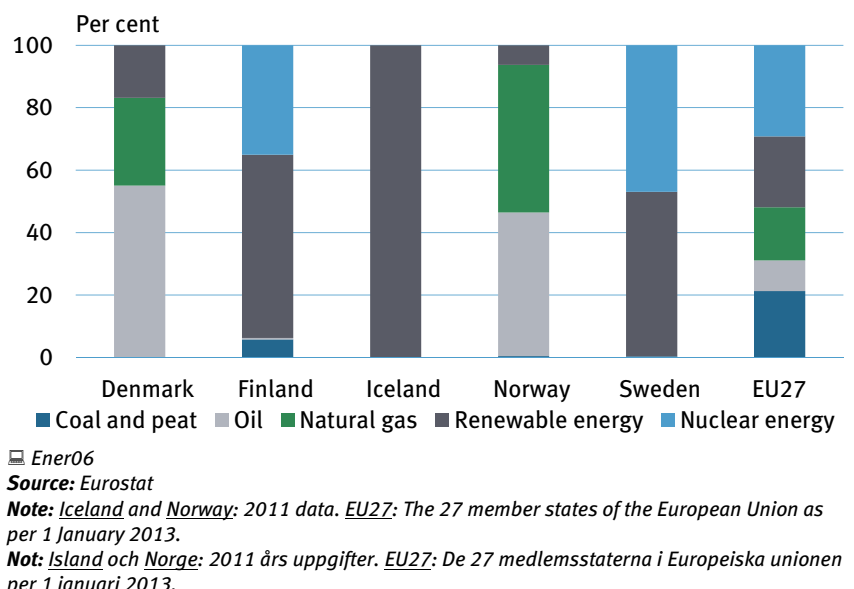

men även Finland och Norge, har en betydande elproduktion baserad på vattenkraft. Energiproduktion från geotermisk energi, som är dominerande på Island, samt kärnkraft, som produceras både Finland och Sverige, ger inte heller några utsläpp av $\mathrm{CO}_{2}$.

Den inhemska produktionen av energi i de nordiska länderna har ökat väsentligt under de senaste årtiondena - särskilt i Danmark och Norge på grund av oljedepåer i Nordsjön.

(1)




\section{Energy sources}

The most important energy sources in the Nordic countries measured in terms of energy supply in million toe (tonnes oil equivalent) are in order of importance: oil, solid fuels (e.g. coal and wood), nuclear power, hydro and geothermal power, solar energy and gas. In the EU the most important source of energy is also oil, but here gas comes in second.

Hydro and geothermal power and other renewable sources are major sources of energy in the Nordic countries, as compared to the EU countries. Particularly in Iceland and Norway, hydro and geothermal power constitute a major share of the overall energy supply. Denmark depends almost entirely on thermal power generated from coal, oil and gas. Iceland obtains a substantial part of its energy for heating from geothermal energy and depends almost entirely upon hydropower resources for its production of electricity.

Energikållor

De viktigaste energikällorna i de nordiska länderna räknat energitillskott i miljoner toe (tonnes oil equivalent, ekvivalenta oljeton) är i storleksordning: olja, fasta bränslen (exempelvis ko och ved), kärnkraft, vattenkraft, jordvärmeenergi, solkraft och gas. Inom EU är den viktigaste energikällan också olja, men här kommer gasen på andra plats.

Vattenkraft, jordvärmeenergi och andra hållbara energikällor ä mer betydande kraftkällor i de nordiska länderna än i EU-länderna. Särskilt på Island och i Norge utgör vattenkraft och jordvärmeenergi den största andelen av den totala energiförsörjningen. Danmark är nästan uteslutande beroende av termisk kraft genererad från kol, olja och gas. Island utvinner en väsentlig del av sin energi för uppvärmning från geotermisk energi och är nästan helt beroende av vattenkraftkällor för sin produktion av elektricitet.

Final consumption of energy. 2012 Slutlig energiförbrukning

$$
\text { Denmark Finland Iceland Norway Sweden }
$$

\begin{tabular}{lrrrrrr}
$\begin{array}{l}\text { Tonnes oil equivalents per person } \\
\text { Total }\end{array}$ & \multicolumn{2}{c}{} & & & & Ekvivalenta oljeton per person \\
Totalt
\end{tabular}

\section{믈 Ener10 and Popu02}

Source: Eurostat.

Norway: 2011 data.

Not: Island: 2006 års uppgifter. Norge: 2011 års uppgifter.

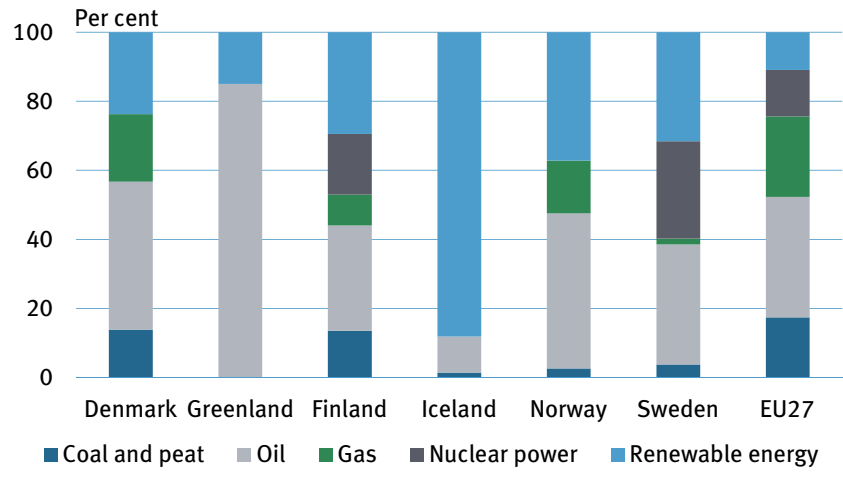

Ener05

\section{Source: Eurostat.}

Note: Iceland and Norway: 2011 data. EU27: The 27 member states of the European Union as

Not: Island och Norge: 2011 års uppgifter. EU27: De 27 medlemsstaterna i Europeiska unione per 1 januari 2013 .

Table 2.2
34 Environment and energy - Miljö och energi

Did you know that ... in 1960 nearly 90 per cent of the total production of electricity in Sweden stemmed from hydropower. In Finland it was almost 59 per cent.

Visste du att ... år 1960 kom nästan 90 procent av elproduktionen i Sverige från vattenkraft och i Finland var motsvarande siffra nästan 59 procent. 


\section{Population \\ Befolkning}

At the beginning of the 20th century, almost 12 million people lived in the Nordic countries. Today, the population has in-

creased to more than 26 million people - more than a doubling. The strongest growth is seen in Greenland, where the population has multiplied by almost five, from 12000 to 56000 people. In Iceland the increase has gone from 78000 to 326000 people. The population on the Faroe Islands has more than tripled, from 15000 to 48000 people. The Swedish and Ålandic populations are the only ones that have not at least doubled.
I början av 1900-talet bodde nästan 12 miljoner människor i de nordiska länderna. I dag har befolkningen ökat till mer än 26 miljoner människor - mer än en fördubbling. Den snabbaste tillväxten har skett på Grönland, där befolkningen nästan har femdubblats, från 12000 till 56000 personer. På Island har folkmängden ökat från 78000 till 326000 . Befolkningen på Färöarna har mer än tredubblats med en ökning från 15000 til 48000 personer. Sverige och Åland är de enda länder där det inte skett minst en fördubbling av befolkningen.

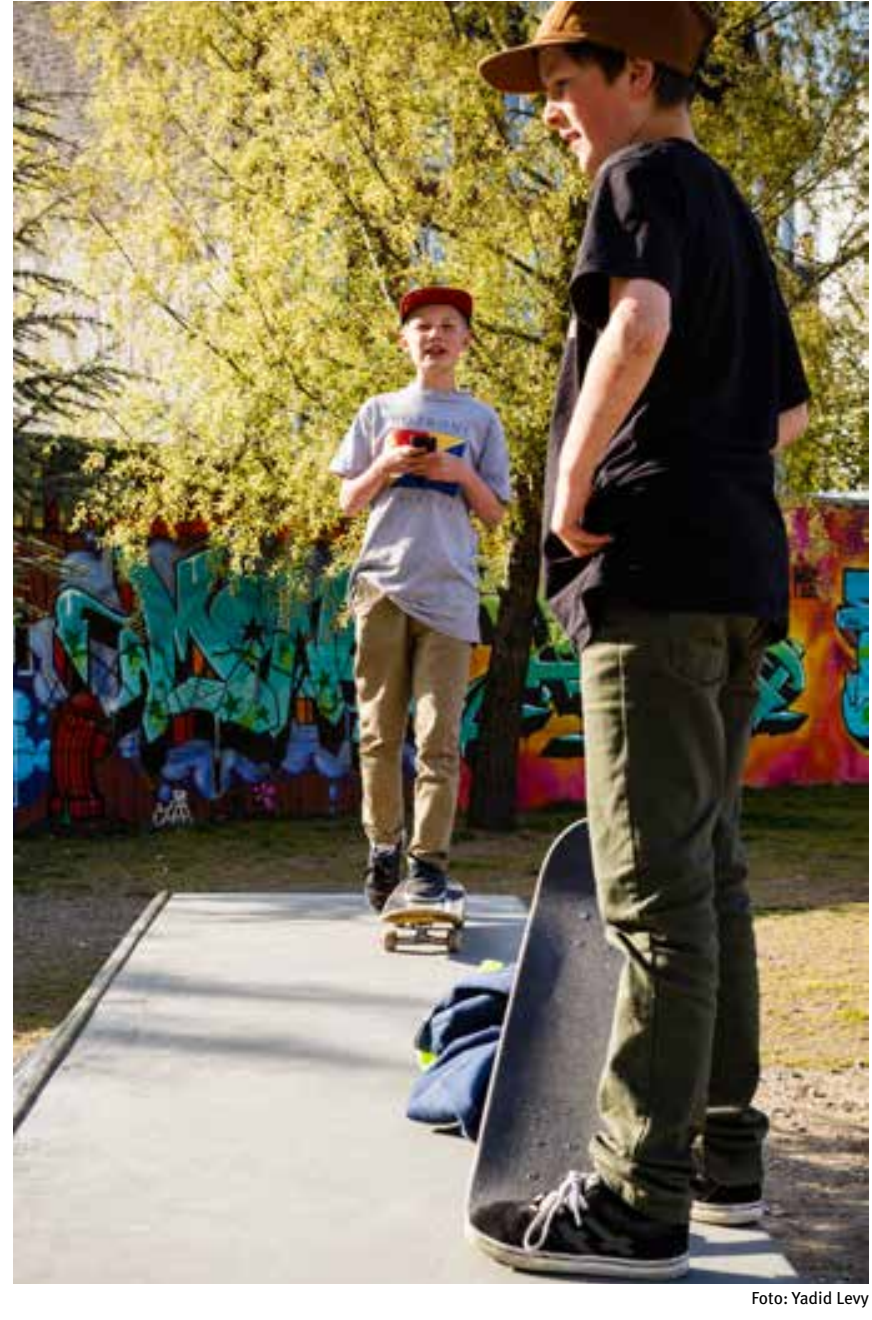

Population · Befolkning 
The Nordic population

Since 1990, the total population in the Nordic countries has increased by more than 3 million people (13 per cent) - the most in Iceland ( 28 per cent) and in Norway and Åland by close to 21 and 18 per cent respectively. Certain regions in Sweden, Norway and Finland have experienced a decline in the population, but at the national level, all the Nordic countries have experienced growth.

Compared to 2005, the Faroe Islands and Greenland have experienced a minor decline in the population. Iceland has also experienced shorter periods with a declining population.

Den nordiska befolkningen

Sedan 1990 har den totala folkmängden i de nordiska länderna ökat med mer än 3 miljoner invånare (13 procent) - mest på Island (28 procent) samt i Norge och på Åland med nästan 21 respektive 18 procent. Vissa regioner i Sverige, Norge och Finland har upplevt en befolkningsminskning, men på nationell nivå har det skett en ökning i hela Norden.

Jämfört med år 2005 har Färöarna och Grönland haft en mindre befolkningsminskning. Island har också upplevt kortare perioder med minskande befolkning.
Denmark Faroe Is. Greenland Finland Åland Iceland Norway Sweden Nordic total

\begin{tabular}{lllll}
\hline Persons & Denmark & Aland & Norway is. Geeland & Personer \\
\hline
\end{tabular}

Total

$\begin{array}{lllllllllll}1990 & 5135409 & 47770 & 55558 & 4974383 & 24231 & 253785 & 4233116 & 8527036 & 23227057 & 1990 \\ 1995 & 5215718 & 43644 & 55732 & 5098754 & 25158 & 266978 & 4348410 & 8816381 & 23845617 & 1995\end{array}$

$\begin{array}{lllllllllll}1995 & 5215718 & 43644 & 55732 & 5098754 & 25158 & 266978 & 4348410 & 8816381 & 23845617 & 1995 \\ 2000 & 5330020 & 45353 & 56107 & 5171302 & 25706 & 279049 & 4478497 & 8861426 & 24221754 & 2000\end{array}$

$\begin{array}{lllllllllll}2005 & 5411405 & 48337 & 56969 & 5236611 & 26530 & 293577 & 4606363 & 9011392 & 24664654 & 2005\end{array}$

$\begin{array}{lllllllllll}2010 & 5534738 & 48568 & 56452 & 5351427 & 27734 & 317630 & 4858199 & 9340682 & 25507696 & 2010 \\ 2014 & \mathbf{5 6 2 7 2 3 5} & \mathbf{4 8 1 9 7} & \mathbf{5 6 2 8 2} & \mathbf{5 4 5 1 2 7 0} & \mathbf{2 8 6 6 6} & \mathbf{3 2 5} 671 & \mathbf{5 1 0 9 0 5 6} & \mathbf{9 6 4 4 8 6 4} & \mathbf{2 6 2 6 2 5 7 5} & \mathbf{2 0 1 4}\end{array}$

$\begin{array}{lllllllllll} & 56282 & 5451270 & 28666 & 325671 & 5109056 & 9644864 & 26262575 & 2014\end{array}$

$\begin{array}{llllllllll}\text { Men } & 2530597 & 24915 & 30057 & 2412760 & 11900 & 127432 & 2093280 & 4212080 & 11431121\end{array}$

$\begin{array}{lllllllllll}1990 & 2530597 & 24915 & 30057 & 2412760 & 11900 & 127432 & 2093280 & 4212080 & 11431121 & 1990 \\ 1995 & 2573324 & 22577 & 29706 & 2481649 & 12365 & 133891 & 2150257 & 4356254 & 11747658 & 1995\end{array}$

$\begin{array}{lllllllllll}1995 & 2573324 & 22577 & 29706 & 2481649 & 12365 & 133891 & 2150257 & 4356254 & 11747658 & 1995 \\ 2000 & 2634122 & 23464 & 29979 & 2523026 & 12639 & 139665 & 2217140 & 4380118 & 11947514 & 2000 \\ 2005 & 2677292 & 25116 & 30319 & 2562077 & 13102 & 147170 & 2284070 & 446631 & 12192355 & 2005\end{array}$

$\begin{array}{lllllllllll}2005 & 2677292 & 25116 & 30319 & 2562077 & 13102 & 147170 & 2284070 & 4466311 & 12192355 & 2005 \\ 2010 & 2743286 & 25248 & 29936 & 2625067 & 13807 & 159936 & 2426752 & 4649014 & 12659239 & 2010\end{array}$

$\begin{array}{lllllllllll}2010 & 2743286 & 25248 & 29936 & 2625067 & 13807 & 159936 & 2426752 & 4649014 & 12659239 & 2010 \\ \mathbf{2 0 1 4} & \mathbf{2 7 9 2 2 7 9} & \mathbf{2 5 0 1 9} & \mathbf{2 9 7 3 0} & \mathbf{2 6 8 0 3 6 4} & \mathbf{1 4 3 0 2} & \mathbf{1 6 3 3 1 8} & \mathbf{2 5 6 7 4 3 4} & \mathbf{4 8 1 4 3 5 7} & \mathbf{1 3 0 7 2 5 0 1} & \mathbf{2 0 1 4}\end{array}$

Women

$\begin{array}{lllll}2604812 & 22855 & 25501 & 2561623 & 19\end{array}$

$\begin{array}{lllllllllll}1990 & 2604812 & 22855 & 25501 & 2561623 & 12331 & 126353 & 2139836 & 4314956 & 11795936 & 1990 \\ 1995 & 2642394 & 21067 & 26026 & 2617105 & 12793 & 133087 & 2198153 & 4460127 & 12097959 & 1995\end{array}$

$\begin{array}{lllllllllll}1995 & 2642394 & 21067 & 26026 & 2617105 & 12793 & 133087 & 2198153 & 4460127 & 12097959 & 1995 \\ 2000 & 2695898 & 21889 & 26128 & 2648276 & 13067 & 139384 & 2261357 & 4481308 & 12274240 & 2000\end{array}$

$\begin{array}{lllllllllll}2000 & 2695898 & 21889 & 26128 & 2648276 & 13067 & 139384 & 2261357 & 4481308 & 12274240 & 2000 \\ 2005 & 2734113 & 23221 & 26650 & 2674534 & 13428 & 146407 & 2322293 & 4545081 & 12472299 & 2005\end{array}$

$\begin{array}{lllllllllll}2005 & 2734113 & 23221 & 26650 & 2674534 & 13428 & 146407 & 2322293 & 4545081 & 12472299 & 2005 \\ 2010 & 2791452 & 23320 & 26516 & 2726360 & 13927 & 157694 & 2431447 & 4691668 & 12848457 & 2010\end{array}$

\begin{tabular}{lllllllllll}
2010 & 2791452 & 23320 & 26516 & 2726360 & 13927 & 157694 & 2431447 & 4691668 & 12848457 & 2010 \\
$\mathbf{2 0 1 4}$ & $\mathbf{2 8 3 4 9 5 6}$ & $\mathbf{2 3 1 7 8}$ & $\mathbf{2 6 5 5 2}$ & $\mathbf{2 7 7 0 9 0 6}$ & $\mathbf{1 4 3 6 4}$ & $\mathbf{1 6 2 3 5 3}$ & $\mathbf{2 5 4 1 6 2 2}$ & $\mathbf{4 8 3 0 5 0 7}$ & $\mathbf{1 3 1 9 0 0 7 4}$ & $\mathbf{2 0 1 4}$ \\
\hline Popu01 & & & & & & &
\end{tabular}

Source: National statistical institutes.

Note: Finland: Includes Äland. Faroe I Ilands: 2014 refers to 2013.
Not: Finland: Inkluderar Åland. Färöarna: 2014 avser 2013 ärs uppgifter. 


\section{Life expectancy}

By measuring the mortality rate, life expectancy at birth can be calculated. This measure indicates how many years a newborn is expected to live, based on current patterns of mortality. As the mortality rate of men and women differs quite a bit (women tend to live longer), life expectancy is calculated separately for men and women.

Life expectancy is rising in all the Nordic countries. However, the levels vary greatly. Life expectancy for men in Greenland is 68.7 years (2012), compared to 80.8 years for men in Iceland. Women in Finland are expected to live the longest - close to 84 years.

Medellivslängd

Att mäta dödlighetsfrekvensen är ett sätt att beräkna medellivslängden för en nyfödd. Detta mått indikerar hur många år en nyfödd kan förvänta sig att leva baserat på nuvarande dödlighetsmönster. Eftersom dödlighetstalen skiljer sig en hel del mellan män och kvinnor (kvinnor tenderar att leva längre), beräknas medellivslängden separat för män och kvinnor.

Medellivslängden ökar i alla nordiska länder. Den varierar emellertid kraftigt. Medellivslängden för män på Grönland är 68,7 år (år 2012) jämfört med 80,8 år för män på Island. Kvinnor i Finland kan förvänta sig att leva längst - nästan 84 år.

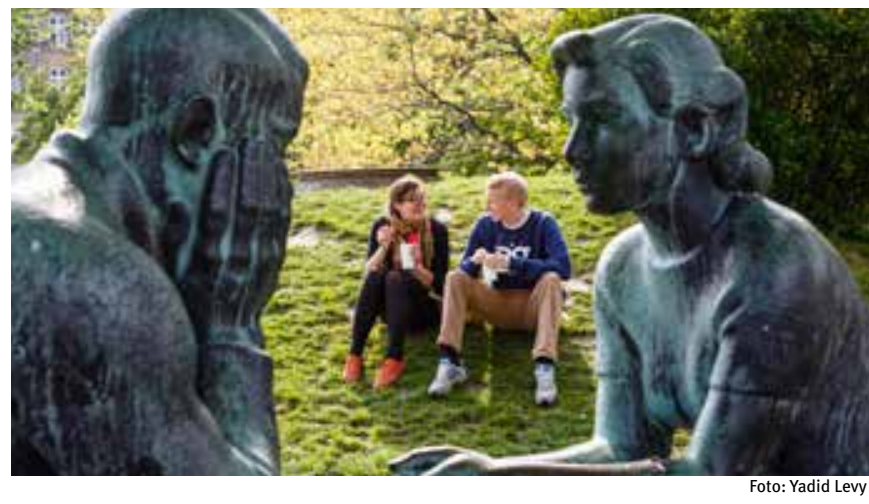

Life expectancy at birth

Table 3.2

Förväntad medellivslängd för nyfödda

\begin{tabular}{|c|c|c|c|c|c|c|c|c|c|}
\hline & Denmark & Faroe Is. & Greenland & Finland & Åland & Iceland & Norway & Sweden & \\
\hline Persons & & & & & & & & & Personer \\
\hline Men & & & & & & & & & Män \\
\hline 1990 & 72.0 & 72.6 & 60.7 & 70.9 & 74.7 & 75.0 & 73.4 & 74.8 & 1990 \\
\hline 1995 & 72.6 & 73.9 & 62.3 & 72.8 & 75.1 & 76.5 & 74.8 & 76.2 & 1995 \\
\hline 2000 & 74.3 & 75.9 & 62.8 & 74.1 & 78.5 & 77.6 & 76.0 & 77.4 & 2000 \\
\hline 2005 & 75.6 & 77.0 & 65.5 & 75.5 & 77.6 & 79.2 & 77.7 & 78.4 & 2005 \\
\hline 2010 & 77.1 & 78.4 & 67.9 & 76.7 & 80.1 & 79.7 & 78.9 & 79.5 & 2010 \\
\hline 2013 & 78.0 & 79.3 & 68.7 & 77.8 & 79.7 & 80.8 & 79.3 & 80.1 & 2013 \\
\hline Women & & & & & & & & & Kvinnor \\
\hline 1990 & 77.7 & 79.7 & 68.4 & 78.9 & 82.8 & 80.1 & 79.8 & 80.4 & 1990 \\
\hline 1995 & 77.8 & 80.9 & 68.3 & 80.2 & 81.1 & 80.6 & 80.8 & 81.5 & 1995 \\
\hline 2000 & 79.0 & 81.1 & 68.0 & 81.0 & 81.5 & 81.4 & 81.4 & 82.0 & 2000 \\
\hline 2005 & 80.2 & 81.8 & 70.9 & 82.3 & 83.6 & 83.1 & 82.5 & 82.8 & 2005 \\
\hline 2010 & 81.2 & 83.0 & 72.9 & 83.2 & 83.8 & 83.7 & 83.2 & 83.5 & 2010 \\
\hline 2013 & 81.9 & 83.4 & 73.5 & 83.8 & 83.2 & 83.7 & 83.6 & 83.7 & 2013 \\
\hline
\end{tabular}

口L Life01

Source: National statistical institutes.

Note: Finland: Includes Âland. Greenland and Åland: 2013 refers to 2012.

Not: Finland: Inkluderar Åland. Grölland och Äland: 2013 avser 2012 års uppgifter. 
65+ year-olds as per cent of population aged 20-64

Åldersgruppen 65+ år i procent av åldersgruppen 20-64 å Per cent

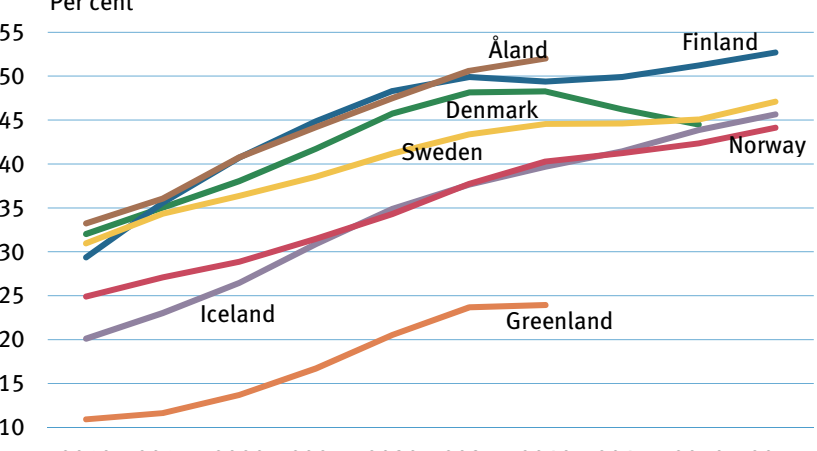

$\begin{array}{llllllllll}2010 & 2015 & 2020 & 2025 & 2030 & 2035 & 2040 & 2045 & 2050 & 2055\end{array}$

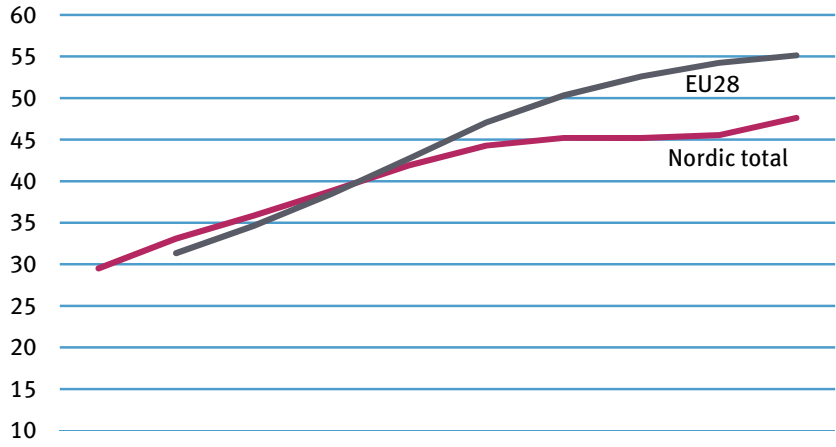

$\begin{array}{llllllllll}2010 & 2015 & 2020 & 2025 & 2030 & 2035 & 2040 & 2045 & 2050 & 2055\end{array}$

\section{므 Popu06}

Source: National statistical institutes and Eurostat.

Note: 2028 : The 28 member states of the European Union as per 1 January 2014.

Not: EU28: De 28 medlemstrtena i Europeiska unionen per 1 januari 2014.

\section{Dependency ratio}

In the next 25 years, the demographic dependency ratio is expected to have the strongest growth in Finland and Alland. Today there are 3.3 people of working age, i.e. the $20-64$-year-olds, for every person over the age of 65 . According to the most recent population forecasts in Finland and Åland, in 2030, it is expected that people over 65 will make up 50 per cent of the adult population (i.e. people aged 20-64). Sweden and Denmark can look forward to a relatively modest increase in the next decades. Iceland and Norway seem to maintain their positions with the lowest proportions of elderly people in the Nordic countries.

In the Nordic countries, the population older than 65 years make up 29.5 per cent of the population between 20 and 64 years old. The percentage is a little higher than for the EU28. After $2030 \mathrm{it}$ seems as the EU28 will have a steeper increase of elderly than the Nordic countries. In 2040, the proportion will reach 50 per cent in the EU28 and 45 in the Nordic countries.

\section{The population is getting older}

According to the population projection for the Nordic countries as a whole, the share of the population above the age of 80 will reach 8.6 per cent in 2040 , as compared to the current 4.8 per cent.

The share of population 80 years or older has increased from 1990 to 2013. The increase in the share of people above the age of 80 over the last 10 years is partly due to the fact that the death rate has fallen for almost all age groups and partly that the number of births has been low during the same period.
Försörjningsbördan

Under de kommande 25 åren förväntas den demografiska försörjningsbördan ha den starkaste tillväxten i Finland och på Åland. I dag finns det 3,3 personer i arbetsför ålder, d.v.s. 20-64-åringar, för varje person över 65 år. Enligt de senaste befolkningsprognoserna i Finland och på Åland förväntas det att personer över 65 kommer att utgöra 50 procent av den vuxna befolkningen (d.v.s. personer i åldern 20-64) år 2030. Danmark och Sverige kan se fram emot en relativt blygsam ökning under de kommande årtiondena. Island och Norge ser ut att behålla sina positioner med de lägsta andelarna äldre i de nordiska länderna.

I de nordiska länderna utgör befolkningen äldre än 65 år 29,5 procent av befolkningen mellan 20 och 64 år. Den procentuella andelen är lite högre än i EU28. Efter 2030 verkar det som EU28 kommer att ha en större ökning av äldre än de nordiska länderna. År 2040 kommer andelen att nå 50 procent i EU28 och $45 \mathrm{i}$ de nordiska länderna.

Befolkningen blir allt äldre

Enligt befolkningsprognoserna för de nordiska länderna som helhet kommer den andel av befolkningen som är över 80 år att uppgå till 8,6 procent under år 2040, jämfört med nuvarande 4,8 procent.

Andelen av befolkningen som är 80 år eller äldre har ökat från 1990 till 2013. Ökningen av andelen invånare över 80 år under den senaste 10-årsperioden beror delvis på att dödstalen har minskat $\mathrm{i}$ nästan alla åldersgrupper och delvis på att antalet födslar har varit lågt under samma period. 
Population changes

The population increase in the Nordic countries during recent years is partly the result of a natural increase (live births minus deaths) and partly a positive net migration (immigration minus emigration). A positive net migration means that more people enter the country than leave.

In 2013, net migration had the greatest impact on the population increase in Sweden. That was also the case with Denmark, Finland and Norway. In the Faroe Islands, Greenland and Iceland, natural population increase had the greatest impact on the population change. But Greenland still had a slight decrease in the population due to a negative net migration in 2013.

Befolkningsförändringar

Befolkningsökningen i de nordiska länderna under senare år är delvis ett resultat av en naturlig ökning (antalet födda minskat med antalet döda) och delvis av en positiv nettomigration (invandring minskat med utvandring). En positiv nettomigration betyder att det är fler människor som kommer in i landet än som lämnar det.

Nettomigrationen har år 2013 haft störst inverkan på befolkningsutvecklingen i Sverige. Detta gäller också Danmark, Finland och Norge. På Färöarna, Grönland och Island var den naturliga befolkningsförändringen av störst betydelse. Men Grönland hade fortfarande en liten minskning i befolkningen på grund av en negativ nettomigration under 2013.

Denmark Faroe Is. Greenland Finland Åland Iceland Norway Sweden

Persons

Population 1 January 2013

Live births

Deaths

Natural population increase

Immigration

Emigration

Net migration

Population increase

Corrections

Population 1 January 2014

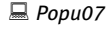

Source: National statistical institutes.

Note: Finland: Includes Åland.

ot: Finland: Inkluderar Âland.

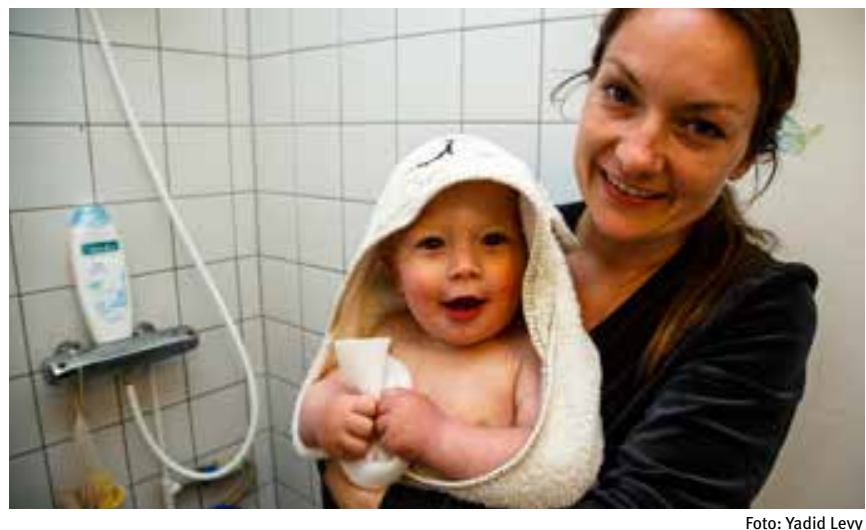

$\begin{array}{rrrr}5594782 & 48092 & 56370 & 5426674 \\ 55873 & 624 & 820 & 58134 \\ 52471 & 364 & 444 & 51472 \\ 3402 & 260 & 376 & 6662 \\ 75163 & 1432 & 2066 & 31941 \\ 48133 & 1556 & 2513 & 13893 \\ 27030 & -124 & -447 & 18048 \\ 30432 & 136 & -88 & 24710 \\ -814 & 0 & -17 & 114 \\ 5627235 & 48228 & 56282 & 5451270\end{array}$

28502
287
269
861
7
147
165
28
Personer

Folkmängd 1 januari 2013

Döda

Naturlig folkökning

Invandring

Utvandring

Nettomigration

Folkökning

Avvikelse
$3814 \quad 57781 \quad 88971$

$44 \quad 0 \quad 650$

$325671 \quad 5109056 \quad 9644864$
Did you know that ... women in the Nordic countries now can expect to live more than 83 years. In the early 60 s, women could "only" expect to be 74 years old on average.

Visste du att ... kvinnor i Norden nu kan förvänta sig att leva mer än 83 år. I början på 60-talet kunde kvinnor "bara" räkna med att bli 74 år gamla i genomsnitt. 


\section{Population projections}

The population projections are based on assumptions relating to fertility, mortality, immigration and emigration in the future, which are naturally subject to uncertainty. The most certain projections concern the development in the number of elderly, as their number is already known.

The fastest increase in the population figure is seen in Iceland, Norway and Åland. According to the latest population projections, the population figure is, during the next 25 years, expected to increase by 25 per cent in Åland. In Norway, an increase of 28 per cent is expected, while the increase in Iceland is expected to be 22 per cent.

The Danish population is expected to increase between 7 and 8 per cent until 2035, while Finland and Sweden expect an increase in the population of about 10 and 16 per cent respectively.

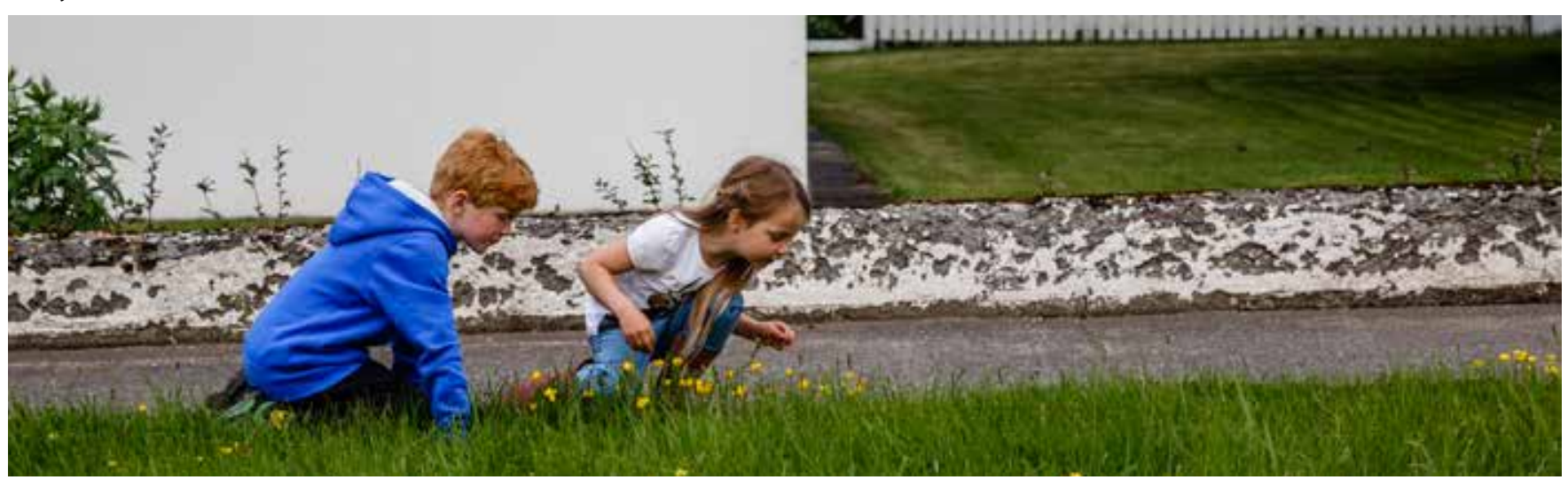

Foto: Yadid Levy
Befolkningsprognoser

Dessa befolkningsprognoser utgår ifrån ett antal antaganden om framtida fertilitet, dödstal samt in- och utvandring, vilka självklart är osäkra. De mest tillförlitliga siffrorna är de som anger utvecklingen av antalet äldre, eftersom man redan känner deras antal.

Befolkningen växer snabbast på Island, i Norge och på Åland. Enligt de senaste befolkningstillväxtprognoserna förväntas befolkningen inom de närmaste 25 åren att växa med 25 procent på Åland. I Norge förväntas ökningen bli 28 procent och på Island 22 procent.

Den danska befolkningen förväntas växa mellan 7 och 8 procent fram till 2035, medan Finland och Sverige kan se fram emot en befolkningsökning på 10 respektive 16 procent.
Population trends according to latest population projections Figure 3.2 Befolkningen enligt de senaste befolkningsprognoserna

145 Index 2010=100

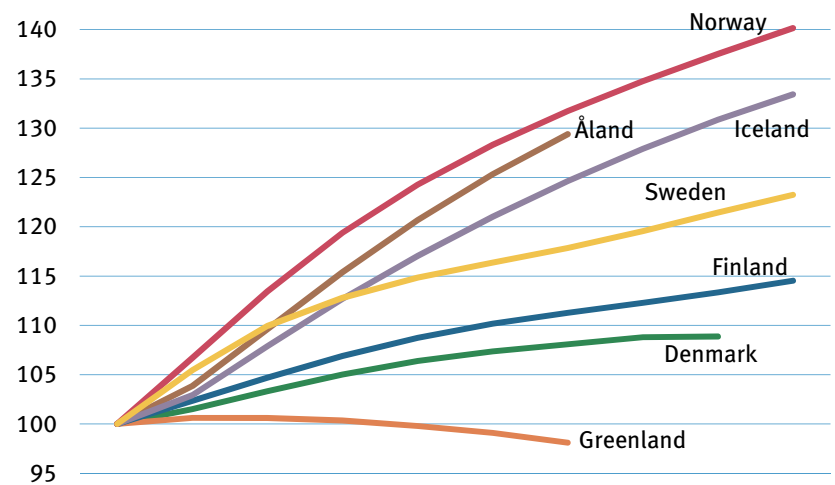

$\begin{array}{llllllllll}2010 & 2015 & 2020 & 2025 & 2030 & 2035 & 2040 & 2045 & 2050 & 2055\end{array}$ 므 Popu06 and PopuO Source: National statistical institutes.
Did you know that ... the Faroe Islands, Greenland and Iceland have the highest fertility rates in the Nordic countries.

Visste du att ... Färöarna, Grönland och Island har de högsta fruktsamhetstalen i de nordiska länderna. 


\section{Fertility}

The number of births depends, among other things, on the number of women in the child-bearing age group - the ages of 15-49 - and the pattern of pregnancies and birth frequency in the various age groups. A measure for calculating this is the total fertility rate, which is the average number of live births per 1000 women of child-bearing age. Thus, the total fertility rate is comparable, despite differences in the demographic structure in different countries. However, the fertility rates tend to fluctuate more in the smaller countries than in larger countries, since only a few births still heavily can influence the fertility rate. The fertility rate can give an impression of whether a population increases or decreases. If the fertility rate is 2.1 the population will remain at the same size.
Women in the Nordic countries give birth to a relatively high number of children, compared to the other European countries. The Faroe Islands, Greenland and Iceland have the highest fertility rates, and the lowest rates are seen in Denmark and Finland.

Fruktsamhet

Antalet födslar beror bland annat på antalet kvinnor i barnafödande ålder - 15-49 år - och på fruktsamheten i olika åldersgrupper. Ett mått på fruktsamheten är det summerade fruktsamhetstalet, beräknat som ett genomsnitt av antalet levande födda per 1000 kvinnor i barnafödande ålder. Detta mått på fruktsamheten är oberoende av demografisk struktur och kan därför användas för jämförelser mellan olika länder. Fruktsamheten

Fertility rate by mother's age, per 1000 women. 2013 Table 3.4 Fruktsamhet efter moderns ålder, per 1000 kvinnor

\begin{tabular}{|c|c|c|c|c|c|c|c|c|c|}
\hline & Denmark & Faroe Is. & Greenland & Finland & Åland & Iceland & Norway & Sweden & \\
\hline Live births & & & & & & & & & Levande födda \\
\hline $\begin{array}{l}\text { Total } \\
\text { fertility rate }\end{array}$ & 1668.7 & 2489.9 & 1985.9 & 1747.1 & 1847.0 & 1932.0 & 1782.0 & 1888.3 & $\begin{array}{r}\text { Summerade } \\
\text { fruktsamhetstal }\end{array}$ \\
\hline-19 years & 2.9 & 18.9 & 40.0 & 7.3 & 1.2 & 7.1 & 5.6 & 4.9 & -19 år \\
\hline $20-24$ years & 29.8 & 97.7 & 106.0 & 50.7 & 56.0 & 62.2 & 48.4 & 45.6 & $20-24$ år \\
\hline $25-29$ years & 99.3 & 146.2 & 117.1 & 105.8 & 116.5 & 117.7 & 113.5 & 111.5 & $25-29$ år \\
\hline $30-34$ years & 126.9 & 149.0 & 81.6 & 114.5 & 116.4 & 117.0 & 120.4 & 132.8 & $30-34 \mathrm{ar}$ \\
\hline $35-39$ years & 60.9 & 71.6 & 45.3 & 59.1 & 69.3 & 65.8 & 56.8 & 68.1 & $35-39 a ̊ a r$ \\
\hline 40-44 years & 13.1 & 14.5 & 6.3 & 12.5 & 10.2 & 14.9 & 10.7 & 13.9 & $40-44$ àr \\
\hline $45+$ years & 0.7 & - & 0.8 & 0.6 & . & 1.8 & 0.5 & 0.8 & $45+$ år \\
\hline
\end{tabular}

Schrce:

Genland and Åland: 2012 dato.

Not: Finland: Inkluderar Åland. Grönland och Äland: 2012 ărs uppgifter.

tenderar dock att fluktuera mer i de mindre länderna än i de större länderna, eftersom endast ett fåtal födslar kan påverka fruktsamhetstalen kraftigt. Fruktsamheten kan ge en bild av om en befolkning ökar eller minskar. Om fruktsamheten är 2,1 kommer befolkningens storlek att förbli densamma.

Kvinnor i de nordiska länderna har ett relativt högt födelseta jämfört med övriga Europa. Högst fruktsamhet har Färöarna, Grönland och Island, lägst har Danmark och Finland.

Fertility rate per woman Figure 3.3

Fruktsamhetstal per kvinn

$$
\text { Number of children }
$$

2.8

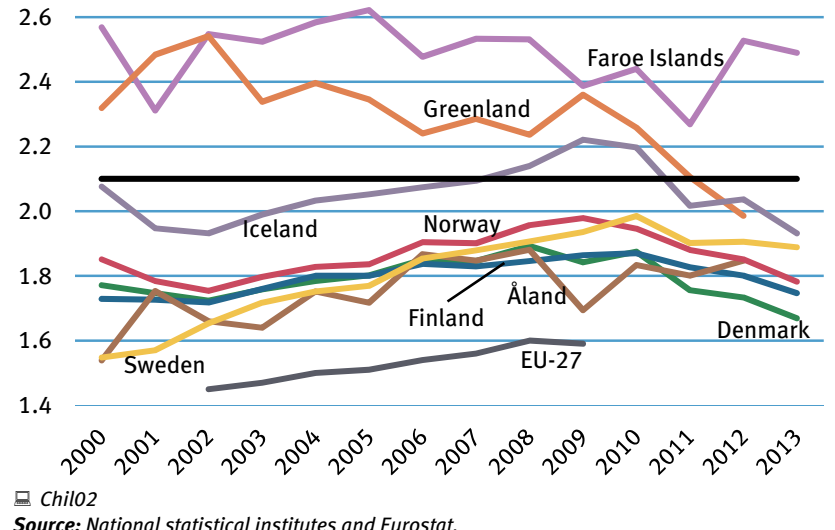

Source: National statistical institutes and Eurostat.

Note: Finland: Includes Åland. EU27: The 27 member states of the European Union as per 1 January 2013.

Not: Finland: Inkluderar Åland. EU27: De 27 medlemsstaterna i Europeiska unionen per 1 


\section{Abortions}

Since the mid 1970s, induced abortions have been available in most of the Nordic countries. In Denmark, Greenland, Norway and Sweden, it is entirely up to the pregnant woman in the early stages of pregnancy to determine whether to have an abortion. In the Faroe Islands, Finland, Åland and Iceland, a leave based on social and/or medical criteria is required.

Greenland has the highest rate of abortions with 893 abortions per 1000 live births. Sweden has the second highest with a rate of 335. The Faroe Islands has the lowest with 56 abortions per 1000 live births. Since 2000, the abortion rate has risen in Denmark, Åland and Norway and decreased in the rest of the Nordic countries.

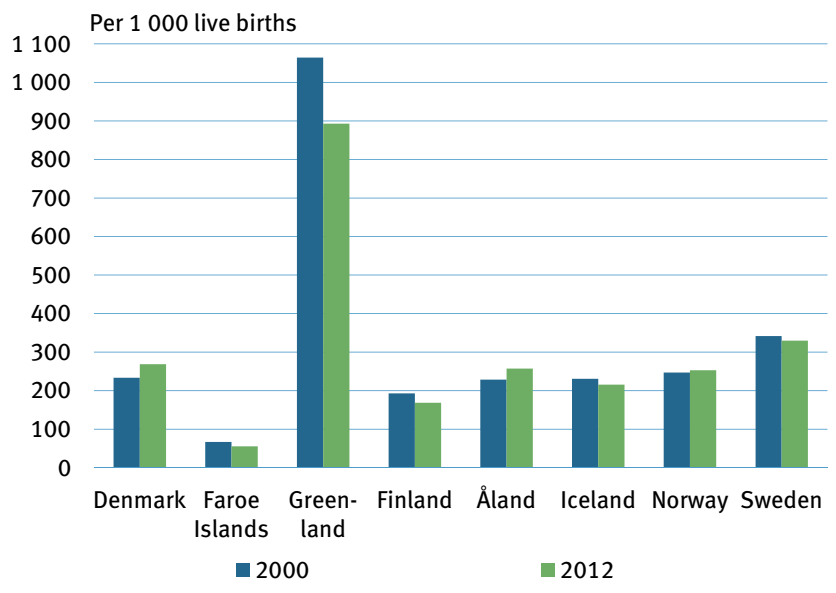

Sedan mitten på 1970-talet har det varit möjligt att få göra abort i flertalet nordiska länder. I Danmark, på Grönland, i Norge och Sverige är det den gravida kvinnan som tidigt $i$ graviditeten kan bestämma om hon vill ha abort. På Färöarna, i Finland, på Åland och Island krävs tillstånd som grundas på sociala och/eller medicinska kriterier.

Grönland har den högsta abortfrekvensen med 893 aborter per 1000 levande födda. Sverige har den näst högsta frekvensen med 335 aborter per 1000 levande födda. Färöarna har den lägsta med 56 aborter. Antalet aborter har sedan 2000 ökat i Danmark, på Åland och i Norge och gått ner i de övriga nordiska länderna.

므 Heal15

Source: NOMESCO.

d and Åland: 2009 data.

Not: Färöarna: 2008 års uppgifter. Grönland och Åland: 2009 års uppgifter.

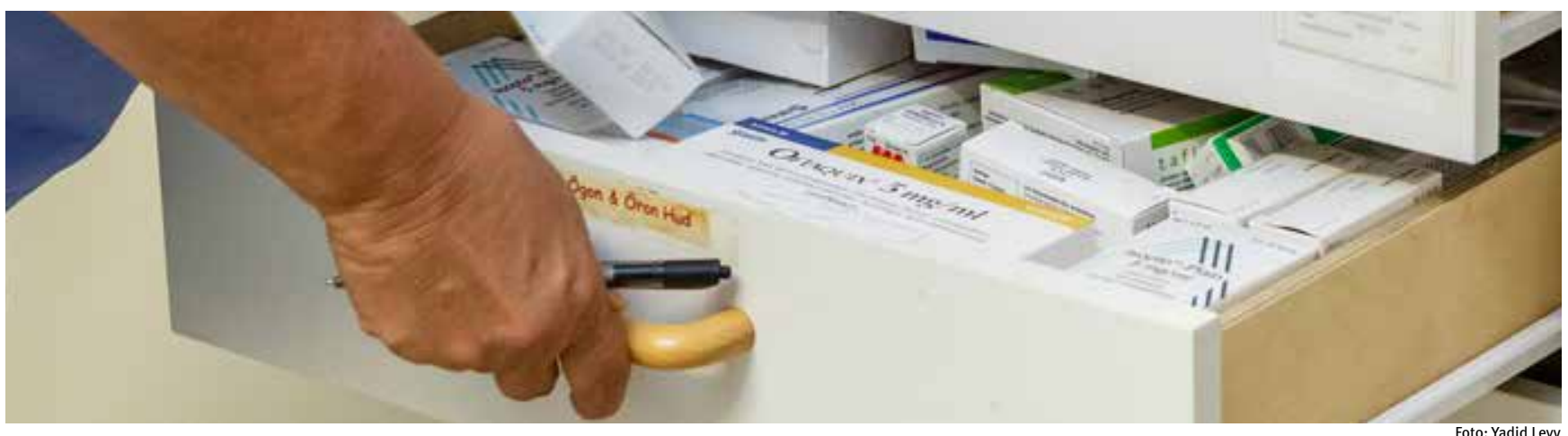




\section{Families}

A family consists either of one person or several persons related to each other. Most families correspond to a household. A household includes all people, related or not, living at the same address, sharing a house or a flat. Households might, therefore, include more than one family.

About 22 per cent of all families in the Nordic countries have children. Of these families, most - around 77 per cent - consist of married or cohabiting couples.

Familjer

En familj består antingen av en person eller av flera persone som är släkt med varandra. De flesta familjer motsvarar ett hushåll. Ett hushåll inbegriper alla personer som bor på samma adress och delar bostad - vare sig de är släkt eller inte.

Ett hushåll kan därför omfatta mer än en familj.

Runt 22 procent av alla familjer i de nordiska länderna har barn. Av dessa familjer består flertalet - omkring 77 procen - av gifta eller samboende par.

\begin{tabular}{|c|c|c|c|c|c|c|c|}
\hline & Denmark & Finland & Åland & Iceland & Norway & Sweden & \\
\hline 1000 families with children & 772 & 578 & 3 & 49 & 636 & 1112 & 1000 familjer med barn \\
\hline Percent & & & & & & & Procent \\
\hline Total & 100 & 100 & 100 & 100 & 100 & 100 & Totalt \\
\hline Married couples & 60 & 61 & 54 & 57 & 54 & 78 & Gifta par \\
\hline Cohabiting couples & 17 & 19 & 27 & 23 & 25 & .. & Sammanboende par \\
\hline Single people & 23 & 20 & 19 & 20 & 22 & 22 & Ensamstående \\
\hline 1000 families without children & 2103 & 2413 & 9 & 74 & 1722 & 4558 & 1000 familjer utan barn \\
\hline Percent & & & & & & & Procent \\
\hline Total & 100 & 100 & 100 & 100 & 100 & 100 & Totalt \\
\hline Married couples & 27 & 26 & 31 & 44 & 30 & 27 & Gifta par \\
\hline Cohabiting couples & 9 & 9 & 10 & 5 & 8 & .. & Sammanboende par \\
\hline Single people & 65 & 66 & 60 & 51 & 63 & 73 & Ensamstående \\
\hline
\end{tabular}

(a)

Source: NOSOSCO.

Note: Children aged 0-17. Åland: 2002 data. Norway: Cohabiting couples without natural and adopted children are included in Single people. Sweden: Married couples include cohabiting couples. Not: Barn i äldern 0-17 ar. Aland: 2002 àrs uppgifter. Norge: Sammanboende par utan gemensamma barn ingår i Ensanstående. Sverige: Gifta par inbegriper sammanboende par.

Did you know that ... the most popular names to new born babies are:

William and Sofia in Denmark

Rókur and Sára in the Faroe Islands Inutsiaq/Qillaq and Ivaana/Nivi/Niviaq

in Greenland

Onni and Emma in Finland

Emil and Elsa in Åland

Jón and Guðrún in Iceland

Fillip and Emma in Norway and

Lucas and Alice in Sweden.
Visste du att ... de mest populära

namnen för nyfödda är:

William och Sofia i Danmark

Rókur och Sára på Färöarna

Inutsiaq/Qillaq och Ivaana/Nivi/Niviaq

på Grönland

Onni och Emma i Finland

Emil och Elsa på Åland

Jón och Gudrún på Island

Fillip och Emma i Norge och

Lucas och Alice i Sverige. 


\section{Marriages and divorces}

The number of marriages and divorces only comprises so-called legal partnerships. Couples living together without being legally married make up a large share of the partnerships in the Nordic countries. Consequently, the number of marriages and divorces does not give the complete picture of the number of people en-

The number of marriages has increased in almost all the Nordic countries since 1995, except in Denmark where there has been tering partnerships or the dissolution rates. decline. Åland and the Faroe Islands have had the largest increase in the number of divorces since 1995. Finland and Norway have had a decline in the number of divorces since 1995.

Relating the number of marriages and divorces to the mean population, Denmark had the highest divorce rate in 2013.

However, all the Nordic countries have almost the same rate for marriages.
Marriages and divorces. 2013

Giftermål och äktenskapsskillnader

\begin{tabular}{|c|c|c|c|c|c|c|c|c|c|}
\hline & Denmark & $\begin{array}{r}\text { Faroe } \\
\text { Islands }\end{array}$ & Finland & Åland & Iceland & Norway & Sweden & $\begin{array}{r}\text { Nordic } \\
\text { total }\end{array}$ & \\
\hline Number & & & & & & & & & Antal \\
\hline Marriages & 27140 & 259 & 25119 & 118 & 1458 & 23410 & 45703 & 123208 & Giftermål \\
\hline Divorces & 18872 & 77 & 13766 & 54 & 516 & 9736 & 25110 & 68141 & Skilsmässor \\
\hline Per 1000, mean population & & & & & & & & & Per 1000, medelfolkmängd \\
\hline Marriages & 4.8 & 5.4 & 4.6 & 4.1 & 4.6 & 4.6 & 4.8 & 4.7 & Giftermål \\
\hline Divorces & 3.4 & 1.6 & 2.5 & 1.9 & 1.6 & 1.9 & 2.6 & 2.6 & Skilsmässor \\
\hline
\end{tabular}

马 Popu04

Not: Finland: Inkluderar Ålond Island: 2011 ars uppgifter.

Table 3.6
Source: National statistical institutes.

4.0 Divorces per 1000 mean population

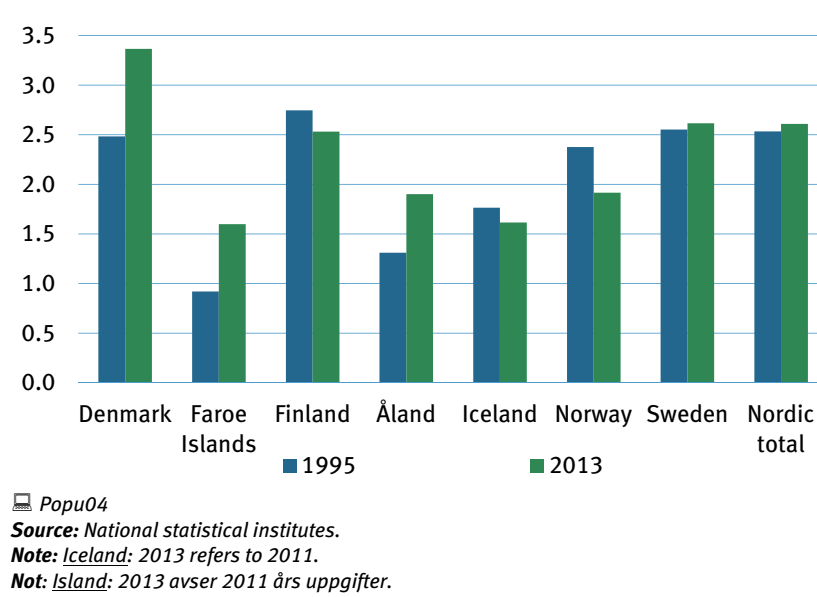

Not: Island: 2013 avser 2011 års uppgifter.

44 Population - Befolkning
Did you know that ... there are many more singles in the Nordic countries today than in the beginning of the $60 \mathrm{~s}$.

The number of people who are single has risen from around 39 per cent of the population to now around 57 per cent.

Visste du att ... det finns många fler singlar i Norden $i$ dag än i början av 60-talet. Antalet personer som är ningen till cirka 57 procent. ensamstående har ökat från cirka 39 procent av befolk- 
Giftermål och skilsmässor

Antalet giftermål och skilsmässor omfattar här endast relationer i juridisk mening. Många par i de nordiska länderna bor tillsammans utan att vara lagligen gifta. Följaktligen ger antalet giftermål och skilsmässor inte en fullständig bild av det antal invånare som flyttar ihop eller flyttar isär.

Antalet ingångna äktenskap i nästan alla de nordiska länderna har ökat sedan 1995, utom i Danmark som har haft en minskning.
Åland och Färöarna har haft den största ökningen i antalet skilsmässor sedan 1995. Finland och Norge har haft en minskning i antalet skilsmässor sedan 1995.

När man relaterar antalet äktenskap och skilsmässor till medelfolkmängden hade Danmark den högsta andelen skilsmässor under 2013. Dock hade alla de nordiska länderna nästan samma höga andel äktenskap.
Marital status. People aged 15 and more. 1 January 2014 Civilstånd. Personer 15 år och äldre

Denmark Faroe Is. Greenland Finland

\section{0 persons}

\section{Total}

Unmarried

Married and separated

Divorced

Registered partners

Dissolved partnerships, persons

Widow/widowers

$\begin{array}{rrrr}4658.6 & 38.0 & 44.2 & 4556.2 \\ 1718.4 & 15.0 & 23.7 & 1705.8 \\ 2146.6 & 18.6 & 15.0 & 2013.2 \\ 483.7 & 2.0 & 3.6 & 542.6 \\ 8.0 & . . & . . & 5.0 \\ 2.6 & . . & . . & 0.9 \\ 299.2 & 2.4 & 1.9 & 288.7\end{array}$

묘 Роpu03

Source: National statistical institutes.

Fing Includes Åland.

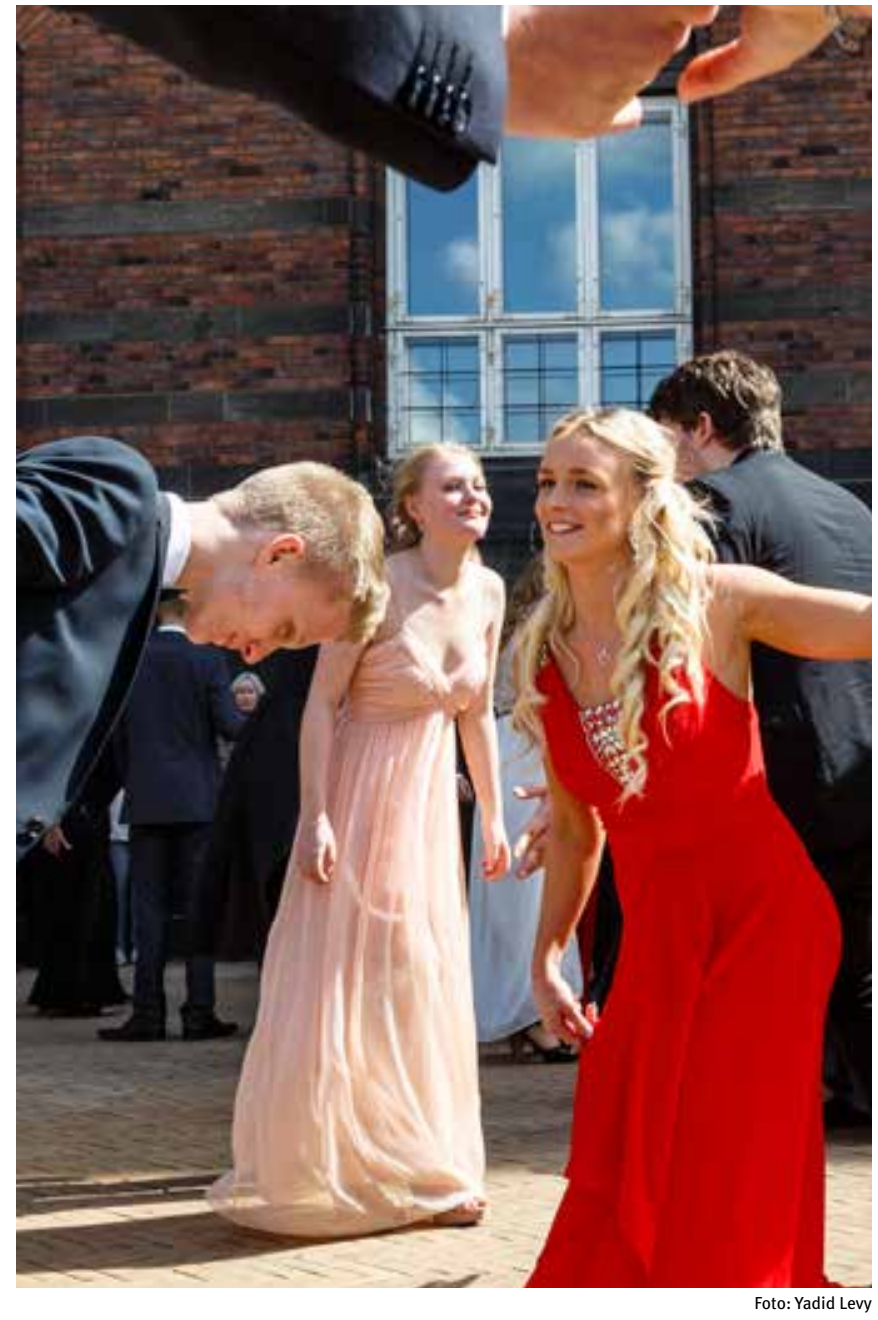

Foto: Yadid Lew 


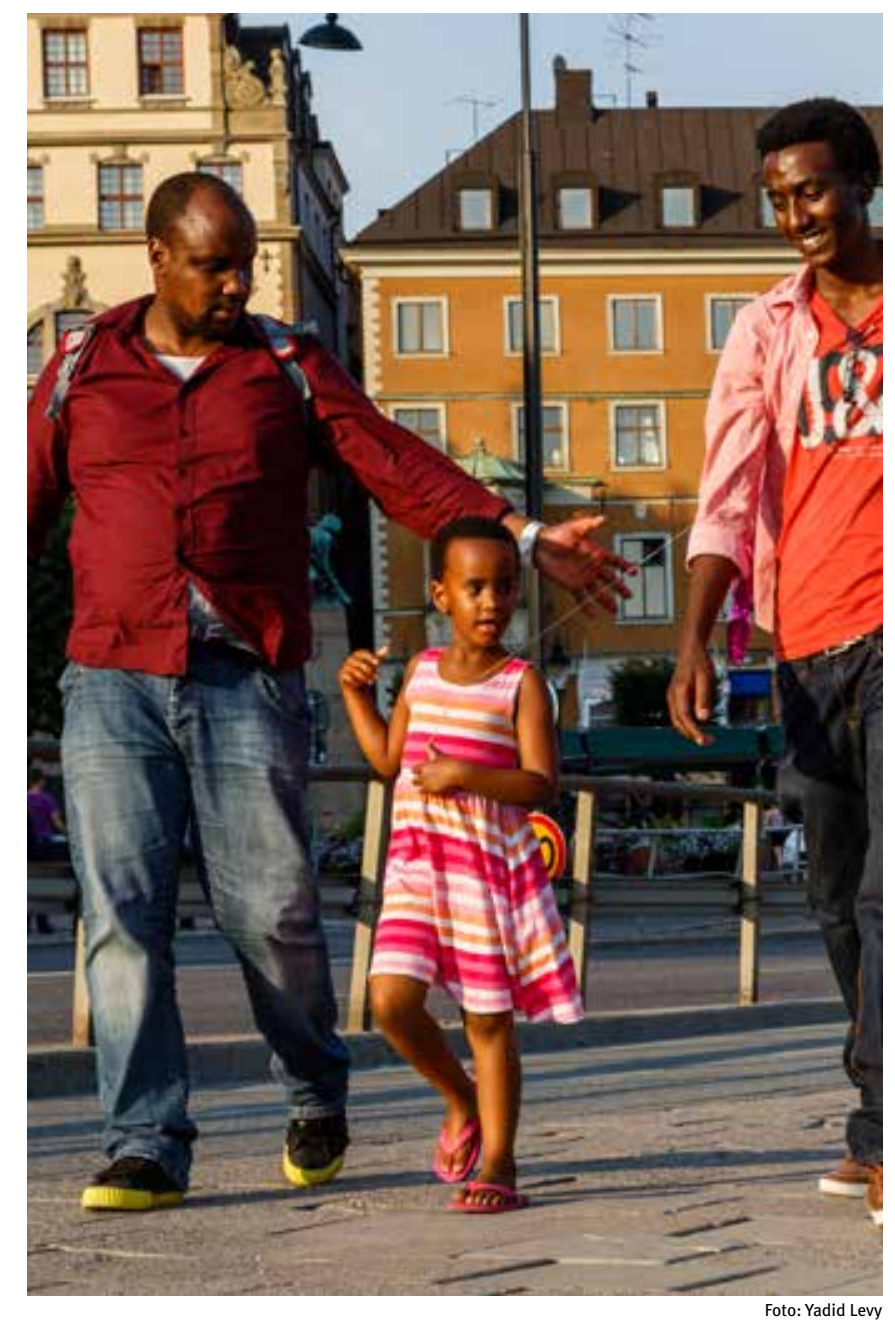

\section{Migration}

Immigration includes both returning citizens and citizens of a foreign nation who have been granted permission to stay and are registered with the public authorities. A large proportion of the migration occurs between and among the Nordic countries themselves, largely as the result of the free labour market and liberal rules for the exchange of students in the Nordic countries. Foreign immigrants are designated by country of origin rather than by citizenship. Those from the former USSR are shown as immigrants from non-EEA Europe. EEA comprises the $27 \mathrm{EU}$ countries and Norway, Iceland and Liechtenstein.

The trend has led to an increasing number of foreign citizens in the Nordic countries. In all the countries, the major part of the foreign citizens is non-Nordic. That is not the case for Greenland and the Faroe Islands, which have a high proportion of other Nordic citizens. The decline in the number of foreign citizens during certain periods may be due to the fact that more foreign citizens obtain citizenship in one of the Nordic countries. Non-nationals range from 56 per cent of the total immigration in Iceland, to 88 per cent in Norway. In 2013 we find the largest proportions of non-nationals in Denmark and Norway where they account for 11.1 and 9.5 per cent of the population. The proportion of non-nationals in the Finnish population is small com pared to the other Nordic countries - 3.8 per cent in 2013 - but the proportion has risen significantly in the 1990s.
Migration

Invandringen inkluderar både återvändande medborgare och medborgare i ett främmande land som har fått uppehållstillstånd och är registrerade hos myndigheterna. En stor andel av migrationen sker mellan de nordiska länderna själva, till stor del på grund av den fria arbetsmarknaden och de liberala reglerna för studentutbyte. Utländska invandrare indelas med hänsyn till ursprungsland i stället för medborgarskap. De som kommer från det forna Sovjet anges som immigranter från Europa utom EES. EES består av de 27 EU-länderna samt Norge, Island och Liechtenstein.

Utvecklingen har lett till ett ökat antal utländska medborgare i de nordiska länderna. I alla länder är huvuddelen av dessa utländska medborgare utomnordiska utom på Grönland och Färöarna, vilka har en stor andel andra nordiska medborgare. Minskningen av antalet utländska medborgare under vissa perioder kan bero på att fler utländska medborgare får nordiskt medborgarskap. Icke-medborgare står för 56 procent av den totala invandringen till Island, men för 88 procent i fråga om Norge. År 2013 finner vi den största andelen utländska medborgare i Danmark och Norge, där de står för 11,1 respektive 9,5 procent av befolkningen. Andelen icke-medborgare i den finländska befolkningen är liten jämfört med de andra nordiska länderna - 3,8 procent under 2013 - men har ökat kraftigt under 1990-talet. 
Invandring

\section{Persons from \\ Total}

Denmark

Faroe
Islands

Greenland

Finland
incl. Åland

Iceland

Norway

Sweden

Denmark

Faroe Islands

Greenland

Finland

Norway

Sweden

Sweden
Baltic countries

Poland

Other Europ

America

Asia

Oceania

Unknown and stateless

of which foreign citizens

Total

Denmark

Faroe Islands

Greenland

Finland

Iceland

Norway

Sweden

Baltic countries

Poland

Other EEA

Other Europ

America

Africa
Asia

Asia
Oceania

Unknown and stateless

75163
1276
2365
490
832
3189
5087
2981
4461
26209
3965
7765
2720
13392
30
401

2066

1432
1063
.
37
1
25
34
22
7
5
102
10
27
24
68
5
2

31941

7071

75789

Sweden

Personer från

\section{Invandring, totalt}

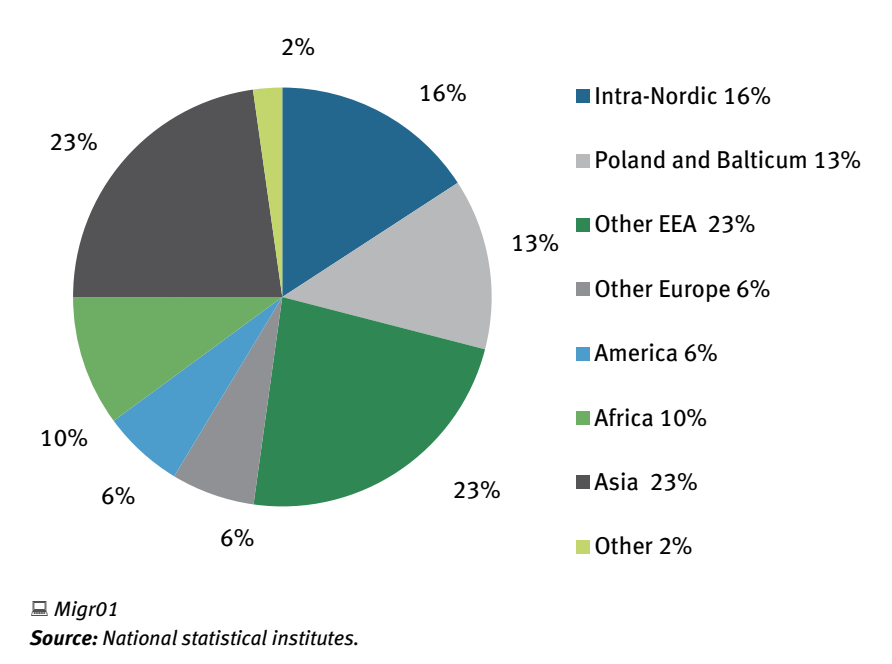

\begin{tabular}{|c|c|c|c|c|c|c|c|}
\hline 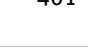 & & & & & & & Varav utländska medborgare \\
\hline 53999 & 132 & 130 & 23873 & 3932 & 66934 & 95361 & Totalt \\
\hline & 12 & 33 & 89 & 106 & 2598 & 2572 & Danmark \\
\hline 22 & & 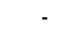 & - & 34 & 73 & & Färöarna \\
\hline 32 & 6 & . & - & 6 & 15 & & Grönland \\
\hline 447 & 1 & 1 & 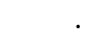 & 31 & 516 & 2222 & Finland \\
\hline 727 & 11 & 18 & 10 & & 1048 & 517 & Island \\
\hline 2160 & 4 & 5 & 107 & 62 & & 2147 & Norge \\
\hline 2229 & 4 & 14 & 714 & 81 & 5499 & & Sverige \\
\hline 2924 & 3 & 2 & 6385 & 271 & 7431 & 2207 & Baltikum \\
\hline 4390 & 4 & 1 & 491 & 1311 & 10269 & 4424 & Polen \\
\hline 19877 & 13 & 11 & 3158 & 1080 & 14079 & 15815 & Övriga EES \\
\hline 2894 & 10 & 1 & 4240 & 145 & 3187 & 6965 & Övriga Europa \\
\hline 5288 & 11 & 6 & 736 & 334 & 2520 & 3616 & Amerika \\
\hline 1848 & 10 & 1 & 1771 & 108 & 7466 & 17538 & Afrika \\
\hline 10926 & 42 & 33 & 5942 & 317 & 10913 & 34257 & Asien \\
\hline 30 & - & 1 & 100 & 22 & 349 & 420 & Oceanien \\
\hline 205 & 1 & 3 & 130 & 24 & 971 & 2661 & Okänt land och statslösa \\
\hline
\end{tabular}

$\begin{array}{rr} & \text { Personer från } \\ 15845 & \text { Totalt } \\ 3676 & \text { Danmark } \\ - & \text { Färöarna } \\ - & \text { Gröland } \\ 2737 & \text { Finland } \\ 628 & \text { Island } \\ 6220 & \text { Norge } \\ 23 & \text { Sverige } \\ 2304 & \text { Baltikum } \\ 4562 & \text { Polen } \\ 21869 & \text { Övriga EES } \\ 7715 & \text { Övriga Europa } \\ 6012 & \text { Amerika } \\ 18393 & \text { Afrika } \\ 37584 & \text { Asien } \\ 899 & \text { Oceanien } \\ 3246 & \text { Okänt land och statslösa } \\ & \text { Varavutländska medborgare } \\ 95361 & \text { Totalt } \\ 2572 & \text { Danmark } \\ - & \text { Färöarna } \\ - & \text { Gröland } \\ 2222 & \text { Finland } \\ 517 & \text { Island } \\ 2147 & \text { Norge } \\ 207 & \text { Sverige } \\ 2207 & \text { Baltikum } \\ 4424 & \text { Polen } \\ 15815 & \text { Övriga EES } \\ 6965 & \text { Övriga Europa } \\ 3616 & \text { Amerika } \\ 17538 & \text { Afrika } \\ 34257 & \text { Asien } \\ 420 & \text { Oceanien } \\ 2661 & \text { Okänt land och statslösa } \\ & \end{array}$

Source: National statistical institutes.

Migro1
Source: National statistical institutes. 


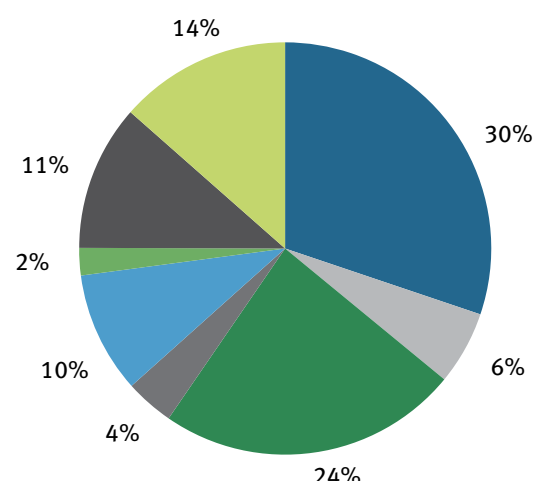

- Intra-Nordic 30\%

Poland and Balticum 6\%

$\%$ Other EEA $24 \%$

- Other Europe $4 \%$

- America $10 \%$

- Africa $2 \%$

- Asia $11 \%$

- Other $14 \%$

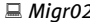

Source: National statistical institutes.

\begin{tabular}{|c|c|}
\hline & Denmark \\
\hline \multirow{2}{*}{\multicolumn{2}{|c|}{$\begin{array}{l}\text { Persons to: } \\
\text { Total }\end{array}$}} \\
\hline & \\
\hline Faroe Islands & 1031 \\
\hline Greenland & 1864 \\
\hline Finland & 384 \\
\hline Iceland & 1067 \\
\hline Norway & 3997 \\
\hline Sweden & 3491 \\
\hline Baltic countries & 1281 \\
\hline Poland & 1620 \\
\hline Other EEA & 14861 \\
\hline Other Europe & 2348 \\
\hline America & 6055 \\
\hline Africa & 954 \\
\hline Asia & 6028 \\
\hline Oceania & 1078 \\
\hline Unknown and stateless & 2074 \\
\hline \multicolumn{2}{|l|}{ Of which foreign citizens } \\
\hline Total & 27506 \\
\hline Denmark & \\
\hline Faroe Islands & 8 \\
\hline Greenland & 33 \\
\hline Finland & 343 \\
\hline Iceland & 939 \\
\hline Norway & 2149 \\
\hline Sweden & 1315 \\
\hline Baltic countries & 1220 \\
\hline Poland & 1547 \\
\hline Other EEA & 8819 \\
\hline Other Europe & 1575 \\
\hline America & 3545 \\
\hline Africa & 325 \\
\hline Asia & 3448 \\
\hline Oceania & 395 \\
\hline Unknown and stateless & 1845 \\
\hline
\end{tabular}

Greenland $\begin{array}{r}\text { Finland } \\ \text { incl. Åland }\end{array}$

Iceland

cl. Alland

13893

2513
2376

2513
2376
17

47

472

5473
809
29
7
26
5
1055
616
190
539
1072
179
514
89
230
64
54

35716
3117
36
1
405
739
6192
761
1539
4963
671
1952
834
2545
352
11609

5716
3117
36
1
405
739
6
6192

20

Personer till:

Totalt

Danmark

Färöarna

Grönland

44

550
2759
1203

1203
107

107
4277

819
1438

247
1327

1327
346
304

4235

2298

93
16
2
16
5015
-

2568
594

594
6934

$661 \quad 661$

$\begin{array}{rr}761 & 661 \\ 1539 & 1213\end{array}$

$4963 \quad 12075$

471
1952
834

530
834
2545

$2545 \quad 7897$

7151
4301

4301

25036

25036
1250
30

1250
30
1

1
327
679

24603
3361
.

1739

458
1842

$4185^{\circ}$
739

739
1511

1511
2966

571

571
1011
5279
5

$391 \quad 920$

$\begin{array}{lr}974 & 1474 \\ 326 & 566\end{array}$

$\begin{array}{rr}326 & 566 \\ 1414 & 4160\end{array}$

$\begin{array}{rr}168 & 296\end{array}$

10075
Island

Norge
Sverige

Sverige
Baltikum

Poltikum

Övriga EES

Duriga Europa Amerika Amerika
Afrika Afrika
Asien

Oceanien
Okänt land och statslösa Varav utländska medborgare Totalt Danmark Färöarna Grönland Finland Island Norge
Sverige Sverige
Baltikum Baltikum Polen
Övriga EES Övriga EES Övriga Europa Amerika
Afrika Asien

$\square$ Migro2

Source: National statistical institutes. 


\section{Asylum requests}

One way to measure the number of foreigners who want to settle in the Nordic countries is to measure the number of asylum requests. Asylum seekers have entered the country but have not yet been granted leave to stay. For this reason, they do not appear in ordinary population statistics, which only cover persons entered in the population registers.

The patterns of asylum requests have been constantly changin through the years due to both changes in the political situation in the sending countries and changes in policy measures in the receiving countries. Over the last 5-6 years the total number of asylum requests per year in the Nordic countries have varied between 45000 and 75000 .

\section{Granted asylum}

The number of persons who have been granted asylum in the Nordic countries has fluctuated between 13000 and 36000 per year in the recent 5-6 years. As with asylum requests, the fluctuation is influenced by political factors in both the sending and receiving countries.

\section{Asylansökningar}

Ett sätt att räkna antalet utländska medborgare som vill bosätta sig i de nordiska länderna är att utgå ifrån antalet asylansökning ar. De asylsökande har kommit in i landet men har ännu inte bliv beviljade uppehållstillstånd. Av den anledningen finns de inte med i den vanliga befolkningsstatistiken, vilken endast omfattar personer som är registrerade i befolkningsregistret.
Mönstret för asylansökningar har ständigt förändrats genom åren både på grund av förändringar i den politiska situationen i ursprungsländerna och förändringar i politiska åtgärder i de mottagande länderna. Under de senaste 5-6 åren har det samlade antalet asylansökningar per år varierat mellan 45000 och 75000 i de nordiska länderna.

Beviljade asyl

Antalet personer som har beviljats asyl i de nordiska länderna har växlat mellan 13000 och 36000 per år under de senaste 5-6 åren. Som med asylansökningar påverkas antalet beviljade asyl av politiska faktorer i både de sändande och i de mottagande länderna.

\section{Denmark}

Persons who requested asylum

1990

2000

2005

2013

Persons granted asylum

1990

2005

2013

Migro 4
Source: National statistical institutes, Icelandic Directorate of Immigration and Finnish Immigration Service.
Note: Asylum seekers may live in a given country for several years before their case is determined, they are

Not: De asylsökande kan bo i ett visst land under flera år innan deras ärende avgörs. De räknas dock inte som en del av befolkningen före asyl beviljas. Finland Iceland

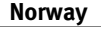

\section{Sweden}

3574

$5107-3018$

3238

5402

17530

54264

$\begin{array}{rr}44 & 11983\end{array}$

\section{6 \\ 1147}

1961
3767

157
458
597
1784

173

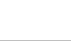

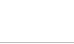

Personer beviljade asyl

$\begin{array}{rrrr}. . & . . & . . & 1990 \\ . . & . . & 7221 & 2000 \\ \ddot{~} & . \ddot{10} & 5358 & 2005 \\ \mathbf{1 6} & 5331 & 8640 & 2010 \\ & \mathbf{5 8 1 8} & \mathbf{2 4 4 9 8} & \mathbf{2 0 1 3}\end{array}$

Did you know that ... the immigration to the Nordic coun tries in the beginning of the 60s mainly came from the other Nordic countries. Today most immigrants come from the rest of Europe.

Visste du att ... invandringen till Norden i början av 60-talet i huvudsak kom från de övriga nordiska länderna. I dag kommer de flesta invandrare från övriga Europa. 


\section{Unaccompanied children}

An unaccompanied child is defined as a person under the age of 18 years, who enters the country without parents or other people responsible for the child. Children who are abandoned when in the country are also treated as unaccompanied.

Around 5500 children arrived in the Nordic countries in 2013 a rise of 7 per cent from 2012, but still at a lower level compared to 2009 when almost 6000 unaccompanied children found their way to the Nordic countries. Sweden and Norway received the most children -3852 and 1070 children respectively.

The majority of the children who come to the Nordic countries are in the age-group 15-17 years. This group made up around 74 per cent of all unaccompanied children in 2013.

Ensamkommande barn

Ett ensamkommande barn definieras som en person under 18 år, som reser in i landet utan föräldrar eller andra personer som ansvarar för barnet. Barn som överges $i$ landet behandlas också som ensamkommande.

Omkring 5500 barn kom till de nordiska länderna ensamma under 2013 - en ökning med 7 procent från 2012, men fortfarande på en lägre nivå jämfört med 2009 då nästan 6000 ensamkommande barn sökte sig till de nordiska länderna. Sverige och Norge tog emot flest barn -3852 respektive 1070 barn.

Majoriteten av de barn som kommer till de nordiska länderna är 15-17 år gamla. Denna åldersgrupp utgjorde ca 74 procent av alla ensamkommande barn under 2013.

$$
\text { Persons }
$$

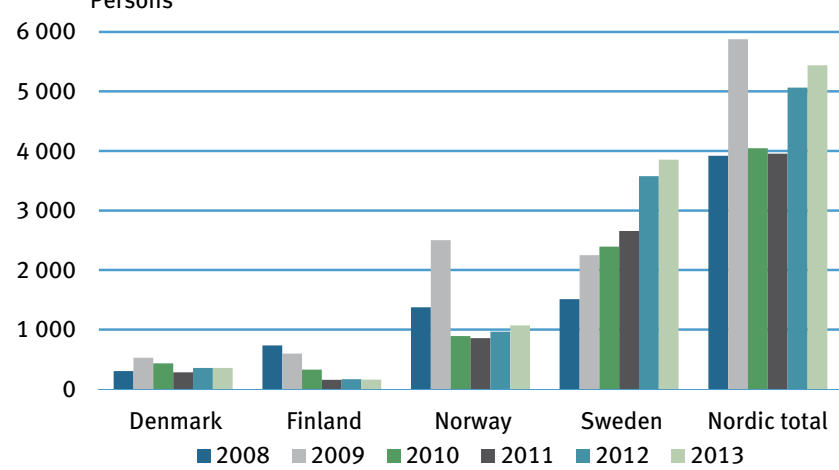

Migro5
Source: The Danish Immigration Service, Finnish Immigration Service, Icelandic Directorate $=2008-2009-2010-2011-2012=2013$ Source: The Danish Immigration Service, Finnish Immigration Service, Icelandic Directorate
of Immigration, the Norwegian Directorate of Immigration and the Swedish Migration Board.

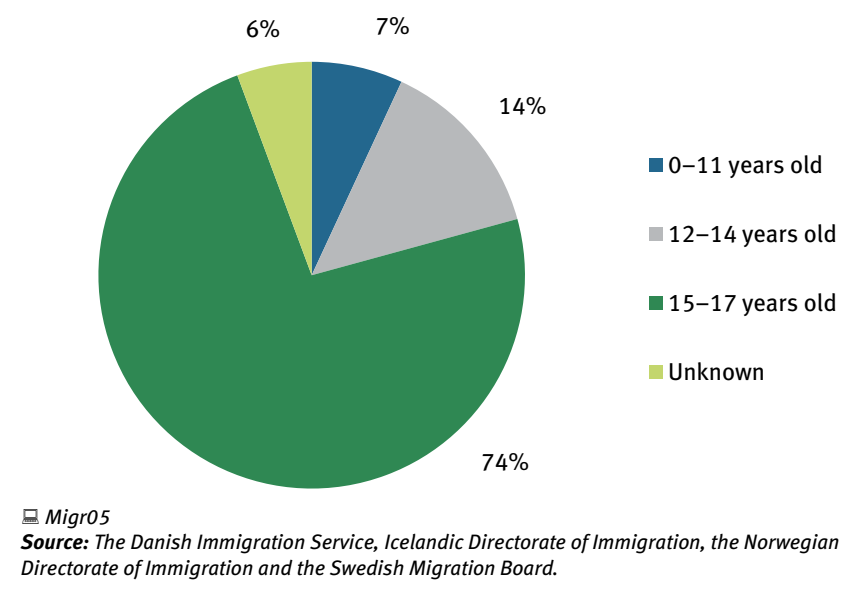




\section{Health \\ Hålsa}

Health service in the Nordic countries is public and, to a large extent, financed through taxes or through compulsory health insurance schemes. In all Nordic countries, except Greenland, citizens contribute directly, either through insurance schemes or by paying user charges for treatment or for pharmaceutical products. In Iceland, contributions are primarily made by the central government, while financing in the other countries consists mainly of county and municipal taxes with block grants from the government.

All the countries have well-established systems of primary health care. In addition to general health care services, preventive services are provided for mothers and infants as well as school health care and dental care for children and young people. Preventive occupational health services and general measures to protect the occupational environment exist in all countries. All countries have generally well-developed hospital services with advanced specialist treatment. Treatment by specialists is also offered outside of hospitals.

While ill, employees either receive their salary or are compensated by special cash allowances. The self-employed usually insure themselves.
Sjukvården i de nordiska länderna är offentlig och i stor utsträckning finansierad genom skatter eller obligatoriska sjukförsäkringssystem. I alla de nordiska länderna, utom på Grönland, bidrar medborgarna direkt - antingen genom försäkringssystem eller genom att betala patientavgifter vid behandling eller för läkemedel. När det gäller Island lämnas bidragen huvudsakligen av staten, medan finansieringen i de andra länderna huvudsak ligen sker genom skatt till landsting och kommuner samt anslag från staten.

Alla länderna har väletablerade system för primär hälsovård. Utöver allmän sjukvård tillhandahålls förebyggande vård för mödrar och nyfödda barn samt skolhälsovård och tandvård för barn och ungdomar. Förebyggande arbetshälsovård och allmänna åtgärder för att skydda arbetsmiljön finns i alla länder. Alla länderna har i allmänhet välutvecklade sjukhus med avancerad specialistbehandling. Behandling av specialister erbjuds också utanför sjukhusen.

Vid sjukdom får de anställda antingen sin lön eller särskild sjukpenning. Egna företagare är normalt självförsäkrade.

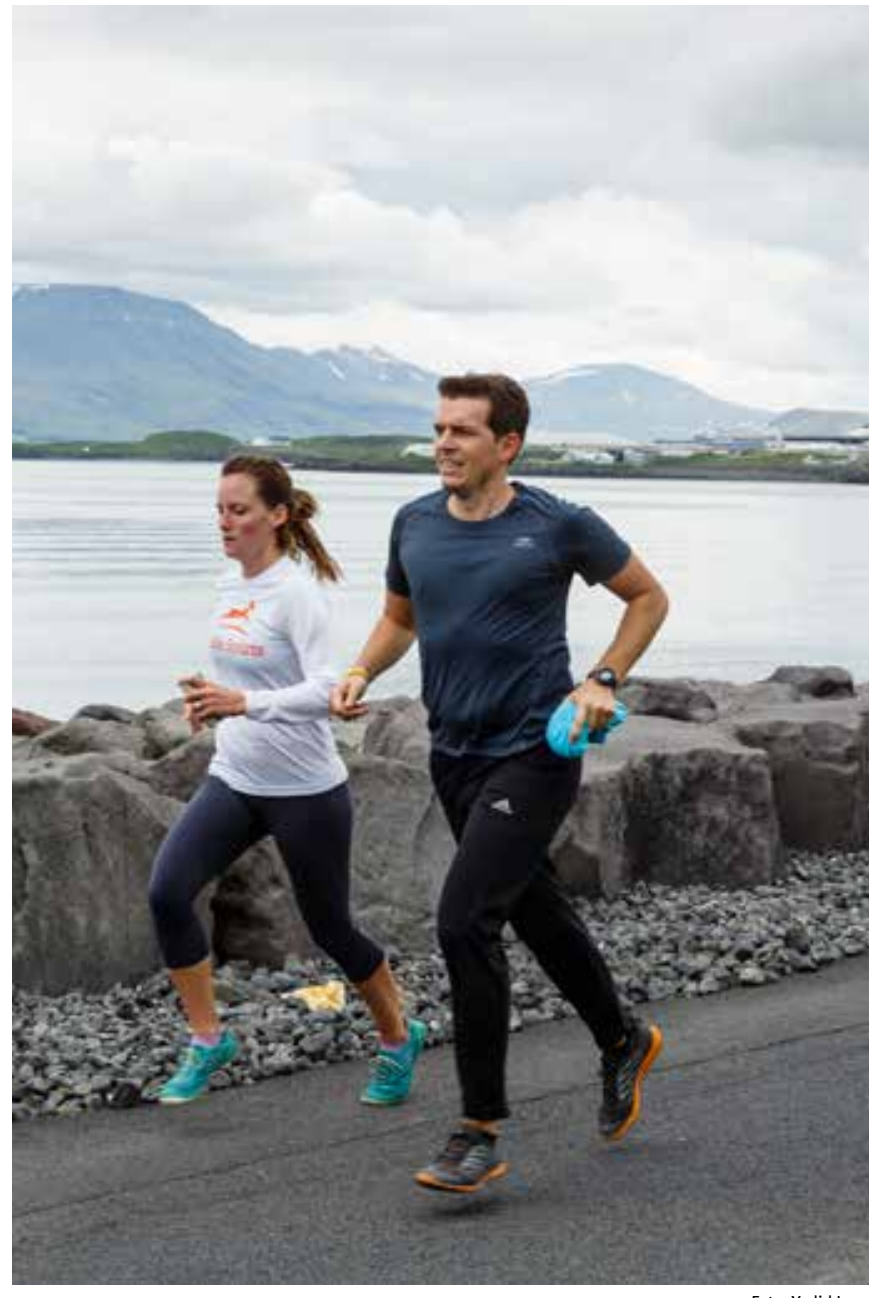

Foto: Yadid Ley 


\section{Health care expenditure}

The major part of health care expenditure is paid by the public sector. Data on health care expenditure are based on data from the $O E C D$, and its definition of health care expenditure differs somewhat from national definitions. The structural differences in the health care services of the individual countries also affect what is defined as a health cost.

In all Nordic countries, health and treatment expenditure account for about 9 to 12 per cent of the gross domestic product, GDP. Denmark is accounting for the highest share and the Faroe Islands and Finland for the lowest.

\section{Sjukvårdskostnader}

Den absolut största delen av sjukvårdskostnaderna betalas av den offentliga sektorn. Uppgifterna om sjukvårdskostnader är baserade på uppgifter från $\mathrm{OECD}$, och deras definition av sjukvårdskostnader skiljer sig något från de nationella definitionerna. Strukturskillnaderna i sjukvårdssystemen i de enskilda länderna påverkar också vad som inkluderas i sjukvårdskostnaderna.

Utgifterna för hälso- och sjukvård utgör i alla de nordiska länderna mellan 9 och 12 procent av bruttonationalprodukten, BNP.

Danmark står för den högsta andelen och Färöarna och Finland för den lägsta. Sjukvårdskostnader

Denmark

Euro per capita

\section{Total health care expenditure}

Public financing

Private financing

Per cent of total

health care expenditure

Public financing

Private financing

Per cent of GDP

Total health care expenditure

品 Heal12

Source: NOMESCO.

Note: Faroe Islands: 2009 data. Finland: Includes Åland.

Not: Füröarna: 2009 års uppoifter. Finland: Inkludera Åland.

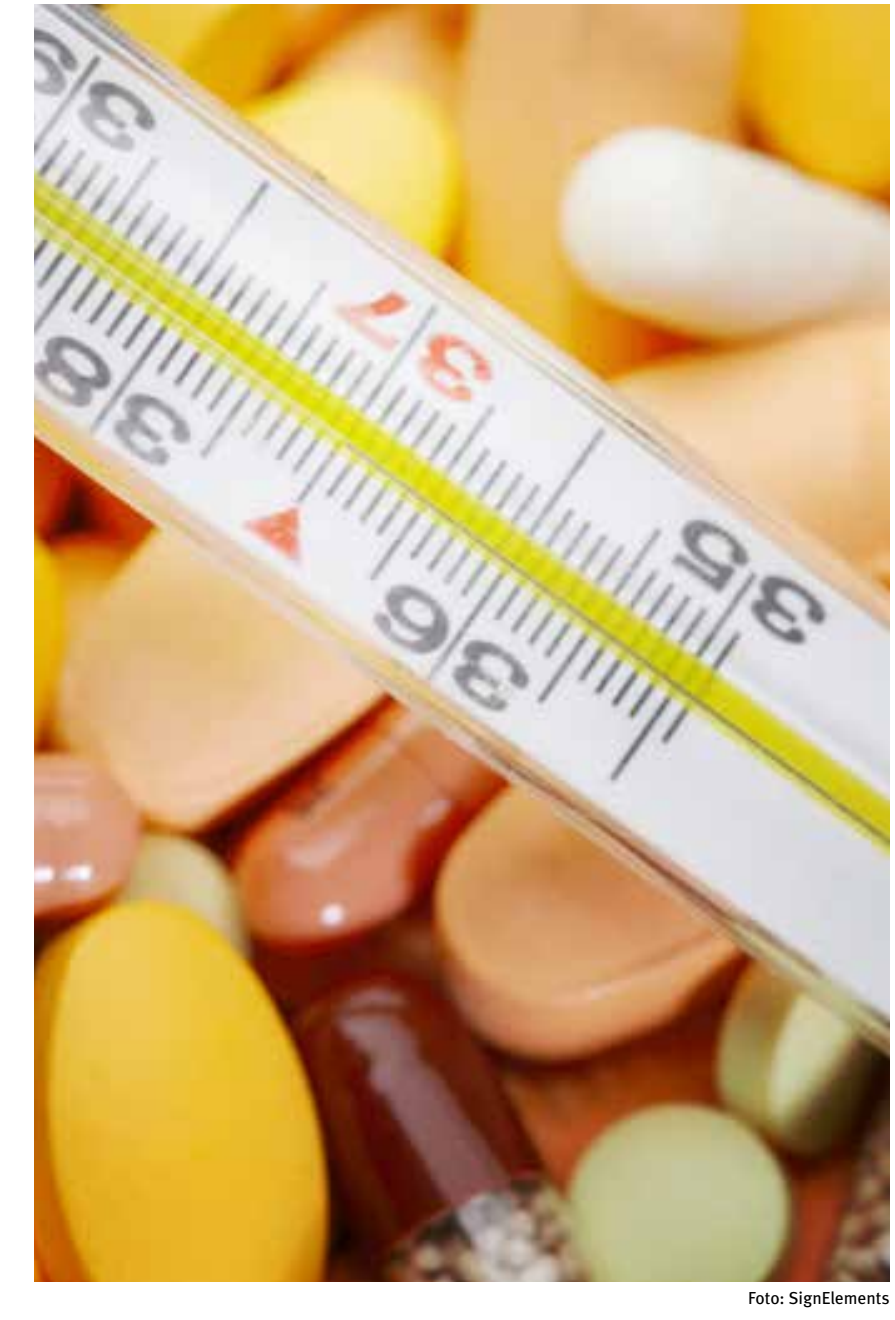

52 Health · Hälsa 


\section{Hospitals and health staff}

There is a general tendency in the Nordic countries to close down smaller hospitals and concentrate resources in fewer, but larger, hospitals.

Hospital beds are organized somewhat differently in Finland, Åland and Greenland than in the other countries. A number of beds are attached to health centres, and these beds appear in the tables as "other" beds. Some of these beds are for care of elderly people, and they are similar to beds in nursing homes and old peoples' homes in the other countries. This gives a larger number of beds in relation to the population than in the other countries.

Sjukhus och sjukvårdspersonal

Det finns en allmän tendens i de nordiska länderna att stänga mindre sjukhus och att koncentrera resurserna till färre men större sjukhus.
Sjukhussängar är organiserade något annorlunda i Finland, på Åland och Grönland än i de andra länderna. Ett antal bäddar är knutna till vårdcentraler, och dessa bäddar förekommer i tabellerna som "övriga" bäddar. Några av dessa sängar är för vård av äldre, och de motsvarar bäddar i vårdhem och ålderdomshem $\mathrm{i}$ de andra länderna. Detta ger ett större antal bäddar i förhållande till befolkningen än i de andra länderna.
Hospital beds by speciality. 2012

Antal vårdplatser på sjukhus efter specialitet

Denmark $\begin{array}{rr}\text { Faroe } & \text { Green- } \\ \text { Islands } & \text { land }\end{array}$ Green- Finland
land

Åland Iceland Norway Sweden

\section{Hospital beds}

per 100000

per 100000

Total

Somatic

wards

Psychiatry

Other

可 Heal17

Source: NOMESCO.

Note: Finland: Includes Åland.
Not: Finland: Inkluderar Åland.

\begin{tabular}{|c|c|c|c|c|c|c|c|c|}
\hline & \multicolumn{6}{|l|}{ andu } & \multirow[b]{2}{*}{$\begin{array}{r}\text { Vårdplatser på } \\
\text { sjukhus per } \\
100000 \\
\text { invånare }\end{array}$} \\
\hline & & & & & & & & \\
\hline 280 & 515 & 821 & 529 & 471 & 328 & 397 & 266 & $\begin{array}{r}\text { Totalt } \\
\text { Somatiska }\end{array}$ \\
\hline 229 & 400 & 184 & 165 & 197 & 230 & 234 & 220 & vårdavdelningar \\
\hline 51 & 114 & 21 & 69 & 48 & 46 & 121 & 46 & Psykiatri \\
\hline - &.. & 616 & 295 & 226 & 52 & 42 & - & Övrigt \\
\hline
\end{tabular}

Table 4.2

(1)

Active physicians and dentists. 2012

Figure 4.1

Aktiva läkare och tandläkare

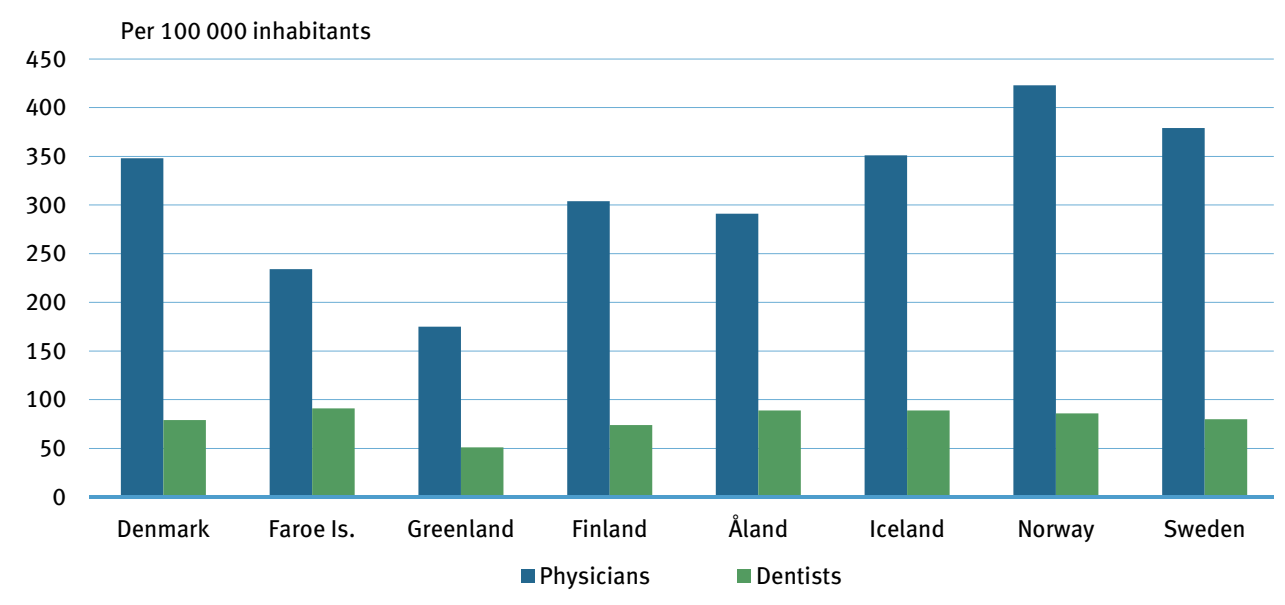

믄 Heal10

Source: NOMESCO.

Note: Denmark: 2010 data. Åland Iceland and Sweden: 2011 data.

Not: Danmark: 2010 års uppgifter. 


\section{Deaths}

In all countries, the mortality rate is higher for men than women, except for cardiovascular diseases where rates are at the same

level or even higher for women in some countries. Among causes of death, circulatory diseases and cancer account for the majority of deaths in all age groups - except for children - for both men and women. Mortality rates have generally declined for all the shown causes of death from 2005 to 2012 in all the Nordic countries.

The figures for the autonomous areas, the Faroe Islands (49 000 inhabitants), Greenland (56 000 inhabitants) and Åland (28 000 inhabitants) must be viewed with caution, because of their small populations in which just a few deaths significantly boost rates per 100000 persons.

Dödsfall

I alla länderna är dödlighetstalen högre för män än kvinnor, utom för hjärt- och kärlsjukdomar, där talen ligger på samma nivå eller till och med högre för kvinnor i vissa länder. Bland dödsorsakerna står hjärt- och kärlsjukdomar och cancer för huvuddelen av dödsfallen i alla åldersgrupper - utom för barn - för både män och kvinnor. Från 2005 till 2012 har dödlighetstalen i alla nordiska länder generellt sjunkit för de dödsorsaker som redovisas här.

Uppgifterna för de självstyrande områdena Färöarna (med 49000 invånare), Grönland (med 56000 invånare) och Åland (med 28000 invånare) måste tas med försiktighet, eftersom områdenas låga folkmängd gör att några få dödsfall drar upp siffrorna per 100000 invånare väsentligt.

\begin{tabular}{|c|c|c|c|c|c|c|c|c|c|}
\hline & Denmark & $\begin{array}{r}\text { Faroe } \\
\text { Islands }\end{array}$ & Greenland & Finland & Åland & Iceland & Norway & Sweden & \\
\hline Men & & & & & & & & & Män \\
\hline 2005 & & & & & & & & & 2005 \\
\hline Cancer & 300 & 206 & 218 & 215 & 310 & 193 & 224 & 256 & Cancer \\
\hline Cardiovascular diseases & 303 & 335 & 185 & 364 & 338 & 226 & 300 & 418 & Hjärt- och kärlsjukdomar \\
\hline Suicide & 17 & 12 & 89 & 28 & 23 & 16 & 16 & 19 & Självmord \\
\hline Accidents & 35 & 37 & 82 & 81 & 43 & 26 & 50 & 44 & Olyckor \\
\hline 2012 & & & & & & & & & 2012 \\
\hline Cancer & 287 & 182 & 208 & 232 & 279 & 192 & 229 & 242 & Cancer \\
\hline Cardiovascular diseases & 230 & 261 & 131 & 382 & 332 & 236 & 238 & 350 & Hjärt- och kärlsjukdomar \\
\hline Suicide & 16 & & 100 & 25 & 12 & 18 & 15 & 17 & Självmord \\
\hline Accidents & 24 & 63 & 60 & 63 & 61 & 25 & 39 & 36 & Olyckor \\
\hline Women & & & & & & & & & Kvinnor \\
\hline 2005 & & & & & & & & & 2005 \\
\hline Cancer & 276 & 212 & 225 & 189 & 198 & 152 & 213 & 227 & Cancer \\
\hline Cardiovascular diseases & 322 & 334 & 188 & 389 & 455 & 217 & 328 & 436 & Hjärt- och kärlsjukdomar \\
\hline Suicide & 6 & 1 & 86 & 10 & 5 & 6 & 7 & 8 & Självmord \\
\hline Accidents & 27 & 19 & 53 & 36 & 17 & 18 & 34 & 31 & Olyckor \\
\hline 2012 & & & & & & & & & 2012 \\
\hline Cancer & 256 & 201 & 227 & 200 & 242 & 160 & 203 & 218 & Cancer \\
\hline Cardiovascular diseases & 239 & 244 & 136 & 382 & 400 & 221 & 281 & 384 & Hjärt- och kärlsjukdomar \\
\hline Suicide & 5 & & 27 & 8 & 7 & 4 & 6 & 7 & Självmord \\
\hline Accidents & 16 & 13 & 38 & 33 & 21 & 16 & 34 & 25 & Olyckor \\
\hline
\end{tabular}

Deal03, Heal04, Heal05 and Healo7

Note: Denmark: 2005 data for Cancer and Cardiovascular diseases refer to 2006. Norway and Sweden: 2005 data for Accidents refer to 2004. Faroe Islands: Data for suicide: 2005 refers to 2006. Finland: Includes Äland. Faroe Islands, Greenland, Äland and Iceland: Cancer, Cardiovascular diseases and Accidents 2012 refer to 2009. Faroe Islands: Suicide 2012 refers to 2008. Greenland, Not: Danmark: 2005 års uppgifter för Cancer och Hjärt- och kärlsjukdomar avser 2006. Norge och Sverige: 2005 års uppgifter för Olyckor avser 2004. Färöarna: Uppgifter for Självmord: 2005 avser 2006 års uppgifter. Finland: Inkluderar Åland. Färöarna, Grönland, Åland och Island: 2012 ärs uppgifter för Cancer, Hjärt- och kärlsjukdomar och Olyckor avser 2009. Färöarna: Uppgifter för Självmord 2012 avser 2008. Grönland, Åland och Island: 2012 års uppgifter för Självmord avser 2009. 


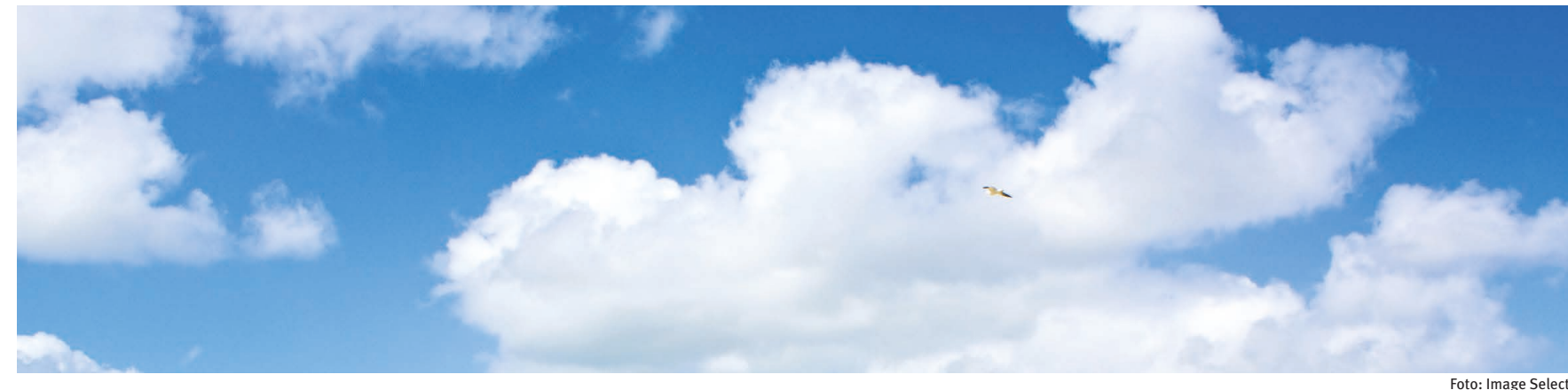

Confirmed new cases of cancer by sex

Figure 4.2 Bekräftade nya fall av cancer efter kö

\section{Confirmed new cases per million me}

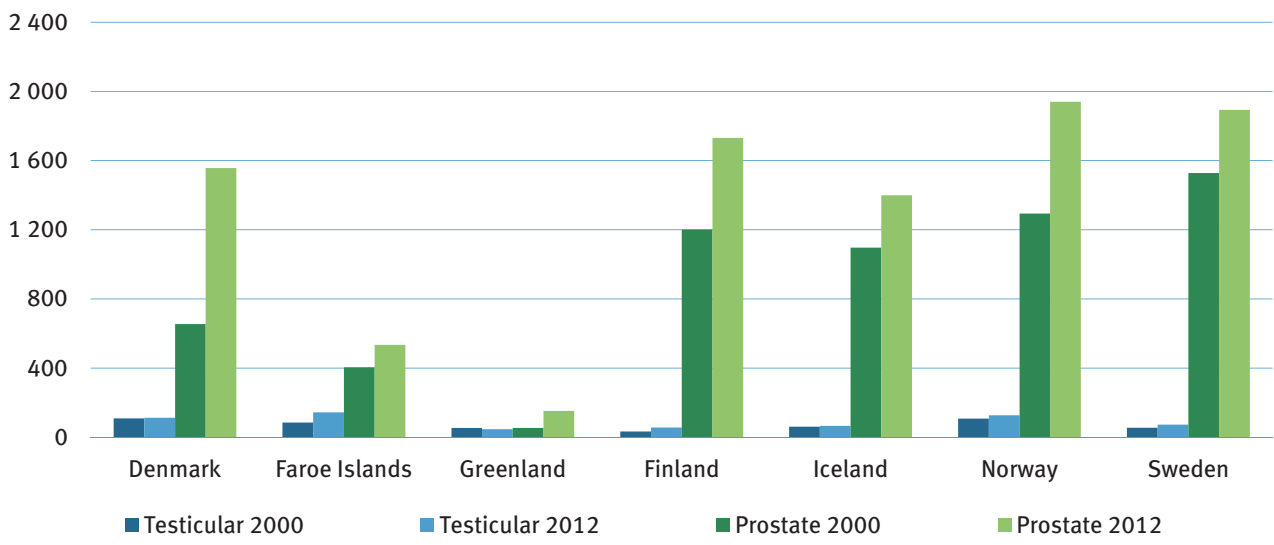

Confirmed new cases per million women

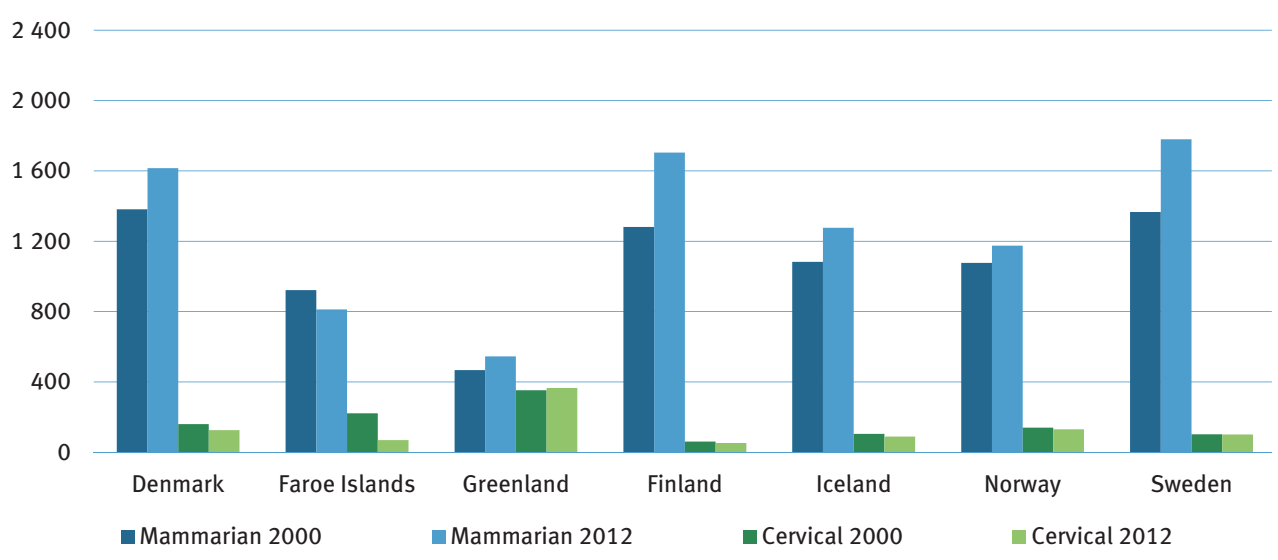

ㅁ. Heal18 and Heal19
Source: NOMESCO.

ote: Faroe Islands: 2011 refers to 2007. Greenland and Iceland: 2011 refers to 2009. Finland: Includes Åland.

Not: Färöarna: 2011 avser 2007 års uppgifter. Grönland och Island: 2011 avser 2009 ärs uppgifter. Finland: Inkluderar Åland. 


\section{Suicide}

The number of suicides has declined in all the Nordic countries over the latest 15 years. Distributed by age groups (disregarding Greenland), there seem to be considerably more suicides among older men in Finland and among older women in Denmark than in the rest of the Nordic countries.

The overall lowest suicide rates for men in the Nordic countries are found in the Faroe Islands, Denmark and Norway with 8.0, 15.8 and 14.7 per 100000 respectively. The lowest number of suicides among women in the Nordic countries are found in the Faroe Islands (0.9), Iceland (4.4) and Denmark (5.4). Greenland has the highest suicide rate for both men and women.
Självmord

Antalet självmord har minskat i alla de nordiska länderna under de senaste 15 åren. Åldersfördelat (bortsett från Grönland) verkar det som betydligt fler äldre män i Finland och äldre kvinnor i Danmark begår självmord än i övriga Norden.

De övergripande lägsta självmordssiffrorna för män i de nordiska länderna (utom de självstyrande områdena) finns på Färöarna, i Danmark och Norge med 8,0, 15,8 respektive 14,7 självmord per 100000 invånare. Det lägsta antalet självmord bland kvinnor i de nordiska länderna sker på Färöarna $(0,9)$, Island $(4,4)$ och i Danmark $(5,4)$. Grönland har den högsta självmordsfrekvensen både för män och kvinnor.
Health care expenditure. 2011 Sjukvårdskostnader

\begin{tabular}{|c|c|c|c|}
\hline & Denmark & $\begin{array}{r}\text { Faroe } \\
\text { Islands }\end{array}$ & Greenland \\
\hline \multicolumn{4}{|l|}{ Euro per capita } \\
\hline Total health care expenditure & 4522 & 2761 & 2797 \\
\hline Public financing & 3832 & .. & 2797 \\
\hline Private financing & 690 & .. & \\
\hline \multicolumn{4}{|l|}{$\begin{array}{l}\text { Per cent of total } \\
\text { health care expenditure }\end{array}$} \\
\hline Public financing & 84.7 & .. & 100.0 \\
\hline Private financing & 15.3 & .. & \\
\hline \multicolumn{4}{|l|}{ Per cent of GDP } \\
\hline Total health care expenditure & 10.5 & 8.3 & 9.0 \\
\hline
\end{tabular}

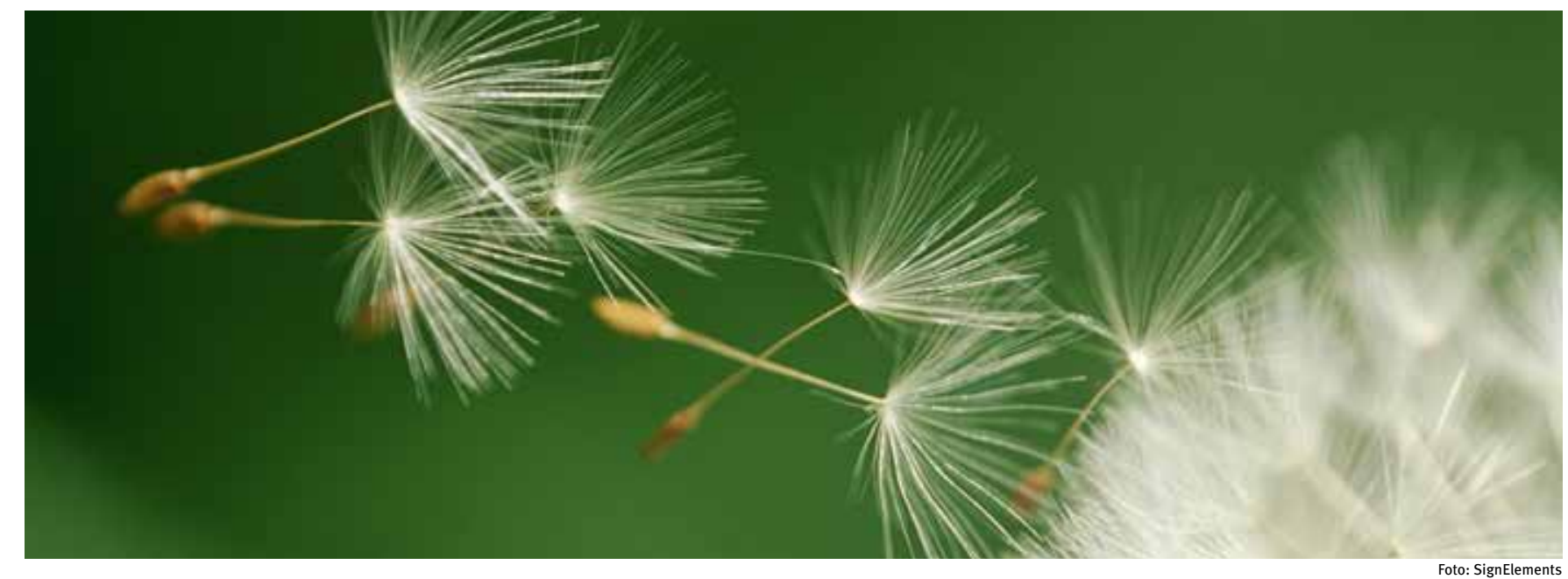

ㅁ Heal12

OMESCO.

Note: Faroe Islands: 2009 data. Finland: Includes Åland.
Not: Färöarna: 2009 års uppgifter. Finland: Inkluderar Äland 


\section{Alcohol}

Several of the Nordic countries have restrictions on sale of alcohol in order to keep consumption low. The level of consumption should be viewed with some caution as it only includes sale of beer, wine and alcohol. The figures indicate that the largest sale of alcohol is to be found in Denmark, Greenland and Finland.

\section{Alkohol}

Flera av de nordiska länderna har restriktioner på försäljning av alkohol för att hålla konsumtionen låg. Konsumtionsnivån bör ses med viss försiktighet, eftersom den endast omfattar försäljning av öl, vin och sprit. Siffrorna visar att den största försäljningen av alkohol finns i Danmark, på Grönland och i Finland.

\section{Smoking}

Although the number of smokers in the Nordic countries has been decreasing during recent years, there continues to be large differences in the number of smokers, both for men and for women and between countries. In the Faroe Islands and in Sweden, more women than men smoke. In the other countries more men than women smoke. The Faroe Islands have the highest number of daily smokers - both men and women. Sweden has the smallest number of daily smokers for men and Iceland for women.

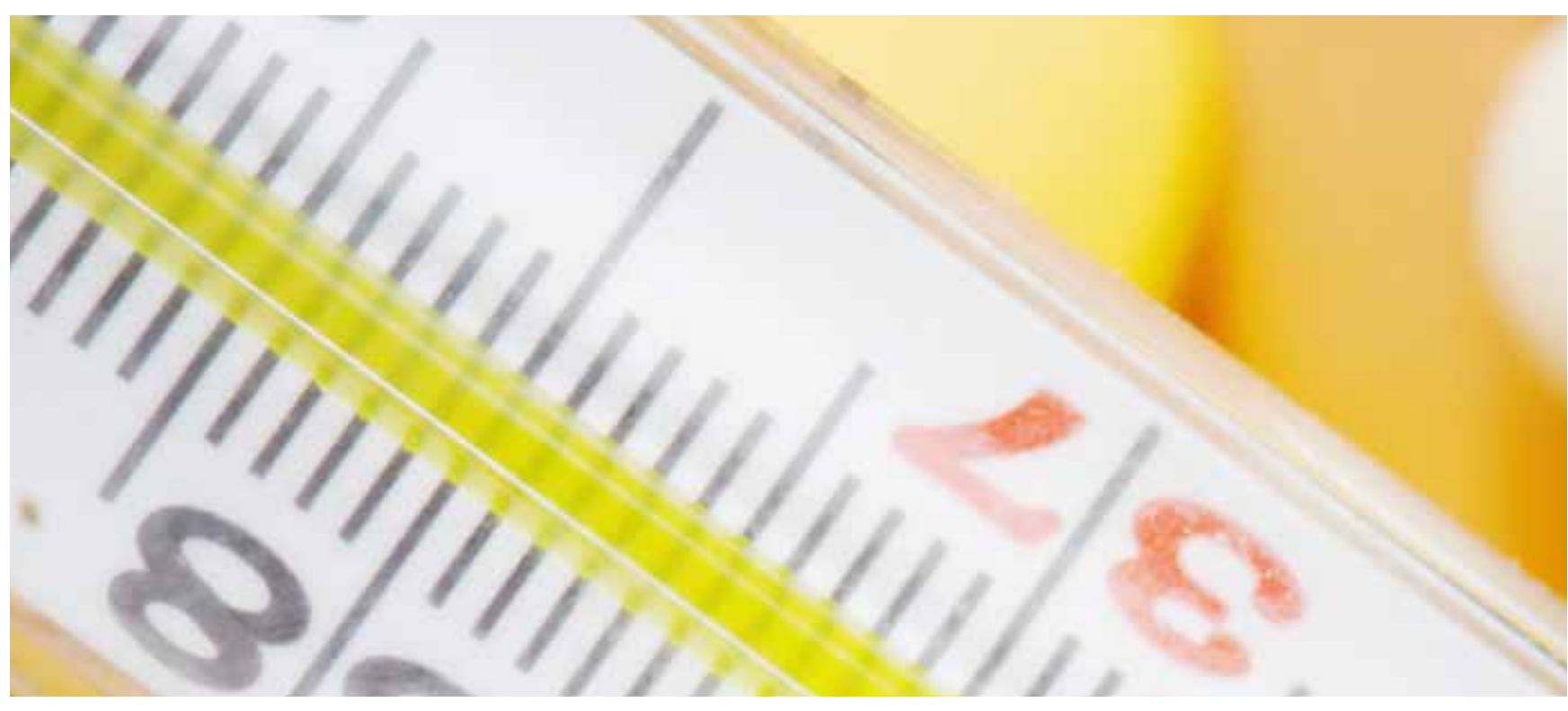

Rökning

Även om antalet rökare i de nordiska länderna har minskat under senare år är det fortfarande stora skillnader mellan antalet kvinnliga och manliga rökare och mellan länderna. På Färöarna och $\mathrm{i}$ Sverige röker fler kvinnor än män. I de andra nordiska länderna röker fler män än kvinnor. Det är flest som röker på Färöarna och det gäller både män och kvinnor. Sverige har den lägsta andelen män som röker dagligen och Island den lägsta andelen kvinnor som röker dagligen.

Daily smokers

Table 4.4 Personer som röker dagligen

Denmark Faroe Is. Finland Iceland Norway Sweden

$\begin{array}{lrrrrrrr}\begin{array}{l}\text { Per cent } \\ \text { Men }\end{array} & & & & & & & \begin{array}{r}\text { Procent } \\ \text { Män }\end{array} \\ 1995 & 44 & . . & 29 & 32 & 33 & 22 & 1995 \\ 2000 & 31 & . . & 27 & 23 & 31 & 17 & 2000 \\ 2005 & 28 & 28 & 26 & 20 & 27 & 14 & 2005 \\ 2012 & 17 & 27 & 21 & 15 & 15 & 13 & 2012 \\ \text { Women } & & & & & & & \text { Kvinnor } \\ 1995 & 39 & . . & 19 & 33 & 32 & 24 & 1995 \\ 2000 & 26 & . . & 20 & 22 & 32 & 21 & 2000 \\ 2005 & 23 & 27 & 18 & 20 & 24 & 18 & 2005 \\ 2012 & 17 & 28 & 18 & 13 & 14 & 15 & 2012 \\ \text { DHeal01 } & & & & & & & \\ \text { Source: NOMESCO. } & & & & & & & \end{array}$




\section{Social integration and income} Social integration och inkomst

The core values in the Nordic welfare states are equal opportunities, social solidarity and security for all. The model promotes social rights and the principle that everyone is entitled to equal access to social and health services, education and culture. This also applies to care for social outcasts and vulnerable groups in society. One key objective is to create opportunities for all to take part in civic life and in society's decision-making processes.

The Nordic societies prioritise preventative and supportive initiatives for vulnerable groups and their families, particularly for socially vulnerable children and young people.
Kärnvärderingarna i det nordiska välfärdssamhället är lika möjligheter, social solidaritet och trygghet för alla. Det handlar om sociala rättigheter och principen att alla ska ha lika tillgång till sociala tjänster och hälsovård, utbildning och kultur. Det gäller också omsorgen för socialt utsatta och sårbara grupper i samhället. Ett centralt mål är att göra det möjligt för alla att delta i samhällslivet och i samhällets beslutsprocess.

De nordiska samhällena prioriterar förebyggande och stödjande insatser för utsatta grupper och deras familjer, i synnerhet socialt utsatta barn och ungdomar.

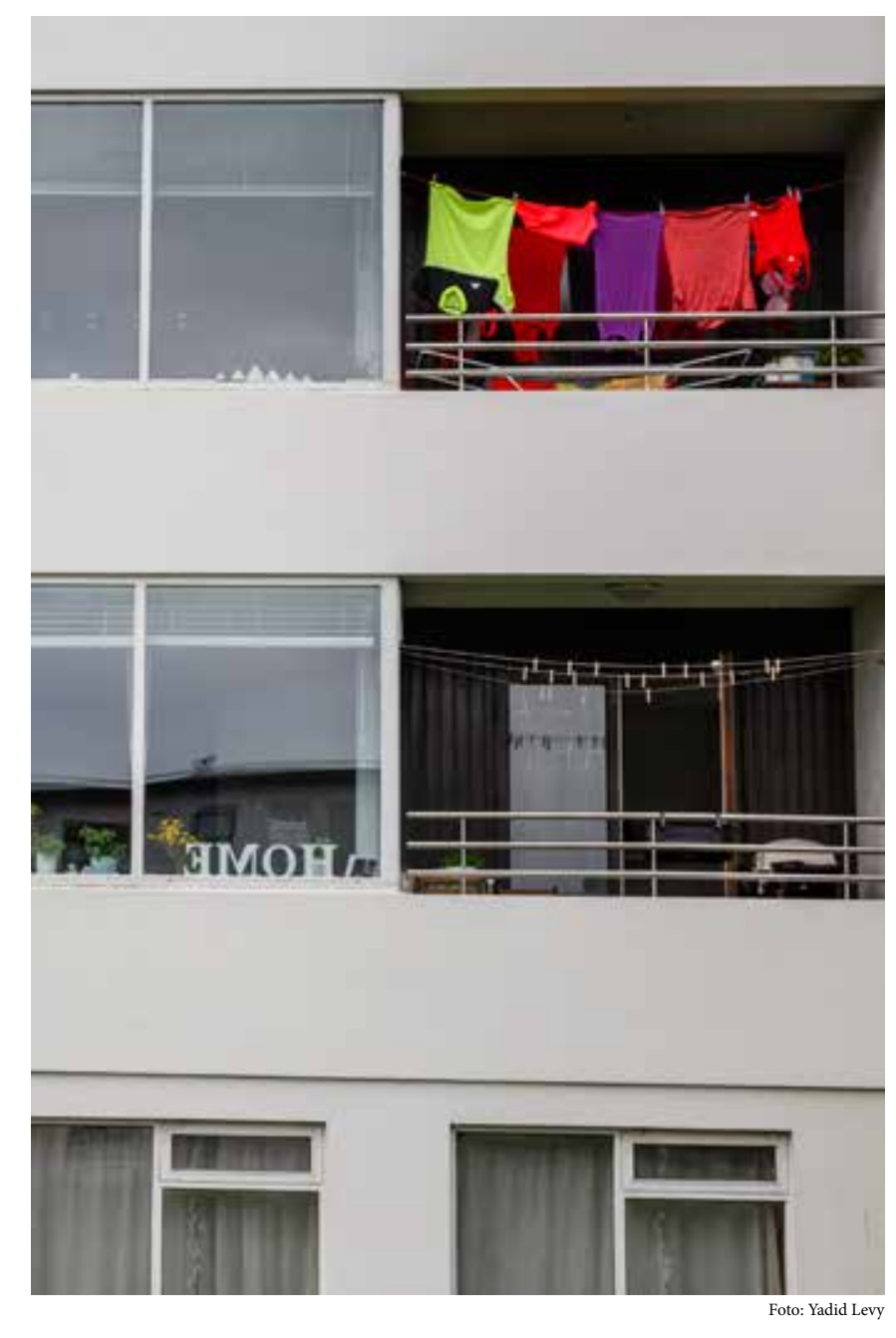




\section{Inequality and risk of poverty}

The Gini coefficient is the most commonly used measure of inequality. The coefficient varies between 0 , which reflects complete equality and 1 , which indicates complete inequality - meaning one person has all the income or consumption, all others have none. All the Nordic countries are considered to be very equal societies.

The risk of poverty is often measured as a percentage of the population with an income under 50 or 60 per cent of the median income. In the Nordic countries between 4.8-7.8 per cent of the households live with a risk of poverty - i.e. have an income under 50 per cent of the median income.
Ojämlikhet och fattigdom

Gini-koefficienten är det vanligaste måttet på ojämlikhet. Koefficienten varierar mellan 0 , vilket avspeglar fullständig jämlikhet och 1, vilket betyder fullständig ojämlikhet - det vill säga att en person har alla inkomster eller all konsumtion, alla andra har ingen. Alla de nordiska länderna anses vara mycket jämlika samhällen.

Risken för fattigdom mäts ofta som andel av befolkningen med en inkomst under 50 eller 60 procent av medianinkomsten. I de nordiska länderna lever mellan 4,8 och 7,8 procent av hushållen med en risk för fattigdom - det vill säga att de har en inkomst under 50 procent av medianinkomsten.
Risk of poverty. 2012

Risk för fattigdom

$\begin{array}{rrr}\text { Denmark } & \text { Finland } & \text { Icela } \\ & & \\ & & \\ & & \\ 7.7 & 6.0 & 4.8 \\ 5.0 & 11.8 & 3.7 \\ 12.6 & 10.5 & 16.7 \\ 3.9 & 4.1 & 3.0 \\ 2.3 & 1.6 & \\ 3.6 & 3.1 & \\ & & \end{array}$

\begin{tabular}{lr} 
& Denmark \\
\hline $\begin{array}{l}\text { Per cent of total population living in } \\
\text { households with an income under } 50 \\
\text { per cent of the median of the equivalent } \\
\text { disposable income }\end{array}$ & \\
\hline Households, total & \\
One adult older than 65 years & 7.7 \\
Single parent with dependent children & 5.0 \\
Two adults younger than 65 years & 12.6 \\
Two adults, at least one aged 65 years & 3.9 \\
Two adults with dependent children & 2.3 \\
\hline
\end{tabular}

Table 5.1

므 Riop01

Source: Eurostat.

Ther states of the European Union as per 1 January 2013.

Not: EU27: De 27 medlemsstaterna i Europeiska unionen per 1 januari 2013.

\section{Gini-koefficienten}

Gini-coefficient

0.35

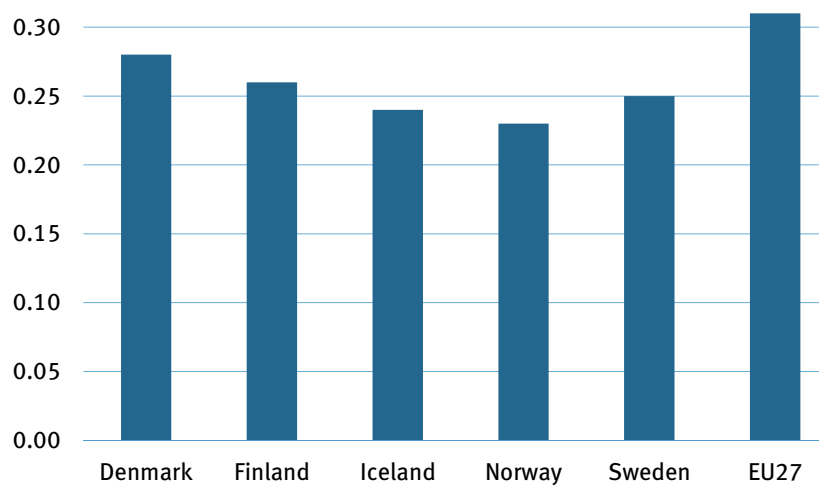

口Ginio1

Note: EU27: The 27 member states of the European Union as per 1 January 2013.

Not: EU27: De 27 medlemsstaterna i Europeiska unionen per 1 januari 2013. 


\section{Social assistance}

In all Nordic countries, social assistance is granted if all other support options have been exhausted. It is either given as a replacement for other personal income or as a supplement for low income. The assistance is individual and granted according to needs to meet the cost of living. In Denmark and Iceland, social assistance is taxable; in the other countries it is tax-free.

The Faroe Islands have the smallest proportion of recipients of social assistance, compared to the number of people by age

group ( 2.5 per cent). Finland has the highest share with more than 6 per cent.

Recipients of social assistance Figure 5.2 Mottagare av ekonomiskt bistån

Per cent of population $18+$ years

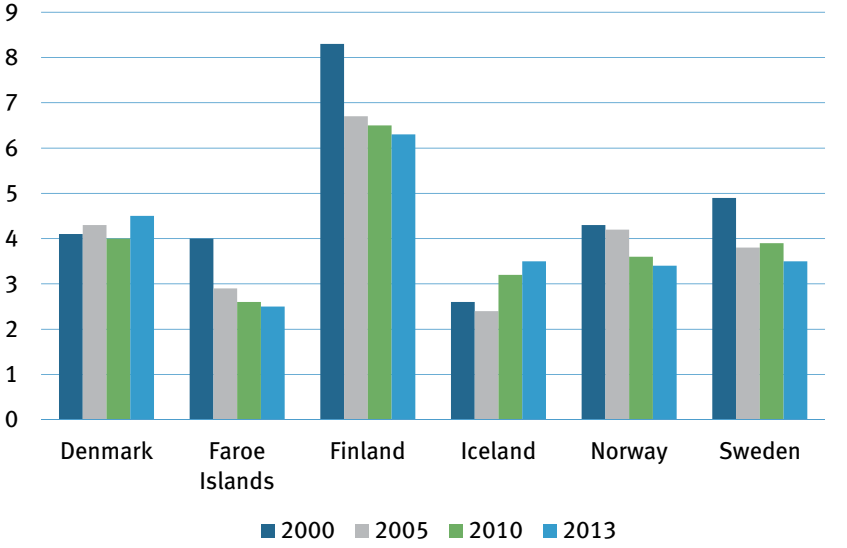

모 Soci12

Source: NOSOSCO.

2011 data. Finland and Norway: 2012 data.

Not: Färöarna: 2011 års uppgifter. Finland och Norge: 2012 års uppgifter.
In Iceland and Norway, relatively more persons live in old people's homes or in corresponding homes with nursing functions than in the rest of the Nordic countries. This is especially true of older age groups.

\section{Ekonomiskt bistånd}

I alla nordiska länder lämnas ekonomiskt bistånd om alla andra understödsmöjligheter har uttömts. Det lämnas antingen som en ersättning för annan privat inkomst eller som ett tillägg till en låg inkomst. Hjälpen är individuell och lämnas efter behov för att

People living in institutions or service housing. 2012 Personer på institutioner eller i serviceboende

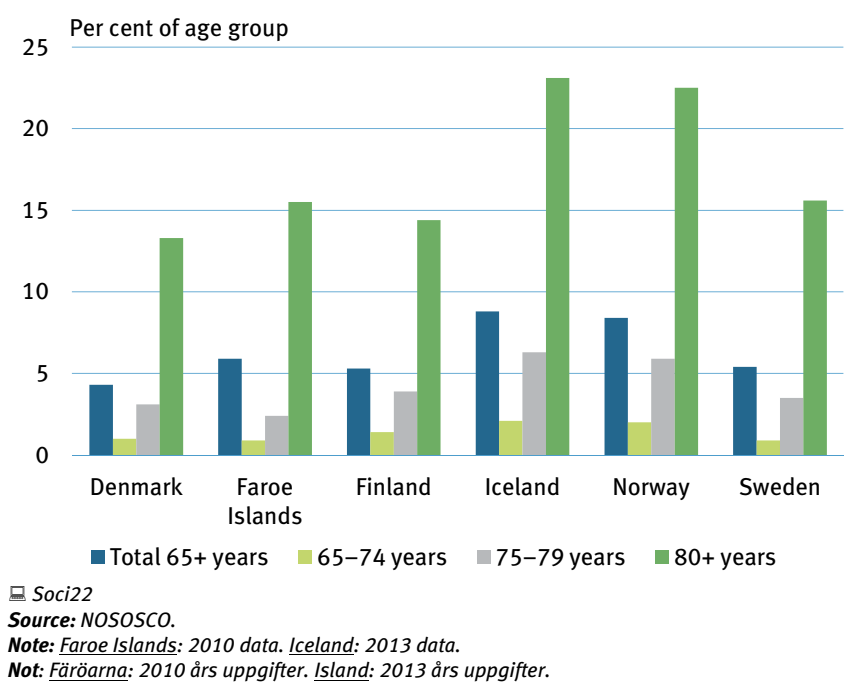

täcka levnadskostnaderna. I Danmark och på Island är ekonomiskt bistånd beskattningsbart, i de andra länderna är det skattefritt.

Färöarna har den minsta andelen mottagare av ekonomiskt bi-

stånd mätt i proportion till den vuxna befolkningen ( 2,5 procent) Finland har de högsta siffrorna med över 6 procent.

På Island och i Norge bor förhållandevis fler personer på vårdhem eller i någon annan typ av institutionsliknande boende med vårdservice än i övriga Norden. Det gäller i synnerhet de äldre åldersgrupperna.

Social expenditure by financial source 2012

Figure 5.4 Sociala utgifter efter finansieringskälla

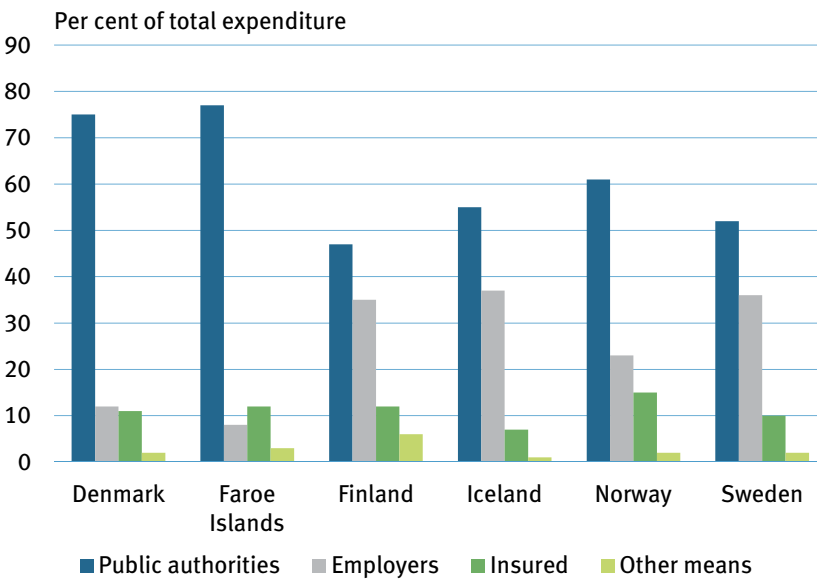
Soex06 Source: NOSOSCO 


\section{Pensions}

Pensions guarantee all citizens a certain level of income in connection with retirement (old age), disability or loss of a provider. In all the Nordic countries, a pension is payable to the elderly. Persons with a totally or partially reduced working capacity may also be granted a pension. In Denmark and the Faroe Islands, it is called anticipatory pension; in Finland, disability pension; and Iceland, invalid pension; in Norway, disablement pension; and in Sweden, sickness compensation.

\section{Pensioner}

Pensioner garanterar alla medborgare en viss inkomstnivå i samband med ålderspensionering, invalidisering eller förlust av försörjare. I alla de nordiska länderna betalas en pension ut till de gamla. Personer med helt eller partiellt nedsatt arbetskapacitet kan också beviljas pension. I Danmark och på Färöarna kallas det förtidspension, i Finland och på Island invalidpension, i Norge handikappension och i Sverige sjuk- och aktivitetsersättning.
Denmark Faroe Islands

Per cent of age group

Total

$16-39$ years

40-49 years

$50-54$ years

$55-59$ years

$60-64$ years

$65-66$ years

$67+$ years

$\begin{array}{rr}\mathbf{2 8} & \mathbf{2 2} \\ 2 & 1 \\ 7 & 4 \\ 11 & 7 \\ 14 & 10 \\ . . & 18 \\ 93 & 27 \\ 99 & 98\end{array}$

$\begin{array}{rr}22 & 32 \\ 1 & 2 \\ 4 & 5 \\ 7 & 9 \\ 10 & 16 \\ 18 & . \\ 27 & 98 \\ 98 & 105\end{array}$

a socio7

Note: Does not ind surviving spouse's pension, orphan's pension and part-time pension. As it is possible in all the countries to live outside the country in question and receive pension at the same time, he number of recipients may exceed 100 per cent. Faroe Islands: 2011 data. Iceland: 2012 data.

leva utanför landet i fråga och få pension samtidigt, kan antal mottagare överstiga .

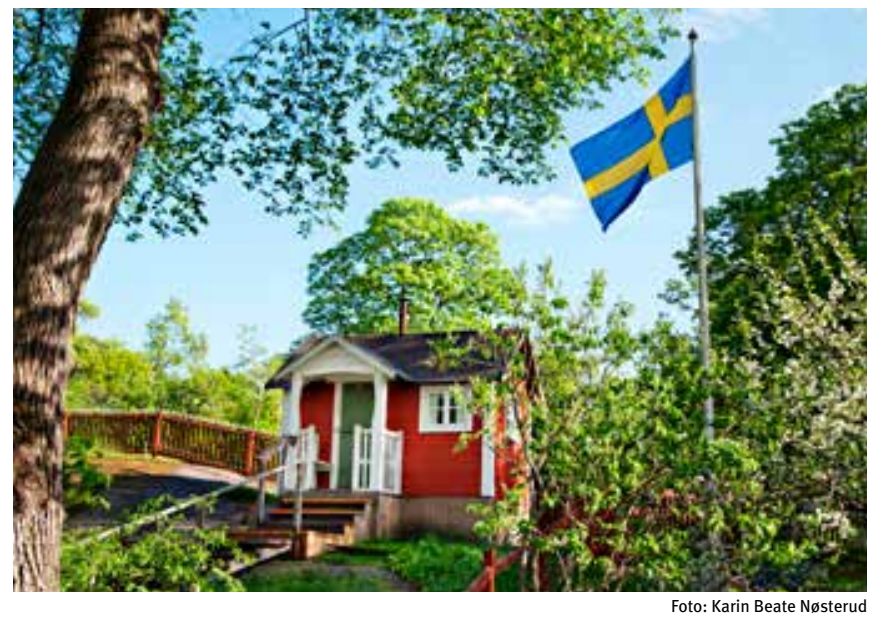

Foto: Karin Beate Nøsteru 


\section{Absence from work due to sickness}

In principle, everyone with gainful employment is entitled to daily cash benefits in the event of sickness. The structures vary considerably from country to country. In Denmark and Iceland, many people are entitled to full salary during illness. In Denmark, this only includes people employed in the public sector and some private sector employees. Benefits paid in connection with illness are taxable in all countries.

Absence from the workplace due to sickness for more than one week is markedly higher in Norway, compared with the other Nordic countries. Iceland has the lowest absence due to sickness in 2013. Women's absence due to sickness is generally higher than that of men.

\section{Sjukfrånvaro}

I princip har alla med inkomst av anställning rätt till dagligt understöd vid sjukdom. Strukturerna varierar väsentligt från land till land. I Danmark och på Island har många rätt till full lön vid sjukdom. I Danmark gäller detta endast personer som är anställda inom den offentliga sektorn och vissa anställda i den privata sektorn. Förmåner som betalas ut i samband med sjukdom beskattas i alla länder.

Sjukfrånvaro som varar mer än en vecka är mycket vanligare i Norge än i de andra nordiska länderna. För 2013 finner man den lägsta sjukfrånvaron i Island. I samtliga länder är kvinnornas sjukfrånvaro högre än männens.

\section{Percentage of all people employed}

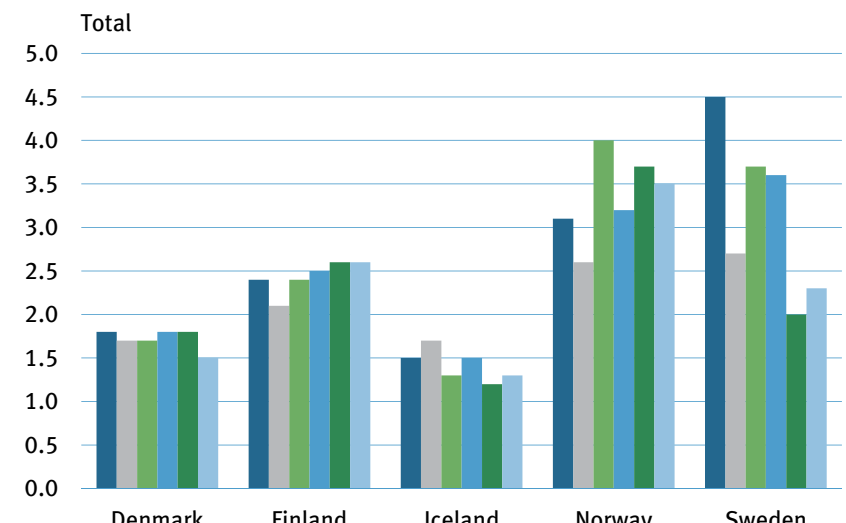

Denmark Finland

celand

Norway

Sweden

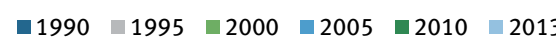

By sex. 2013

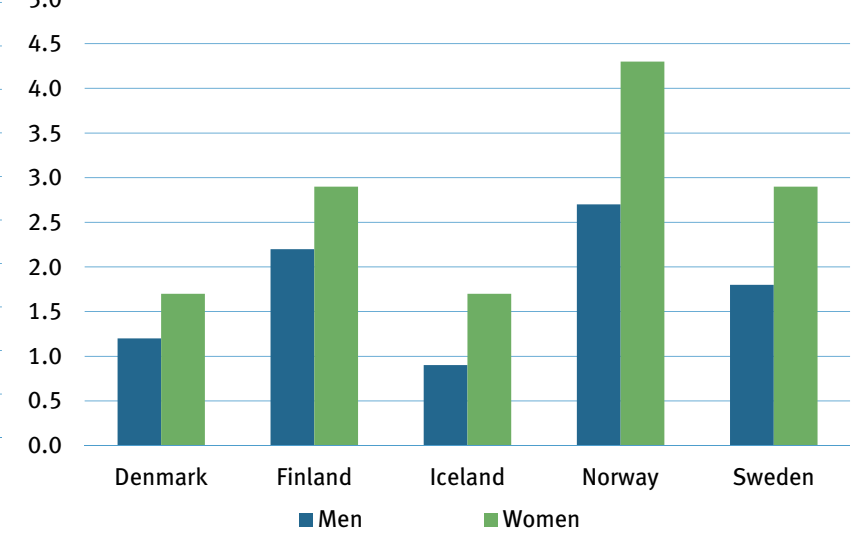

aSocio2

Note: The figures have been calculated on the basis of labour force surveys as an average of the censuses. Denmark: 15-66 years. Finland: 15-64 years. Iceland: 1990 figures refer to 1991. Not: Uppgifterna har beräknats utifrån arbetskraftsundersökningar som ett genomsnitt för hela antalet. Danmark: 15-66 år. Finland: 15-64 ăr. Island: 1990 års uppgifter avser 1991 . 


\section{Child care}

A characteristic feature in the Nordic countries is the high rate of both parents participating in the labour force. This increases the need for child care options during working hours.

Thus, most children between the ages of 3 and 5 are in institutions. With the exception of Finland, between 92 and 97 per cent of all children between the ages of 3 and 5 are in kindergartens or similar institutions. In Finland the proportion is 74 per cent. The percentage is generally much lower for children between 0 and 2 .

\section{Barnomsorg}

Ett utmärkande drag i de nordiska länderna är den höga andel av familjer som har båda föräldrar i arbetskraften. Detta ökar behovet av barntillsynsmöjligheter under arbetstid.

De flesta barn mellan 3 och 5 år finns således inom barnomsorgen. Med undantag av Finland är mellan 92 och 97 procent av alla barn mellan 3 och 5 år på förskola eller liknande inrättningar. I Finland är andelen 74 procent. Procentandelen är generellt mycket lägre för barn mellan 0 och 2 år.

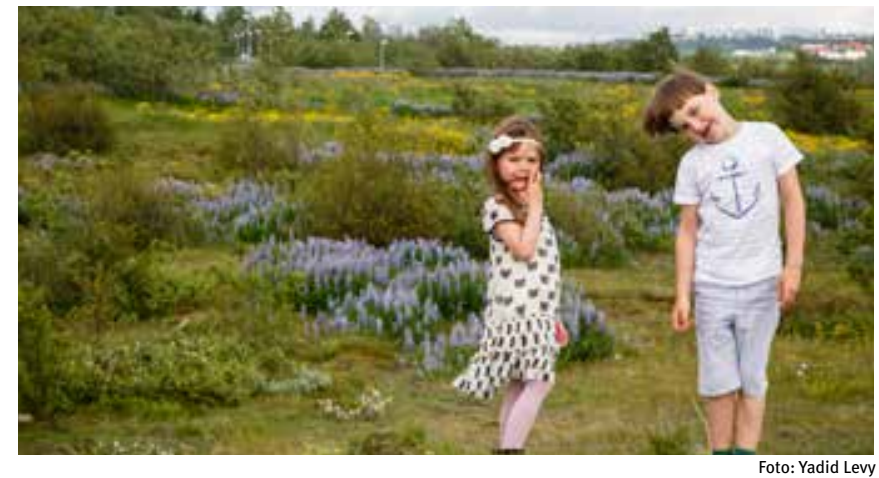

Foto: Yadid Levy 3-5-year-old children in day care 3-5-åriga barn i barnomsorg

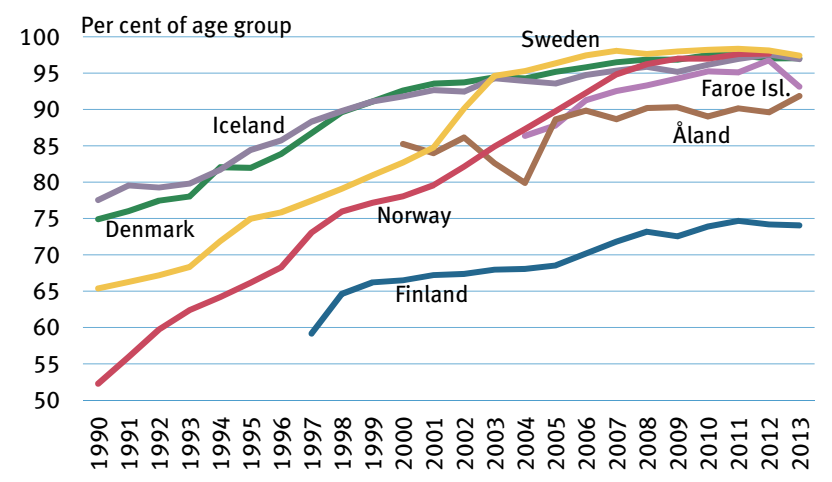

$\square$ Chil03 and Popu02

Source: National statistical institutes and National Institute for Health and Welfare, Finland. Note: Includes children in publicly funded private day-care. Finland: Includes Âland.

Norway: Includes children in private kindergartens.

Finland: Inkluderar Åland. Norge: Inkluderar barn i privata daghem.

Figure 5.6
Children and young people placed outside their homes. 2012

Table 5.3 Barn och unga som placerats utanför hemme

\begin{tabular}{|c|c|c|c|c|c|c|}
\hline & Denmark & Finland & Iceland & Norway & Sweden & \\
\hline Per 1000 of age group & & & & & & Per 1000 av åldersgrupp \\
\hline $0-6$ years & 4.1 & 7.5 & 1.2 & 6.0 & 4.6 & $0-6 \mathrm{år}$ \\
\hline $7-14$ years & 9.8 & 13.8 & 2.6 & 12.0 & 9.0 & $7-14$ år \\
\hline $15-17$ years & 22.8 & 28.7 & 11.6 & 23.0 & 33.9 & $15-17 \mathrm{ar}$ \\
\hline
\end{tabular}

$15-17$ years

믄 Soci27 NOSOSCO

Note: Includes children placed outside their homes with or without the consent of their parents. The statistics cover a variety of placements such as foster care, residential

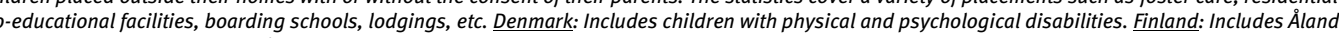
Iceland: Age groups: 0-6 years, 7-12 years and 13-16 years. pedagogiska utbildningsinstitutioner, internatskolor, egna bostäder m.m. Danmark: Inkluderar barn med fysiska och psykiska funktionshinder. Finland: Inkluderar Åland. Island: Äldersgrupper: 0-6 år, 7-12 år och 13-16 år. 


\section{Maternity day benefits}

More and more men make use of the leave schemes in connection with childbirth or adoption. However, both the number of recipients and the number of days in which maternity benefit is payable vary considerably from one country to another.

Iceland is in the lead with 28.5 per cent of the number of days taken by the father. In Iceland legislation on parental leave grants fathers, like mothers, an independent entitlement to paternity leave for 13 weeks. In Finland men are the most reluctant to take leave -8.8 per cent of the number of days were taken by men in Finland.

Havandeskaps- och föräldrapenning

Fler och fler män tar föräldraledighet i samband med sina barns födelse eller vid adoption. Men både antalet mottagare och antalet dagar då havandeskaps- och föräldrapenning tas ut varierar avsevärt från land till land.

När det gäller andel dagar uttagna av fadern ligger Island i täten med 28,5 procent. På Island innebär lagstiftning om föräldraledighet att pappor, liksom mammor, beviljades rätt till 13 veckors föräldraledighet. I Finland är män mest ovilliga att ta ledigt - andelen dagar som togs ut av män var 8,8 procent i Finland. Havandeskaps- och föräldrapenning vid graviditet, förlossning och adoption

\section{Number of days (1 000s)}

with maternity/paternity day benefits

Denmark

Finland

Iceland

Norway

Sweden

2000

Total number of days

Number of days per capita

Percentage taken by men

13150

(20)

rand

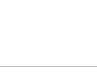

Antal dagar (1 000-tal) med
och havandeskapspenning föräldra- och havandeskapspenning

2013

Number of days per capita

Percentage taken by men

$\begin{array}{rrr}13150 & 15232 & 696 \\ 2.5 & 2.9 & 2.5 \\ 5.5 & 4.2 & 2.9 \\ & & \\ 16538 & 16445 & 1062 \\ 2.9 & 3.0 & 3.3 \\ 10.2 & 8.8 & 28.5\end{array}$

696
2.5
2.9

1062
3.3
28.5

11152
2.4

37100
4.2

Totalt antal dagar Antal dagar per invånare
Procent uttagna av män

2013

Totalt antal dagar Antal dagar per invânare

$\begin{array}{rrr}12763 & 52496 & \text { Totalt antal dagar } \\ 2.5 & 5.5 & \text { Antal dagar per invånare } \\ 21.2 & 25.1 & \text { Procent uttagna av män }\end{array}$

모 Socio

Source: NOSOSCO.
Note: Sweden: 2012 data.
Not:

Not: Sverige: 2012 arrs uppgifter.

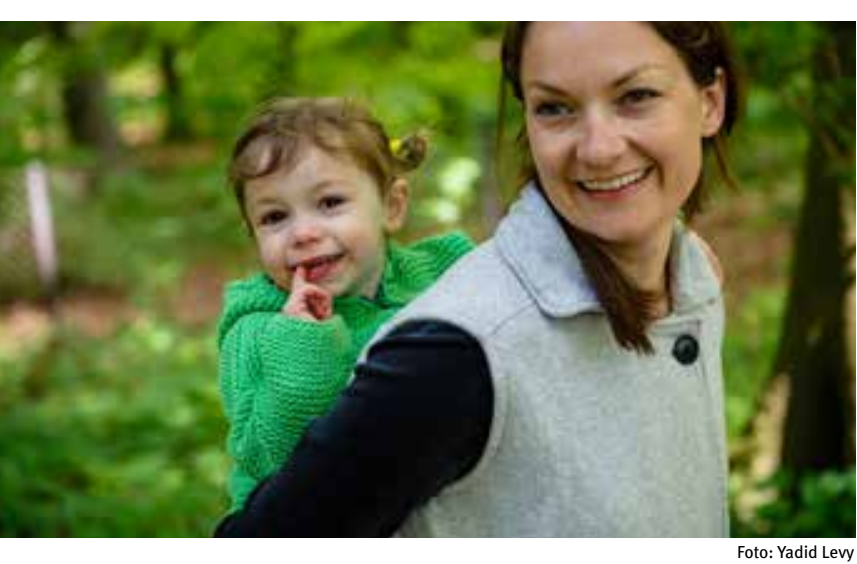

Did you know that ... mothers have become much older since the beginning of the sixties. Most babies are now born by mothers in the age group 30-34 years. In the beginning of the sixties most women were between 20 and 24 years of age when they gave birth.
Visste du att ... mödrarna har blivit mycket äldre sedan början av sextiotalet. De flesta barn är nu födda av mödrar i åldersgruppen 30-34 år. I början av sextiotalet var de flesta kvinnor mellan 20 och 24 år när de födde sina barn. 


\section{Income}

The Nordic countries differentiate themselves from other countries by combining high standards of living and a relatively even distribution of income. However, the financing of the Nordic welfare model entails a heavy tax burden and a major redistribution of income, compared with most other countries in the world.

The level of income is generally high and differences in the income level relatively small in the Nordic countries compared with other OECD countries. Generally, households with the lowest disposable incomes also receive the largest proportion of social benefits in relation to their gross income.
Inkomst

De nordiska länderna skiljer sig från andra länder genom att kombinera högt välstånd och en relativt jämn inkomstfördelning. Men finansieringen av den nordiska välfärdsmodellen medför en tung skattebörda och en väsentlig omfördelning av inkomsten jämfört med de flesta andra länder i världen.

Inkomstnivån är allmänt sett hög och skillnaderna i inkomstnivå relativt små i de nordiska länderna jämfört med andra OECDländer. I allmänhet tar hushållen med den lägsta disponibla inkomsten också emot störst andel sociala förmåner i relation till sin bruttoinkomst.

Equivalised median income per household. 2013

Figure 5.7 Ekvivalerad median inkomst per hushål

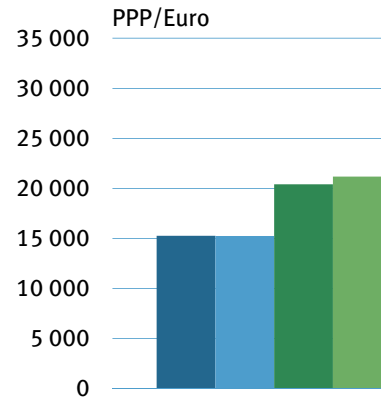

Denmark

Single person

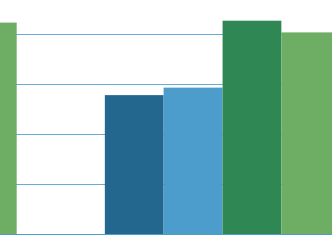

Finland

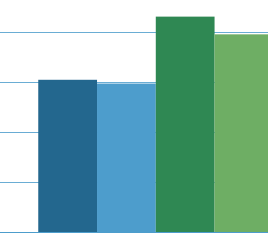

Iceland

- Two adults

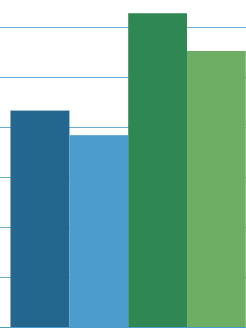

Norway

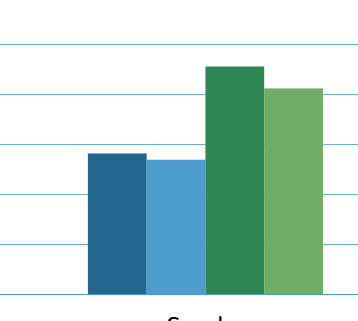

Sweden
- Two or more adults with dependant children

믄 Inco02

Note: Equivalised income is defined as the household's total disposable income divided by its "equivalent size", to take account of the size and composition of the household, and is attributed to each household member. Sweden: 2012 data. 


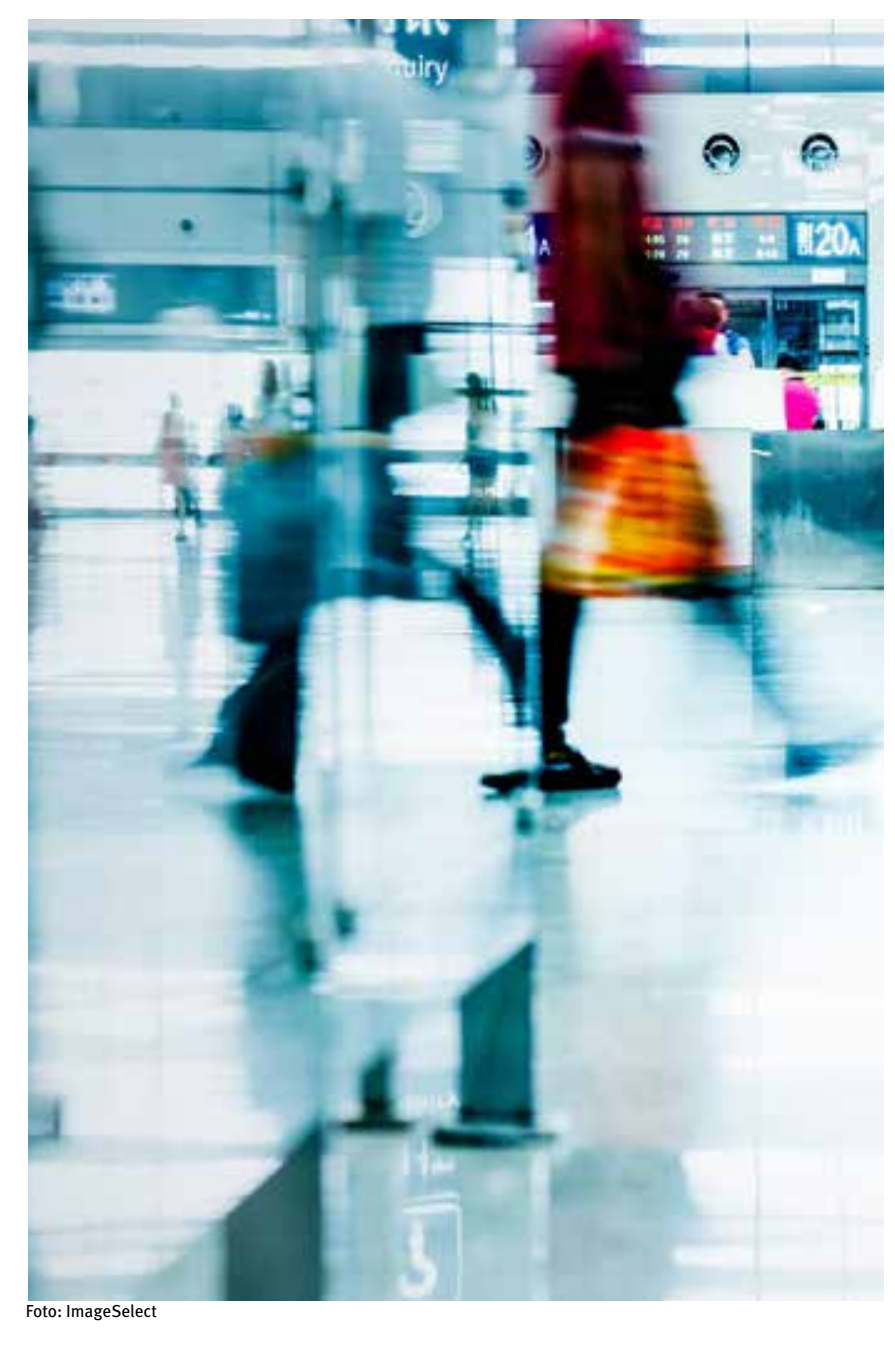

\section{Income by sex}

The Nordic countries play a leading part with regard to equality of the sexes. This can be ascertained by looking at women's access to education, health, political power and economic participation/equal pay. However, there are still differences in the pay for the same job performed by men and women respectively.

The greatest difference between men's and women's pay is seen in Sweden, while the greatest equality of the sexes is accounted for by Denmark, if equivalised disposable income is applied as measurement.
Inkomst efter kön

De nordiska länderna spelar en ledande roll när det gäller jämställdhet mellan könen. Detta kan konstateras genom att titta på kvinnors tillgång till utbildning, hälsa, politisk makt och ekonomiskt deltagande/lika lön. Men det finns fortfarande skillnader i mäns respektive kvinnors lön för samma arbete.

Mätt i ekvivalerad disponibel inkomst ses den största skillnaden mellan mäns och kvinnors löner i Sverige, medan Danmark har den största jämställdheten.

Average equivalised disposable income by sex

Figure 5.8

Genomsnittlig ekvivalerad disponibel inkomst efter kön

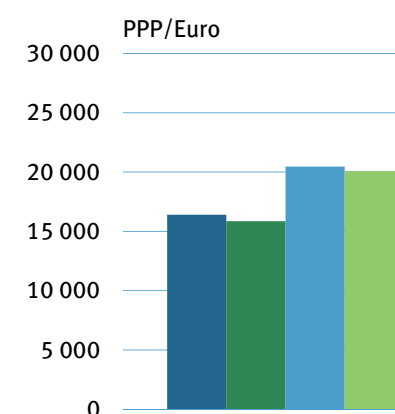

Denmark

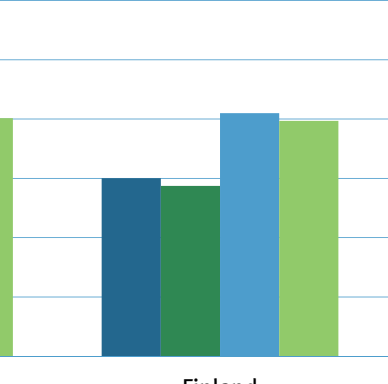

Finland

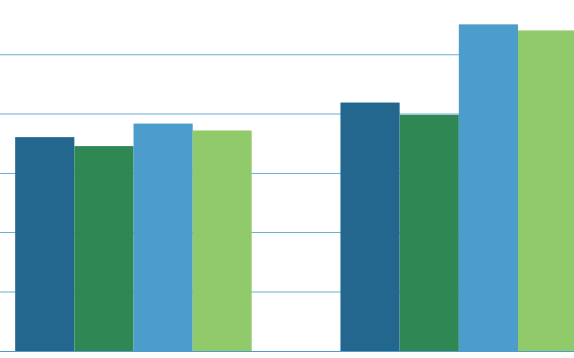

Iceland
Norway

믄o03

Source: Eurostat.

Woe The currency is converted from national currency to euro in Purchasing Power Standards (PPS), which eliminates the impact of differences in price levels among the Nordic countries. Not: Den nationella valutan är konverterad till euro i köpkraftsstandard, vilket eliminerar effekten av skillnader i prisnivå i de nordiska länderna. 


\section{Housing and construction Boståder och byggande}

The share of one- and two-family houses out of the entire building stock is the highest in Denmark, Åland and Norway with close to 60 per cent in Denmark and Norway and almost 70 per cent in Åland and the lowest in Sweden with approximately 45 per cent. Private ownership of such dwellings, whether a house or an apartment, is common.
Andelen en- och tvåfamiljshus i det totala bostadsbeståndet är högst i Danmark, på Åland och i Norge med nära 60 procent $i$ Danmark och Norge och nästan 70 procent på Åland och lägst i Sverige med ca 45 procent. Sådana bostäder är ofta privatägda, oavsett om det gäller hus eller lägenheter.
Number of dwellings. 2013 Antal bostäder

\begin{tabular}{lr} 
& Denm \\
\hline Number & \\
\hline Total & $\mathbf{2 6 1 2}$ \\
One- and two-family houses & 1539 \\
Apartment blocks & 1002 \\
Other dwellings & 69 \\
Per cent & \\
Total & $\mathbf{1 0 0 . 0}$ \\
One- and two-family houses & 58.9 \\
Apartment blocks & 38.4 \\
Other dwellings &
\end{tabular}

Other dwellings

믄 Hous01

Source: National statistical institutes.

Note: Fimland. Finland includes Aland. Åland and Iceland: 2012 data. Greenland: 2010 data. Norway: Includes vacant dwellings.

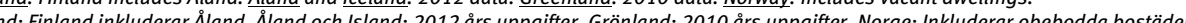

Table 6.1

\begin{tabular}{|c|c|c|c|c|c|c|c|}
\hline Imark & Greenland & Finland & Åland & Iceland & Norway & Sweden & \\
\hline & & & & & & & Antal \\
\hline 2049 & 23112 & 2905731 & 15400 & 131249 & 2449210 & 4633678 & Totalt \\
\hline 39664 & 12642 & 1560336 & 10697 & .. & 1502743 & 1999964 & En- och tvåfamiljshus \\
\hline 02953 & 10334 & 1290215 & 4280 & .. & 831726 & 2332253 & Flerbostadshus \\
\hline 69432 & 136 & 55180 & 423 & .. & 114741 & 301461 & Övriga bostäder \\
\hline & & & & & & & Procent \\
\hline 100.0 & 100.0 & 100.0 & 100.0 & 100.0 & 100.0 & 100.0 & Totalt \\
\hline 58.9 & 54.7 & 53.7 & 69.5 & .. & 61.4 & 43.2 & En- och tvåfamiljshus \\
\hline 38.4 & 44.7 & 44.4 & 27.8 & .. & 34.0 & 50.3 & Flerbostadshus \\
\hline 2.7 & 0.6 & 1.9 & 2.7 & .. & 4.7 & 6.5 & Övriga bostäder \\
\hline
\end{tabular}

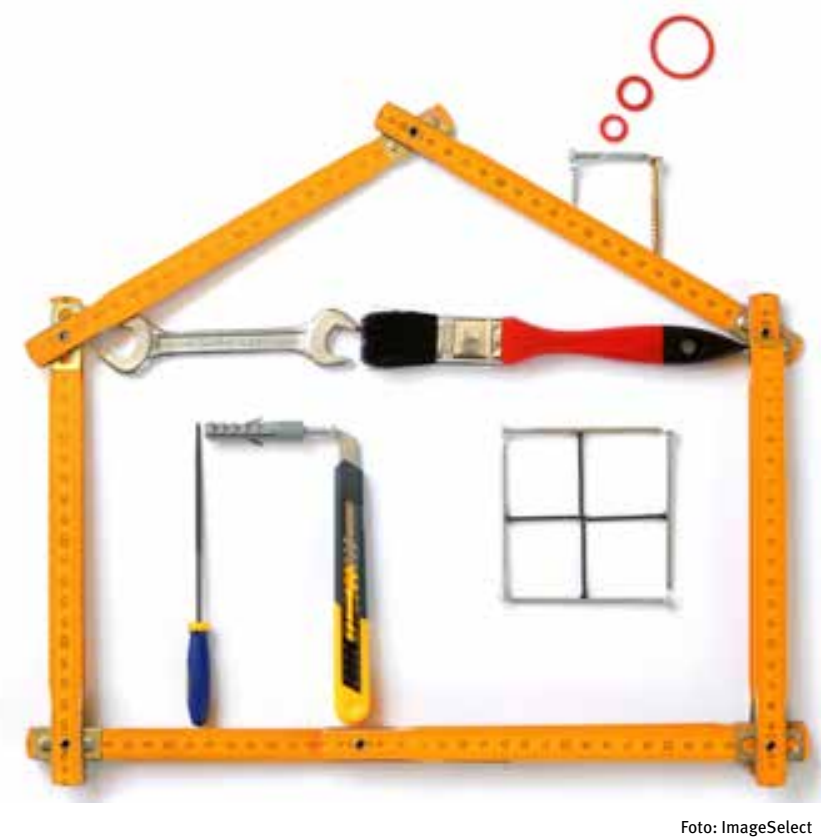




\section{Real estate prices}

The evolution of the financial crisis originating from the subprime crisis which emerged in the USA in 2007 resulted in difficult economic and financial conditions with real estate prices falling in most European countries. In 2013, real estate prices increased in all the Nordic countries.

In all Nordic countries the real estate prices have increased by between 55 to almost 160 per cent from 2000 to 2013. Denmark, the Faroe Islands and Finland had the lowest increase and Iceland the highest. By European standards, such increases are, however, relatively important.

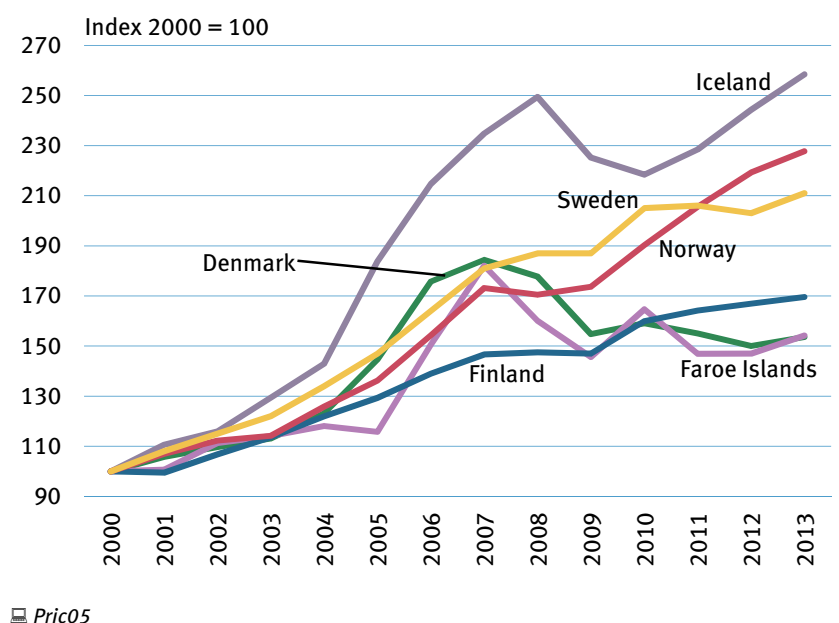

Source: National statistical institutes.

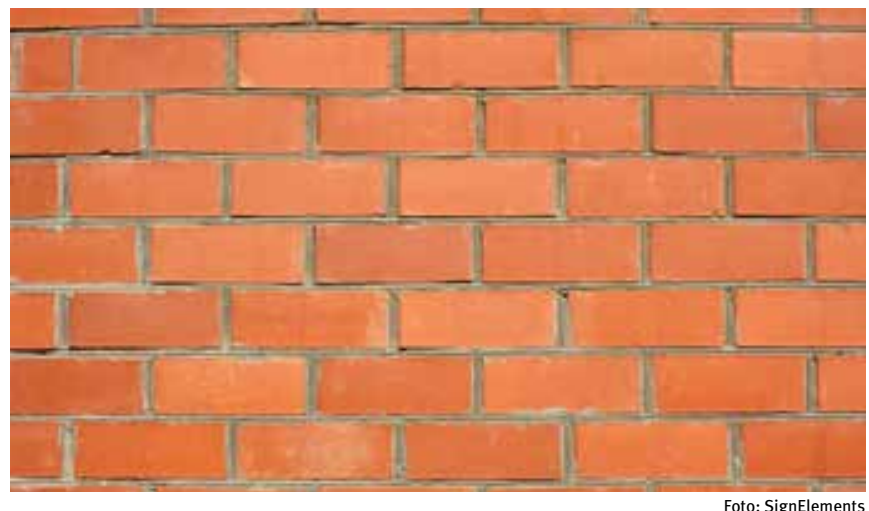

Fastighetspriser

Utvecklingen av den finansiella krisen, med ursprung i den subprimelånekris som uppstod i USA under 2007, har lett till svåra ekonomiska och finansiella villkor med fallande fastighetspriser i de flesta europeiska länder. Under 2013 ökade fastighetspriserna i alla nordiska länder.

I alla nordiska länder har fastighetspriserna stigit med mellan 55 och nästan 160 procent från år 2000 till 2013. Danmark, Färöarna och Finland hade den lägsta ökningen och Island den högsta. Med europeisk standard är en sådan ökning dock relativt stor. 


\section{Construction}

The construction of dwellings has also been heavily influenced by the financial crisis from 2007 and onwards. The index for both Denmark, Finland and Norway plunged to an almost all time low since 1990. Right before the crisis began, the construction in both Norway and Denmark reached an overall high since 1990. The decline in Denmark and Norway thus seems more drastic than in the case of Sweden and Finland.

In all countries, except in Åland, the number of completed dwellings has been increasing since 2010.

\section{Byggande}

Byggandet av bostäder har också varit starkt påverkat av den finansiella krisen från 2007 och framåt. Indexet för både Danmark, Finland och Norge föll till den lägsta nivån sedan 1990. Precis innan krisen började nådde byggandet $i$ både Norge och Danmark den högsta nivån sedan år 1990. Nedgången i Danmark och Norge verkar därför mer drastisk än i Sverige och Finland.

I alla länder har antalet färdigställda bostäder ökat sedan år 2010, utom på Åland.

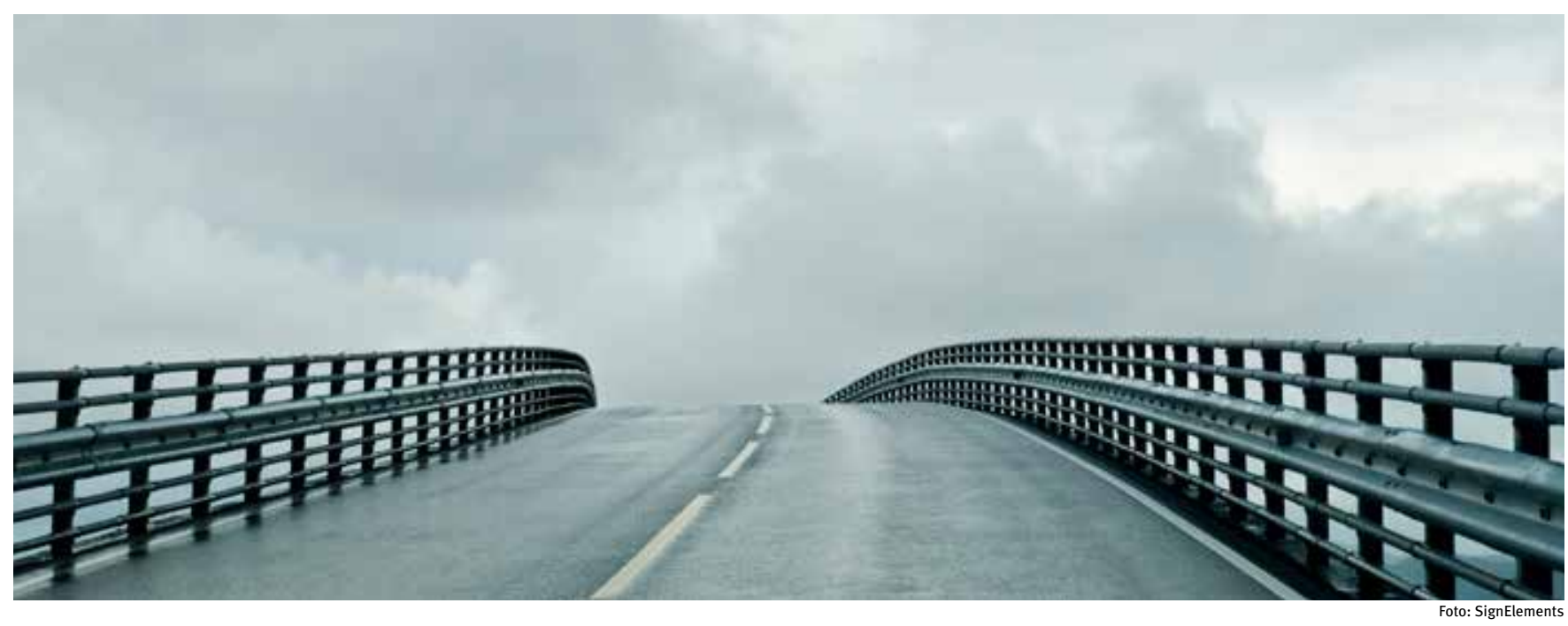




\section{Education \\ Utbildning}

The Nordic countries have in general the same view on both teaching and education. Equal access to - life long - learning, training in the principles of democracy, independence and critical awareness are some of the central issues. The Nordic countries more or less also share the same view regarding the major role the state plays when it comes to education.

Comprehensive schools are compulsory in all Nordic countries and local authorities finance them with general grants from the state. In Denmark and Finland, education does not necessarily have to take place in a school. It may, for example, take place at home.

After 9-10 years of compulsory schooling practically all students continue to study.

De nordiska länderna har i stora drag samma syn på både undervisning och utbildning. Jämlik tillgång till - livslångt lärande, utbildning i principerna för demokrati, självständighet och kritisk medvetenhet är några av de centrala frågorna. De nordiska länderna har också mer eller mindre samma syn på den viktiga roll staten spelar när det gäller utbildning.

Grundskolan är obligatorisk i samtliga nordiska länder och lokala myndigheter finansierar den med allmänna bidrag från staten. I Danmark och Finland måste utbildning inte nödvändigtvis äga rum i en skola. Den kan till exempel ske i hemmet.

Efter 9-10 år i grundskolan fortsätter praktiskt taget alla elever att studera.

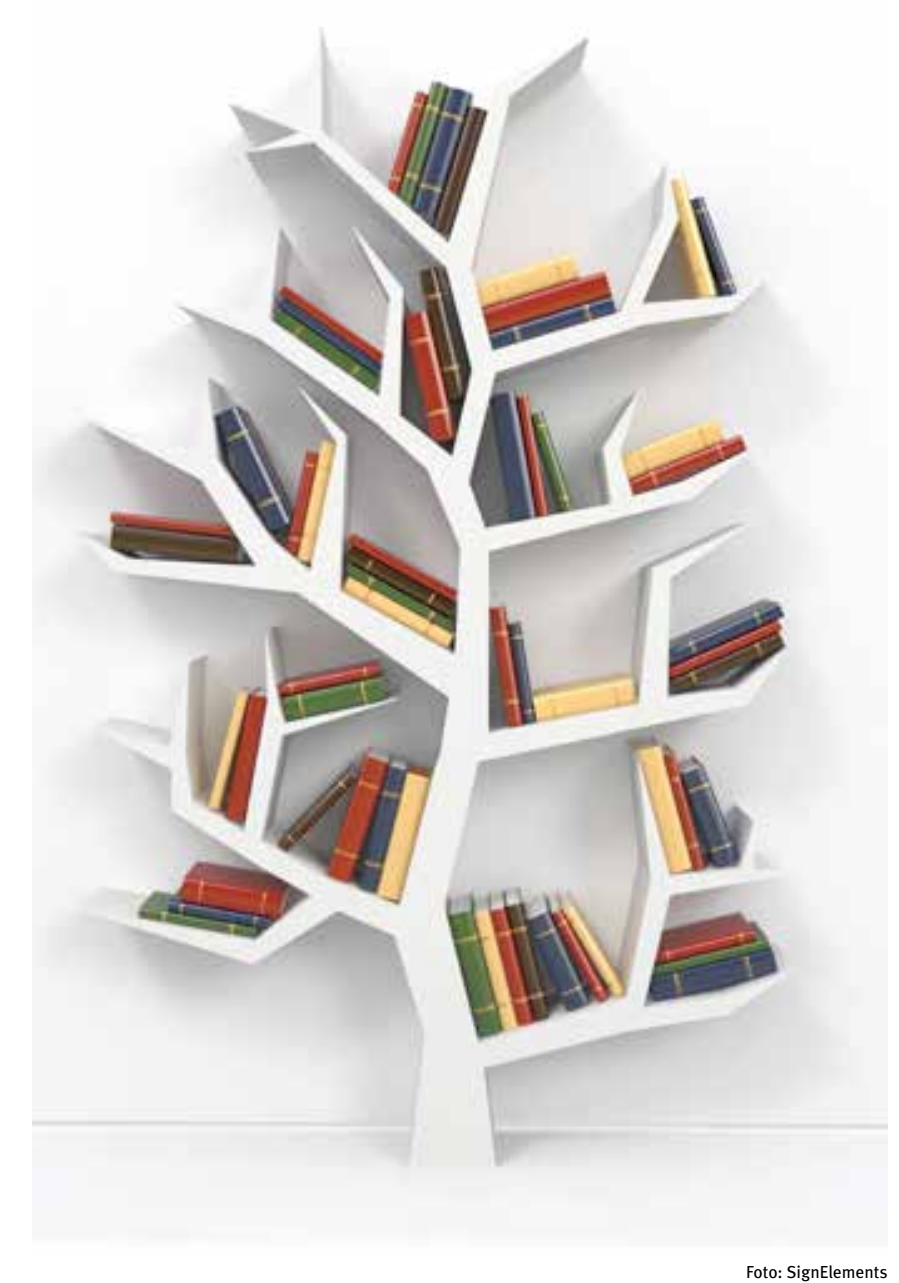




\section{Expenses for education}

Differences between the Nordic countries are small as far as the total number of resources invested in education are concerned, apart from Greenland that spends almost 14 per cent of their GDP on education. General government expenditure on education accounts for between 5.5-8.8 per cent of GDP for the rest of the Nordic countries. Government expenditure as a share of GDP gives an overall view of the allocated resources to the sector but does not say anything about how effectively the resources are being used.

However, the proportion of costs allocated to private schools show clear differences. In Denmark, where private schools have a long tradition, a higher proportion of costs to the comprehensive schools are going to private schools.
Figure 7.1 Offentliga utgifter för utbildning

\section{Offentliga utgifter för utbildning}

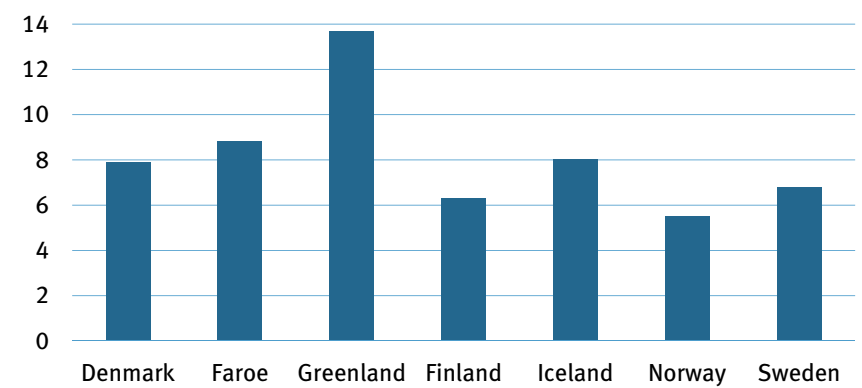

Denmark Faroe Greenland Finland Iceland Norway Sweden Island
16 Per cent of GDP

Skillnaderna mellan de nordiska länderna är små när man pratar om den totala mängd av resurser som investeras $i$ utbildning, bortsett från Grönland som spenderar nästan 14 procent av sin BNP på utbildning. Offentliga utgifter för utbildning står för mellan 5,5-8,8 procent av BNP för de andra de nordiska länderna. De offentliga utgifterna som andel av BNP ger en helhetsbild av de tilldelade resurserna till sektorn, men säger inget om hur effektivt resurserna används.

Men den andel av kostnaderna som ges till friskolor eller privatskolor visar tydliga skillnader. I Danmark, där privata skolor har en lång tradition, går en högre andel av kostnaderna för grundskolan till privata skolor.
믄 Pubs13

Source: Eurostat.

Note: Finland: Includes Åland. Faroe Islands: 2011 figures.

Not: Finland: Inkluderar Âland. Färöarna: 2011 års uppgifter. 


\section{Enrolled students}

The total number of students aged 15-39 enrolled at upper secondary or tertiary level education (ISCED levels 3-6) in the Nordic countries is approximately 2.5 million and represents 31 per cent of the age group between 15-39. Students aged 15-39 cover the majority of the enrolment.

Women constitute the majority of students at upper secondary and tertiary levels in all age groups.
Inskrivna studenter

Det totala antalet inskrivna elever/studenter i åldern 15-39 år på gymnasie-, universitets- och högskolenivå (ISCED-nivå 3-6) i de nordiska länderna är 2,5 miljoner och utgör 31 procent av åldersgruppen 15-39 år. Elever/studenter i åldern 15-39 år representerar majoriteten av de inskrivna.

Kvinnor utgör den största andelen av de inskrivna studenterna på gymnasie-, universitets- och högskolenivå i alla åldersgrupper.
Students enrolled aged 15-39. 2013/2014 Inskrivna elever/studenter i åldern 15-39 år

$\begin{array}{rr}\text { Total } & \text { Primary level } \\ \text { Totalt } & \text { Grundskola } \\ \text { (ISCED 1-6) } & \text { (ISCED 1-2) }\end{array}$

Secondary level
Gymnasium
och yrkesutbildning
(ISCED 3-4)
Tertiary level
Universitet Universitet
och högskola och hogskola
(ISCED 5-6)

Per cent of total population

aged 15-39 years

Denmark

Greenland

Finland

Åland

Iceland

Norway

Sweden

믈 $\operatorname{duc02}$

Source: National statistical institutes

2012/2013 data. Finland includes Åland. Sweden: 2011/2012 data.

Wt: Grönland, Finland och Island: 2012/2013 års uppgifter. Finland inkluderar Åland. Sverige: 2011/2012 års uppgifter.
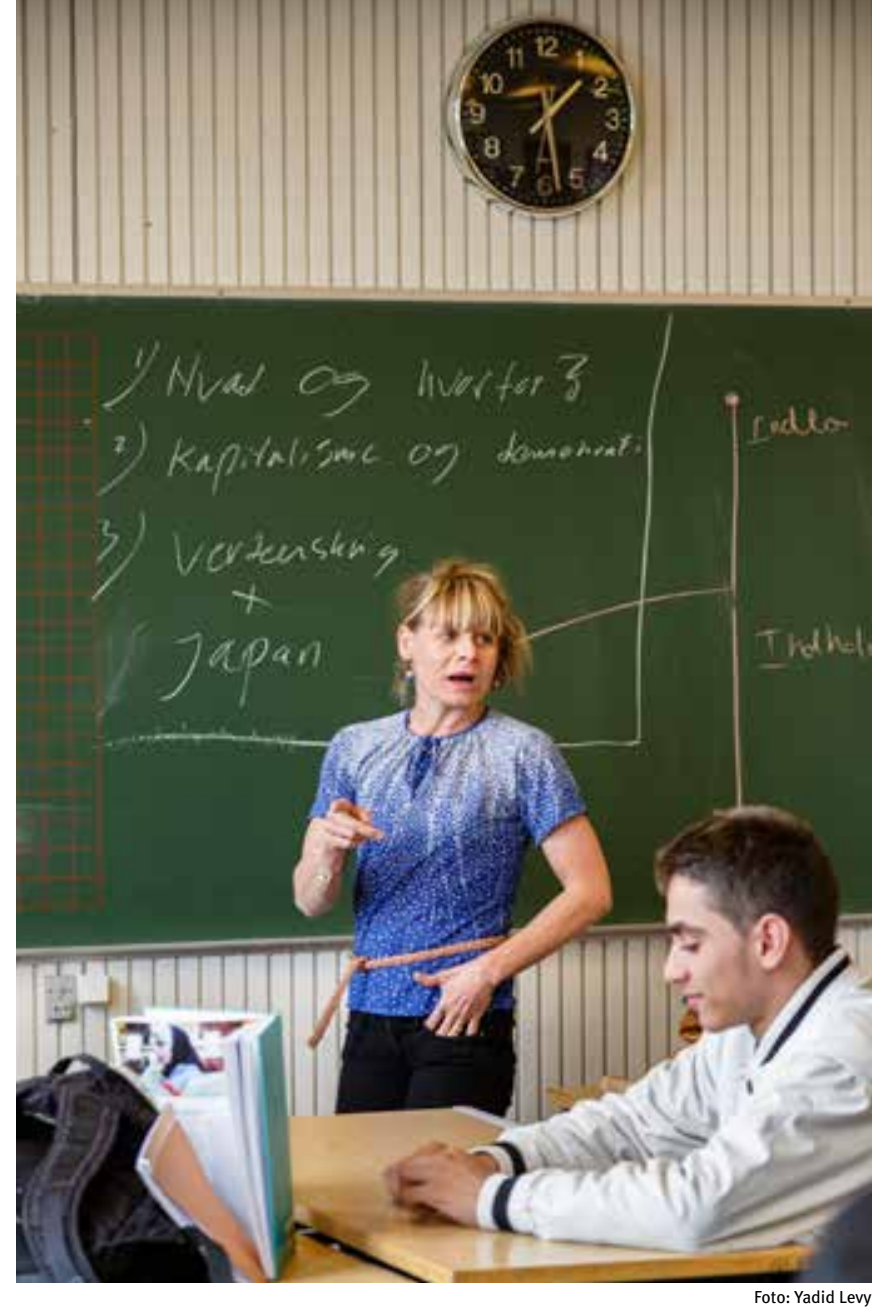

72 Education - Utbildning

Table 7.1

\begin{tabular}{rrrrr} 
& & & $\begin{array}{r}\text { Procent av total befolkning } \\
\text { ialdern 15-39 år }\end{array}$ \\
35.9 & & & Danmark \\
36.5 & 7.1 & 15.7 & 13.1 & Grönland \\
39.8 & - & 27.1 & 9.3 & Finland \\
24.9 & 4.0 & 19.5 & 16.2 & Aland \\
39.4 & 4.7 & 14.4 & 14.8 & Island \\
32.4 & 3.8 & 21.6 & 12.9 & Norge \\
37.3 & 3.8 & 15.7 & 13.2 & Sverige \\
\hline
\end{tabular}




\section{University level students}

Finland is the Nordic country that has relatively most university level students. Among the 20-39-year-olds, close to 19 per cent of the Finns are enrolled at higher education today, while the same is the case for 17 per cent in Iceland and 16 in Denmark and

Sweden. In Norway the enrolment figure for students at university level is close to 15 per cent among the 20-39-year-olds.
Studerande på universitetsnivå

Finland är det land i Norden som har förhållandevis flest

studerande på universitetsnivå. Bland de 20-39-åriga studerar nära 19 procent i Finland i dag på denna nivå, medan samma sak gäller för 17 procent på Island och 16 procent i Danmark och Sverige. I Norge studerar nära 15 procent av alla i åldern 20-39 år på universitetsnivå.
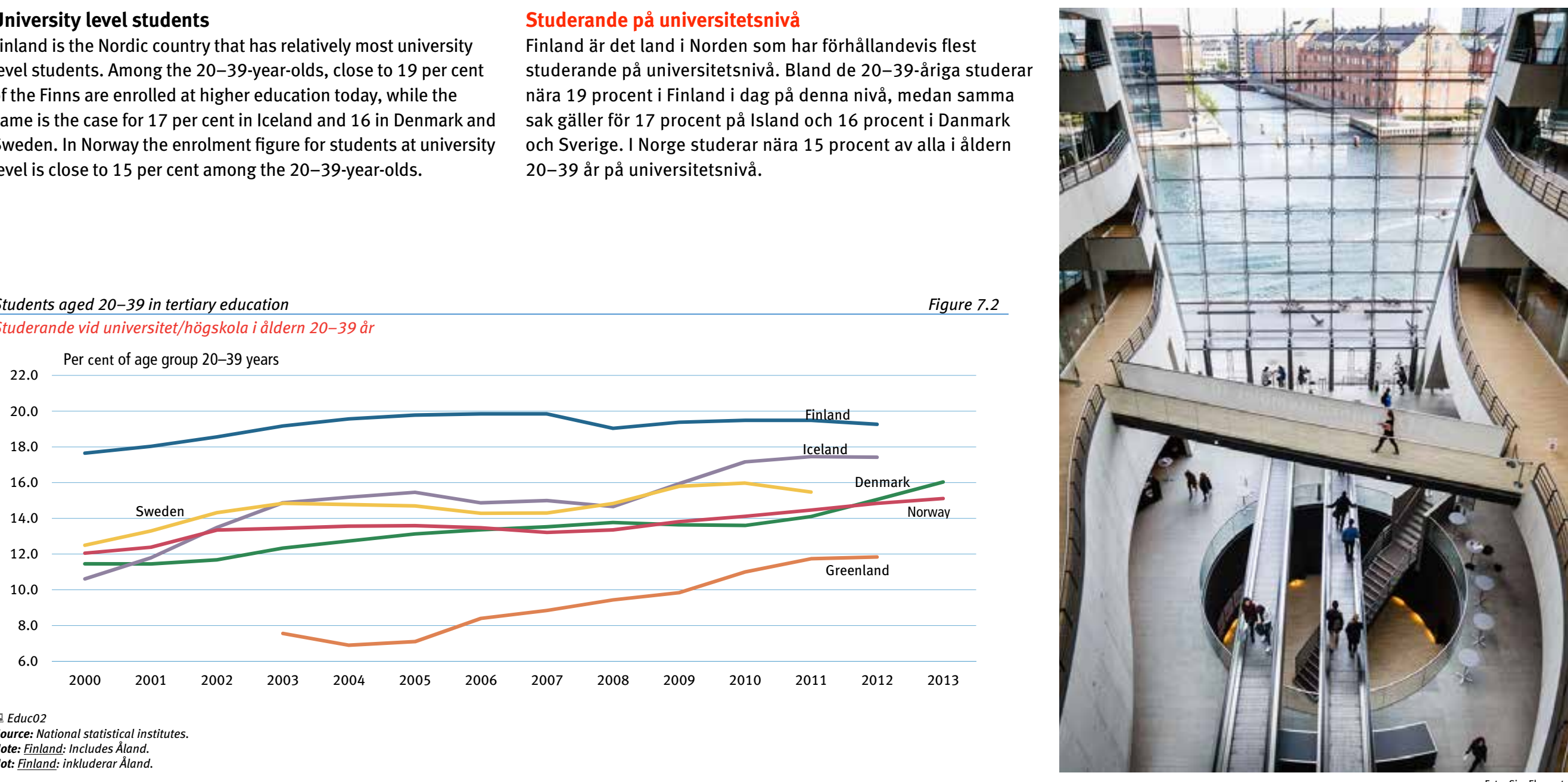


\section{Graduates}

In all the Nordic countries, the majority of graduates at tertiary level are women. Men constitute less than 40 per cent of those graduating. Female graduates dominate within fields such as health and social services, whereas men dominate in fields such as engineering, manufacturing and construction.

\section{Enrolled}

Among university level students, there are far more individuals in Finland who study natural sciences, information technology or engineering than in the other Nordic countries.
In most of the countries the highest proportion of enrolled students are found within in the fields of social science, business and law.

Examinerade

I alla de nordiska länderna är kvinnorna i majoritet av de som tar examen på universitets- och högskolenivå. Männen utgör mindre än 40 procent av de examinerade. Kvinnorna dominerar inom t.ex. hälsa och socialvård, medan männen är i majoritet när det gäller t.ex. ingenjörsrelaterade ämnen.
Inskrivna studenter

Bland de inskrivna på universitets- och högskolenivå har Finland långt fler som läser naturvetenskap, IT eller ingenjörsrelaterade ämnen än de övriga nordiska länderna.

I de flesta länder finns den högsta andelen inskrivna elever inom områdena samhällsvetenskap, ekonomi och juridik.

Graduates at tertiary level, aged 15-74 by field of education. 2013

Table 7.2

Examinerade på universitets- och högskolenivå i åldern 15-74 år efter utbildningsinriktning

\begin{tabular}{|c|c|c|c|c|c|c|c|c|}
\hline & Denmark & Greenland & Finland & Åland & Iceland & Norway & Sweden & \\
\hline Number of graduated students & & & & & & & & Antal examinerade studenter \\
\hline Total & 53706 & 164 & 53296 & 71 & 4098 & 42120 & 69127 & Totalt \\
\hline Men, per cent & 42.6 & 31.7 & 39.0 & 52.1 & 35.6 & 39.0 & 37.1 & Män, procent \\
\hline Women, per cent & 57.4 & 68.3 & 61.0 & 47.9 & 64.4 & 61.0 & 62.9 & Kvinnor, procent \\
\hline Per cent & & & & & & & & Procent \\
\hline Total & 100.0 & 100.0 & 100.0 & 100.0 & 100.0 & 100.0 & 100.0 & Totalt \\
\hline General programmes & - & & - & - & - & 0.4 & - & Allmänna program \\
\hline Teacher training, education science & 6.1 & 20.7 & 6.9 & - & 14.0 & 17.7 & 11.4 & Lärarutbildning, pedagogik \\
\hline Arts, humanities and religion & 13.7 & 9.1 & 13.3 & - & 12.8 & 8.6 & 6.1 & Estetiska och humanistiska program samt religion \\
\hline Social science, business and law & 32.2 & 33.5 & 25.3 & 15.5 & 37.5 & 26.9 & 28.3 & Samhällsvetenskap, ekonomi och juridik \\
\hline Natural science, mathematics and computing & 8.7 & 6.1 & 7.5 & - & 8.0 & 7.8 & 7.8 & Naturvetenskap, matematik och datavetenskap \\
\hline Engineering, manufacturing and construction & 14.3 & 6.1 & 20.1 & 26.8 & 10.0 & 9.4 & 17.8 & Maskinteknik, tillverkning och byggteknik \\
\hline Agriculture, forestry and fishery & 1.5 & & 1.9 & - & 0.8 & 0.8 & 1.1 & Jordbruk, skogsbruk och fiske \\
\hline Health and social services & 20.9 & 21.3 & 19.7 & 25.4 & 14.4 & 22.7 & 24.5 & Hälsa och socialvård \\
\hline Services and defence & 2.6 & 3.0 & 5.4 & 32.4 & 2.5 & 5.9 & 3.1 & Serviceyrken och försvar \\
\hline Not specified & & & & & - & - & & Ospecificerat \\
\hline
\end{tabular}

믈 Educ03

Source: National statistical institutes.

ats 2011 data.

Not: Finland och Island: 2012 ärs uppgifter. Finland inkluderar Äland. Sverige: 2011 års uppgifter.

74 Education - Utbildning 


\section{Level of education}

When comparing the Nordic countries with respect to level of education one must take into account the different educational systems. Some types of education are difficult to classify, e.g. at either lower or upper secondary level, and practices may differ among the Nordic countries. This might also account for some of the differences in the share of population attaining a certain level of education.

The majority of the Nordic population in the age group 25-74 years, who have achieved an education are still men, but it is the women who have the highest level of education. In 2013,

60 per cent of the people who graduated from higher education on the tertiary level were women.

\section{Utbildningsnivåer}

När man jämför utbildningsnivåer i de nordiska länderna måste man ta hänsyn till att länderna har olika utbildningssystem. Vissa typer av utbildningar är svåra att klassificera och praxis kan variera mellan de nordiska länderna. Detta kan också vara orsaken till en del av skillnaderna i fråga om hur stor del av befolkningen som uppnår en viss utbildningsnivå.

Majoriteten av den nordiska befolkningen i åldersgruppen 25-74 år som har uppnått en utbildning är fortfarande män, men det är kvinnorna som har den högsta utbildningsnivån. År 2013 var 60 procent av alla som tog examen på högskolenivå kvinnor.

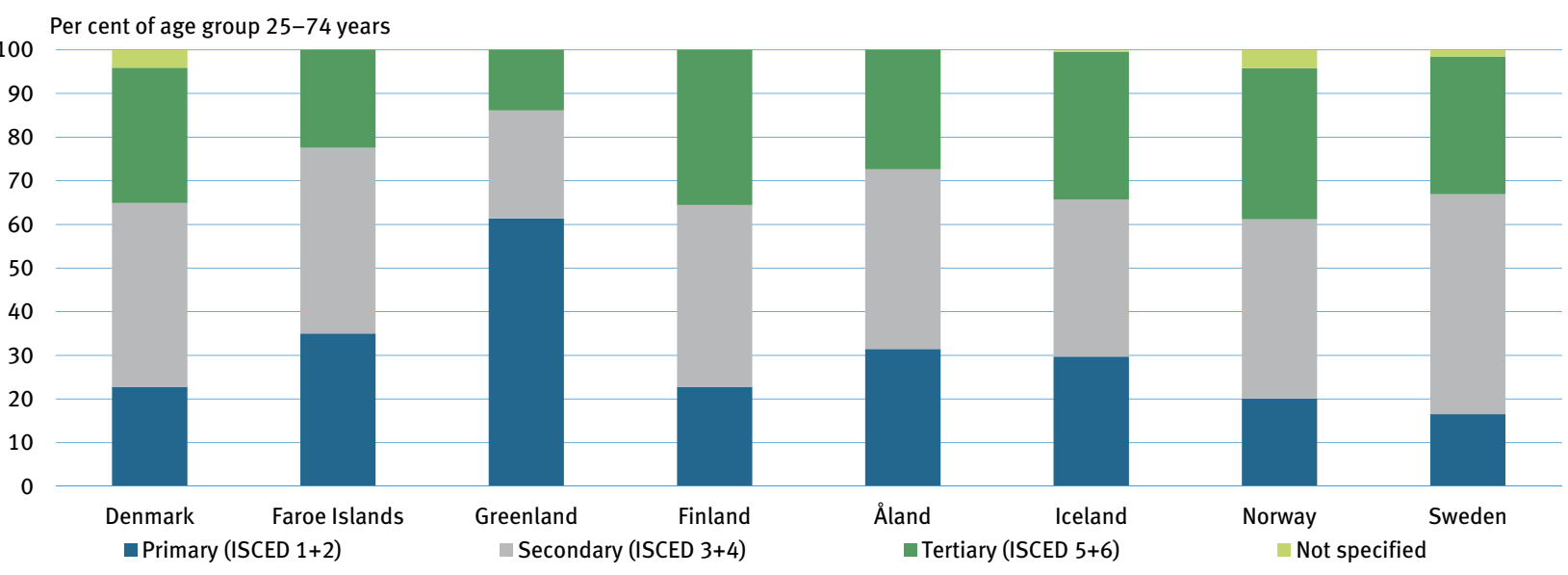

믈 Educo1

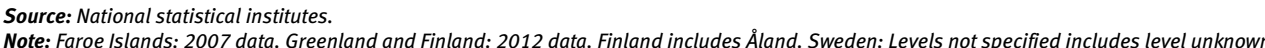

Not: Färäarna: 2007 års uppgifter. Gränland och Finland: 2012 års uppgifter. Finland inkluderar Åland. Sverige: Ospecificerad nivå inkluderar okënd nivo̊.
Did you know that ... in the early 60 s the men dominated almost all university studies. In 2013, it is just the opposite -6 out of 10 of all students in universities are women. In the 60 s only every third student was a woman.

Visste du att ... i början av 60-talet dominerade män nästan alla universitetsstudier. Under 2013 är det precis tvärtom -6 av 10 av alla studenter på universiteten är kvinnor. På 60-talet var endast var tredje student kvinna. 


$\begin{array}{rrrrr}\text { Total } & \text { Primary level } & \text { Secondary level } & \text { Tertiary level } & \text { Level not specified } \\ \text { Totalt } & \text { Grundskola } & \text { Gymnasium } & \text { Universitet } & \text { or unknown } \\ \text { (ISCED 1-6) } & \text { (ISCED 1-2) } & \text { och yrkesutbildning } & \text { och högskola } & \text { Ospecificerad } \\ & & \text { (ISCED 3-4) } & \text { (ISCED 5-6) } & \text { eller okänd }\end{array}$

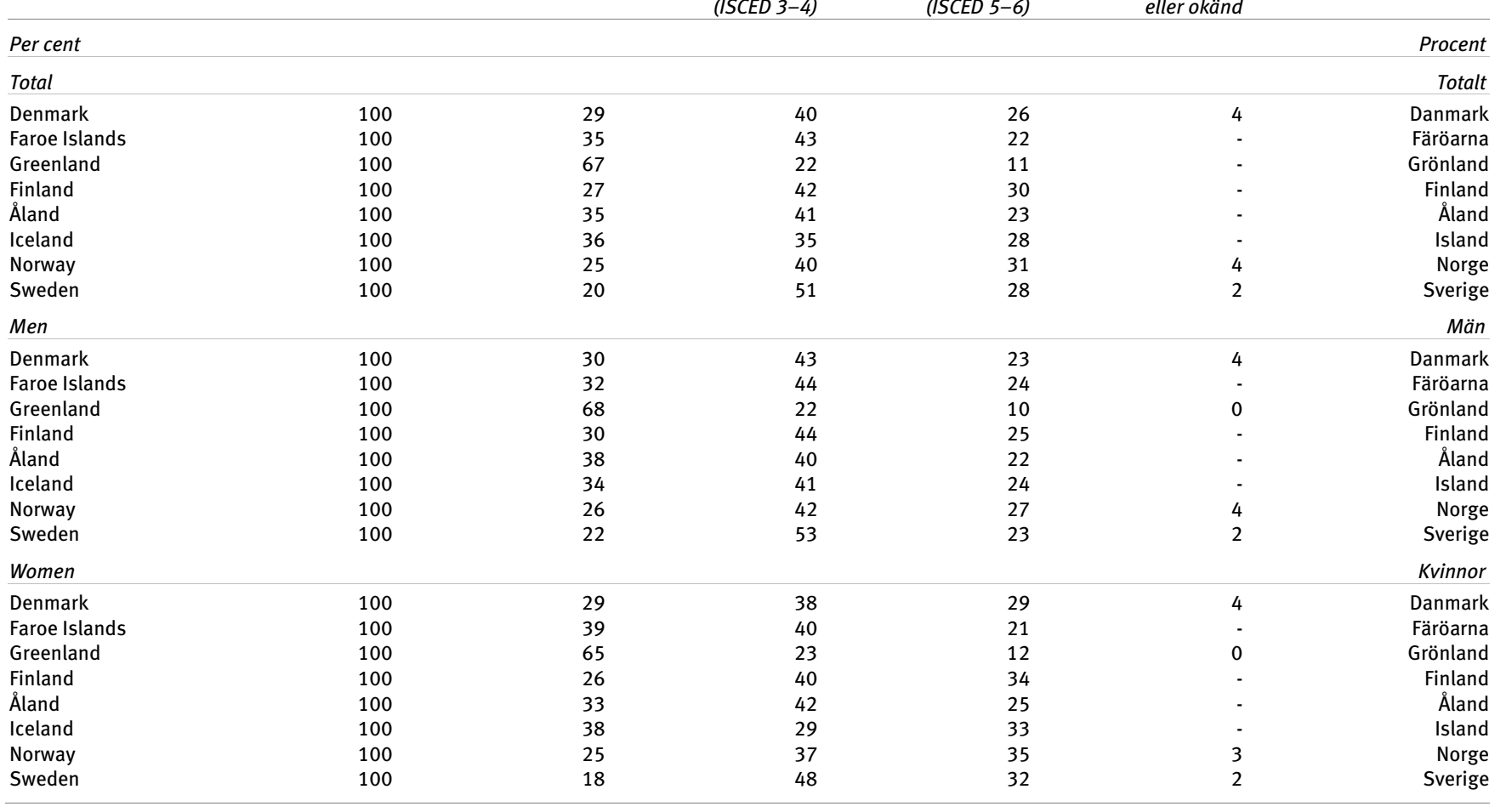

Source: National statistical institutes.

2072007 data. Greenland and Finland: 2012 data. Finland includes Åland.

Not: Färöarna: 2007 års uppgifter. Grönland och Finland: 2012 års uppgifter. Finland inkluderar Åland.

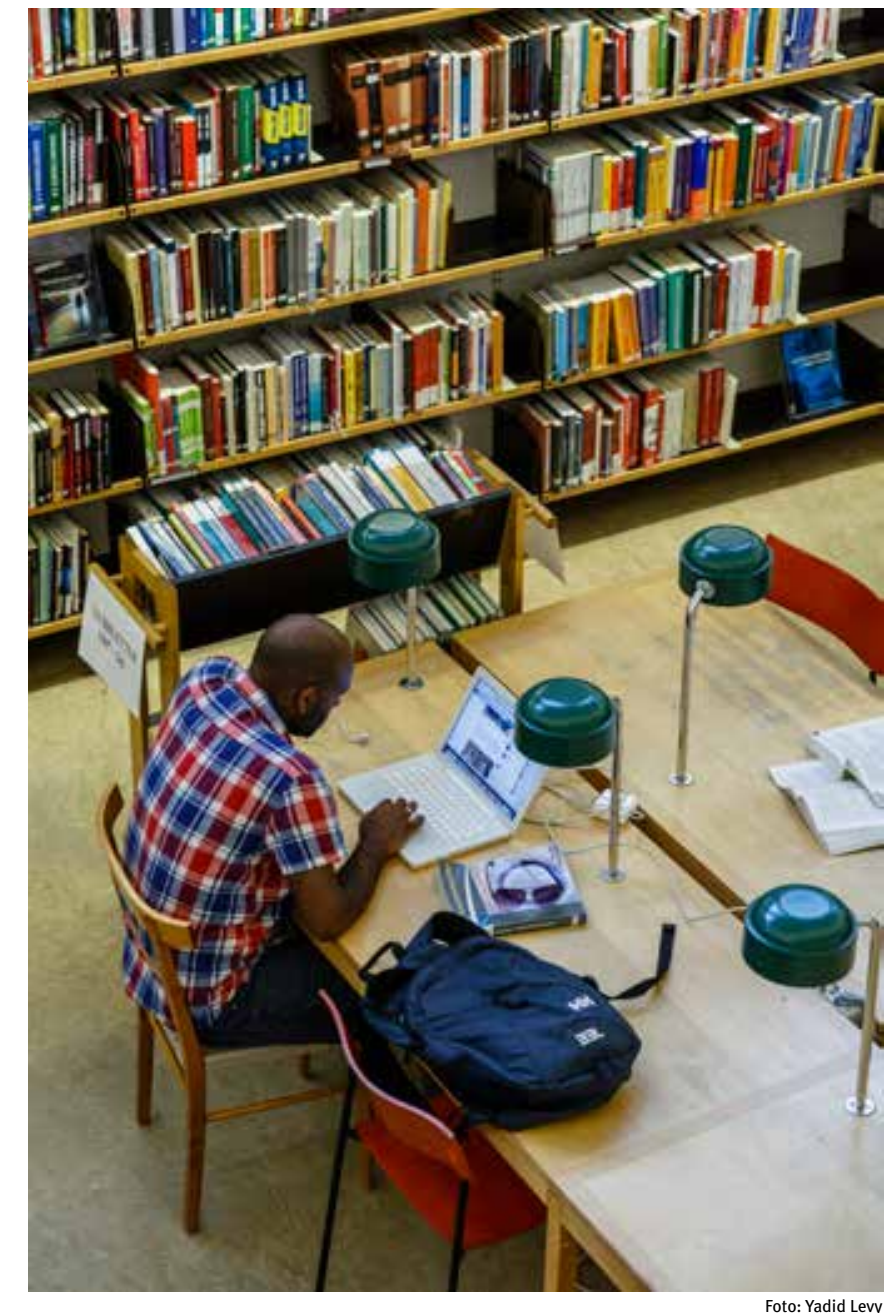

76 Education - Utbildning 
Denmark Faroe Islands Greenland

Finland

Åland

Iceland

Norway

Sweden

Number of persons

Total

Men, per cent

Women, per cent

Percent

Total

General programmes

Teacher training, education science

Arts, humanities and religion

Social science, business and law

Natural science, mathematics and computing

Engineering, manufacturing and construction

Agriculture, forestry and fishery

Health and social services

Services and defence

1107466

$\begin{array}{rr}466 & 7750 \\ 44.1 & 56.8\end{array}$

55.9

7750
56.8
43.2

4772
49.4

1235789

789
42.6

64000

64000
42.8

$1153244 \quad 1938742$

$\begin{array}{rr}44.5 & 42.3 \\ 55.5 & 57.7\end{array}$

42.3
57.7

Antal personer

50.6

00.0

100.0

100.0

100.0

22.7
4.9

12.1

10.1
21.6
4.7

$18.8-21.7$

$\begin{array}{rr}9.4 & 6.2 \\ - & 0.8\end{array}$

$\begin{array}{rr}9.4 & 0.8 \\ 18.7 & 18.3 \\ 20.0 & 10.6\end{array}$

Not specified

Educ01

Source: National statistical institutes.

. 2007 data. Finland: 2011 data. Finland includes Åland. Sweden: Fields not specified includes fields unknown. Age group 16-74 years.

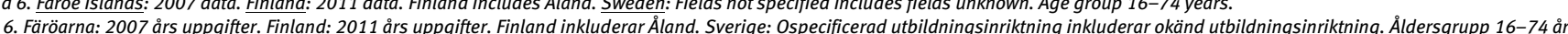

Did you know that ... the number of students at universities in the Nordic countries has risen considerably from 1960 to today - from around 90000 students in 1960 to now almost 1.3 million students.
Visste du att ... antalet studerande på universitet och högskolor i de nordiska länderna har ökat betydligt från 1960 till i dag - från omkring 90000 år 1960 till nästan 1,3 miljoner i dag. 
Programme for International Student Assessment (PISA)

Every three years OECD assesses how far students near the end of compulsory education have acquired some of the knowledge and skills essential for full participation in society. PISA assesses the levels of knowledge and skills attained by 15 -year-olds in the OECD (and other partner-) countries within three areas: reading, mathematics and science.

Iceland and Sweden have a lower score than the OECD average in reading literacy. In mathematical literacy both Iceland and Norway as well as Sweden are under the average. Besides Finland, all the other Nordic countries score lower than the OECD average in scientific literacy. Finland has the highest scores of all the Nordic countries on all skills - well above the OECD average.

Programme for International Student Assessment (PISA) Vart tredje år mäter OECD i vilken grad elever som närmar sig slutet av den obligatoriska skolan har lärt sig de färdigheter de behöver för att kunna fungera i samhället. PISA mäter kunskapsnivån hos 15-åringar i OECD-länderna (och andra förbundsländer) inom tre ämnen: läsförståelse, matematik och naturvetenskap.

Island och Sverige placerar sig under OECD-genomsnittet i läsning. I matematik ligger såväl Island och Norge som Sverige under. Förutom Finland ligger alla de övriga nordiska länderna lägre än OECD-genomsnittet inom ämnet vetenskap. Finland har det allra bästa resultatet av alla nordiska länder inom alla ämnesområden - betydligt över genomsnittet i OECD.

\begin{tabular}{|c|c|c|c|c|c|}
\hline Reading literacy & & Mathematical literacy & & Scientific literacy & \\
\hline & Score & & Score & & Score \\
\hline Japan & 538 & Korea, Republic of & 554 & Japan & 547 \\
\hline Korea, Republic of & 536 & Japan & 536 & Finland & 545 \\
\hline Finland & 524 & Switzerland & 531 & Estonia & 541 \\
\hline Canada & 523 & Netherlands & 523 & Korea, Republic of & 538 \\
\hline Ireland & 523 & Estonia & 521 & Poland & 526 \\
\hline Poland & 518 & Finland & 519 & Canada & 525 \\
\hline Estonia & 516 & Canada & 518 & Germany & 524 \\
\hline New Zealand & 512 & Poland & 518 & Netherlands & 522 \\
\hline Australia & 512 & Belgium & 515 & Ireland & 522 \\
\hline Netherlands & 511 & Germany & 514 & Australia & 521 \\
\hline Belgium & 509 & Austria & 506 & New Zealand & 516 \\
\hline Switzerland & 509 & Australia & 504 & Switzerland & 515 \\
\hline Germany & 508 & Slovenia & 501 & United Kingdom & 514 \\
\hline France & 505 & Ireland & 501 & Slovenia & 514 \\
\hline Norway & 504 & New Zealand & 500 & Czech Republic & 508 \\
\hline United Kingdom & 499 & Denmark & 500 & Austria & 506 \\
\hline United States & 498 & Czech Republic & 499 & Belgium & 505 \\
\hline Denmark & 496 & France & 495 & OECD average & 501 \\
\hline $\mathrm{OECD}$ average & 496 & OECD average & 494 & France & 499 \\
\hline Czech Republic & 493 & United Kingdom & 494 & Denmark & 498 \\
\hline Italy & 490 & Iceland & 493 & United States & 497 \\
\hline Austria & 490 & Luxembourg & 490 & Spain & 496 \\
\hline Hungary & 488 & Norway & 489 & Norway & 495 \\
\hline Portugal & 488 & Portugal & 487 & Hungary & 494 \\
\hline Spain & 488 & Italy & 485 & Italy & 494 \\
\hline Luxembourg & 488 & Spain & 484 & Luxembourg & 491 \\
\hline Israel & 486 & Slovak Republic & 482 & Portugal & 489 \\
\hline Iceland & 483 & United States & 481 & Sweden & 485 \\
\hline Sweden & 483 & & 478 & Iceland & 478 \\
\hline Slovenia & 481 & Hungary & 477 & Slovak Republic & 471 \\
\hline Greece & 477 & Israel & 466 & Israel & 470 \\
\hline Turkey & 475 & Greece & 453 & Greece & 467 \\
\hline Slovak Republic & 463 & Turkey & 448 & Turkey & 463 \\
\hline Chile & 441 & Chile & 423 & Chile & 445 \\
\hline Mexico & 424 & Mexico & 413 & Mexico & 415 \\
\hline
\end{tabular}

Sowice:

믈 Pisa01 


\section{Student financial aid}

In all the Nordic countries students have the opportunity to receive financial aid during their studies. The financial aid consists of grants and student loans.

Students in Denmark and in Finland receive the most financial aid in the form of grants. More than 60 per cent of the total support to students is given as a grant. Students in Iceland only receive financial aid in the form of a student loan, but are able to borrow more money than in any other Nordic country. In Norway and Sweden, the grant covers between 30 and 40 per cent of the total financial aid.

In Denmark and in the Faroe Islands, the student financial aid is typically granted for 11 to 12 months annually, while the other Nordic countries normally grant it for the 9 to 10 months of actual period of study. Grants are taxable income in Denmark and Finland. In Sweden, Norway and Iceland, they are tax-free. Detailed rules have been established on the terms for receiving grants as well as for payment of interest and the repayment of loans.
Studiemedel

I alla nordiska länder har studerande möjlighet att få ekonomiskt studiestöd under sin studietid. Studiestödet består av bidrag och lån.

Studiemedlens bidragsdel är störst i Danmark och Finland. Mer än 60 procent av det totala studiestödet ges som ett bidrag. På Island ges hela studiestödet som lån. Möjligheterna att få stora studielån är å andra sidan störst på Island. I Norge och Sverige utgör bidragsdelen mellan 30 och 40 procent av hela studiestödet.

I Danmark och på Färöarna får en studerande vanligtvis studiemedel under elva till tolv månader per år, medan man i de övriga nordiska länderna begränsar sig till de nio till tio månader av året då studierna bedrivs. I Danmark och Finland betraktas studiebidraget som skattepliktig inkomst, medan det i Sverige, Norge och på Island är skattefritt. Naturligtvis finns det detaljerade regler för de villkor som gäller för att få studiebidrag samt för betalning av ränta och återbetalning av studielånen.
1400 Euro per month

1200

1200

1000

800

600

400

200

Denmark

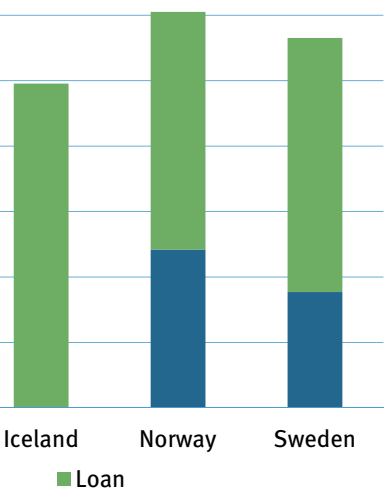

Grant
- Loan

믈 Educo7

Source: KELA Center for Student Financial Aid, Helsinki, and national statistical institutes. 


\section{Studying abroad}

More than 51000 full-time students from the Nordic countries were enrolled for studies in another country than their own during the study year 2012/2013. Generally, the Nordic students tend to study in English-speaking countries. The preferred country of study is Great Britain, where almost one fourth of all Nordic students abroad are found. 14 per cent of the Nordic students abroad are enrolled for studies in the United States or Canada, while 4.5 per cent choose Australia or New Zealand. Around 14 per cent of the Nordic students who are enrolled for full-time studies abroad have chosen another Nordic country, and Denmark is their preferred country. Nordic countries operate in many ways as a common market of education. If you are resident in a Nordic country, you have the right to seek admission to higher education throughout the Nordic region on the same terms as its own applicants.

\section{Studier utomlands}

Studieåret 2012/2013 läste mer än 51000 heltidsstuderande från de nordiska länderna i ett annat land än det egna hemlandet. Nordiska studenter väljer oftast att studera i engelskspråkiga länder. Det mest populära studielandet är Storbritannien, där nästan en fjärdedel av alla nordiska utlandsstuderande vistas. Av de nordiska utlandsstuderande läste 14 procent $i$ USA eller Kanada medan 4,5 procent valde Australien eller Nya Zeeland. Omkring 14 procent av de nordiska studenter som läser på heltid utomlands har valt ett annat nordiskt land, och här är Danmark det vanligaste landet. Norden fungerar på många sätt som en gemensam marknad för utbildning. Om du är bosatt i ett nordiskt land har du rätt att få tillträde till högre utbildning i hela Norden på samma villkor som landets egna sökande.
Nordic students abroad by destination. 2012/2013

Nordiska studerande i utlandet efter studieland

\begin{tabular}{|c|c|c|c|c|c|c|c|}
\hline Persons from & Denmark & Finland & Åland & Iceland & Norway & Sweden & Personer från \\
\hline Total & 3876 & 6256 & 1068 & 2333 & 15746 & 22318 & Totalt \\
\hline $\begin{array}{l}\text { Country of study } \\
\text { Nordic total }\end{array}$ & 814 & 1363 & 1030 & 1090 & 3349 & 2928 & $\begin{array}{c}\text { Studieland } \\
\text { Norden, totalt }\end{array}$ \\
\hline Denmark & & 141 & 6 & 762 & 2634 & 1799 & Danmark \\
\hline Finland & 9 & & 288 & 3 & 18 & 238 & Finland \\
\hline Iceland & 45 & 10 & - & . & 25 & 42 & Island \\
\hline Norway & 235 & 58 & 10 & 73 & & 849 & Norge \\
\hline Sweden & 525 & 1154 & 726 & 252 & 672 & & Sverige \\
\hline France & 68 & 119 & 1 & 29 & 209 & 787 & Frankrike \\
\hline Germany & 242 & 261 & 1 & 75 & 210 & 734 & Tyskland \\
\hline Great Britain & 1523 & 1870 & 11 & 251 & 4702 & 4719 & Storbritannien \\
\hline Italy & 24 & 69 & - & 39 & 77 & 457 & Italien \\
\hline Netherlands & 173 & 283 & 4 & 95 & 353 & 286 & Nederländerna \\
\hline Spain & 75 & 140 & 3 & 55 & 127 & 858 & Spanien \\
\hline USA & 362 & 393 & 5 & 354 & 1707 & 4906 & USA \\
\hline Canada & 33 & 45 & - & 42 & 144 & 156 & Kanada \\
\hline Australia, New Zealand & & & & & & & Australien, Nya Zeeland \\
\hline and other Oceania & 124 & 134 & - & 28 & 1079 & 1213 & och övriga Oceanien \\
\hline Other & 438 & 1579 & 13 & 348 & 3789 & 5274 & Övriga \\
\hline
\end{tabular}

\section{Someros}

SE Educ05 5 Sorce: KELA Center for Student Financial Aid, Helsinki, and national statistical institutes. 


\section{Labour market Arbetsmarknad}

The Nordic labour markets share many common characteristics. Nordic salaries and working conditions are quite consid erably regulated by collective bargaining agreements. Unions and employers are also very much involved in drafting legislation, in particular legislation governing the labour market.

This model has helped develop a Nordic labour market characterised by a high degree of equality, security and consensus. The model has also played a crucial role in the evolution of the Nordic welfare society as we know it today.

The Nordic countries are characterised by high employment and low unemployment. All countries have a well-working labour market. By international standards, a very high proportion of the adult population is economically active - both men and women.
Arbetsmarknaderna i de nordiska länderna har många gemensamma drag. I de nordiska länderna regleras löneoch arbetsvillkor i betydande grad genom avtal mellan arbetsmarknadens parter. Arbetsmarknadens parter involveras i stor utsträckning vid förberedelser av lagstiftning, särskilt på arbetsmarknadsområdet. Denna nordiska arbetsmarknadsmodell har bidragit till utvecklandet av en nordisk arbetsmarknad som är präglad av en hög grad av jämlikhet, säkerhet och konsensus. Modellen har spelat en avgörande roll för utvecklingen av de nordiska välfärdssamhällen vi känner i dag.

De nordiska länderna präglas av hög sysselsättningsgrad och låg arbetslöshet. De har alla välfungerande arbetsmarknader. Mätt med internationell måttstock är en mycket stor del av den vuxna befolkningen ute på arbetsmarknaden - både män och kvinnor.

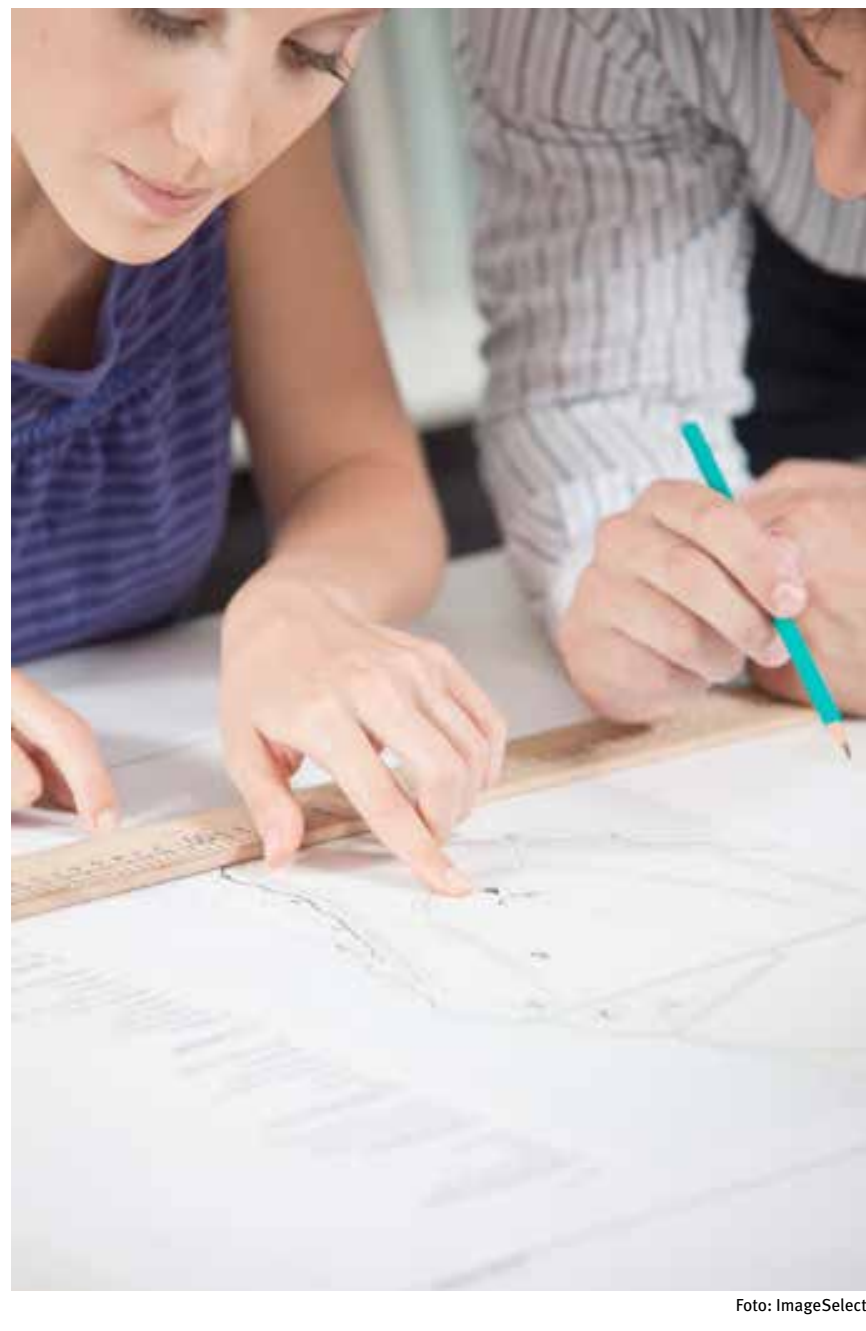

Labour market · Arbetsmarknad 


\section{Activity rates}

Activity rates are calculated as the number of people in the labour force between the ages of 15 and 64 as a percentage of all those between 15-64 years old. The Nordic countries have a high activity rate in general, compared to other European countries. For men, Alland has the lowest activity rate and the Faroe Islands the highest. For men, the activity rates range from 74 per cent in Åland to 89 per cent in the Faroe Islands - for women from almost 72 per cent in Greenland to more than 89 per cent in the Faroe Islands. The Nordic employment rates are also very high compared to the other West European countries.
Relativa arbetskraftstal

Relativa arbetskraftstal beräknas som antalet personer i arbetskraften mellan 15 och 64 år i procent av alla personer mellan 15 och 64 år. De nordiska länderna har generellt höga relativa arbetskraftstal jämfört med övriga europeiska länder. När det gäller män har Åland det lägsta relativa arbetskraftstalet och Färöarna det högsta. Relativa arbetskraftstal för män varierar från 74 procent för Åland till 89 procent för Färöarna - och i

fråga om kvinnor från nästan 72 procent för Grönland till drygt 89 procent för Färöarna. Den nordiska sysselsättningsgraden är också mycket hög jämfört med andra västeuropeiska länder.

Activity rate. Per cent of all 15-64-year-old

$$
\begin{array}{r}
100 \\
90 \\
80 \\
70 \\
60 \\
50
\end{array}
$$$$
80
$$

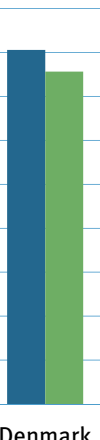
(1) ostat and national statistical institutes.
Employment rate. Per cent of all 15-64-year-old

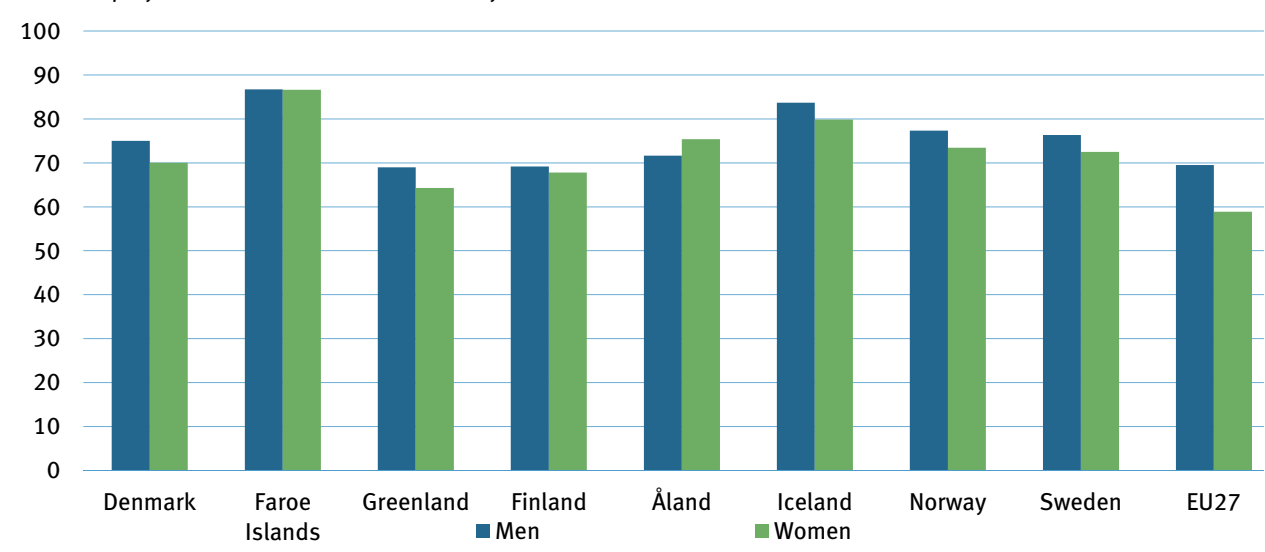


Unemployment

In 1990, almost half of all unemployed in the Nordic countries were Danes. However, when economic crises hit Sweden and Finland, including Åland, in the early 1990s, the unemployment rate increased drastically in these countries and changed the picture. From the mid-1990s and until about 2000, however, unemployment has decreased significantly in all the Nordic countries. Today the unemployment rate in all the Nordic countries is lower than the EU-average. As a result of the financial crisis, unemployment rates began to increase in the latter half of 2008 till 2010 in all the Nordic countries. Now the unemployment rate seems to have stabilized or even declined in some of the Nordic countries. Unemployment rates are calculated as the number of unemployed people as percentage of the labour force.

\section{Arbetslöshet}

År 1990 var uppemot hälften av alla arbetslösa i Norden danskar, men när ekonomiska kriser under de första åren av 90-tale drabbade Sverige och Finland, inklusive Åland, steg arbetslösheten dramatiskt i bägge länderna och ändrade bilden. Från mitten av 90-talet och fram till omkring år 2000 har arbetslösheten dock minskat markant i hela Norden. I dag ligger arbetslöshetsprocenten $\mathrm{i}$ alla nordiska länder under genomsnittet i EU-länderna. Som en följd av den ekonomiska krisen ökade arbetslösheten från andra halvåret av 2008 fram till $2010 \mathrm{i}$ alla nordiska länder. Nu tycks arbetslösheten ha stabiliserats eller till och med minskat i vissa av de nordiska länderna. Arbetslöshetstalen beräknas som antalet arbetslösa i procent av arbetskraften.

\section{Arbetslöshet}

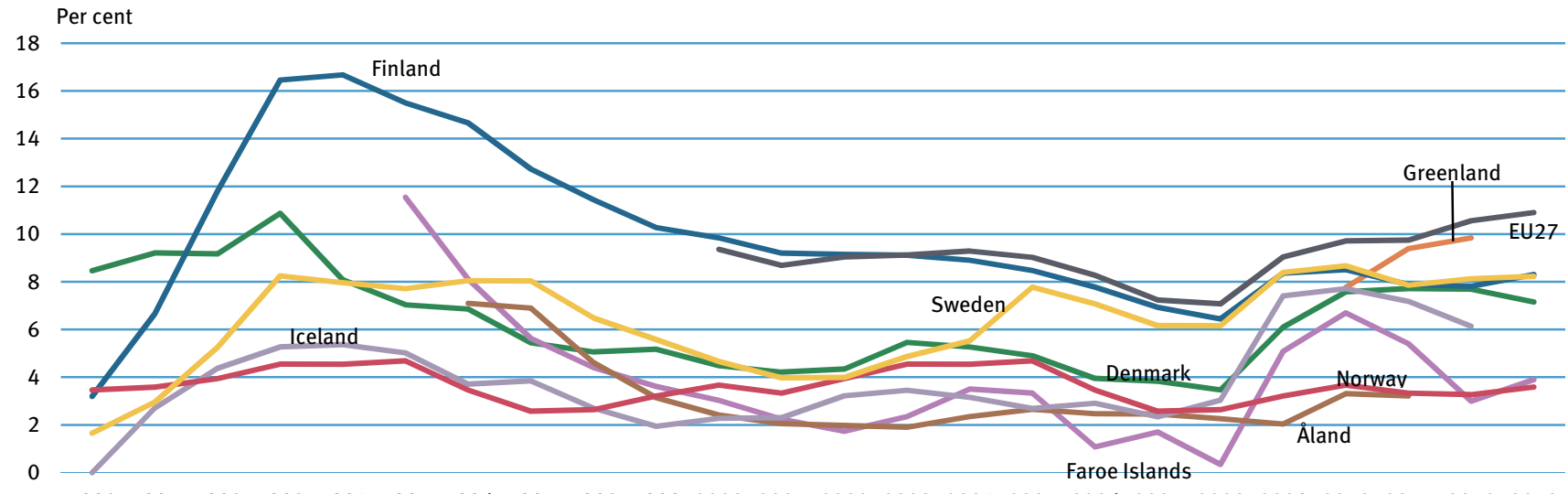

199019911992199319941995199619971998199920002001200220032004200520062007200820092010201120122013 ㅁ. Key01 and Work02

Source: National statistical institutes and Eurostat.

Not: EU-harmoniserade arbetslöshetstal med undantag av Äland och Island. Finland: Inkluderar Äland. EU27: De 27 medlemsstaterna i Europeiska unionen per 1 januari 2013. 


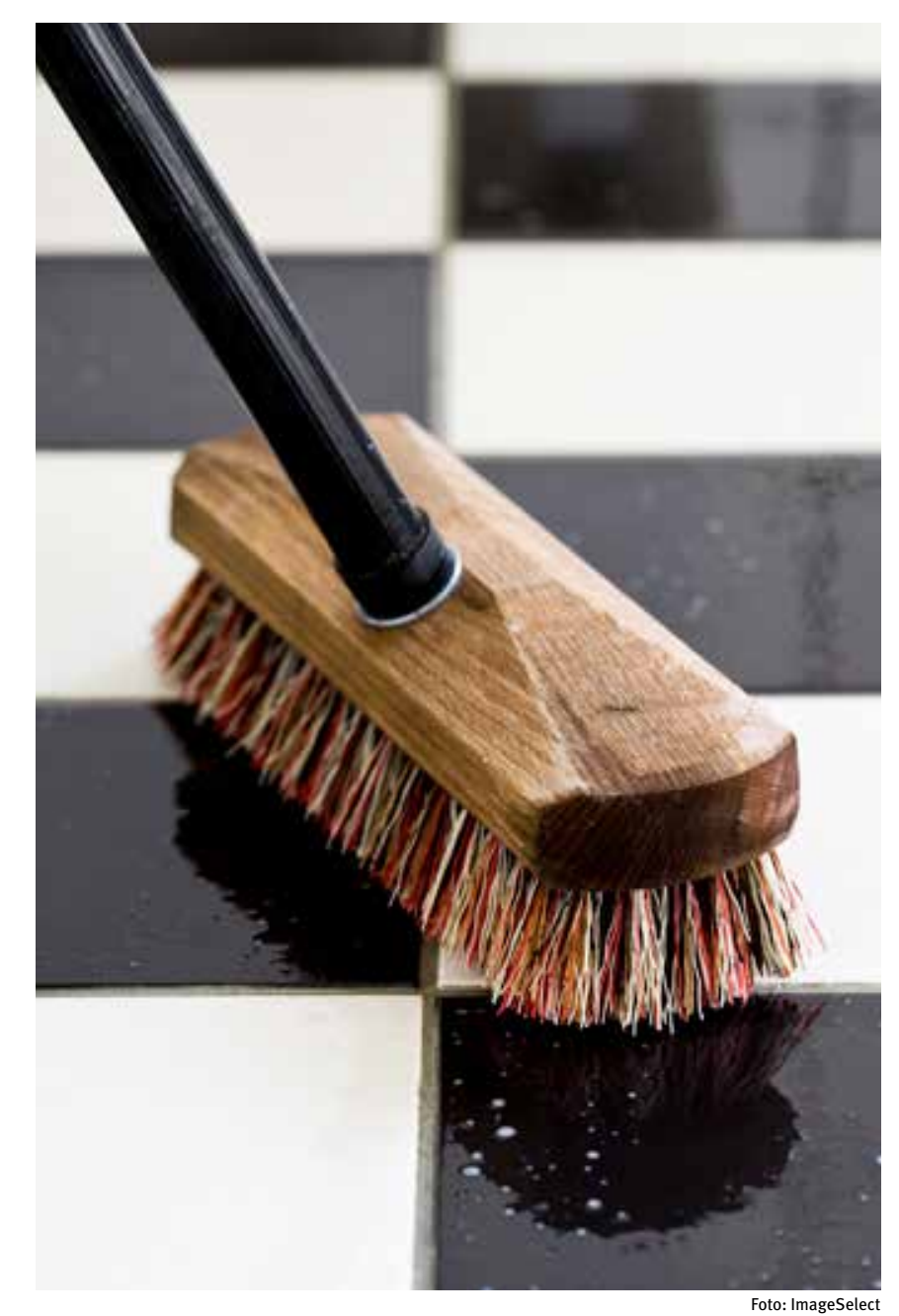

\begin{tabular}{|c|c|c|c|c|c|c|c|c|c|c|}
\hline & Denmark & $\begin{array}{r}\text { Faroe } \\
\text { Islands }\end{array}$ & $\begin{array}{l}\text { Green- } \\
\text { land }\end{array}$ & Finland & Åland & Iceland & Norway & Sweden & EU27 & \\
\hline $\begin{array}{l}\text { Per cent of } \\
\text { labour force }\end{array}$ & & & & & & & & & & $\begin{array}{r}\text { Procentav } \\
\text { arbetskraften }\end{array}$ \\
\hline Total & & & & & & & & & & Totalt \\
\hline Total & 7.2 & 3.9 & 9.8 & 8.3 & 3.2 & 6.1 & 3.6 & 8.2 & 10.9 & Totalt \\
\hline $15-19$ years & 15.8 & 15.4 & 20.7 & 29.6 & 11.8 & 16.2 & 12.3 & 36.7 & 27.6 & $15-19$ år \\
\hline $20-24$ years & 11.1 & 4.5 & 16.5 & 15.8 & 6.8 & 11.7 & 7.5 & 18.7 & 21.8 & $20-24$ år \\
\hline $25-34$ years & 8.6 & 3.1 & 10.8 & 7.9 & 3.2 & 6.6 & 4.2 & 8.1 & 12.7 & $25-34$ år \\
\hline $35-44$ years & 5.5 & 2.0 & 8.2 & 6.1 & 1.8 & 3.6 & 2.7 & 5.4 & 9.2 & $35-44$ år \\
\hline $45-54$ years & 5.2 & 2.4 & 8.3 & 5.9 & 3.0 & 3.6 & 2.0 & 4.9 & 8.1 & $45-54$ år \\
\hline $55-64$ years & 5.1 & 3.1 & 6.9 & 7.0 & 3.1 & 4.3 & 1.3 & 5.1 & 45.2 & $55-64$ år \\
\hline Men & & & & & & & & & & Män \\
\hline Total & 6.9 & 3.1 & 9.6 & 9.0 & 3.3 & 6.5 & 3.8 & 8.4 & 55.0 & Totalt \\
\hline $15-19$ years & 17.9 & 16.0 & 20.3 & 33.4 & 11.4 & 20.2 & 13.3 & 39.3 & 28.5 & $15-19$ år \\
\hline $20-24$ years & 11.8 & 2.4 & 14.5 & 19.3 & 7.9 & 11.1 & 9.3 & 20.1 & 22.3 & $20-24$ år \\
\hline $25-34$ years & 7.3 & 3.8 & 10.2 & 7.9 & 3.6 & 7.2 & 4.3 & 7.8 & 12.6 & $25-34$ år \\
\hline $35-44$ years & 4.9 & 1.1 & 8.0 & 6.0 & 1.8 & 3.2 & 2.5 & 5.4 & 8.7 & 35-44 år \\
\hline $45-54$ years & 5.3 & 0.7 & 8.5 & 6.7 & 2.6 & 3.9 & 2.1 & 5.0 & 8.1 & $45-54$ år \\
\hline $55-64$ years & 5.2 & 2.5 & 7.5 & 8.1 & 3.0 & 4.6 & 1.4 & 5.8 & 8.2 & $55-64$ år \\
\hline Women & & & & & & & & & & Kvinnor \\
\hline Total & 7.4 & 4.9 & 10.2 & 7.6 & 3.1 & 5.8 & 3.4 & 8.0 & 10.9 & Totalt \\
\hline $15-19$ years & 13.9 & 14.8 & 21.2 & 26.9 & 12.2 & 12.5 & 11.3 & 34.5 & 26.4 & $15-19$ år \\
\hline $20-24$ years & 10.2 & 7.7 & 19.1 & 11.9 & 5.5 & 12.3 & 5.6 & 17.0 & 21.2 & $20-24$ år \\
\hline $25-34$ years & 10.0 & 2.2 & 11.4 & 7.9 & 2.7 & 6.0 & 4.0 & 8.3 & 12.9 & $25-34$ år \\
\hline $35-44$ years & 6.2 & 3.1 & 8.4 & 6.1 & 1.9 & 4.0 & 2.9 & 5.3 & 9.8 & $35-44$ år \\
\hline $45-54$ years & 5.2 & 4.4 & 8.1 & 5.1 & 3.3 & 3.3 & 1.9 & 4.9 & 8.0 & $45-54$ år \\
\hline $55-64$ years & 5.1 & 3.8 & 5.9 & 5.9 & 3.1 & 4.0 & 1.2 & 4.2 & 6.9 & $55-64$ år \\
\hline
\end{tabular}

므 Work02

Note: Greenland and Iceland: 2012 data. Finland: Includes Åland. Åland: 2011 data. Iceland and Sweden: 16-19-year-old. EU27: The 27 member states of the European Union as per 1 Jonuary 2013.
Not:Gröland och Island: 2012 års uppgifter. Finland: Inkluderar Åland. Åland: 2011 års uppgifter. Island och Sverige: 16-19år. EU27: De 27 medlemsstaterna i Europeiska unionen per 1 januari 2013. 


\section{Youth unemployment}

The unemployment rate among the 15-24-year olds in the

Nordic countries - except in Finland - has risen to one of the highest levels since 1995. The increase did occur a couple of years prior to the financial crisis. The unemployment rate is especially high in Sweden where the rate in 2013 is 23.6 per cent and thus above the EU-average.

\section{Ungdomsarbetslöshet}

Arbetslösheten bland ungdomar i de nordiska länderna - utom i Finland - har stigit till en av de högsta nivåerna sedan 1995.

Ökningen skedde ett par år före den finansiella krisen. Ungdomsarbetslösheten är särskilt hög i Sverige där andelen år 2013 är

23,6 procent och därmed över EU-genomsnittet.

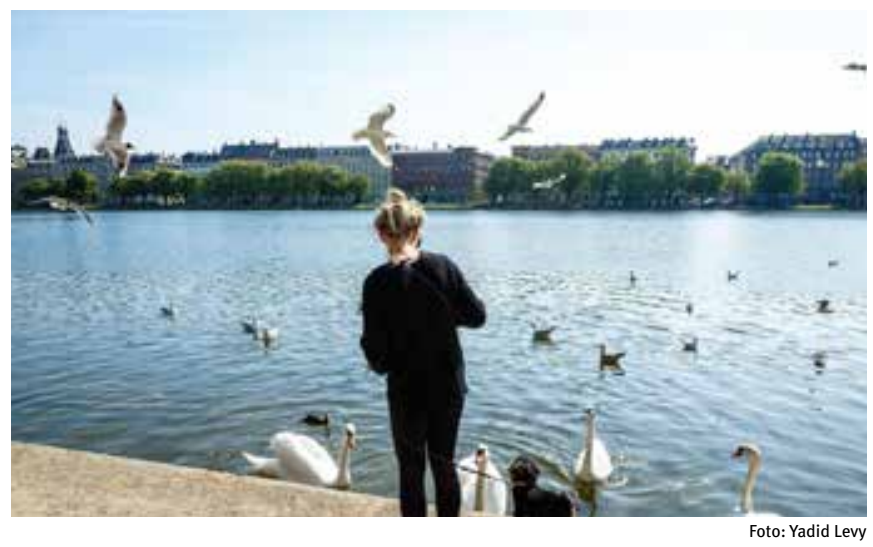

Arbetslöshet bland ungdomar i åldern 15-24 ar

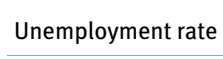

25

20

15

10

10

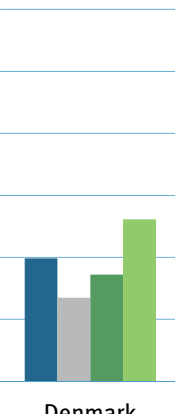

Denmark
Faroe Islands

- 1995

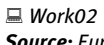

Source: Eurostat and national statistical institutes.

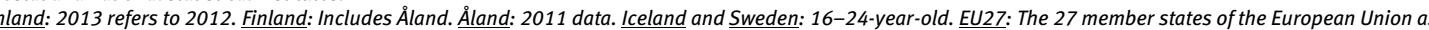
Nort 1 Ganuaryland: 2013 avser 2012 års uppgifter. Finland: Inkluderar Åland. Åland: 2011 års uppgifter. Island och Sverige: 16-24 år. EU27: De 27 medlemsstaterna i Europeiska unionen per 1 januari 2013 . 


\section{Employment by industry}

The labour market structure has changed considerably in recent decades. The Nordic countries have shifted from agrarian and industrial societies into societies dominated by a large service sector.

Employment in the public services (including education and defence) is the most common in the Nordic countries, more than 33 per cent of all are employed in this sector - women represent 74 per cent of these. The sector with the second most employed is wholesale and retail sale, transport, hotels and restaurants - 21 per cent are employed here, 58 per cent of these are men.
Men dominate in sectors as agriculture, manufacturing and constructing. Besides public services, women dominate in areas as other services and financial and insurance activities.

\section{Sysselsatta per näringsgren}

Arbetsmarknadsstrukturen har ändrats väsentligt under de senaste årtiondena. De nordiska länderna har gått från att vara jordbruksekonomier och industrisamhällen till att domineras av en stor tiänstesektor.

Offentlig sektor (inklusive utbildning och försvar) är den största sysselsättningssektorn i de nordiska länderna. Mera än 33 procent av alla är anställda i denna sektor - kvinnorna utgör 74 procent av dessa. Sektorn med näst mest anställda är parti- och detaljhandel, transport, hotell och restauranger - 21 procent är anställda här, 58 procent av dessa är män.

Männen dominerar inom sektorer som jordbruk och tillverkning samt $\mathrm{i}$ byggsektorn. Förutom inom offentliga sektorn dominerar kvinnorna också inom områden som övriga tjänster samt finansiell- och försäkringsverksamhet.

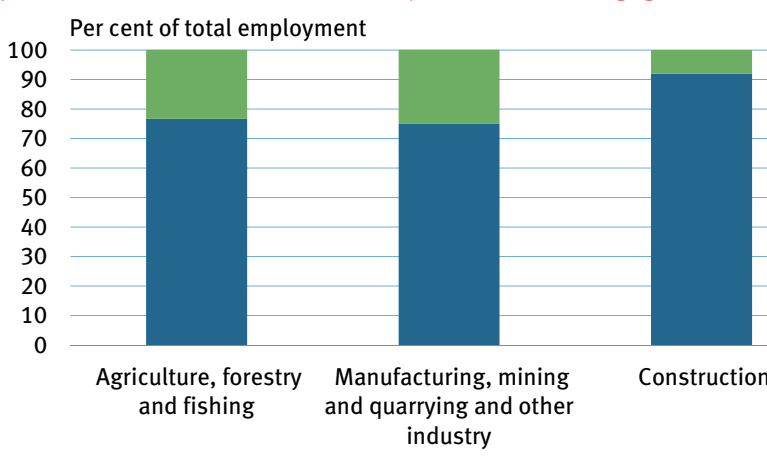

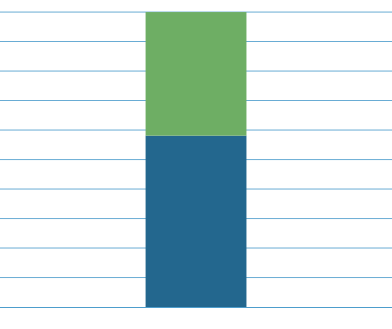

Wholesale and retail trade, transportatio commodation and food service activities

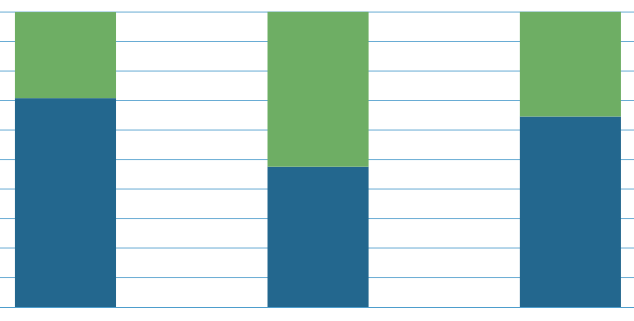

Information and communication

Financial and in activities

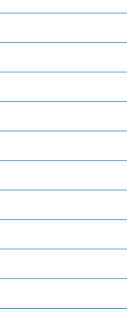

Professic echnical, support service activities

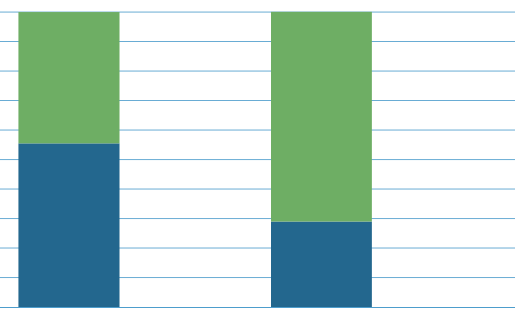

Public administration, defence, education, human health and 
Sysselsatta efter näringsgren

Denmark

Finland

Åland

Iceland

Norway

Sweden

EU27

1000 persons

Total

2622

2403

14

Per cent

Total

Men

Women

Total

Agriculture, forestry and fishing

Mining, quarrying and other industry

Manufacturing

Construction

Wholesale and retail trade, transport, restaurants and hotels

Information and communication

Financial and insurance activities

Real estate activities

Professional, scientific, technical, administration

and support service activities

Public administration, defence, education, human health

and social work activities

Other services

$\begin{array}{rrr}\mathbf{1 0 0 . 0} & \mathbf{1 0 0 . 0} & \mathbf{1 0 0 . 0} \\ 52.1 & 51.1 & 49.3 \\ 47.9 & 48.9 & 51.5 \\ \mathbf{1 0 0 . 0} & \mathbf{1 0 0 . 0} & \mathbf{1 0 0 . 0} \\ 2.4 & 4.0 & 4.4 \\ 1.4 & 0.3 & 0.7 \\ 12.5 & 15.0 & 7.3 \\ 6.1 & 7.5 & 6.6 \\ 23.1 & 22.3 & 26.3 \\ 4.2 & 4.3 & 3.6 \\ 3.0 & 2.1 & 2.9 \\ 0.9 & 0.9 & 0.7 \\ & & \\ 8.6 & 10.9 & 5.8 \\ & & \\ 34.8 & 29.3 & 36.5 \\ 2.6 & 3.1 & 3.6 \\ 0.2 & 0.4 & 1.5\end{array}$

므 Laboo1

Source: Eurostat and national statistical institutes.

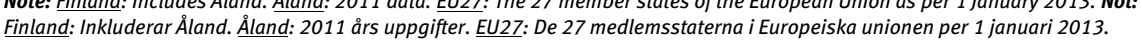

\begin{tabular}{rr}
165 & 25 \\
& \\
\hline 00.0 & 100.0 \\
51.9 & 52.4 \\
48.1 & 47.6 \\
00.0 & 100.0 \\
4.4 & \\
1.1 & \\
12.0 & \\
6.3 & \\
25.9 & 22.9 \\
4.5 & 4.3 \\
4.3 & \\
0.4 & \\
& \\
8.9 & \\
& \\
29.3 & \\
2.4 & 35.7 \\
0.4 & \\
\hline
\end{tabular}

4554

455

210974

1000 personer

520

100.0

$\begin{array}{ll}52.4 & \mathbf{1 0 0 . 0}\end{array}$

$\begin{array}{ll}52.4 & 52.1 \\ 47.6 & 47.9\end{array}$

100.0

2.1

3.9

9.1
7.8

22.3

4.2

2.2
0.9

9.5

2.5

35.7
1.9

0.3

4554

100.0
52.1
47.9
100.0
1.8
1.2
11.4
6.8
20.4
4.3
2.1
1.2

12.6

35.1
2.6
0.6

27

100.0

54.1
45.9

100.0

4.5

1.9

15.8

7.1
24.1

3.0

3.1
0.8

9.4

27.1

2.5
0.8

974

0.0
4.1
5.9
0.0
4.5
1.9
5.8
7.1
4.1
3.0
3.1
0.8
9.4

2.1
2.5
0.8

Totalt
1000 personer
Procent
Totalt
Män
Kvinnor
Totalt
Jordbruk, skogsbruk, jakt och fiske
Gruvor, stenbrott och annan industri
Tillverkning
Byggsektorn
Handel, transport, hotell- och restaurangverksamhet
Information och kommunikation
Finansiell- och försäkringsverksamhet
Fastighets- och företagstjänster
Professionella, vetenskapliga, tekniska, administrativa
och andra stödtjänster
Offentlig förvaltning, örsvar, utbildning, hälso-
och sociala tjänster
Övriga servicesektorn
Okänd
Okänd 


\section{Part-time employment}

The full-time/part-time distinction in the main job is made on the basis of a spontaneous answer given by the respondent in all the Nordic countries, except for Iceland and Norway, where part-time is determined on the basis of whether the usual hours worked are fewer than 35 .

Since 2000 , there has been an increase in people working parttime in all the Nordic countries. Only Iceland had a decrease in the number of women who have part-time jobs, which is also

reflected in the total number of people working part-time. Today 34 per cent of the working women in the Nordic countries have a part-time job.

In the Faroe Islands, 56 per cent of the working women work part-time. In Norway and Sweden it is respectively 41 and 38 per cent.

Finland have the fewest people in part-time jobs for both men and women - respectively 9 and 19 per cent.
Skillnaden mellan heltids- och deltidsarbete som huvudsyssla baserar sig på ett spontant svar från de som blivit tillfrågade i alla nordiska länder, förutom på Island och i Norge, där deltid bestäms på grund av huruvida de timmarna man vanligen arbetar är färre än 35.

Sedan 2000 har det skett en ökning av personer som arbetar deltid i nästan alla de nordiska länderna. Endast Island har haft en minskning av antalet kvinnor som har deltidsarbeten, vilket avspeglas också i det totala antalet personer som arbetar deltid. I dag har 34 procent av de arbetande kvinnorna i de nordiska länderna ett deltidsarbete.

På Färöarna arbetar 56 procent av de arbetande kvinnorna deltid. I Norge och Sverige är det 41 respektive 38 procent.

Finland har den minsta andelen personer i deltidsarbeten gällande både män och kvinnor - 9 respektive 19 procent.

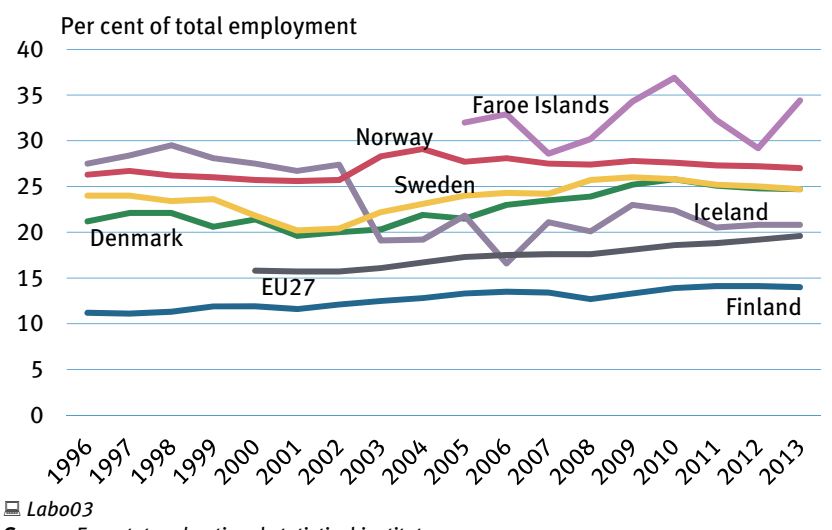

Part-time employment by sex. 2013 Figure 8.6 Deltidsanställning efter kön

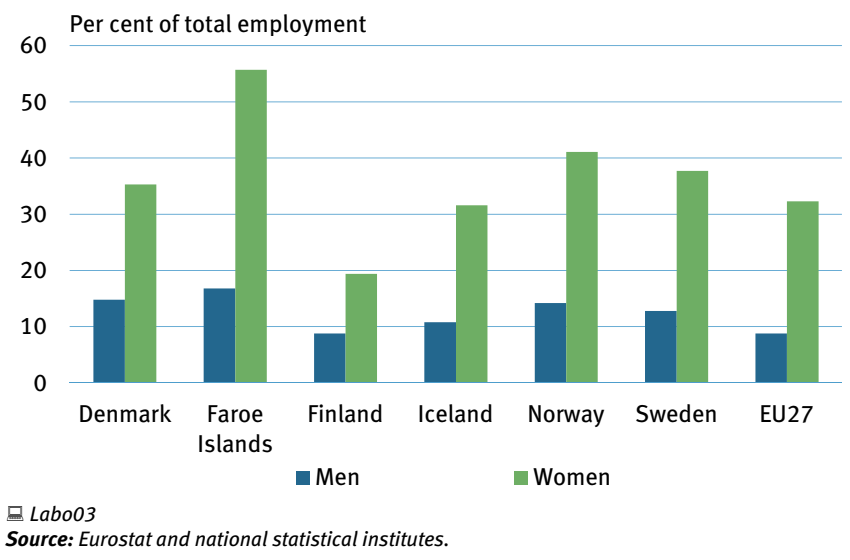




\section{Elections}

Val

Nordic parliaments are now all based on a one-chamber system. The Norwegian parliament did actually function as two separate chambers until 2009 when dealing with certain issues. The Icelandic Althing, founded in $930 \mathrm{AD}$, is reputed to be the oldest working parliament in the world.

In Denmark, Iceland and Sweden elections are held at least once every four years. Finland, Åland and Norway have fixed four-year election periods. Elections in the Faroe Islands and Greenland follow the Danish system of elections. The Danish Folketing has 179 seats, including two seats each for the Faroe Islands and Greenland. The Finnish Riksdag has 200 seats, including one seat for Alland. The Icelandic Althing has 63 seats, the Norwegian Storting 169 seats and the Swedish Riksdag 349 seats. The Faroese Lagting has 32 seats, Greenland's Landsting 31 seats and Åland's Lagting 30 seats.

Nordic citizens - and for the three member countries of the EU also EU-citizens - living in another Nordic country are normally entitled to vote in local government elections after a short period of residence; other foreign citizens have to reside in the Nordic countries for three to four years before they are eligible to vote.
De nordiska parlamenten bygger nu alla på enkammarsystem. Det norska parlamentet fungerade faktisk som två separata kammare till 2009 vid handläggningen av vissa frågor. Det isländska alltinget, som grundades 930 e. Kr., anses vara det äldsta fungerande parlamentet i världen.

I Danmark, på Island och i Sverige hålls val åtminstone en gång vart fjärde år. Finland, Åland och Norge har bestämda valperioder på fyra år. Valen på Färöarna och Grönland följer det danska valsystemet. Det danska folketinget har 179 ledamöter, inklusive två representanter var för Färöarna och Grönland. Den finska riksdagen har 200 ledamöter inklusive en representant för Åland. Det isländska alltinget har 63 ledamöter, det norska stortinget 169 ledamöter och den svenska riksdagen 349 ledamöter. Det färöiska lagtinget har 32 ledamöter, det grönländska landstinget har 31 ledamöter och Ålands lagting 30 ledamöter.

Nordiska medborgare - och för de tre medlemsländerna i EU också EU-medborgare - som bor i andra nordiska länder, har normalt rätt att rösta i kommunalval efter att ha bott $i$ landet under kort tid, medan andra utländska medborgare först måste bo i landet under tre till fyra år inan de får rätt att rösta.

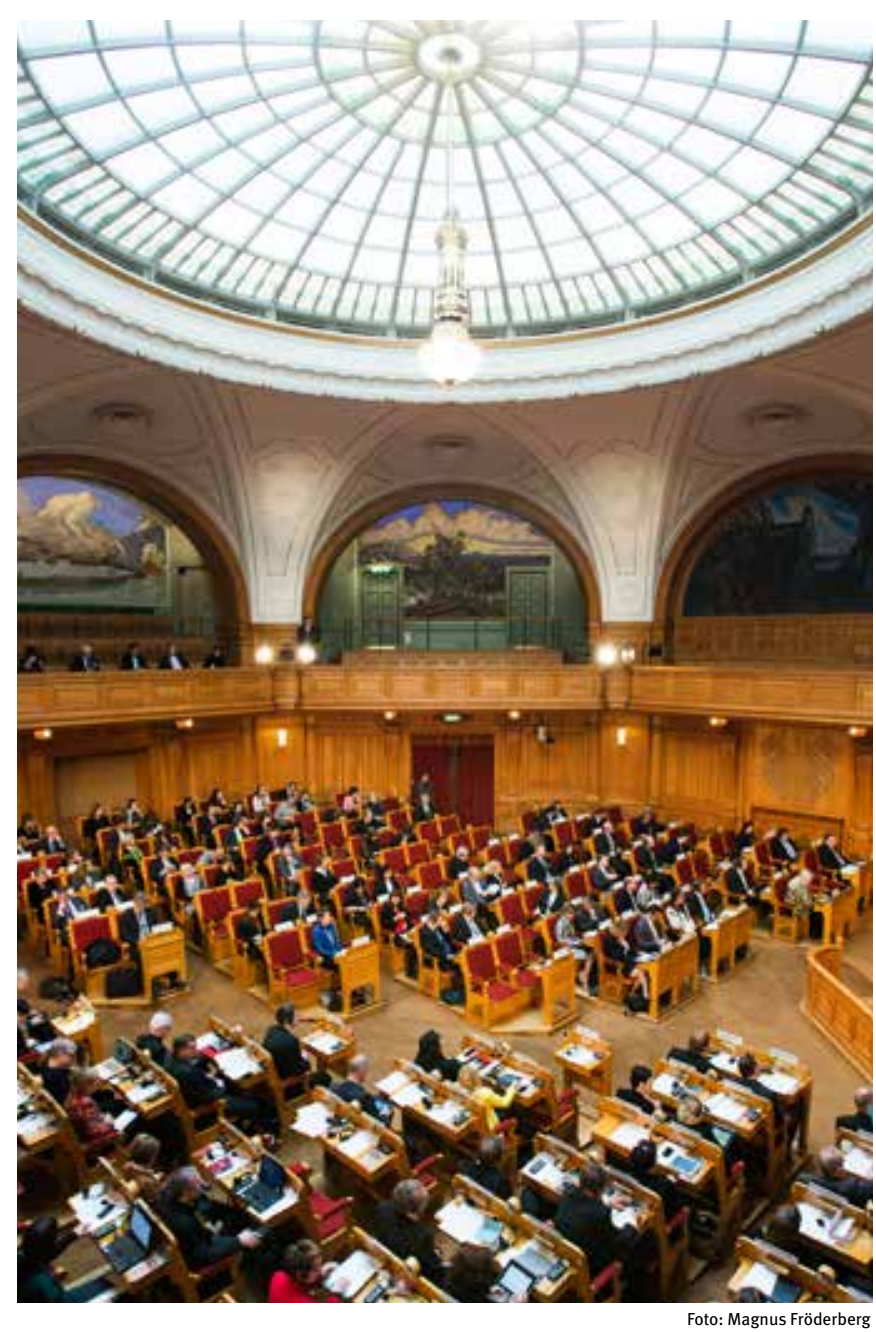

Foto: Magnus Fröderbers 


\section{Elections}

In Denmark and the Faroe Islands, people are the most eager at the ballot box, as the percentage of electorates is close to 90 per cent. Voters in Åland and Finland are the least eager, which is reflected in the percentage of electorates, which is around 67 per cent.

Men are more often elected to the national assembly compared to women. The biggest bias between the two sexes is seen in the Faroe Islands and Åland, while in Sweden, men and women are close to being equally represented in the national assembly.

Turnout at the last two national elections

Figure 9.1 Valdeltagandet vid de två senaste nationella valen

$$
\text { Per cent }
$$$$
100
$$

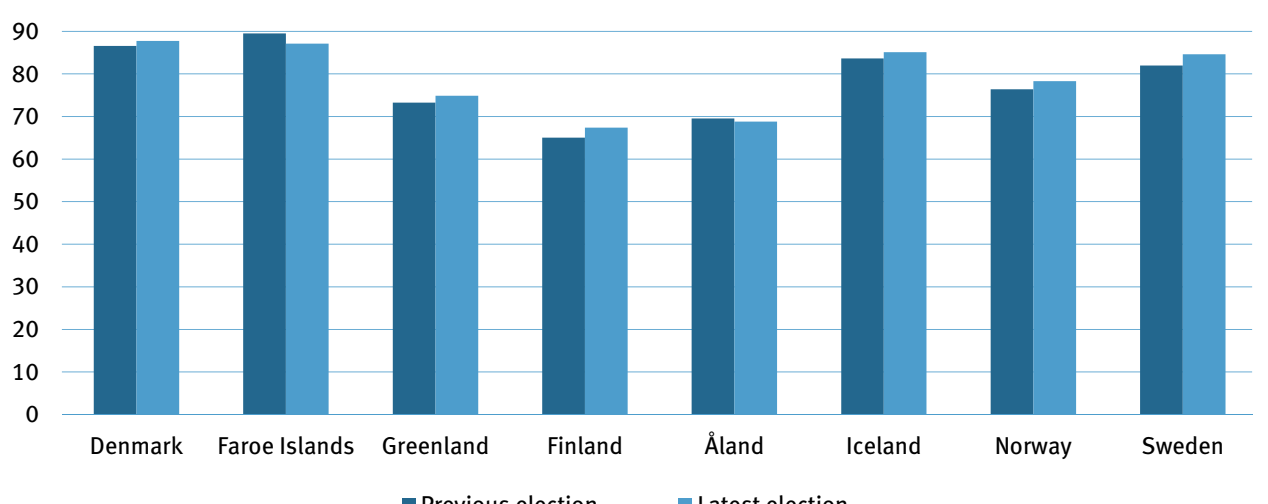

미이

- Previous election

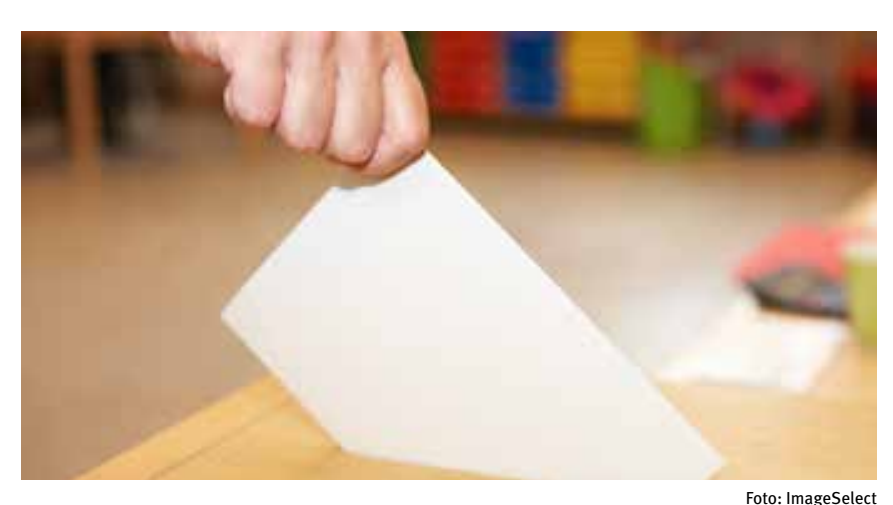

Foto: ImageSelect
Val

I Danmark och på Färöarna är människorna mest angelägna vid valurnorna och andelen röstande är nära 90 procent. Väljarna på Åland och i Finland är de minst angelägna, och valdeltagandet är runt 67 procent i dessa länder.

Det är fortfarande fler män än kvinnor som väljs in till de nationella parlamenten. Den största skillnaden mellan könen ses på Färöarna och Åland, medan svenska män och kvinnor har nästan lika stor representation i nationalförsamlingen.

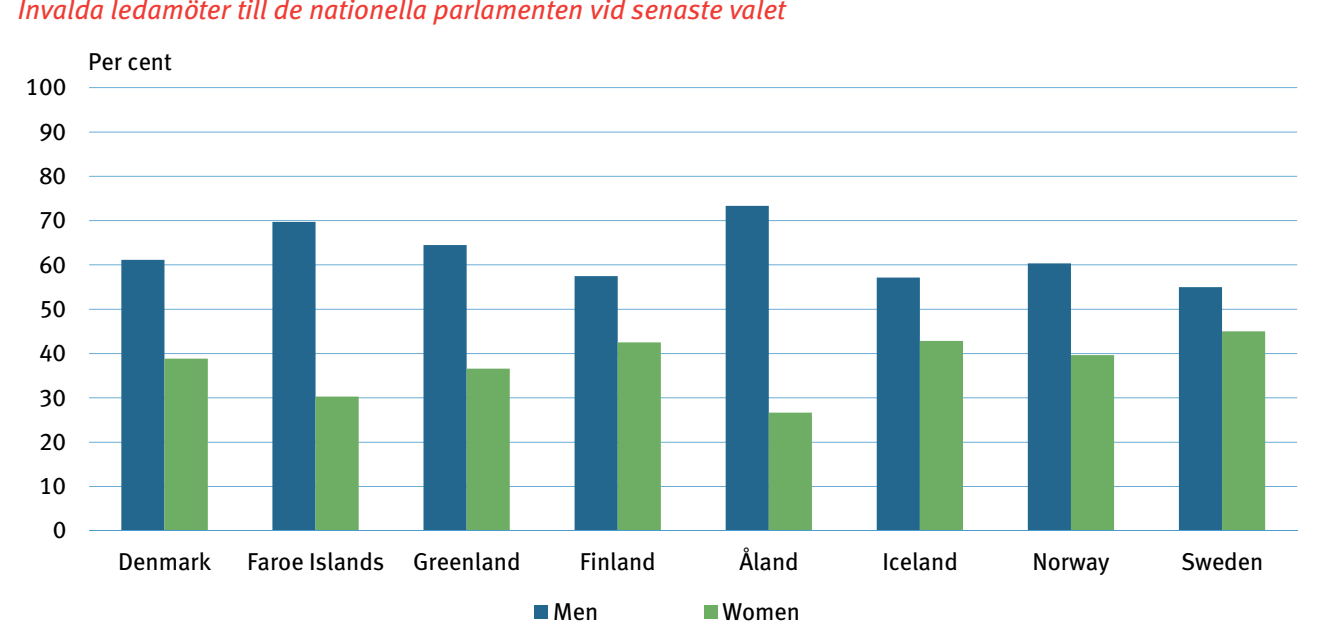
•Women 


\section{Elections to the European Parliament}

Every fifth year, the three Nordic members of EU, Denmark, Finland and Sweden, go to the ballots to vote for their national members of the European Parliament. Denmark and Finland have 13 seats in the European parliament each, while Sweden has 18 seats. Due to the expansion of EU, the number of seats to each country has been reduced since 1999 .

In Denmark, people are the most eager to go to the ballots, almost 60 per cent voted in 2014. In Sweden, around 50 per cent voted. In Finland it was around 40 per cent. Women accounted for more than half of the elected members to the European Parliament in both Finland and Sweden. In the previous election (2009), women had the majority of the votes in all three member states.

\section{Val till Europaparlamentet}

Vart femte år går de tre nordiska medlemmarna i EU, Danmark, Finland och Sverige, till valurnorna för att rösta fram sina representanter till Europaparlamentet. Danmark och Finland har 13 platser var i det europeiska parlamentet, medan Sverige har 18 platser. Antalet platser för varje land har minskats sedan 1999 , till följd av utvidgningen av EU.

Folk är mest angelägna om att gå till valurnorna i Danmark, där nästan 60 procent röstade 2014. I Sverige röstade kring 50 procent och i Finland var det kring 40 procent. År 2014 svarade kvinnor för mer än hälften av de invalda ledamöterna till Europaparlamentet i Finland och Sverige. I det föregående valet (2009) fick kvinnor en majoritet av rösterna i alla tre medlemsstater.
Valid votes at the latest European elections Giltiga röster vid de senaste europeiska valen

Figure 9.3

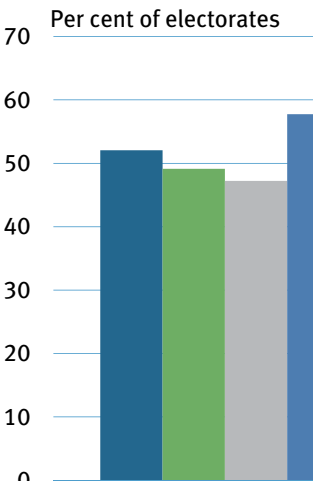

Denmark

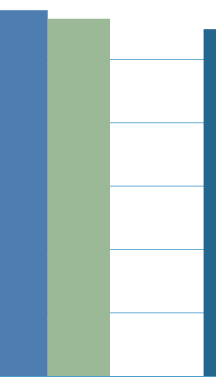

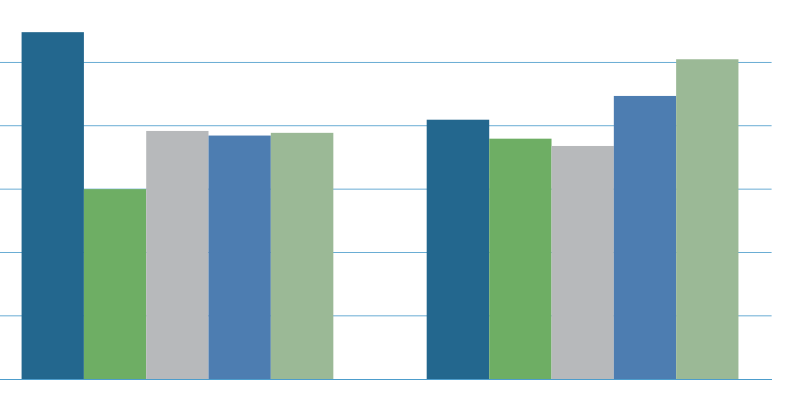

Finland
Sweden

- $1994 \square 1999 \square 2004 \quad \square 2009 \square 2014$

Candidates elected to the European Parliament Invalda ledamöter till Europaparlamentet

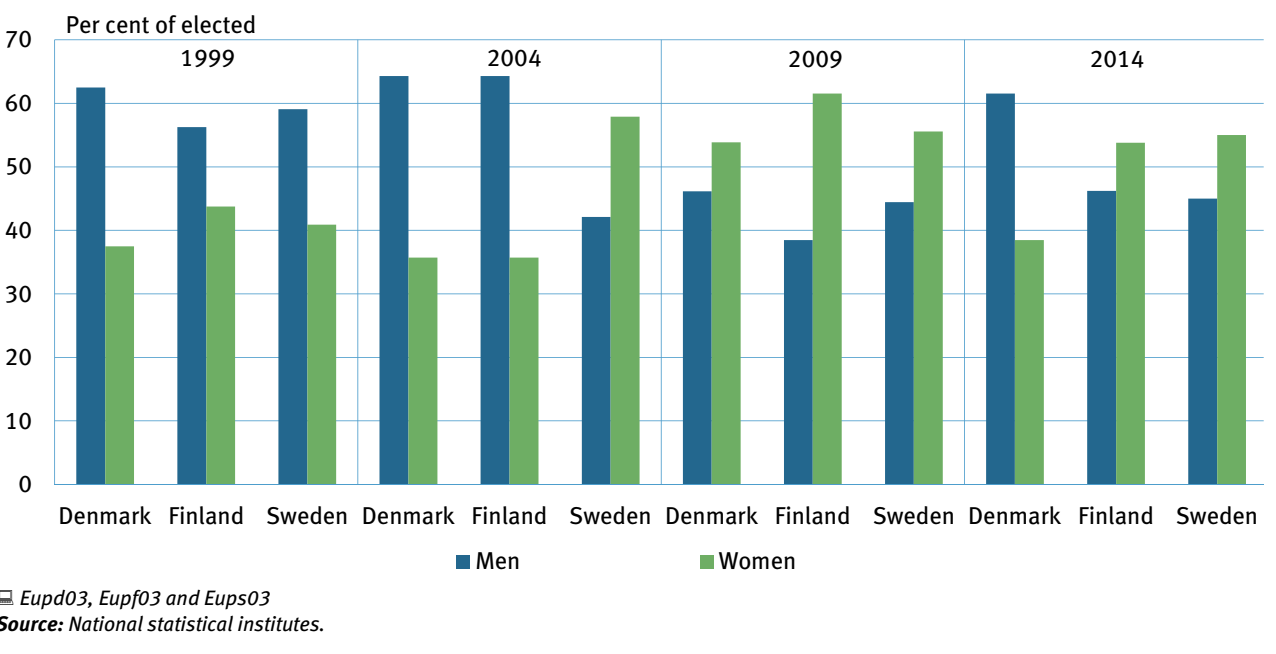




\section{Culture \\ Kultur}

Culture is one of the main components of co-operation between the Nordic countries, and has long acted as a bridge, improving understanding of the neighbouring peoples and the shared values.

The policies of the Nordic countries with respect to cultural life, mass media and religion have many features in common. However, some differences may be pointed out - for instance, cultural institutions arising from historical circumstances.

In both Denmark and Sweden, there are cultural institutions with roots in the traditions of the royal courts. In these countries, national institutions formed the foundation of cultural life at an early stage while, in Norway, cultural institutions began to form later.
Kultur är en av de viktigaste komponenterna i samarbetet mellan de nordiska länderna och har länge fungerat som en bro som förbättrat förståelsen för grannfolken och de gemensamma värderingarna.

De nordiska länderna har en ganska likartad inställning till kulturellt liv, massmedier och religion. Vissa skillnader kan emellertid urskiljas, exempelvis när det gäller kulturella institutione som har sin grund $i$ historiska förhållanden.

Både i Danmark och Sverige finns institutioner som har rötter i traditionerna kring det kungliga hovet. Där bildade kulturinstitutionerna grunden för det kulturella livet på ett tidigt stadium, medan de började ta form först senare i Norge.

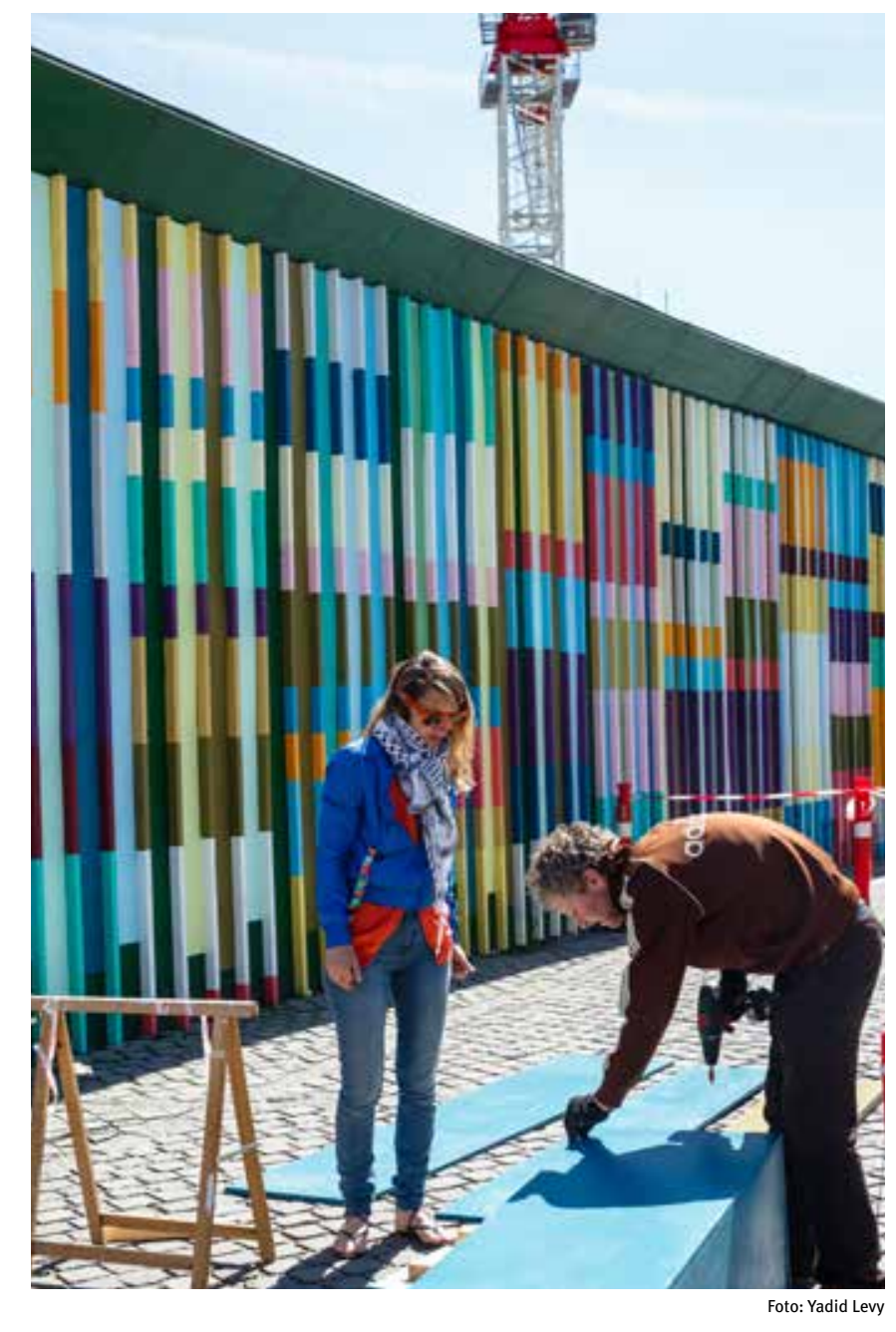


Government expenditure on culture and leisure

Iceland is the Nordic country that has the highest government expenditure on culture - a total of 3.3 per cent of GDP. Denmark comes second with a total of 1.6 per cent of GDP. Sweden spends the least with 1.1 per cent. Looking at per capita expenditure Iceland again has the highest expenditure but with Norway coming second. Greenland spends the third highest amount on culture and leisure per capita.

In Iceland and Norway, expenditures have more than doubled since 2000. In the other Nordic countries, expenditures have

"only" gone up between 40 and 50 per cent in the same period.
Offentliga utgifter för kultur och fritid

Island är det nordiska land som har de högsta offentliga utgifterna för kultur - totalt 3,3 procent av BNP. Danmark kommer på andra plats med totalt 1,6 procent av BNP. Sverige spenderar minst med 1,1 procent. Tittar vi på utgifter per person har Island igen störst kostnader men med Norge som tvåa. Grönland spenderar det tredje högsta beloppet på kultur och fritid per capita.

På Island och i Norge har utgifterna mer än fördubblats sedan år 2000. I de övriga nordiska länderna har utgifterna "bara" gått upp mellan 40 och 50 procent under samma period.

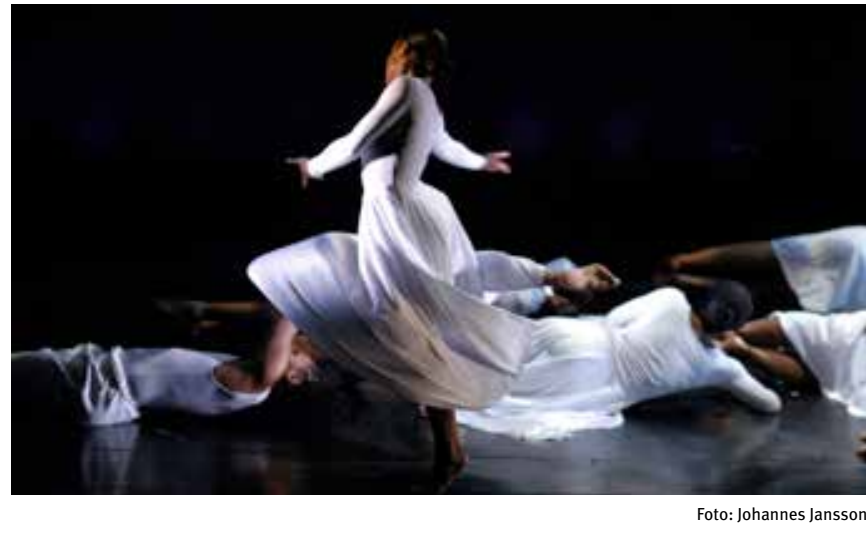

Table 10.1

Government expenditure on culture and leisure. 2012

Offentliga utgifter för kultur och fritid

Recreation, culture and religion, total

Million euro

Euro per capita

Per cent of GDP

Per cent of expenditure on culture and leisure

Recreation, culture and religion, total

Recreational and sporting services

Cultural services

Broadcasting and publishing services

Religious and other community services

$R \& D$, recreation, culture and religion

Recreation, culture and religion, no

elsewhere classified

C Cult2o

Source: Eurostat, national statistical institutes and the Swedish Agency for Cultural Policy Analysis. Note: Finland: Includes Aland. Faroe Islands: 2009 data.

$\begin{array}{llllll}\text { Denmark Faroe Islands } & \text { Greenland } & \text { Finland } & \text { Iceland } & \text { Norway } & \text { Sweden }\end{array}$

$\begin{array}{rrrr}3858 & 20 & 48 & 2419 \\ 691 & 414 & 856 & 447 \\ 1.6 & 1.2 & . . & 1.4 \\ & & & \\ 100.0 & 100.0 & 100.0 & 100.0 \\ 26.2 & 36.0 & 15.1 & 39.4 \\ 41.8 & 34.7 & 51.5 & 45.4 \\ -. & 8.0 & -. & 0 . \\ 29.4 & 7.4 & 20.1 & 15.0 \\ - & - & - & 0.1 \\ 2.6 & 13.4 & 13.3 & \end{array}$

2419
447
1.4

100.0
39.4
45.4
0.1
15.0
0.1

-

348
1084
3.3

100.0

100.0
45.4

45.4
34.6

9.4
9.5

9.5
1.0

0.1

4739
944
1.3

100.0
10.0
39.4
0.9
22.8
0.1
26.8

Sweden

4469
Rekreation, kultur och religion, totalt Miljoner euro Euro per person Procent av BNP Procent av utgifter för kultur och fritid 100.0 Rekreation, kultur och religion, totalt $45.8 \quad$ Fritids- och idrottsverksamhet
Kulturella tjänster Religiösa och andra kommunala tjänster FoU, fritidsverksamhet, kultur och religion Rekreation, kultur och religion som ej
klassificeras annorstädes 


\section{Museums}

Denmark has the most museums, a total of 258 , but museums in Åland and Iceland have the most visitors - an average of 4 and 5 visits per inhabitant respectively.

\section{Museer}

Danmark har flest museer, totalt 258, men det är museer på Åland och Island som har flest besökare - i genomsnitt nästan 4 respektive 5 besök per invånare.

Number of visits to museums. 2013 Figure 10.1

Antal museibesök

Visits per person

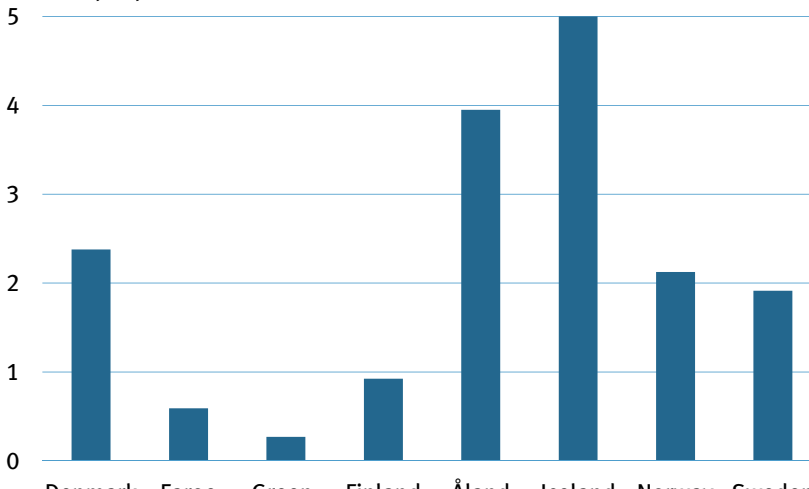

Denmark Faroe Green- Finland Åland Iceland Norway Sweden Islands land

\section{Cult16}

(ional statistical institutes.

Note: Faroe Islands: Data only cover national museums, not local museums.

Iceland: 2010 data. Greenland, Finland and Sweden: 2012 data. Iceland: 2011 data.

Not. aroarna: Uppgifferna omfattar endast nationella museer, inte lokala museer. Island: 2010 års uppgifter. Grönland, Finland och Sverige: 2012 års uppgifter. Island: 2011 års

94 Culture $\cdot$ Kultur

\section{Theatres}

Many theatres in the Nordic countries receive public funding. Theatre funding constitutes a major share of allocations within the cultural area in all the countries. All countries have national theatres, where plays, ballets and operas are performed. In addition to the national theatres, there are professional regiona theatres, which are also supported by the state, counties or municipalities. Most countries also have a few private theatres and many amateur ensembles, which may be supported, at least partially, by municipalities, primarily.

\section{Teatrar}

Många teatrar i de nordiska länderna får offentliga bidrag. Bidrag till teatrar utgör huvuddelen av bidragen inom det kulturella området $\mathrm{i}$ alla länderna. Alla länder har nationella teatrar, där teaterpjäser, balett och opera uppförs. Utöver de nationella teatrarna finns professionella regionala teatrar som också uppbär bidrag från stat, landsting eller kommuner. Flertalet länder har också några privatteatrar och många amatörensembler som ibland får bidrag, i vart fall delvis, av i första hand kommunerna.
Theatres. 2013

Table 10.2

Teatrar

\begin{tabular}{lrrrrrrrr} 
& Denmark & Faroe Is. & Greenland & Finland & Iceland & Norway & Sweden & Antal \\
\hline Number & & & & & & & & \\
Theatres & 96 & 1 & 2 & 130 & 4 & 32 & 141 & Teatrar \\
Performances & 11246 & 119 & 60 & 19573 & 1072 & 10400 & 21416 & Föreställningar \\
Visitors & 2073000 & 9716 & 23705 & 3164822 & 287172 & 1806042 & 3036737 & Besökare \\
Visits per 100 inhabitants & 37.0 & 20.1 & 42.0 & 58.5 & 89.5 & 35.6 & 32.4 & Antal besök per 100 invånare \\
\hline
\end{tabular}




\section{Sale of music}

Since 2000, the total sale of music has declined by between 40 and 60 per cent in the Nordic countries, at the same time the digital sale has increased dramatically. In Norway sales by digital channels have increase 18 -fold since 2006. Sales of digital music account for between 32 and 78 per cent of total sales in 2013, Iceland being the exception with a proportion of around 11 per cent.

Digital sales cover both downloads and streaming of music.
Musikförsäljning

Sedan 2000 har den totala försäljningen av musik minskat med mellan 40 och 60 procent i samtliga nordiska länderna. Samtidigt har den digitala försäljningen ökat dramatiskt. I Norge har den försäljningen via digitala kanaler blivit 18 gånger större sedan år 2006.Försäljningen av digital musik utgör mellan 32 och 78 procent av den totala försäljningen under 2013 med undantag av Island som har en andel kring 11 procent.

Digital försäljning omfattar både nedladdning och streaming av musik.

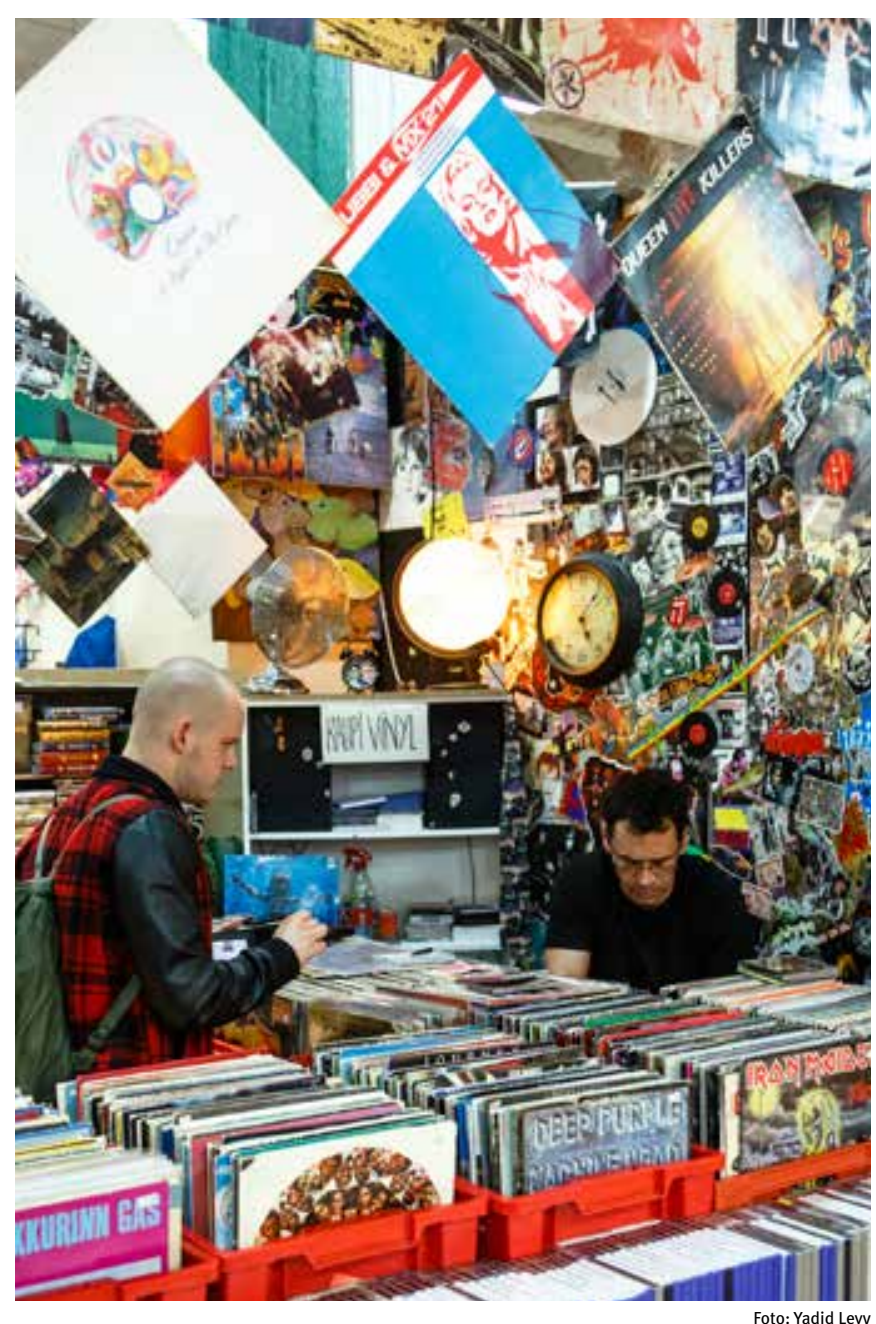

Sale of music. 2013 Musikförsäljning

\begin{tabular}{|c|c|c|c|c|c|c|}
\hline & Denmark & Finland & Iceland & Norway & Sweden & \\
\hline 1000 euro & & & & & & 1000 euro \\
\hline Total sale & 57573 & 42441 & 3310 & 77209 & 114954 & Total försäljning \\
\hline Via digital channels & 36946 & 13722 & 373 & 59923 & 86986 & Via digitala kanaler \\
\hline Percent & & & & & & Procent \\
\hline Total sale & 100 & 100 & 100 & 100 & 100 & Total försäljning \\
\hline Via digital channels & 64.2 & 32.3 & 11.3 & 77.6 & 75.7 & Via digitala kanaler \\
\hline
\end{tabular}

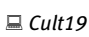

Source: IFPI (International Federation of the Phonographic Industry) and Statistics I celand.

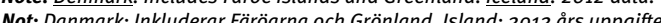

Table 10.3 


\section{Libraries and books}

Traditionally, libraries lent out volumes of books, which was fairly easy to tabulate. Today, libraries function as information centres with a wide variety of services and access to all kinds of printed and electronic media.

In the last twenty years, there has been an overall decline in stock and lending of books in public libraries. Despite the general decline in stock and loans, most of the Nordic countries have had an increase in the lending of other media than books.
Since 2000 the stock of other media has increased between 30 and 80 per cent in the Nordic countries. The lending of books has at the same time decreased in all Nordic countries - a decline between 10 and 20 per cent.

Bibliotek och böcker

Bibliotek har traditionellt lånat ut böcker, vilket har varit ganska enkelt att räkna. I dag fungerar bibliotek som informations centra med ett brett utbud av tjänster och tillgång till alla typer av tryckta och elektroniska medier.
Under de senaste tjugo åren har det skett en allmän nedgång bestånd och utlåning på folkbibliotek. Trots den allmänna nedgången $\mathrm{i}$ bestånd och utlåning har de flesta nordiska länderna haft en ökning av utlån av andra medier än böcker.

Sedan 2000 har beståndet av andra medier ökat mellan 30 och 80 procent i de nordiska länderna. Utlåningen av böcker har samtidigt minskat i alla nordiska länder - en minskning mellan 10 och 20 procent.
Total lending in public libraries Utlåning på folkbiblioteken

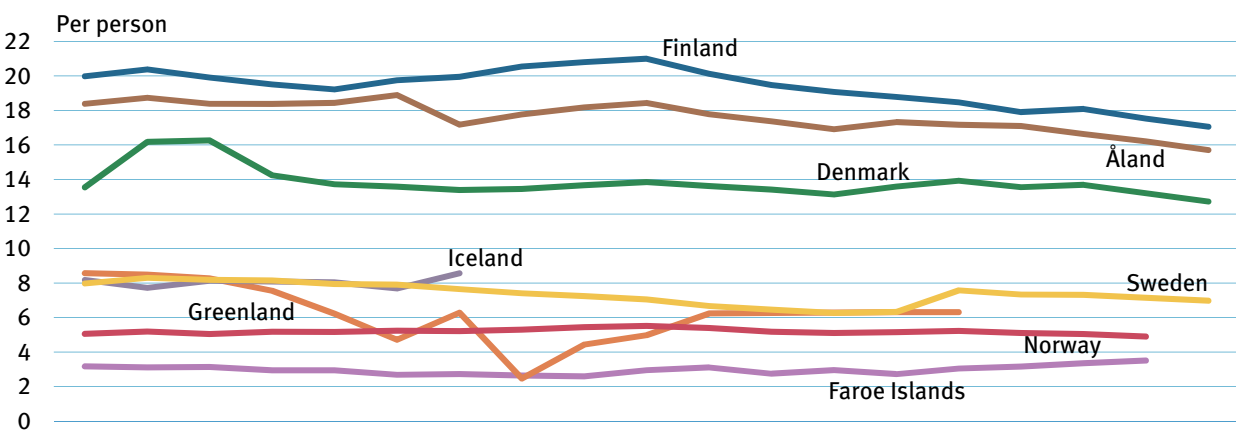

1995199619971998199920002001200220032004200520062007200820092010201120122013 a Culto1 and Popu02

Source: National statistical institutes and the National Library of Finland.
Lending of other media than books in public libraries, per person Figure 10.3 Utlåning av andra media än böcker på folkbiblioteken, per person

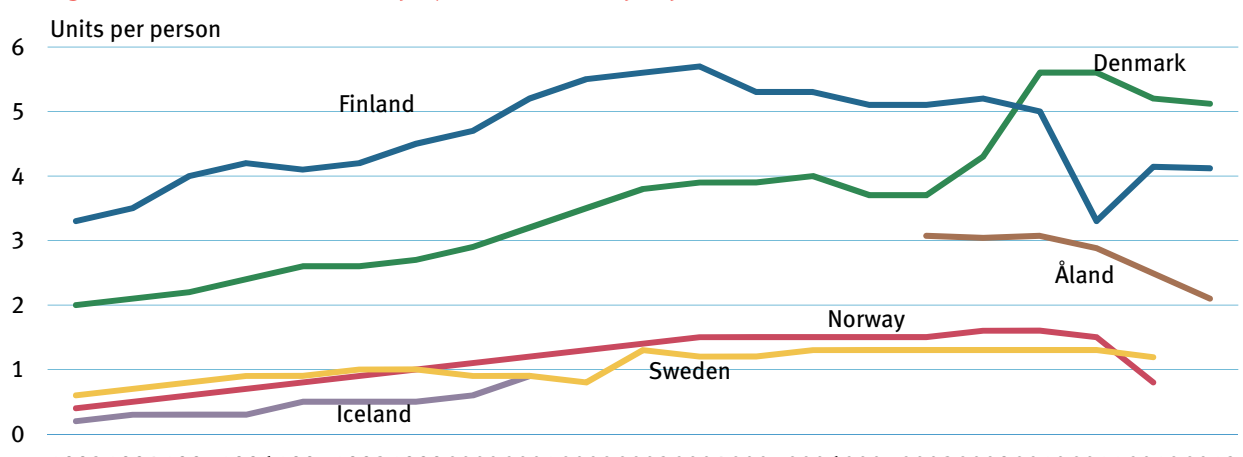

199319941995199619971998199920002001200220032004200520062007200820092010201120122013

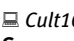

Source National statistical institutes. 


\section{The Economy \\ Ekonomi}

The over-arching objectives for Nordic co-operation are stable and sustainable economic growth; development of the Nordic welfare model; economic integration in the Nordic region, the Baltic Sea region and Europe; and the promotion of joint Nordic interests at international level.

2007 marked the beginning of the financial crisis throughout the world. All the Nordic countries have been affected by the global crisis though to varying degrees. GDP growth was negative in all of the Nordic countries in 2008 and 2009. From 2009 most of the Nordic countries experienced growth again.

The Nordic economies are among the countries in the Western World with the best macroeconomic performance in the recent ten years. Denmark, Norway and Sweden have for example experienced constant and large excess exports in recent years. Finland is the only country which has balance of payments deficits (2013). At the same time, unemployment is low in most of the Nordic countries compared with the rest of Europe. As a result of the cyclical down-turn, the public balance is now in deficit, except for Norway.
De övergripande målen för samarbetet i Norden är att verka för en stabil och hållbar ekonomisk tillväxt, att verka för utvecklingen av den nordiska välfärdsmodellen, att främja den ekonomiska integrationen inom Norden och med Östersjöregionen och Europa samt att främja gemensamma nordiska intressen internationellt.

2007 markerade inledningen på den ekonomiska krisen i hela världen. Alla nordiska länder har varit berörda av den globala krisen om än i olika utsträckning. BNP-tillväxten var negativ i alla de nordiska länderna under 2008 och 2009. Från 2009 upplevde de flesta nordiska länder igen tillväxt.

De nordiska ekonomierna är bland de länder i västvärlden som har haft de bästa makroekonomiska resultaten av alla under de senaste tio åren. Danmark, Norge och Sverige har till exempel upplevt varaktiga och betydande export-överskott under de senaste åren. Finland är det enda land som har underskott $i$ betalningsbalansen (2013). Samtidigt är arbetslösheten låg i de flesta av de nordiska länderna jämfört med övriga Europa. Som en följd av den cykliska nedgången visar nu de offentliga finanserna ett underskott, med undantag för Norge.

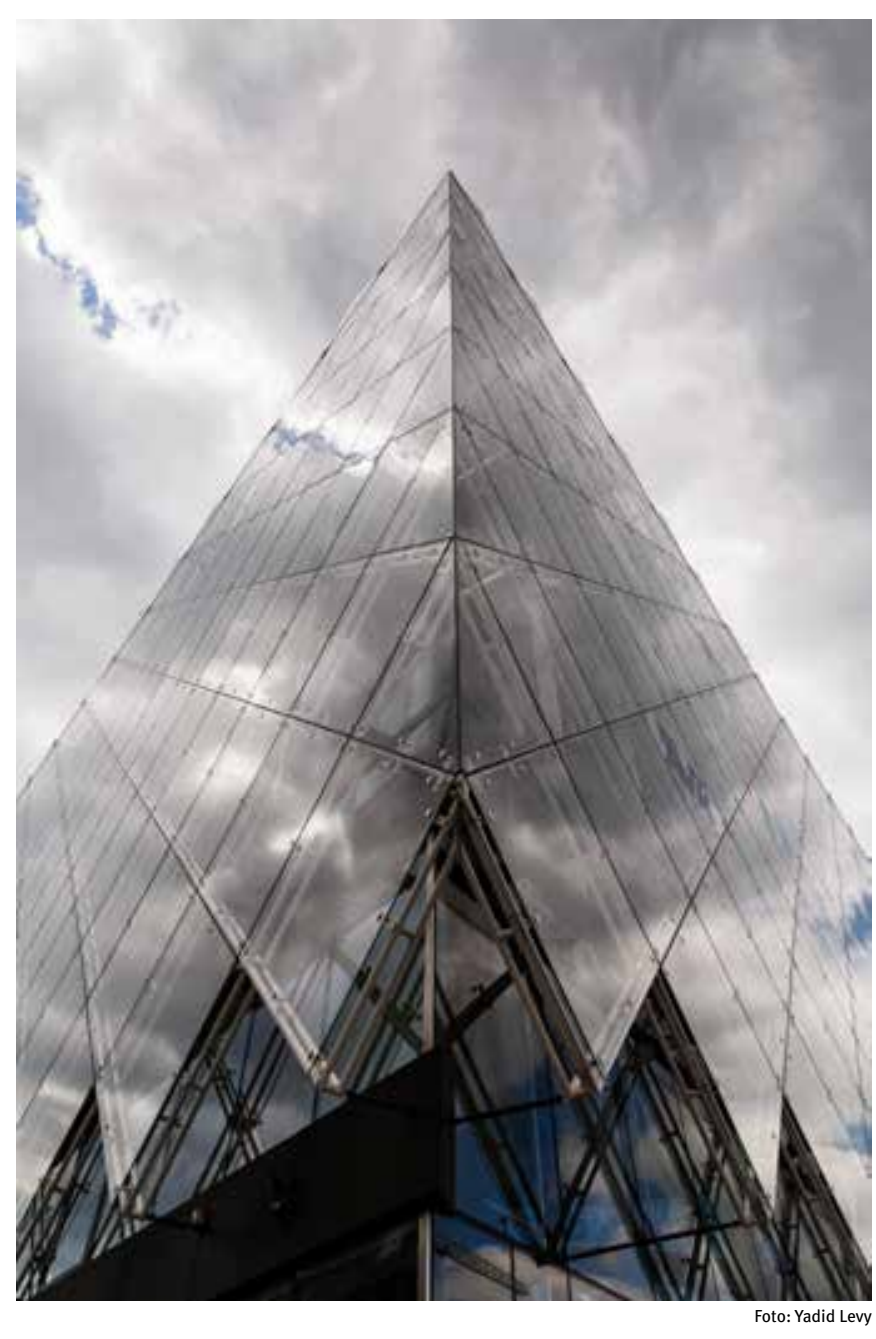

The Economy · Ekonomi 


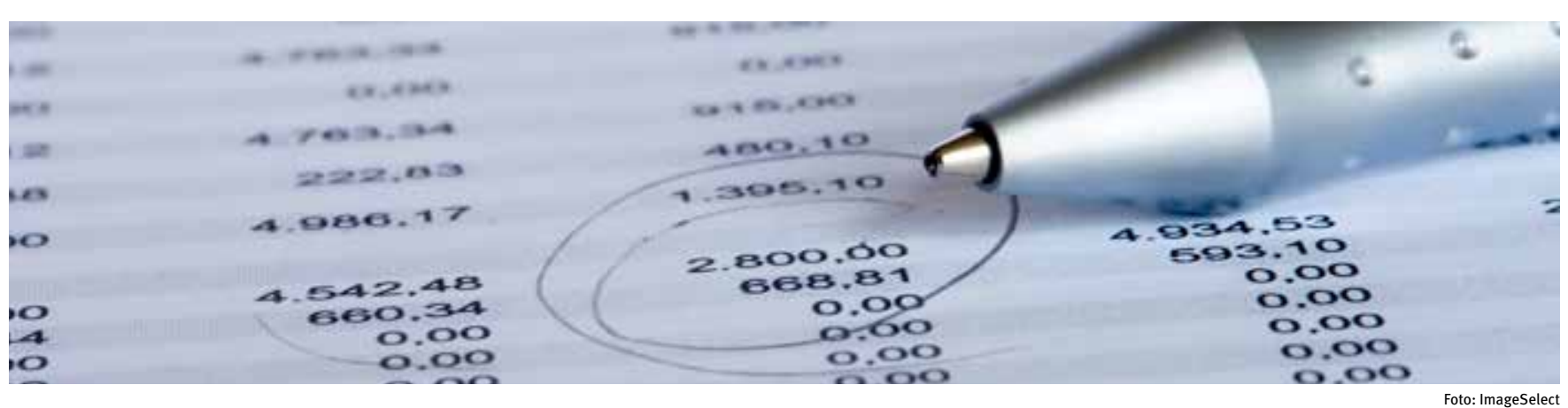

Economic key figures. 2013 or latest available figures

Foto: Imageselect

Ekonomiska nyckeltal. 2013 eller senast tillgängliga uppgifter

\begin{tabular}{|c|c|c|c|c|c|c|c|c|c|}
\hline & Denmark & Faroe Islands & Finland & Åland & Iceland & Norway & Sweden & EA17 & \\
\hline Per cent of GDP & & & & & & & & & Procent av BNP \\
\hline Balance of payments, current account surplus & 7.8 & $-3.3^{3)}$ & -1.0 & .. & 3.9 & 11.2 & 6.4 & $0.4^{1)}$ & Bytesbalans överskott \\
\hline Net foreign assets, 31 Dec. 2013 & 40.0 & $17.9^{3)}$ & 46.0 & .. & -422.0 & 134.0 & .. & .. & Utländska tillgångar, netto, 31 dec. 2013 \\
\hline Public balance, surplus & -0.7 & $-1.8^{3)}$ & -2.5 & .. & -3.3 & 13.2 & -1.0 & -3.0 & Offentliga sektorns överskott \\
\hline Public gross debt, 31 Dec. 2013 & 48.6 &.. & 60.7 &.. &.. &.. & 41.7 & 95.2 & Offentliga sektorns skulder, 31 dec. 2013 \\
\hline Per cent & & & & & & & & & Procent \\
\hline Unemployment & 7.0 & 4.4 & 8.2 & 3.5 & 5.4 & 3.5 & 8.0 & 12.0 & Arbetslöshetstal \\
\hline Interest rate & 1.7 & .. & 1.9 & .. & 5.8 & 2.6 & 2.1 & 3.0 & Ränta \\
\hline Per cent change 2012-2013 & & & & & & & & & Procentuell förändring 2012-2013 \\
\hline Inflation rate, consumer prices & 0.5 & -0.6 & 2.2 & 2.3 & 4.1 & 2.0 & 0.4 & 1.4 & Tillväxt $\mathrm{i}$ konsumentpriser \\
\hline Economic growth & 0.4 & .. & -1.4 & .. & 3.3 & 0.6 & 1.6 & -0.4 & Ekonomisk tillväxt \\
\hline Share prices index & 20.0 & .. & 16.4 & .. & 19.6 & 14.0 & 17.1 & .. & Aktiekursindex \\
\hline Effective nominal exchange rate & -3.0 & .. & .. & .. & 2.4 & -3.9 & 1.0 & .. & Effektiv nominell valutakursindex \\
\hline
\end{tabular}

可Key01

Source: Eurostat, OECD, the Danish central bank and national statistical institutes.

auro currency as their sole legal tender. Harmonized unemployment rates for Denmark, Faroe Islands, Finland, Iceland, Norway and Sweden. Interest rate: 10 year government bond yields, average. (in rate: Per cent change from previous year in harmonized indices of consumer prices. ${ }^{1)} 2010^{2)} 2011^{3)} 2012$

Harmoniserat arbetslöshetstal för Danmark, Färöarna, Finland, Island, Norge och Sverige. Ränta: Avkastning på 10-åriga statsobligationer, genomsnitt.

Tillväxt i konsumentpriser: Procentuell förändring i det harmoniserade konsumentprisindexet från förra året. ${ }^{13} 2010^{2)} 2011^{3)} 2012$ 


\section{Economic growth}

Over the past ten years, the Nordic countries had a noticeably larger increase in their gross domestic product (GDP) than the euro area. The only exceptions are Denmark and Åland which had a lower growth. However, from 2007 to 2009, the Nordic countries and the EA17 all had a marked negative growth due to the global financial crisis. Since 2009 most countries have experienced growth again.

Measured by GDP per capita, the Nordic countries have a higher income than the EA17. Norway's GDP per capita is

Gross domestic product at constant prices Bruttonationalprodukten i fasta priser
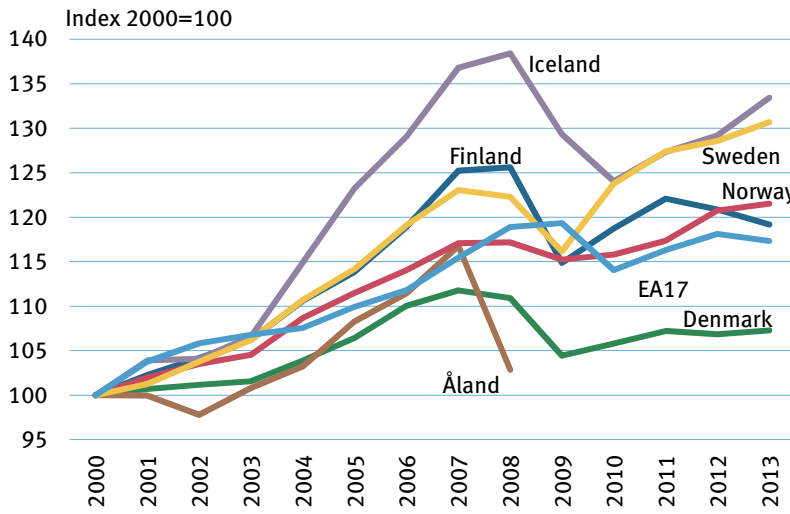

므aac01

Source: Eurostat and national statistical institutes.

the euro as their common currency. as high as 80 per cent above the EA17 average, and Norway is actually one of the countries with the highest standard of living.

Ekonomisk tillvåxt

Under de senaste tio åren har de nordiska länderna haft en markant kraftigare ökning av bruttonationalprodukten (BNP) än euro-länderna. De enda undantagen är Danmark och Åland, som har haft en lägre tillväxt. Från 2007 till 2009 hade de nordiska länderna och EA17 en markant negativ tillväxt till

Gross domestic product, real annual growth Bruttonationalprodukten, årlig realtillväx

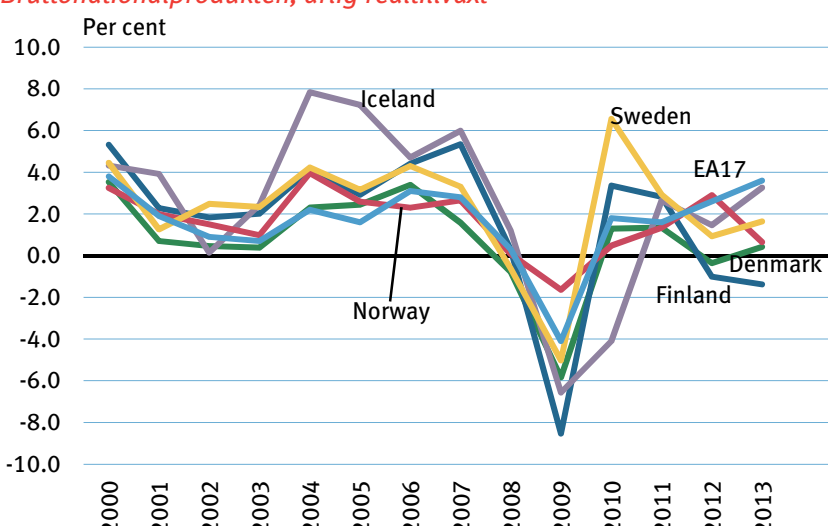

$\square$ NaacO1 and Key01

Source: Eurostat and national statistical institutes.

Not: EA17: De 17 europeiska länderna som har infört euron som gemensam valuta. följd av den världsomspännande ekonomiska krisen. Sedan år 2009 har de flesta länder upplevt tillväxt igen.

De nordiska länderna har en högre inkomst än euro-länderna, mätt med BNP per capita. Norges BNP per capita är så mycket som 80 procent över EA17-genomsnittet, och Norge är faktiskt ett av de länder som har den högsta levnadsstandarden.

Gross domestic product in euro (PPS) per person Figure 11.3 Bruttonationalprodukten per person i euro (PPS)

210 Index EA17=100

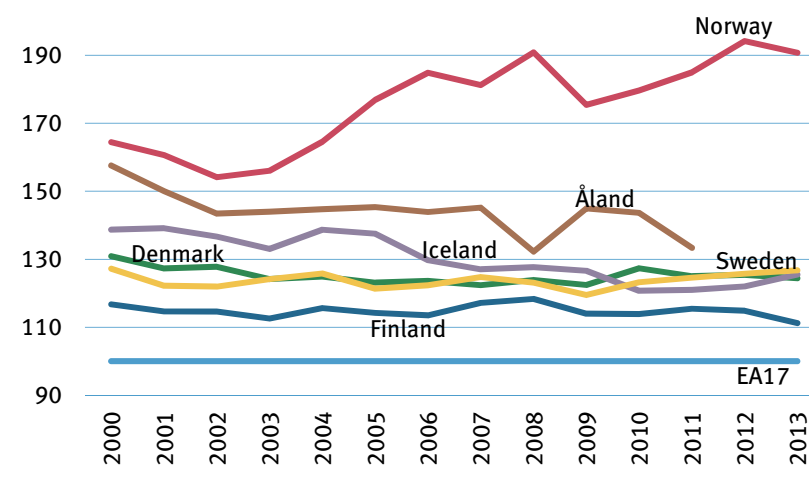

미acos

Source: Eurostat and national statistical institutes.

Note: EA17: The 17 member states that have adopted the euro as their common currency.
PPS: Purch.

countries.
Not: EA17: De 17 europeiska länderna som har infört euron som gemensam valuta.

PPS: Purchasing Power Standards - Köpkraftspariteter som eliminerar skillnader i prisnivà mellan 


\section{Factors behind economic growth}

Private consumption has fallen through the crisis - but has gained pace again since 2009. The decline was most profound in Denmark, Finland and Iceland. Public consumption has, on the other hand, experienced positive growth rates - except for Denmark where consumption has stagnated. The general rise is due to the many fiscal initiatives to support economic growth and the financial and business sectors - and the need to finance higher social expenses because of the crisis.

From 2006 Iceland has experienced a fall in gross capital formation. This is after many years with an Icelandic growth particular

Private consumption at constant prices Figure 11.4 Privat konsumtion i fasta priser

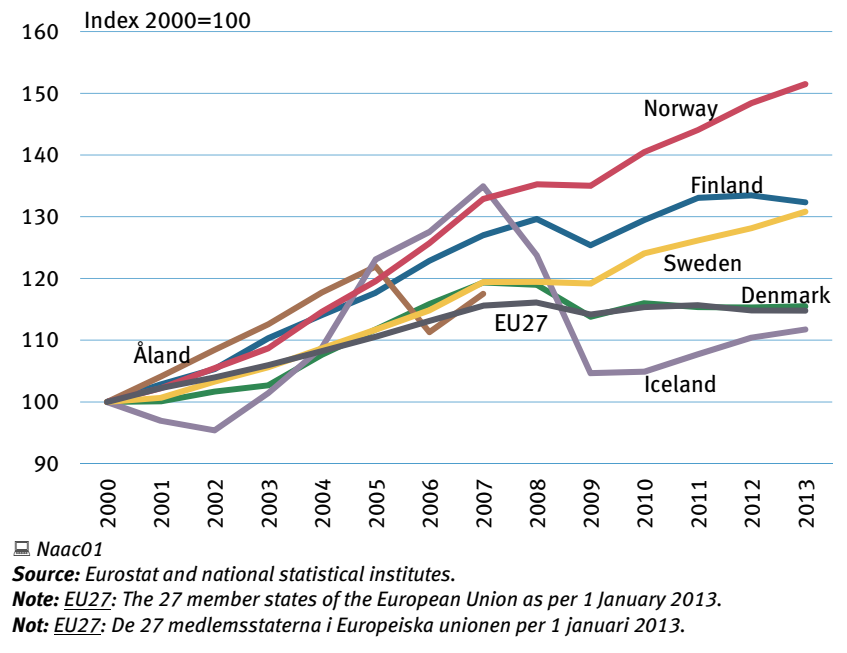

ly driven by investments, which have more than tripled in the recent ten years. Iceland also holds a leading position compared to the other Nordic countries regarding growth in public consumption in the years from 2000 to 2008.

Faktorer bakom den ekonomiska tillvåxten

Den privata konsumtionen har minskat på grund av krisen men har tagit fart igen sedan 2009. Nedgången var djupast $i$ Danmark, Finland och på Island. Den offentliga konsumtionen har däremot haft en positiv tillväxt - utom i Danmark där konsumtionen har stagnerat. Den allmänna ökningen beror på

\section{Public consumption at constant prices} Offentlig konsumtion i fasta priser

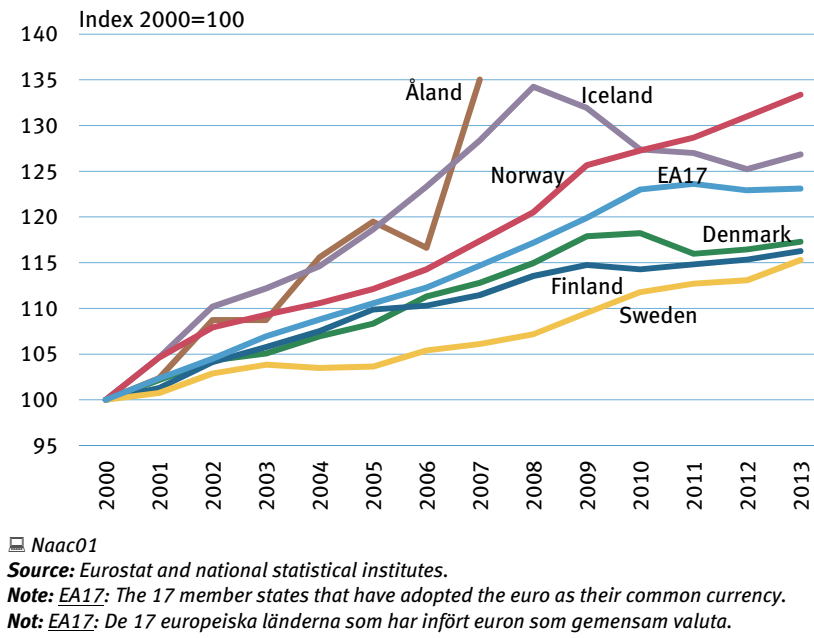

många finanspolitiska initiativ för att stödja den ekonomiska tillväxten samt den finansiella sektorn och näringslivet - och behovet av att finansiera högre sociala utgifter på grund av krisen.

Sedan 2006 har Island upplevt en nedgång i bruttoinvesteringarna. Detta är efter många år med en isländsk tillväxt som har drivits av investeringar, vilka har mer än tredubblats de senaste tio åren. Island har också en ledande position i förhållande till de övriga nordiska länderna när det gäller tillväxt inom offentlig konsumtion under åren 2000 till 2008.

Gross fixed capital formation at constant prices Figure 11.6 Fasta bruttoinvesteringar i fasta prise

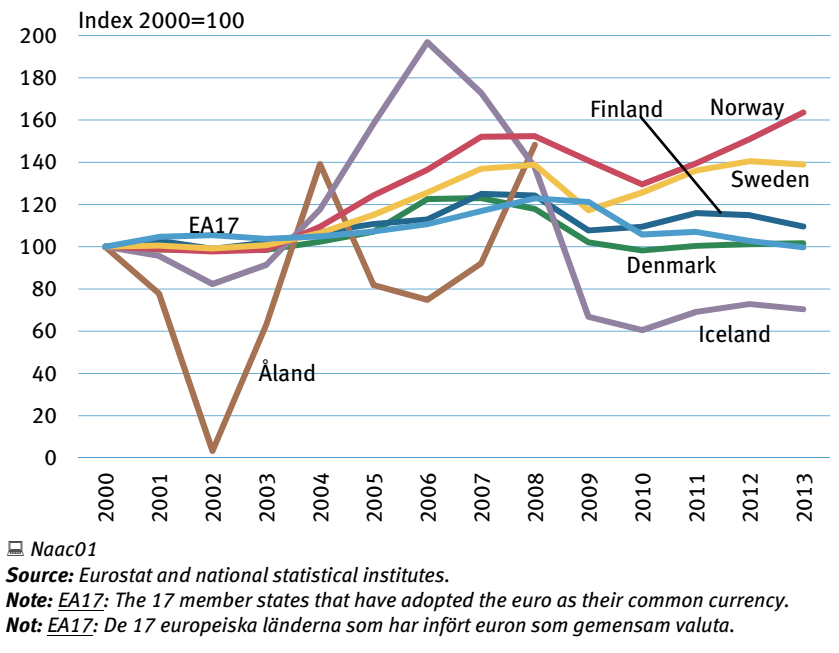




\section{Foreign assets and liabilities}

Recent years' large balance-of-payments surplus in Denmark, Finland, Norway and Sweden has reduced the countries' foreign debt. In addition to a balance-of-payments surplus or deficit, the size of a country's foreign debt and foreign assets is affected by the exchange rate and the price of securities. Consequently, Finland's foreign debt increased noticeably when the price of technology shares increased drastically in the late 1990 s due to a large proportion of these shares being owned by households, funds and companies abroad. In this way, these foreign owners held a greater claim on Finland. When share prices decreased drastically in 1999-2001 especially those of technology shares - it also led to a marked decrease in Finland's net foreign debt.
Iceland's foreign net debt accounts for close to four times of GDP. This means that Iceland (in net terms) owes the surrounding world values corresponding to four times the country's total production. Sweden also had foreign debts by the end of 2010 , however, at a much smaller scale.

\section{Utländska tillgångar och skulder}

Senare års stora överskott i betalningsbalansen i Danmark, Finland, Norge och Sverige har minskat ländernas skuld till utlandet. Förutom över- eller underskott i betalningsbalansen påverkas storleken av ett lands utlandsskuld och utländska tillgångar av kurserna på valuta och värdepapper. Därför ökade Finlands utlandsskuld markant när kurserna på IT-aktier steg
Foreign assets and liabilities. End of 2013 Utländska tillgångar och skulder

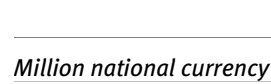
Per cent of GDP

Net assets 736

21
18
3

627
596
30

$$
\begin{array}{r}
4698 \\
12230
\end{array}
$$$$
\begin{array}{r}
12230 \\
-7532
\end{array}
$$

46
Table 11.2

Source: Bank of Finland, Central Bank of Iceland and national statistical institutes. Note: Faroe Islands: 2012 data. våldsamt i slutet på 90-talet, eftersom en stor del av dessa aktier ägdes av hushåll, fonder och företag i utlandet. De utländska ägarna fick därmed ett större krav på Finland. När aktiekurserna 1999-2001 sjönk drastiskt - särskilt kurserna på IT-aktier - medförde det på samma sätt en markant nedgång i Finlands nettoskuld till omvärlden.

Islands utländska nettoskuld står för nära fyra gånger BNP. Detta innebär att Islands nettoskuld till omvärlden motsvarar fyra gånger landets totala produktion. Sverige hade också utländska skulder i slutet av 2010, men i mycket mindre skala.

Net foreign assets by end of year Figure 11.7 Utländska tillgångar netto vid årets slut

200
100 Per cent of GDP

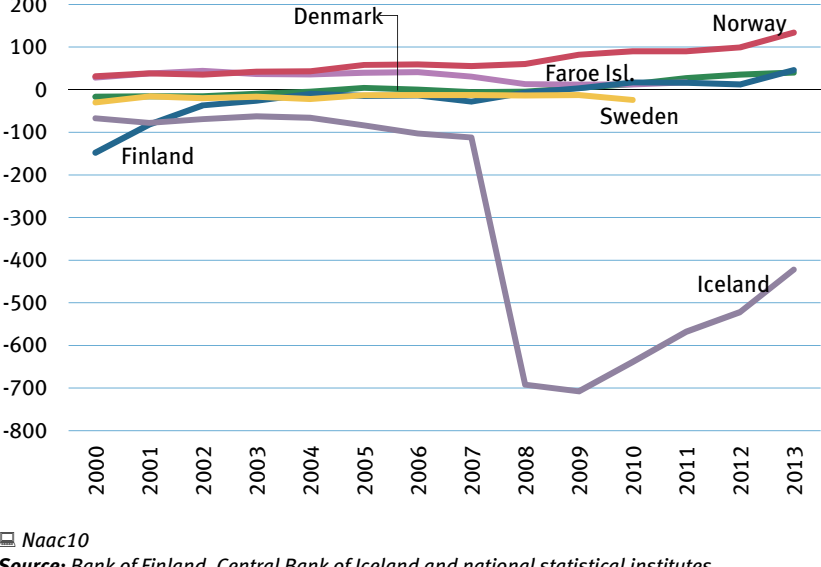

Source: Bank of Finland, Central Bank of Iceland and national statistical institutes. 


\section{Balance of payments}

The balance of payments is a statement of the values of economic transactions between the domestic economy and the rest of the world. Exports and imports of goods are the largest items of the revenue and expenditure accounts of the balance of payments. In 2013, all Nordic countries, besides Finland, had a surplus on the total balance of payments (current account, total). Norway accounts for a substantial foreign exchange surplus, which is due to revenue from exports of oil and gas.

\section{Betalningsbalans}

Betalningsbalansen är en redovisning av ett lands ekonomiska utbyte med utlandet. Exporten och importen av varor utgör de största posterna på intäkts- respektive utgiftssidan av betalningsbalansen. Under 2013 hade alla de nordiska länderna, utom Finland, överskott i den sammanlagda betalningsbalansen (bytesbalansen). Det norska valutaöverskottet är extremt stort på grund av landets intäkter genom export av olja och gas.
Denmark Faroe Islands

Finland

Iceland

Norway

Sweden

EA17

Per cent of GDP
2000
2005
2006
2007
2008
2009
2010
2011
2012
2013

2013

$\begin{array}{lc}.4 & 9.4 \\ 4.5 & 1.8 \\ .0 & 1.1 \\ .4 & -3.5 \\ .0 & -1.3 \\ .3 & -1.1 \\ 5.7 & 6.3 \\ 6.5 & 6.7 \\ 5.2 & -3.3 \\ 7.8 & \end{array}$

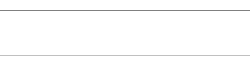

15.0

9.4
1.8
.1
-.5
-3
.1
.1
.3
.7
-3.3
..

$\begin{array}{rr}8.1 & -10.2 \\ 3.4 & -16.0 \\ 4.3 & -23.8 \\ 4.4 & -16.4 \\ 2.7 & -24.5 \\ 1.8 & -10.3 \\ 1.4 & -7.8 \\ -1.2 & -7.1 \\ -1.4 & -5.5 \\ -1.0 & 3.9\end{array}$

$\begin{array}{rl}-10.2 & 15.0 \\ -16.0 & 17.7 \\ -23.8 & 18.7 \\ -16.4 & 13.0 \\ -24.5 & 17.8 \\ -10.3 & 11.3 \\ -7.8 & 13.9 \\ -7.1 & 16.4 \\ -5.5 & 14.3 \\ 3.9 & 11.2\end{array}$

$\begin{array}{lll}15.0 & 4.0 & -0.7 \\ 17.7 & 6.8 & -0.4 \\ 18.7 & 8.6 & -1.2 \\ 13.0 & 9.5 & 0.1 \\ 17.8 & 9.1 & -1.6 \\ 11.3 & 7.2 & -0.3 \\ 13.9 & 7.0 & -0.4 \\ 16.4 & 7.1 & \\ 14.3 & 7.2 & \\ 11.2 & 6.4 & \\ \end{array}$

Procentav $B N P$

\begin{tabular}{rr}
-0.7 & 2000 \\
-0.4 & 2005 \\
-1.2 & 2006 \\
0.1 & 2007 \\
-1.6 & 2008 \\
-0.3 & 2009 \\
-0.4 & 2010 \\
.. & 2011 \\
.. & 2012 \\
.. & 2013 \\
\hline
\end{tabular}

Eustat, Bank of Finland, Central Bank of Iceland, the Swedish Central Bank and national statistical institutes. 


\section{Foreign direct investment}

Iceland and Sweden have the highest rate of foreign direct investment, both with regards to foreign companies investing in Iceland and Sweden and Icelandic and Swedish companies investing abroad. However, Denmark was at the same level as Iceland in 2012 regarding outward investments. Looking at a larger time span of ten years most of the Nordic countries have experienced growth in both inward and outward investments.

Iceland has been in a league of its own in this area. Foreign investment from Iceland increased significantly and sharply especially from 2003 to 2007 , from 16 to 123 per cent of GDP. The expansion of Icelandic companies into foreign markets was a rapid process. Strong pension funds provided capital for investments, and the privatization of the banking system made new sources of financing available for companies wishing to expand their operations. Also inward investment to Iceland increased from 2003, but at a more moderate level compared with other Nordic countries. This pattern changed in 2007 with dramatic decreases in both outward and inward foreign direct investment.
Utländska direktinvesteringar

Island och Sverige har den högsta andelen utländska direktinvesteringar, såväl genom att utländska företag investerar i Island och Sverige som att isländska och svenska företag investerar utomlands. Men 2012 låg Danmark på samma nivå som Island när det gäller investeringar utåt. När man tittar på en längre tidsperiod över tio år har de flesta nordiska länderna haft en tillväxt i utländska direktinvesteringar, både inåt och utåt.

Island är i en klass för sig på detta område. Utländska investeringar från Island ökade avsevärt, särskilt från 2003 till 2007 då investeringarna ökade från 16 till 123 procent av BNP. Utbygg naden av isländska företag till utländska marknader var en snabb process. Starka pensionsfonder som kapital för investeringar och privatiseringen av banksystemet gav nya finansieringsmöjligheter för företag som ville expandera sin verksamhet. Även utländska investeringar på Island ökade från 2003, men på en mer måttlig nivå jämfört med de andra nordiska länderna. Detta mönster ändrades under 2007 med dramatiska minskningar av utländska direktinvesteringar både från utlandet och till utlandet.

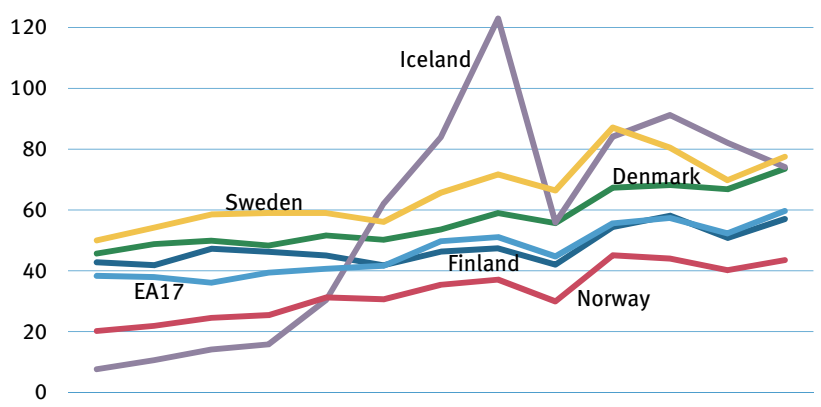

2000200120022003200420052006200720082009201020112012

100 Inward investment - per cent of GDP

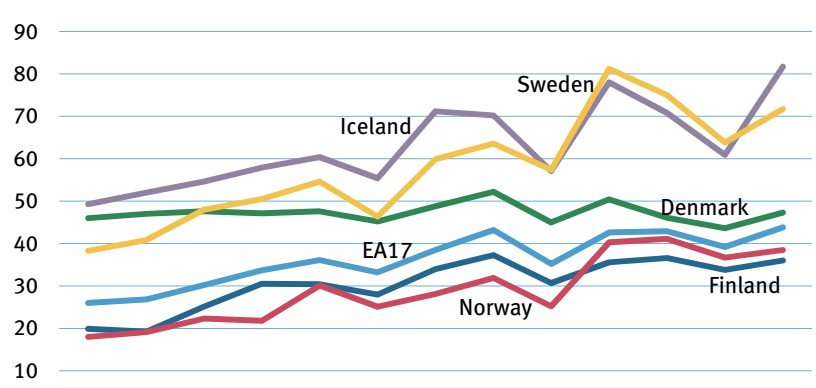




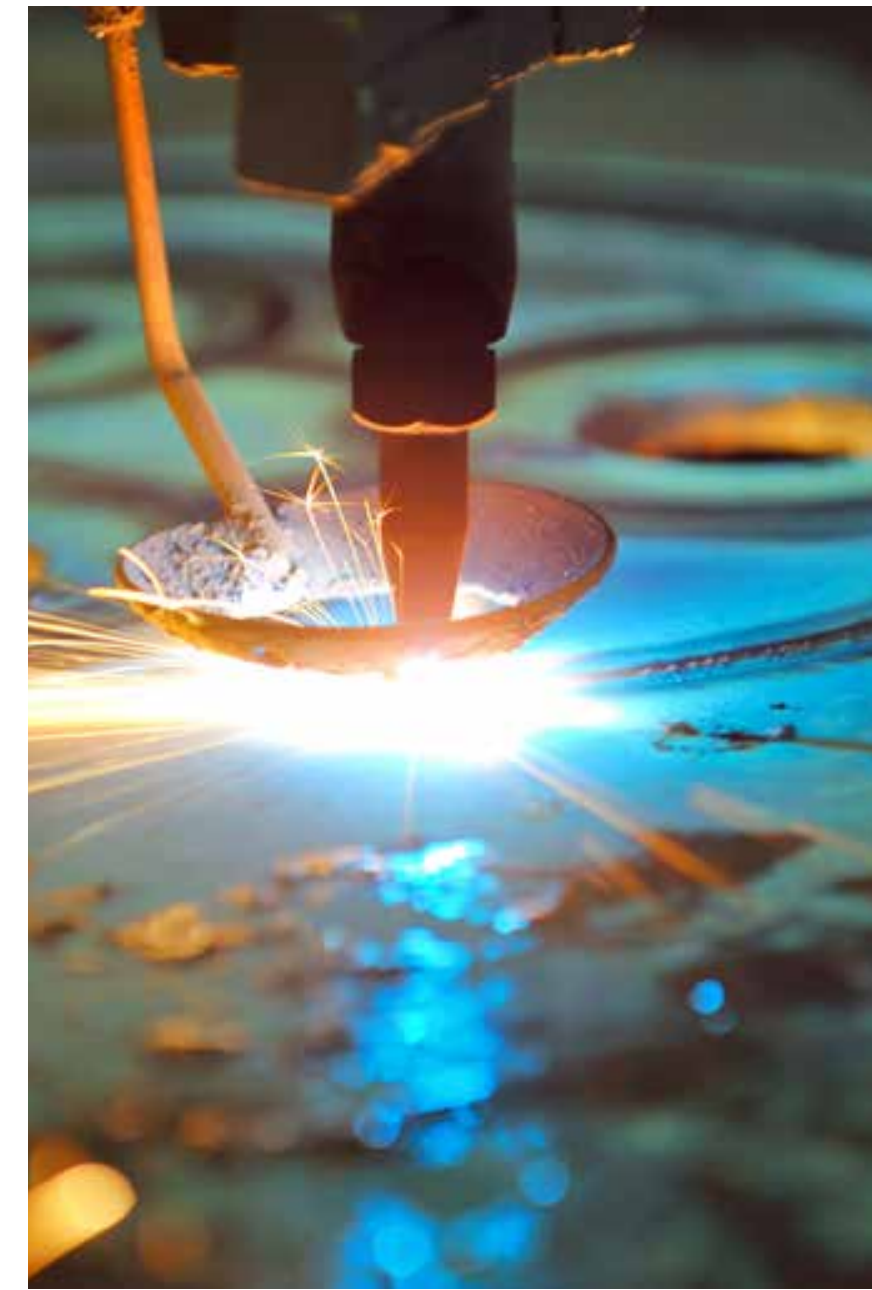

Foto: SignElements
Manufacturing's proportion of the economy

Since the late 1990s, the Nordic manufacturing industry has accounted for a slightly declining proportion of the gross domestic product, with Norway as a distinct exception. Here, the manufacturing industry's proportion of GDP is still at a high level of around 35 per cent due to the large oil and natural gas sector. In the rest of the Nordic countries, the proportion lies between 17 and 19 per cent.

Despite growing production, the manufacturing industry accounts for a decreasing proportion of total employment in the Nordic coun tries. Among the Nordic countries, Finland is today the number one Nordic industrial country, as the manufacturing industry in Finland accounts for the greatest proportion of the country's jobs, i.e. 16 per cent. By way of comparison, in Denmark, Norway and Iceland it only accounts for around 12 per cent of total employment.

Industrins andel av bruttonationalprodukten Sedan slutet på 1990-talet har industrin i Norden stått för en svagt vikande andel av bruttonationalprodukten med Norge som ett markant undantag. Där ligger industrins andel av BNP fortfarande på en hög nivå, ungefär 35 procent, på grund av den stora olje- och gasproduktionen. I resten av de nordiska länderna ligger andelen mellan 17 och 19 procent.

Trots ökande produktion utgör industrin en sjunkande andel av den totala sysselsättningen i de nordiska länderna. Finland är i dag Nordens industriland nummer ett såtillvida att industrins andel av arbetsplatserna är högst i Finland, nämligen 16 procent. Som jämförelse står industrin i Danmark, Norge och på Island för kring 12 procent av den totala sysselsättningen.
45 Per cent of total gross value

40

35

30

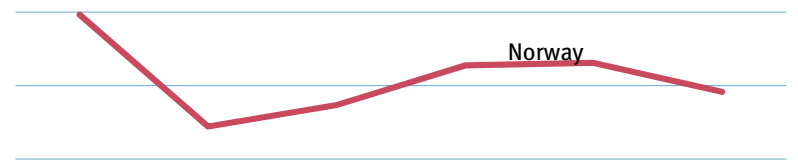

20 Sweden

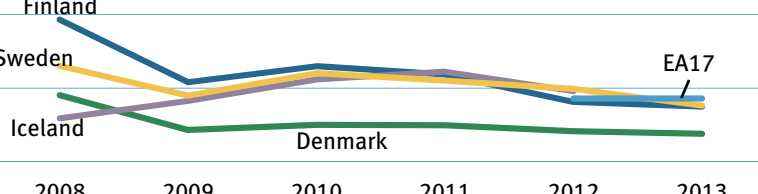

2008

2009

2010

20 Per cent of total employment

19

$18 \longrightarrow$ EA17

17

16

$(6$

15

14

12

11

10

EA17
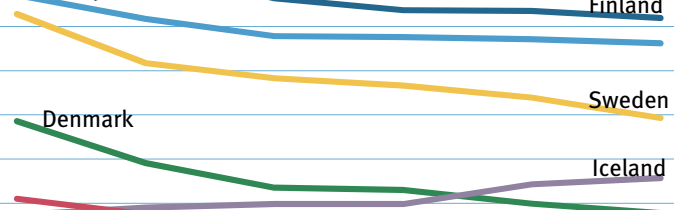

Norway

2008

2009

2010

2011

2012

2013

$\square \mathrm{NaaC0} 5$ and $\mathrm{NaaCO} 8$

Source: Eurostat and national statistical institutes.

ed the euro as their common currenc. Not: EA17: De 17 europeiska länderna som har infört euron som gemensam valuta. 


\section{The service sector's proportion of the economy}

The service sector has increased drastically in all Nordic countries in the last 15 years and today accounts for about three fourths of all employed persons. Denmark has the largest proportion of employed in the service sector, around 80 per cent of those employed. Iceland and Norway have the lowest proportion with around 70 per cent.

The service sector has almost the same size if the proportion of total gross domestic product is measured compared to the share of employment. In Denmark, the service sector accounts for almost 82 per cent of GDP. In Norway, where the proportion is the lowest, the service sector accounts for 64 per cent.

The service sector includes retail and wholesale trade, hotels, restaurants, transportation, communication, financial services, real estate sale, renting, business services and other services such as teaching and care of children, sick persons and the elderly - services typically rendered by the public sector in the Nordic countries.
Servicesektorns andel av bruttonationalprodukten Servicesektorn har växt markant i alla de nordiska länderna under de senaste 15 åren och står i dag för cirka tre fjärdedelar av all sysselsättning i Norden. Danmark har den största andelen sysselsatta inom servicesektorn, nämligen ca 80 procent. Island och Norge har den lägsta andelen med kring 70 procent.

Servicesektorns andel av den totala bruttonationalprodukten är i ungefär samma storleksordning som dess andel av sysselsättningen. I Danmark svarar servicesektorn för nästan 82 procent av BNP. I Norge, som har den lägsta andelen, ligger procenten kring 64 procent.

Servicesektorn omfattar detalj- och grossisthandel, hotell, restauranger, transport, kommunikation, finansiella tjänster, fastighetsmäklarverksamhet, uthyrning, affärsverksamhet samt övriga tjänster som t.ex. undervisning och vård av barn, sjuka och gamla - tjänster som den offentliga sektorn vanligen tar hand om i de nordiska länderna.
80 Per cent of total gross value

Denmark

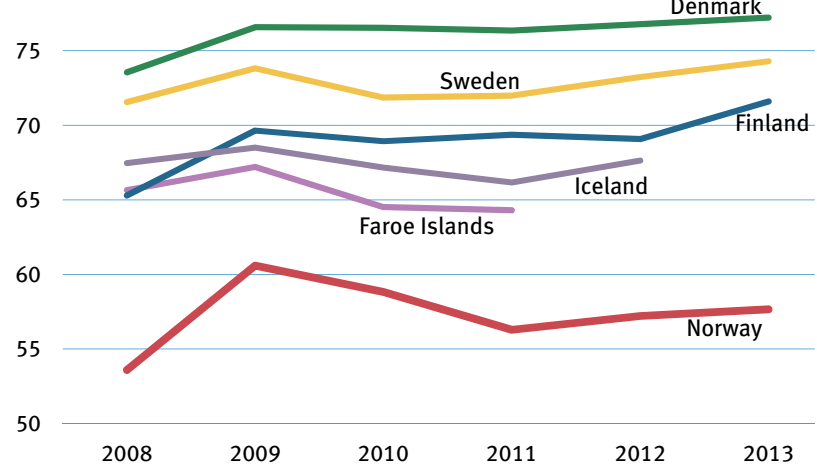

81 Per cent of total employment

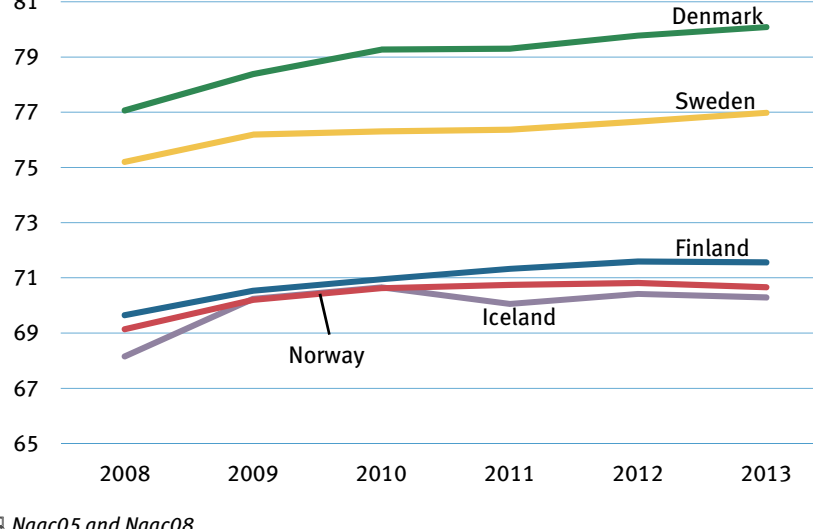

Naac05 and $\mathrm{NaaCO}$

Source: Eurostat and national statistical institutes. 


\section{Foreign trade Utrikeshandel}

Nordic cooperation is characterized largely by the international community and the global challenges and opportunities. The Nordic countries, which are relatively small, can benefit greatly by obtaining common use in cooperation with other countries and institutions.

\section{Small, open economies}

The Nordic countries are small, open economies and thus export-depending countries. Foreign trade constitutes an important part of the economic activity. Nordic foreign trade in goods, measured as the average of imports and exports, amounts to more than one fourth of GDP in the Nordic countries.

All the Nordic countries, except the Faroe Islands, Greenland and Finland, have a surplus in their balance of trade in 2013. Every year since 1995 Denmark, Norway and Sweden have all had greater exports than imports.
Det nordiska samarbetet präglas till stor del av det internationella samhället och de globala utmaningarna och möjligheterna. De nordiska länderna, som är relativt små, kan vinna mycket på en gemensam användning i samarbete med andra länder och institutioner.

\section{Små och öppna ekonomier}

De nordiska länderna är små och därmed exportberoende länder. Utrikeshandeln är en viktig del av den ekonomiska verksamheten. Utrikesvaruhandeln, uttryckt som ett medelvärde av import och export, uppgår till mer än en fjärdedel av de nordiska ländernas BNP.

Alla nordiska länder utom Färöarna, Grönland och Finland hade ett överskott i sin handelsbalans 2013. Sedan 1995 har Danmark, Norge och Sverige varje år haft en större export än import.

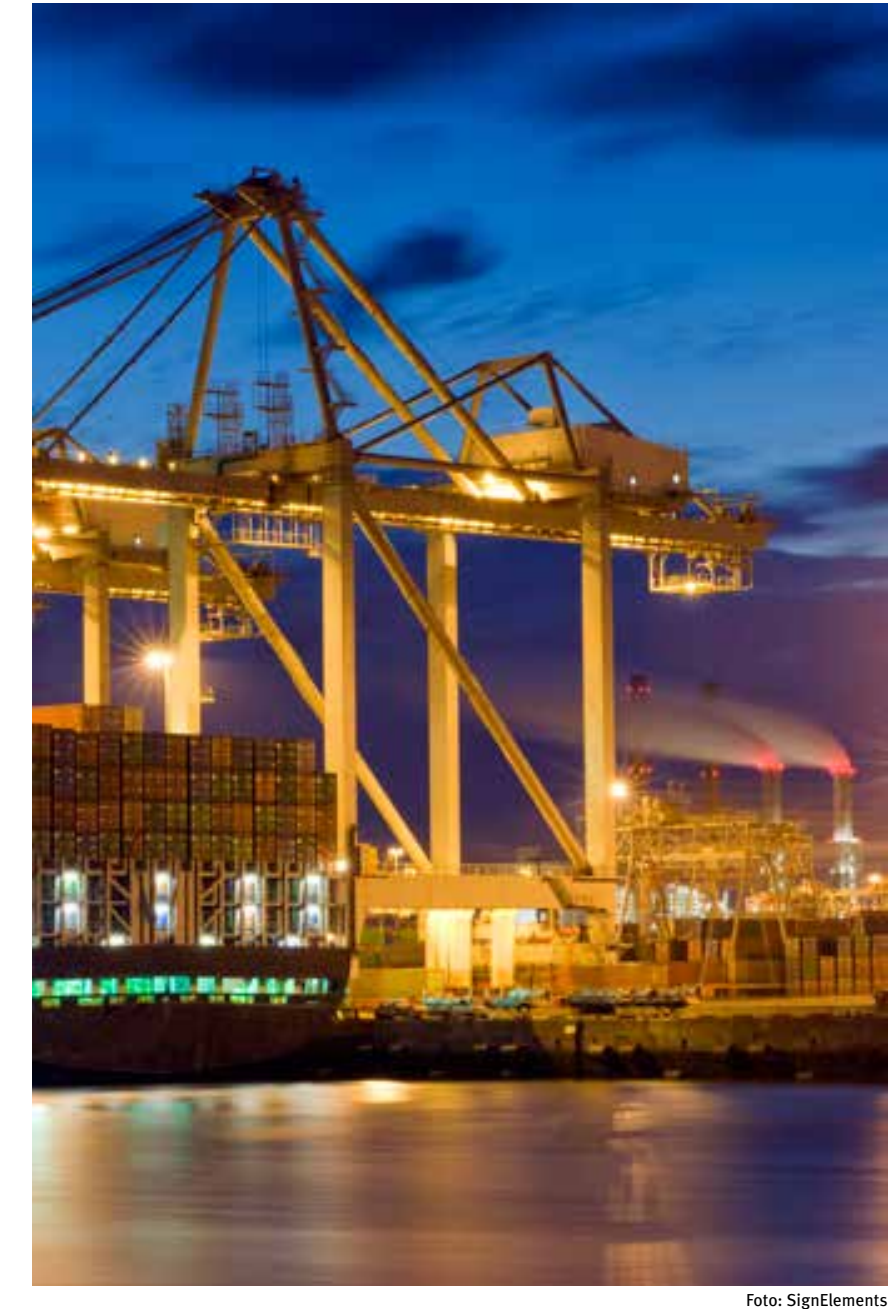

Foto: SignElements 

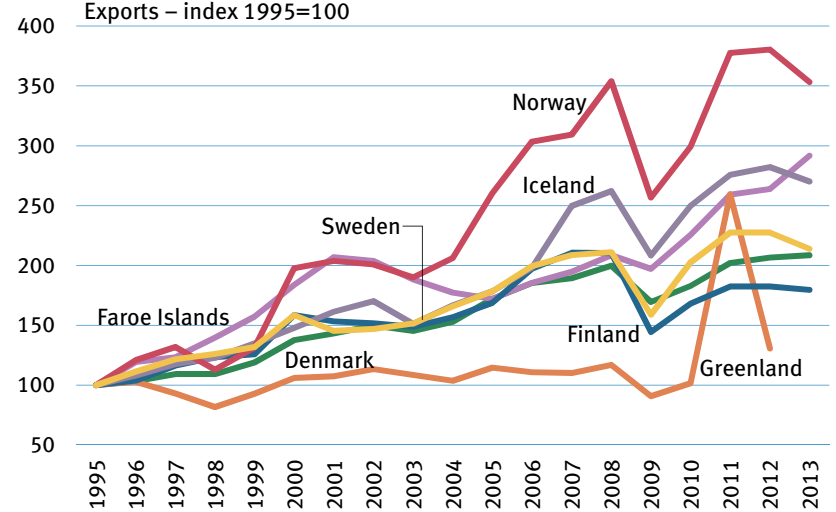

400 Imports - index $1995=100$

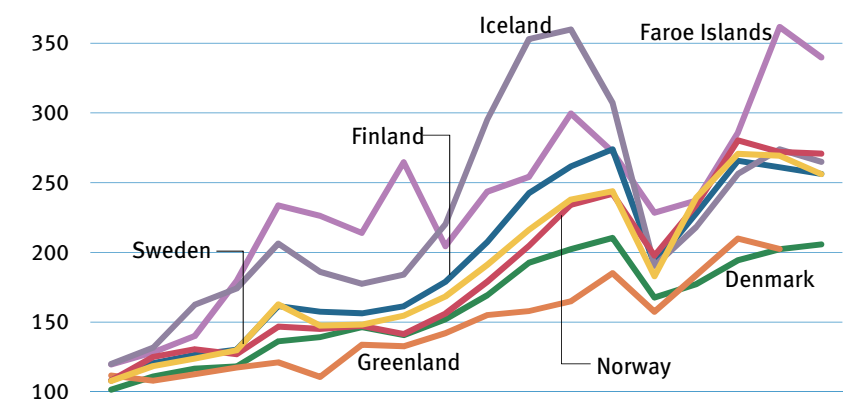

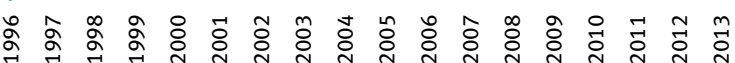
마 Fotr 43 and Fotr 44

E

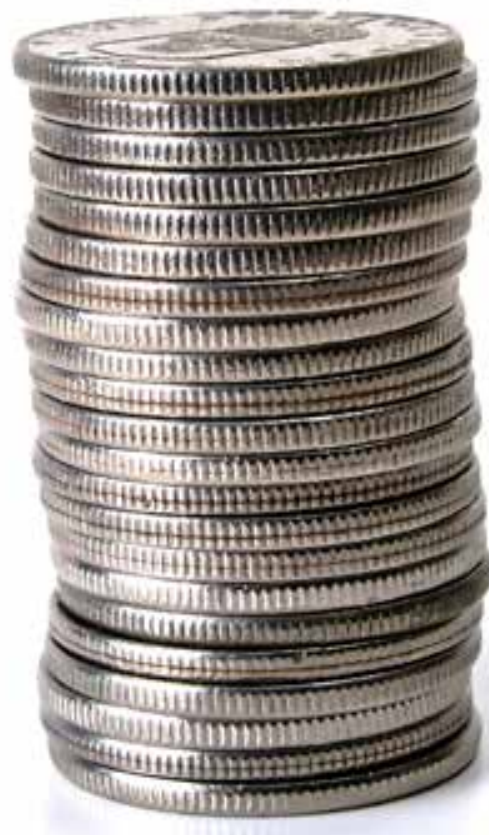

40 Per cent of GDP

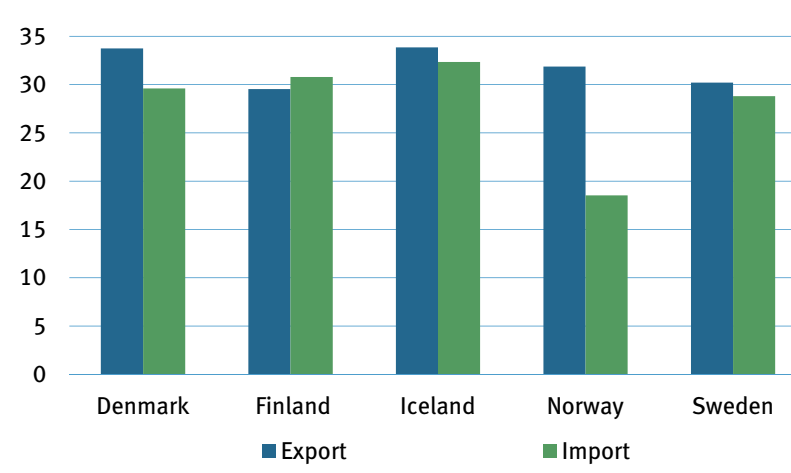

D. Naac01, Fotr44 and Fotr 43

Source: National statistical institutes and Eurostat. 
Handelsbalans för varor i procent av BNP

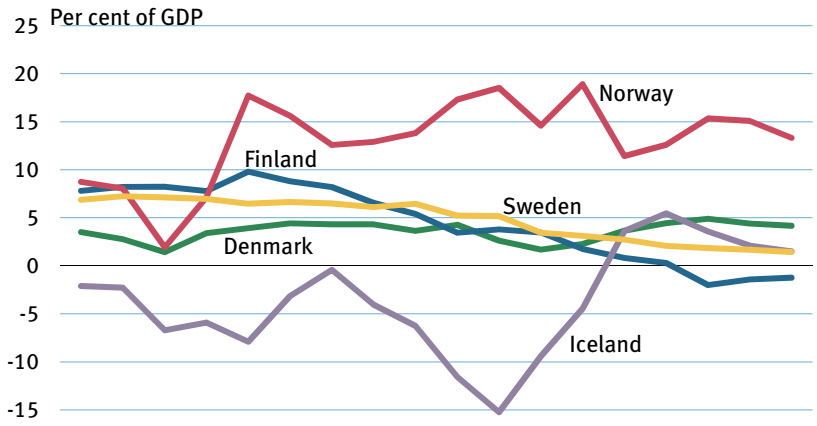

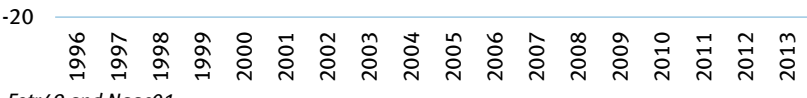

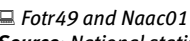

cal institutes and Eurostat.
Handelsbalans för varor

\begin{tabular}{|c|c|c|c|c|c|c|c|c|}
\hline & Denmark & Faroe Islands & Greenland & Finland & Iceland & Norway & Sweden & \\
\hline Million euro & & & & & & & & Miljoner euro \\
\hline 1990 & & & & & & & & 1990 \\
\hline Exports & 28973 & 327 & 355 & 20832 & 1247 & 26560 & 45192 & Export \\
\hline Imports & 26023 & 265 & 327 & 21181 & 1301 & 21341 & 43067 & Import \\
\hline Net exports & 2951 & 63 & 27 & -349 & -54 & 5220 & 2125 & Nettoexport \\
\hline 2013 & & & & & & & & 2013 \\
\hline Exports & 82959 & 816 & 371 & 56034 & 3762 & 116200 & 126274 & Export \\
\hline Imports & 72743 & 841 & 671 & 58391 & 3599 & 67616 & 120337 & Import \\
\hline Net exports & 10216 & -25 & -300 & -2357 & 163 & 48584 & 5937 & Nettoexport \\
\hline
\end{tabular}

Source: National statistical institutes and Eurostat.

Note: Greenland: 2012 data.

Not: Gröland: 2012 års uppgifter.

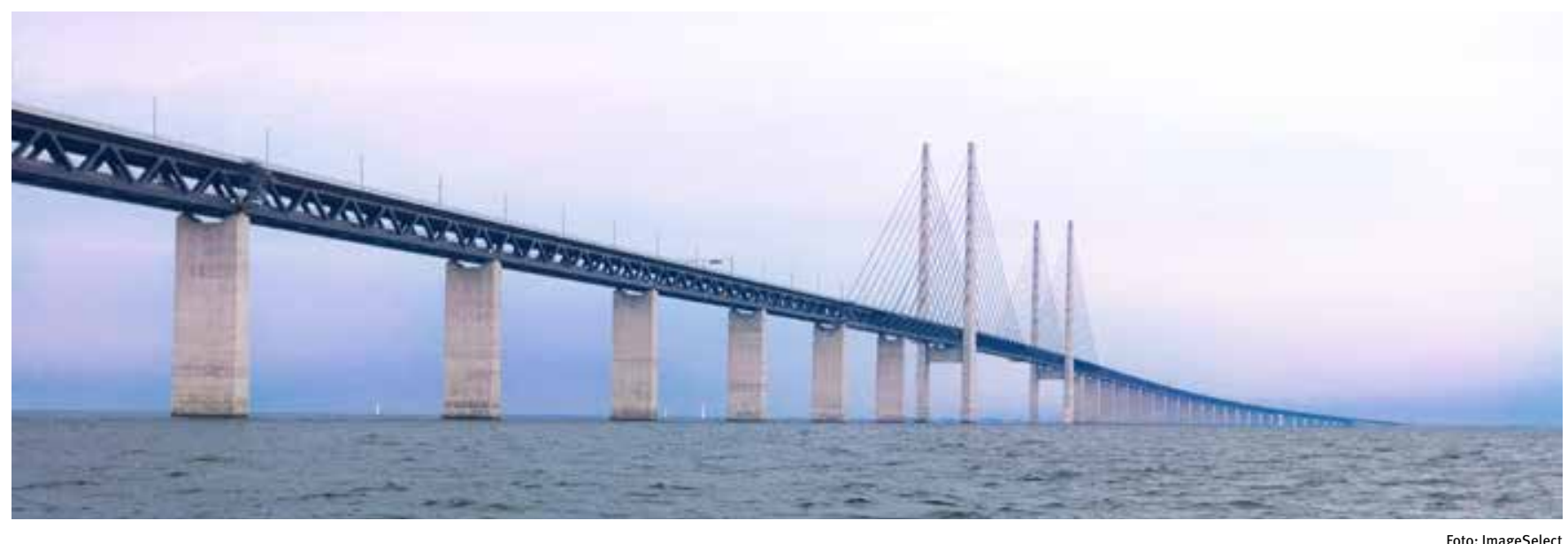




\section{Intra-Nordic trade}

The trade between the Nordic countries is quite considerable. About one fifth of the countries' foreign trade is trade with other Nordic countries. The total population of the Nordic countries of 26 million people makes them to a far greater extent dependent on each other with respect to exports and imports, compared to for example Germany with a population of 81 million people. Swedish exports to the other Nordic countries account for a considerably higher share than combined Swedish exports to Germany and France - despite the fact that the total population of Germany and France is 147 million people, while Denmark, Finland, Iceland and Norway only have a total population of 16.5 million.

In 2013, between 23 and 25 per cent of the total exports from both Denmark and Sweden went to other Nordic countries. Other Nordic countries account for 16 per cent of Finnish exports, 11 per cent of Norwegian exports and 10 per cent of the total exports in Iceland.
Inomnordisk handel

Den inomnordiska handeln är tämligen omfattande. Ungefär en femtedel av utrikeshandeln sker med andra nordiska länder. De nordiska länderna med tillsammans 26 miljoner invånare är export- och importmässigt mer beroende av varandra än t.ex. av Tyskland med 81 miljoner invånare. Sveriges export till övriga Norden är väsentligt större än den svenska exporten till Tyskland och Frankrike tillsammans trots att den sammanlagda folkmängden i Tyskland och Frankrike är hela 147 miljoner, medan summan av invånarantalet i Danmark, Finland, Island och Norge endast uppgår till 16,5 miljoner.

År 2013 gick mellom 23 och 25 procent av både Danmarks och Sveriges samlade export till andra nordiska länder. För Finlands del uppgår exporten till det övriga Norden till 16 procent, för Norges del till 11 procent, och för Islands del till 10 procent av den totala exporten.
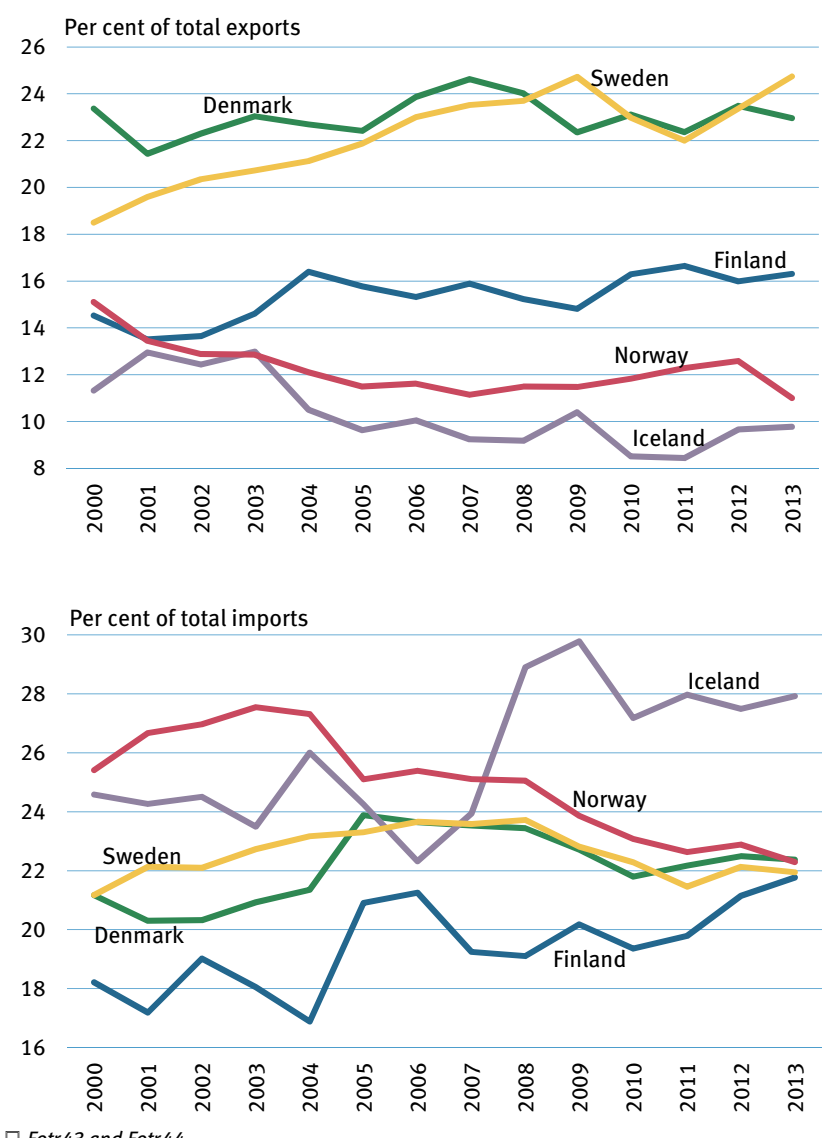


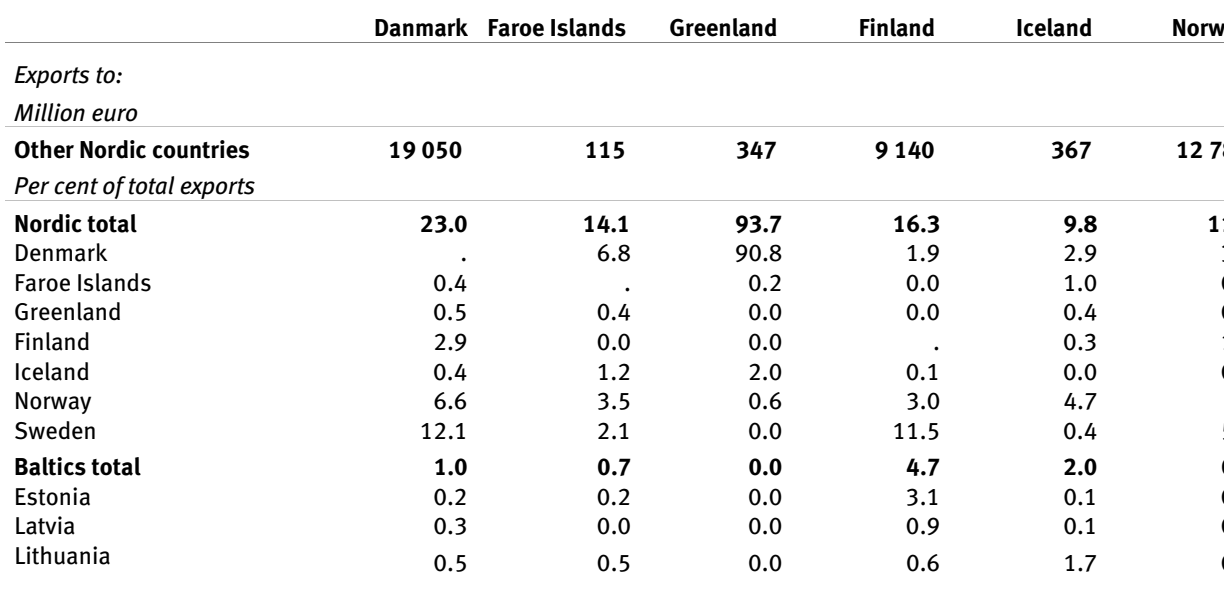

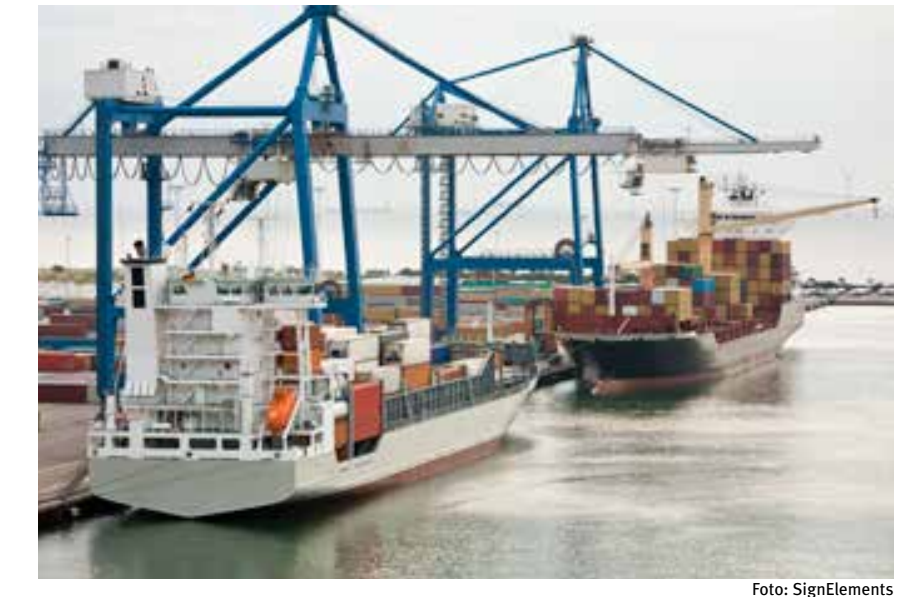

Imports from

Million euro

Other Nordic countries

Per cent of total imports

$16276 \quad 526$

579

12711

21.8
3.1
0.0
0.0
0.0
3.3
14.7
3.7
2.8
0.5
0.4

$\begin{array}{rrrr}\mathbf{2 1 1} & \mathbf{1 0 0 3} & \mathbf{1 5 0 7 6} & \mathbf{2 6 4 0 7} \\ \mathbf{2 1 . 8} & \mathbf{2 7 . 9} & \mathbf{2 2 . 3} & \mathbf{2 1 . 9} \\ 3.1 & 5.6 & 6.2 & 8.4 \\ 0.0 & 0.2 & 0.1 & 0.0 \\ 0.0 & 0.2 & 0.0 & 0.0 \\ 0.0 & 0.9 & 2.8 & 5.0 \\ 0.0 & . . & 0.3 & 0.0 \\ 3.3 & 16.6 & 13.5 & 8.7 \\ 14.7 & 3.8 & 2.0 & \\ \mathbf{3 . 7} & \mathbf{1 . 5} & \mathbf{2 . 0} & \mathbf{2 . 3} \\ 2.8 & 0.6 & 0.7 & 1.4 \\ 0.5 & 0.4 & 0.6 & 0.4 \\ 0.4 & 0.5 & 0.8 & 0.6\end{array}$

Nordic total

Faroe Island

Greenland

Finland

Iceland

Sweden

Baltics total

Estonia

Lithuania

$\begin{array}{rrr}\mathbf{2 2 . 4} & \mathbf{6 2 . 6} & \mathbf{8 6 . 3} \\ . . & 24.6 & 59.3 \\ 0.3 & . & 0.2 \\ 0.5 & 0.5 & 0.1 \\ 1.7 & 0.6 & 0.1 \\ 0.2 & 4.4 & 1.4 \\ 6.6 & 28.7 & 3.8 \\ 13.3 & 3.8 & 21.5 \\ 1.5 & \mathbf{1 . 1} & \mathbf{0 . 1} \\ 0.3 & 0.3 & 0.0 \\ 0.5 & 0.2 & 0.0 \\ 0.6 & 0.7 & 0.1\end{array}$

Fotr 49

Source: National statistical institutes.

Note: Greenland: 2012 data.

26407

24.7

Sweden

vriga nordiska länd Procent av total export

Norden tota

Danmark

Färöarn

Grönland

Sverige

Baltikum

Estlan

Lettland

Litauen

Import från:

Miljoner euro

Övriga nordiska länder Procent av total import

Norden totalt Danmark Färöarna

Grönland

Finland

Island
Norge

Sverig

Baltikum totalt

Estland
Lettland

Litauen
Did you know that ... in 1960 Germany was the most important trading partner for all the Nordic countries when it comes to imports and United Kingdom was in second place. This is still the case, but now with the Netherlands in second place closely followed by China and Russia.

Visste du att ... 1960 var Tyskland den viktigaste handels partnern för alla de nordiska länderna när det gäller import och Storbritannien kom på andra plats. Detta är fortfarande fallet, men nu med Holland på andra plats tätt följt av Kina och Ryssland. 
Denmark

$$
\begin{array}{r}
\text { Faroe } \\
\text { Islands }
\end{array}
$$

Greenland

Sweden

\section{Percent}

Exports to:

Total

Nordic countries

EU27 (excl. DK. Fl. SE)

Other Europe

USA and Canada

Other America

Japan

DAES

Rest of the world
Rceania

Imports from:

Nordic countries

EU27 (excl. DK. Fl. SE)

Other Europe

OSA and Canada

BRIC countries

Japan
DAEs

DAES

Rest of the world

Dotr49

Source: National statistical institutes and Eurostot

Note: Greenland: 2012 data. BRIC countries: Brazil. Russia. India and China. DAEs (Dynamic Asian Economies): Hong Kong. Malaysia. Singapore. South Korea. Taiwan and Thailand. Oceania: Australia and Other Oceania. Not: Grölland: 2012 års uppgifter. BRIC-läde
Oceanien: Australien och övriga Oceanien.
Procent Export till:

$\begin{array}{rrr}\mathbf{0 0 . 0} & \mathbf{1 0 0 . 0} & \mathbf{1 0 0} .0 \\ 14.1 & 93.7 & 16.3 \\ \mathbf{4 2 . 3} & 3.2 & 41.6 \\ 0.9 & 2.6 & 3.5 \\ 11.2 & 0.6 & 7.7 \\ 0.9 & 0.0 & 1.9 \\ 18.2 & 0.0 & 16.2 \\ 0.9 & 0.0 & 1.8 \\ 1.8 & 0.0 & 3.7 \\ 0.0 & 0.0 & 1.0 \\ 9.7 & 0.0 & 6.3\end{array}$

$\mathbf{1 0 0 . 0}$
16.3
41.6
3.5
7.7
1.9
16.2
1.8
3.7
1.0
6.3

100.0

9.8

70.7

2.9
5.4

0.6

4.6
1.9

$\begin{array}{rr} & \\ \mathbf{1 0 0 . 0} & \mathbf{1 0 0 . 0} \\ 11.0 & 24.7 \\ 71.3 & 43.5 \\ 1.5 & 3.1 \\ 5.4 & 6.9 \\ 0.5 & 1.4 \\ 3.5 & 7.6 \\ 0.8 & 1.3 \\ 3.8 & 2.8 \\ 0.3 & 1.3 \\ 2.1 & 7.3\end{array}$

$\begin{array}{rr}\mathbf{1 0 0 . 0} & \mathbf{1 0 0} \\ 23.0 & \\ 48.0 & \\ 2.4 & \\ 7.0 & \\ 1.5 & \\ 6.5 & \\ 1.8 & \\ 3.7 & \\ 1.1 & \\ 5.0 & \\ & \end{array}$

$\begin{array}{rr}100.0 & 100 . \\ 22.4 & 62.6 \\ 55.8 & 26.2 \\ 2.1 & \\ 2.6 & \end{array}$

\section{$100.0 \quad 100.0 \quad 100.0$}

100.0
21.8
46.2
1.3

\section{0}

\subsection{3}

22.3
42.8
2.9

$\begin{array}{rr}33.9 & 42.8 \\ 2.5 & 2.9 \\ 11.0 & 7.7\end{array}$

$2.5 \quad 2.7$

$1.0 \quad 0.4$

$\begin{array}{lll}9.4 & 6.2 \\ 0.4 & 0.8\end{array}$

$\begin{array}{ll}0.4 & 0.8 \\ 2.5 & 0.8 \\ 0.2 & 0.5\end{array}$

$\begin{array}{ll}2.5 & 0.8 \\ 0.2 & 0.5 \\ 3.7 & 0.7\end{array}$

3.1
0.7

22.3

0.5

$\begin{array}{ll}0.7 & 0.5 \\ 0.2 & 0.2\end{array}$

$0.7 \quad 2.6$

2.0

17.3

1.5
2.2
0.1

0.1

1.1
12.9
2.2

0.2

100.0

100.0

EU27 (exkl. DK. H. SE)

EU27 (exkl. DK. Fl. SE)

Övriga Europa

Övriga Amerika

Ovriga Amerika
BRIC-länderna

BRIC-lannderna
Japan

DAE-länderna

Oceanien
Övriga världen

$\begin{array}{rr}\mathbf{1 0 0 . 0} & \mathbf{1 0 0 . 0} \\ 86.3 & 21.8 \\ 5.4 & 46.2 \\ 0.8 & \end{array}$

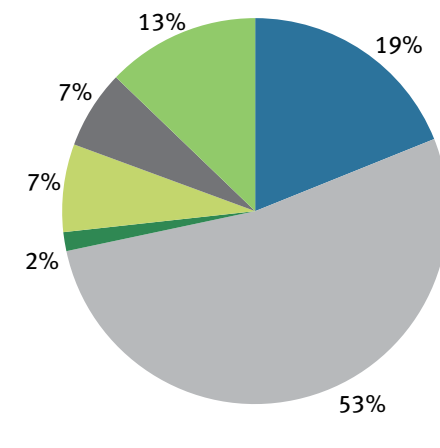

Imports, per cent of total

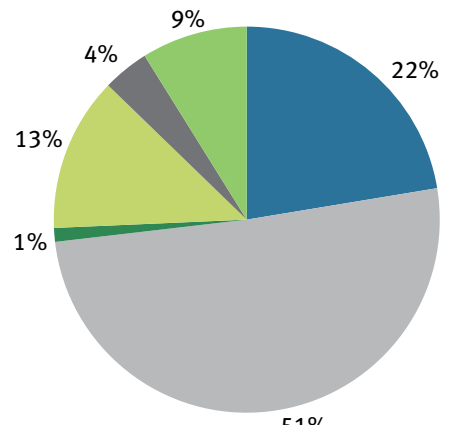

$51 \%$

- Nordic countries - $19 \%$

- EU27 (excl. DK, SE and FI) - 53\%

- Other Europe $-2 \%$

@ BRIC countries $-7 \%$

- United States and Canada - 7\%

nest of the world $-13 \%$

- Nordic countries - $22 \%$

EU27 (excl. DK, SE and FI) - 51\%

- Other Europe $-1 \%$

BRIC countries - $13 \%$

- United States and Canada - 4\%

- Rest of the world $-9 \%$ 


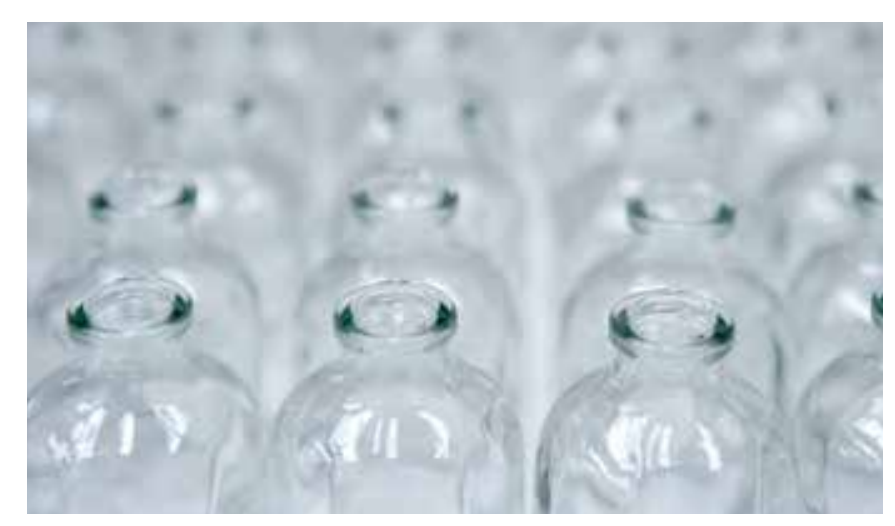

Exports

The EU27 and the Nordic countries are the largest trade partners when it comes to exports - especially Germany. The Netherlands and the USA are also major trading partners.

A common characteristic in the exports of the Nordic countries is a concentration on a few products. The exports of Greenland and the Faroe Islands are entirely dominated by fish and fish products, to a lesser extent in Iceland where aluminium exports also contribute significantly. Oil and gas are the predominant products exported by Norway, and Finnish exports are dominated by wood, paper and paper products and telecommunica- tion equipment. Danish and Swedish exports are more equally distributed on different products, with processed food, pharmaceuticals and chemical products as the major Danish export products and cars, wood, paper products and telecommunication equipment as predominant in Swedish exports.

\section{Export}

När det gäller export av varor är handeln störst med EU, de nordiska länderna och, framför allt, Tyskland. Nederländerna och USA är också stora handelspartner.

Exports by commodity. 2013

Table 12.4

Export. fördelning på varor

Denmark

Faroe Islands

Greenland

Finland

Iceland

Million euro

Total

82959

816

371

56034

3762

Norway

Per cent

Total

Food and live animals

Beverage and tobacco

Crude materials. inedible

Mineral fuels. lubricants and related materials

Animal and vegetable oils, fats and waxes

Chemicals and related products

Manufactured goods classified chiefly by material

Machinery and transport equipment

Miscellaneous manufactured articles

Other commodities and transaction

$\mathbf{1 0 0 . 0}$

Source: National statistical institutes and Eurostat

Note: Greenland: 2012 data.

Not: Gönland: 2012 àrs uppoifter.

$\begin{array}{rrrrr}\mathbf{1 0 0 . 0} & \mathbf{1 0 0 . 0} & \mathbf{1 0 0 . 0} & \mathbf{1 0 0 . 0} & \mathbf{1 0 0 . 0} \\ 17.4 & 91.6 & 90.6 & 2.3 & 44.0 \\ 1.2 & 0.0 & 0.0 & 0.3 & 0.2 \\ 4.8 & 1.7 & 0.1 & 8.5 & 1.6 \\ 9.5 & 1.6 & 0.0 & 12.5 & 1.6 \\ 0.6 & 1.9 & 0.0 & 0.0 & 2.7 \\ 18.0 & 0.1 & 0.0 & 8.2 & 2.4 \\ 9.0 & 0.7 & 3.3 & 26.9 & 41.1 \\ 24.5 & 2.1 & 0.9 & 27.4 & 3.9 \\ 7.0 & 0.2 & 0.3 & 4.8 & 1.9 \\ 8.1 & 0.0 & 4.9 & 9.0 & 0.5\end{array}$

116200
Sweden

126274

Miljoner euro

Procent

Livsmedel och levande Tiur

$\begin{array}{rrr}0.1 & 0.7 & \text { Drycker och tobak } \\ 1.5 & 6.6 & \text { Råaror. icke ätbara } \\ 67.4 & 8.4 & \text { Mineralbränslen. smörioljor och tillhörande material }\end{array}$

$\begin{array}{rrr}0.1 & 0.7 & \text { Drycker och tobak } \\ 1.5 & 6.6 & \text { Råaror. icke ätbara } \\ 67.4 & 8.4 & \text { Mineralbränslen. smörioljor och tillhörande material }\end{array}$ Mineralbränslen. smörjoljor och illho oljor och fetter Produkter av kemiska och närstact Bearbetade varor Mask. och apparater samt transpc Diverse färdiga varor Övriga varor 


\section{Imports}

Gemensamt för de nordiska ländernas export är koncentrationen på ett begränsat antal produkter. Grönlands och Färöarnas export domineras helt av fisk och fiskprodukter, något som också, om än mindre uttalat, gäller Island, vars aluminiumexport bidrar med en ansenlig del av exporten. Norges export domineras av olja och gas, Finlands av trävaror, papper och pappersvaror samt telekomutrustning. Dansk och svensk export är mer jämnt fördelad på ett antal huvudsakliga exportvaror, i Danmarks fall livsmedelsprodukter, mediciner och kemiska produkter och i Sveriges fall bilar, trävaror, pappersprodukter och telekomutrustning.
Import

Tyskland dominerar också helt de nordiska ländernas import. imports. However, the Nordic countries also have considerable imports from the Netherlands, China and Russia.
Norden har emellertid också en betydande import från Nederländerna, Kina och Ryssland.
Denmark

Million euro

Total

Per cent

Total

Food and live animals

Beverage and tobacco

Crude materials. inedible

Mineral fuels. lubricants and related materials

Animal and vegetable oils. fats and waxes

Chemicals and related products

Manufactured goods classified chiefly by materia

Machinery and transport equipment

Miscellaneous manufactured articles

Other commodities and transactions

72743

Faroe Islands

Greenland

72743

841

841

Fotr45

Source: National statistical institutes and Eurostat.

Note: Greenland: 2012 data.

önland: 2012 ars uppgifter.

$\begin{array}{rrrrr} & \text { Faroe Islands } & \text { Greenland } & \text { Finland } & \text { Iceland } \\ \mathbf{7 2} \mathbf{7 4 3} & & & & \\ & \mathbf{8 4 1} & \mathbf{6 7 1} & \mathbf{5 8 3 9 1} & \mathbf{3 5 9 9} \\ \mathbf{1 0 0 . 0} & \mathbf{1 0 0 . 0} & \mathbf{1 0 0 . 0} & \mathbf{1 0 0 . 0} & \mathbf{1 0 0 . 0} \\ 12.4 & 15.1 & 16.1 & 6.2 & 8.8 \\ 1.3 & 1.2 & 2.9 & 1.0 & 1.1 \\ 3.1 & 2.7 & 2.4 & 6.1 & 12.5 \\ 10.3 & 20.1 & 25.3 & 20.9 & 15.0 \\ 0.8 & 2.6 & 0.3 & 0.6 & 1.1 \\ 12.5 & 7.9 & 5.6 & 11.1 & 9.5 \\ 13.4 & 11.1 & 18.3 & 10.3 & 11.3 \\ 30.3 & 30.3 & 20.1 & 28.4 & 30.0 \\ 7.7 & 4.9 & 2.9 & 5.4 & 6.0 \\ 8.3 & 4.1 & 6.1 & 10.0 & 4.7 \\ & & & & \end{array}$

\begin{tabular}{l} 
celand \\
$\mathbf{3 5 9 9}$ \\
\\
$\mathbf{1 0 0 . 0}$ \\
8.8 \\
1.1 \\
12.5 \\
15.0 \\
1.1 \\
9.5 \\
11.3 \\
30.0 \\
6.0 \\
4.7 \\
\hline
\end{tabular}

Norway
$\mathbf{6 7 6 1 6}$

$\mathbf{1 0 0}$
6.7
1.2
5.6
7.1
1.0
9
14.5
38.7
8.0

\begin{tabular}{rr} 
way & Sweden \\
\hline $\mathbf{6 1 6}$ & $\mathbf{1 2 0} \mathbf{3 3 7}$ \\
& \\
\hline $\mathbf{0 0 . 0}$ & $\mathbf{1 0 0 . 0}$ \\
$\mathbf{6 . 7}$ & 9.0 \\
1.2 & 1.0 \\
5.6 & 3.1 \\
7.1 & 14.4 \\
1.0 & 0.4 \\
9.0 & 11.6 \\
14.5 & 12.8 \\
38.7 & 35.7 \\
8.0 & 6.8 \\
8.3 & 5.3
\end{tabular}

Miljoner euro

Totalt

Livsmedel och levande ditt

Livsmedel och levande dju

Drycker och tobak

Råvaror. icke ätbara

Mineralbränslen. smörjoljor och tillhörande materia

Animaliska och vegetabiliska oljor och fetter Produkter av kemiska och närstående industrie

Bearbetade varor

Mask. och apparater samt transportmedel Diverse färdiga varo Övriga varor 


\section{Public finance and prices Offentlig ekonomi och priser}

The Nordic countries are often characterized as public welfare societies because the public sector takes care of many different tasks in addition to defence, law, public order and safety. Tax rates are also among the highest in the world.

National budgets are the governments' way of mapping out the direction of economic policy. Governments use budgets to pursue their policies, and the effects can be felt in households, businesses and other organisations. The state budget itself is affected by external circumstances such as the general domestic and international macro-economic climate.

Tax policy is closely linked to the national budget and economy.
De nordiska länderna betecknas ofta som välfärdssamhällen, eftersom den offentliga sektorn sköter många olika uppgifter förutom försvar och rättsväsende. Skatterna är också bland de högsta i världen.

I statsbudgeten anger regeringarna den ekonomiska politikens inriktning. Statsbudgeten är ett viktigt verktyg för regeringspolitiken och berör både hushåll, företag och organisationer. Statsbudgeten påverkas i sin tur av yttre omständigheter som det ekonomiska läget såväl inom ett lands gräns som i omvärlden.

Skattepolitik har en stark koppling till samhällsekonomi och statsbudget.

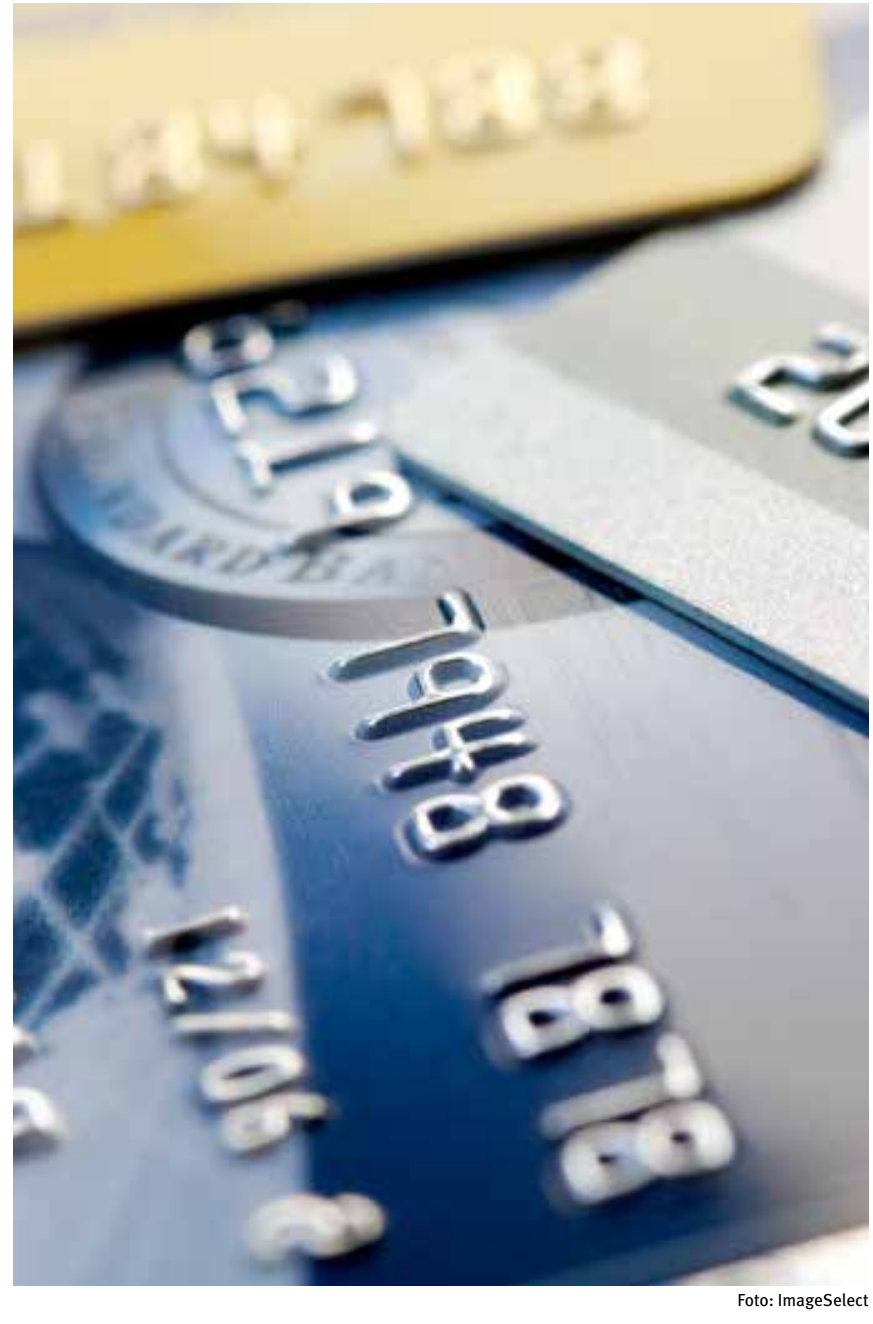




\section{iso}

\section{General government expenditure}

In all the Nordic countries, a large proportion of government

expenditure is spent on social goods, and all the countries share the same pattern of public expenditure - high levels of expendi-

ture for social security, health care and education. A minor

proportion is spent on investments in public buildings and to subsidize trade and industry.
Offentliga utgifter

I alla nordiska länder går en stor del av utgifterna till sociala förmåner och i alla länderna visar de offentliga utgifterna samma mönster - höga utgiftsnivåer för social trygghet, sjukvård och utbildning. En mindre del används till investeringar i offentliga byggnader och för att subventionera näringslivet.

General government expenditure by type of transaction. 2013

Offentliga utgifter efter transaktionstyp

\begin{tabular}{lrrrrrrr} 
& Denmark & $\begin{array}{r}\text { Faroe } \\
\text { Islands }\end{array}$ & Greenland & Finland & Iceland & Norway & Sweden \\
\hline Million euro & & & & & & & \\
Eiljoner euro
\end{tabular}

Capital transfers to other sectors

Source: Eurostat and national statistical institutes.

Note: 1) Consolidated data = current and capital transfers and interest payments to other general government units eliminated. 2) Includes acquisitions less disposals of non-financial non-produced assets. Faroe Islands: 2011 data.

Greenland: 1 Konsoliderade uppgiffter = löpande och kapitaltransfereringar samt räntor till andra offentliga myndigheter är eliminerade. 2) Inkluderar anskaffningar reducerade med disponibla icke-finansiella och icke-producerade tillgångar.

Färöarna: 2011 års uppgifter. Grönland: 2012 års uppgifter. Sverige: 2012 ărs uppgifter. 
Denmark Faroe Islands

Greenland

Finland Percent

Total

General public services

Defence

Public order and safety

Economic affairs

Environmental protection

Housing etc.

Health

Recreation, culture and religion

Education

Social protection

$\begin{array}{rr}\mathbf{1 0 0 . 0} & \mathbf{1 0 0 . 0} \\ 15.1 & 12.2 \\ 2.5 & - \\ 1.9 & 2.3 \\ 6.2 & 10.4 \\ 0.7 & 1.9 \\ 0.6 & 1.1 \\ 14.5 & 13.9 \\ 2.8 & 3.3 \\ 13.3 & 15.5 \\ 42.5 & 39.3\end{array}$

Pubs13

Source: Eurostat and national statistical institutes.

Note: Faroe Islands: 2011 data.

Not: Färöarna: 2011 års uppgifter.

Did you know that ... the role taxes play in the Nordic countries as part of GDP has risen considerably over the last 50 years. In the beginning of the sixties the share ranged between 20 and 30 per cent of GDP to now between 37 and 49 per cent.

Visste du att ... den roll skatter spelar som en del av BNP i de nordiska länderna har ökat betydligt under de senaste 50 åren. I början av sextiotalet varierade andelen mellan 20 och 30 procent av BNP och nu är den mellan 37 och 49 procent.

$\begin{array}{rrrrrr} & & & & \text { Procent } \\ \text { 95.4 } & \mathbf{1 0 0 . 0} & \mathbf{1 0 0 . 0} & \mathbf{1 0 0 . 0} & \mathbf{1 0 0 . 0} & \text { Totalt } \\ 11.7 & 13.1 & 19.2 & 9.2 & 13.9 & \text { Allmänna offentliga tjänster } \\ \text { Försvar } \\ 1.2 & 2.8 & 0.0 & 3.3 & 2.8 & \text { Rättsväsen etc. } \\ 6.3 & 2.7 & 3.1 & 2.2 & 2.8 & \text { Ekonomiska angelägenheter } \\ 11.2 & 8.6 & 10.4 & 9.8 & 8.5 & \text { Milj̈̈skydd } \\ 1.0 & 0.4 & 1.3 & 1.6 & 0.7 & \text { Bostäder etc. } \\ 4.1 & 0.8 & 2.4 & 1.5 & 1.4 & \text { Hälsovård } \\ 14.4 & 14.4 & 16.3 & 16.9 & 13.7 & \text { Fritidsverksamhet, kultur och religion } \\ 3.7 & 2.2 & 6.9 & 2.8 & 2.1 & \text { Utbildning } \\ 19.4 & 11.2 & 16.9 & 12.6 & 13.1 & \text { Social trygghet } \\ 27.0 & 43.7 & 23.5 & 40.1 & 41.2 & \end{array}$

General government expenditure by function. 2012 Offentliga utgifter efter ändamà

Figure 13.1

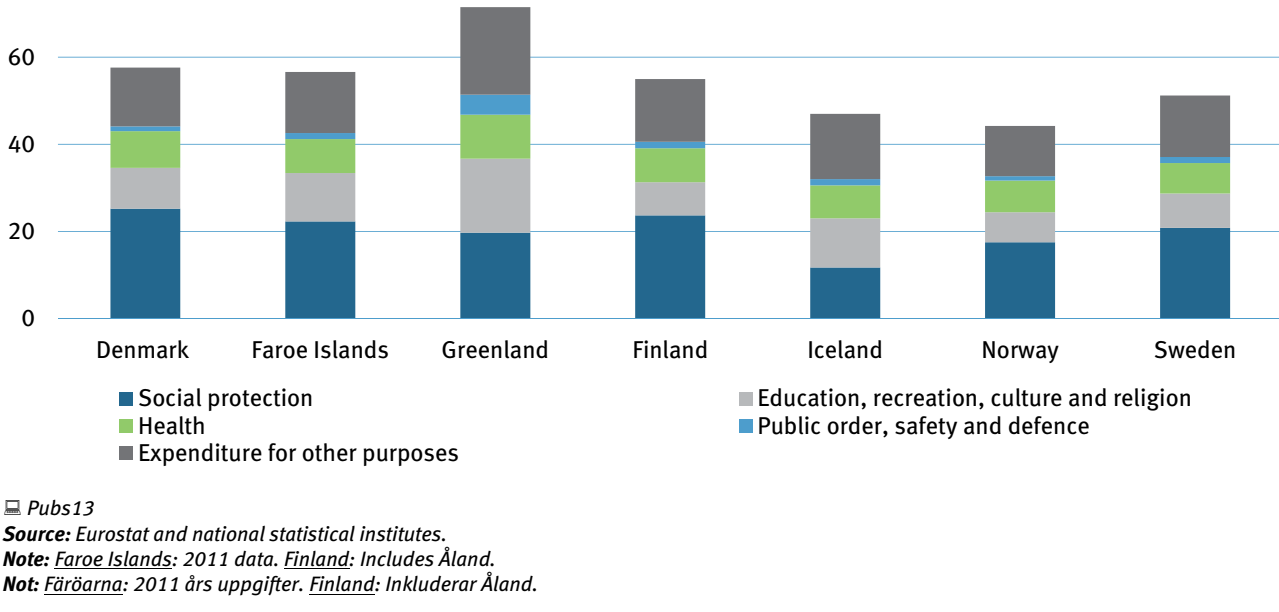




\section{General government revenue}

General government expenditure is normally financed by means of taxes and social security contributions, which account for 37 to 49 per cent of GDP in the Nordic countries. The tax rate is the highest in Denmark and the lowest in Iceland.

In the Nordic countries, taxes and social security contributions account for 74 to 87 per cent of total public revenue. Finland and Norway have the lowest proportions and Sweden the highest. In addition to tax revenues, revenues can for example come from capital revenue

The Nordic countries have different tax structures. For example, income taxes are more important in Denmark than in the other Nordic countries. On the other hand, social security contributions are of less importance in Denmark.

\section{Per cent of GDP}

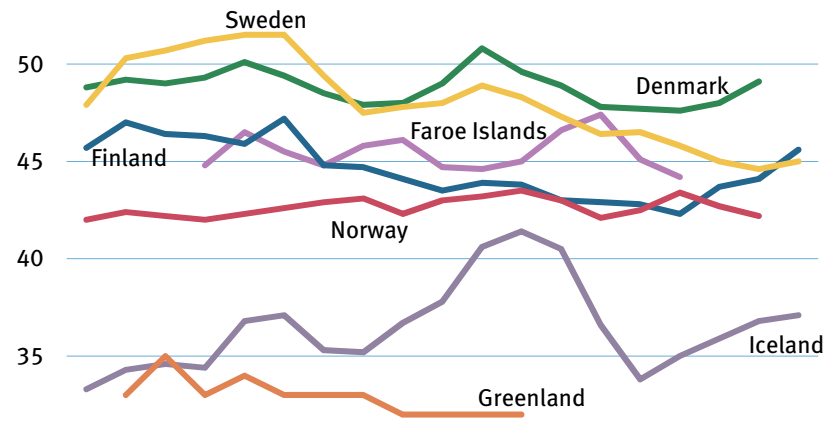

30 $\begin{array}{llllllllll}1995 & 1997 & 1999 & 2001 & 2003 & 2005 & 2007 & 2009 & 2011 & 2013\end{array}$ 마bs 12 Source: Eurostat and national statistical institutes.
Offentliga inkomster

De offentliga utgifterna finansieras vanligen med skatter och sociala avgifter, vilka i Norden utgör mellan 37 och 49 procent av BNP. Skattekvoten är högst i Danmark och lägst på Island.

Skatter och sociala avgifter i Norden svarar för 74-87 procent av de totala offentliga intäkterna. Finland och Norge har den lägsta andelen och Sverige den största. Förutom skatteinkomster kan intäkterna till exempel komma från kapitalinkomster.

Skattestrukturen skiljer sig åt mellan de nordiska länderna. Inkomstskatten har t.ex. en större betydelse i Danmark än i de övriga nordiska länderna. Å andra sidan spelar de sociala avgifterna en mindre roll i Danmark.

Skatte

\section{Million euro}

Denmark

Faroe Islands Finland Iceland Norway Sweden

1738

193443




\section{Budget deficit}

For a number of years, all the Nordic countries, except Iceland, have had a general government surplus. This changed in 2010 and in 2012, only Norway came out with a surplus amounting to 13.8 per cent of GDP. Most other West European countries have a general government deficit.

In the Nordic countries, general government gross debt varies between 30 and 53 per cent of GDP - except for Iceland (almost 100 per cent). Consequently, all the Nordic countries, except Denmark and Iceland, met the so-called convergence criteria that apply to the EU member countries in 2012. The convergence criteria stipulate, among other things, that the member countries must not have a budget deficit of more than 3 per cent of GDP and that the gross debt must not exceed 60 per cent of GDP.

\section{Budgetunderskott}

Under ett antal år hade alla de nordiska länderna utom Island ett offenligt överskott. Detta ändrades under 2010 och i 2012 hade endast Norge ett överskott vilket uppgick till 13,8 procent av BNP. De flesta andra västeuropeiska länder har ett offentligt underskott.

Den offentliga sektorns bruttoskuld i de nordiska länderna varierar mellan 30 och 53 procent av BNP - med undantag för Island (nästan 100 procent). Alla de nordiska länderna, utom Danmark och Island, uppfyllde därmed de s.k. konvergenskriterierna för EU:s medlemsländer under 2012. Konvergenskriterierna innebär bland annat att medlemsländerna inte får ha ett budgetunderskott på mer än 3 procent av BNP och att den offentliga sektorns bruttoskuld inte får överstiga 60 procent av BNP.

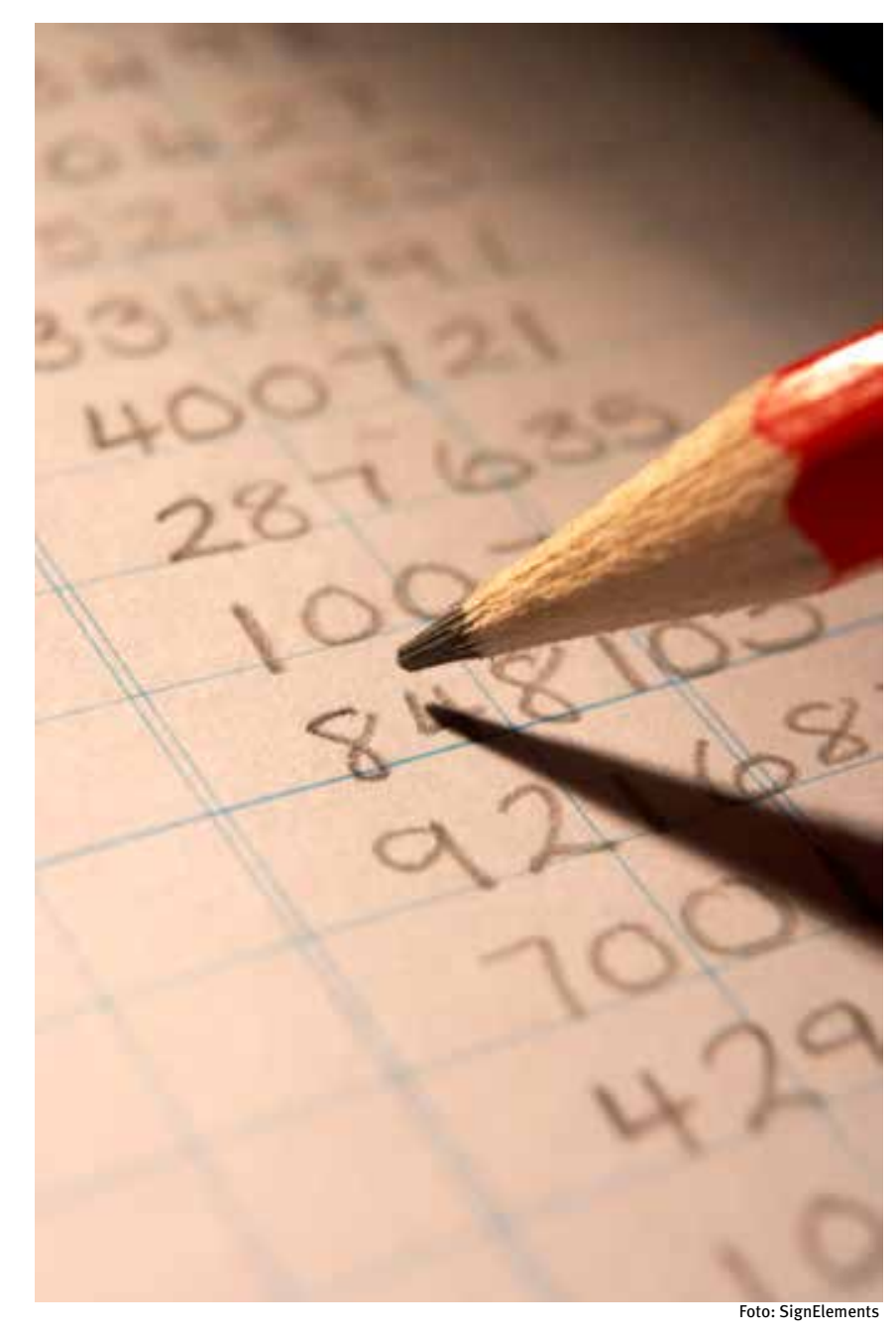

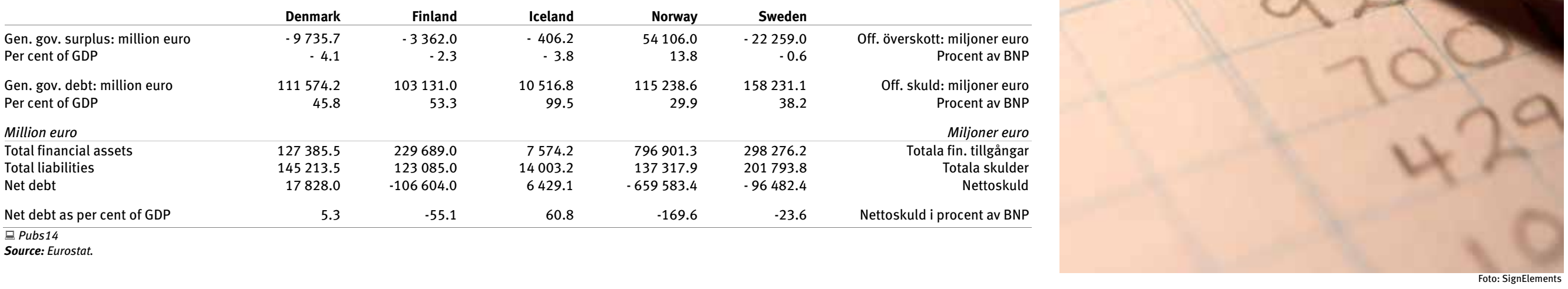




\section{Debt}

In all the Nordic countries, gross debt has amounted to less than 60 per cent of GDP since 2000, except for Iceland. Compared to the 17 euro-countries, which, in 2011, had an average gross debt of 87 per cent of GDP and a general government deficit of 6 per cent, the Nordic countries constitute strong public finances.

When it comes to net debt, Denmark and Iceland are the only Nordic countries which owe more money than their financial assets. The public sectors in the other countries all have negative net debts, i.e. net positive financial assets.

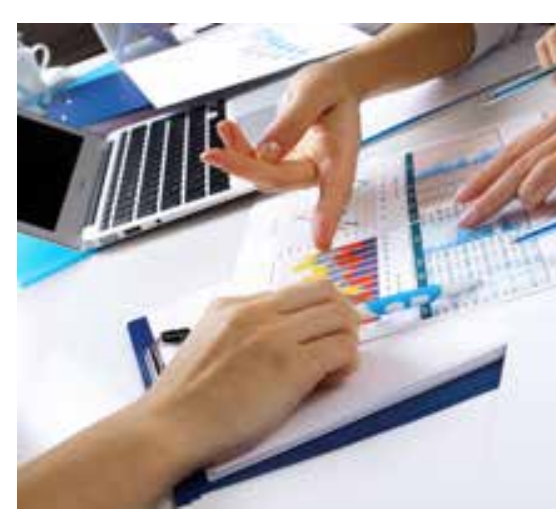

Figure 13.3

General government gross debt

Offentliga sektorns bruttoskuld

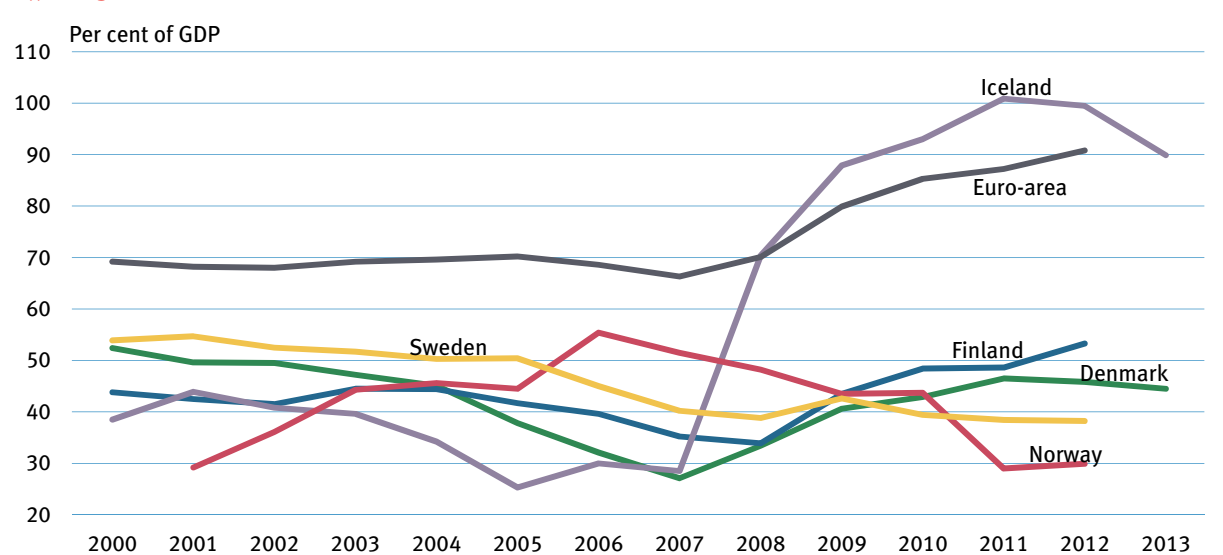

Sedan 2000 har alla de nordiska länderna, utom Island, haft en bruttoskuld på mindre än 60 procent av BNP. Jämfört med de 17 euroländerna, vilka år 2011 tillsammans hade en genomsnittlig bruttoskuld på 87 procent av BNP och ett offentligt underskott på 6 procent, uppvisar de nordiska länderna starka offentliga finanser.

Ser man på nettoskulden är det endast den offentliga sektorn i Danmark och på Island som är skyldig mera pengar än man har tillgodohavanden. Den offentliga sektorn i de andra länderna

har en negativ nettoskuld, alltså en positiv finansiell netto-

\section{förmögenhet.}

General government net debt

Offentliga sektorns nettoskuld

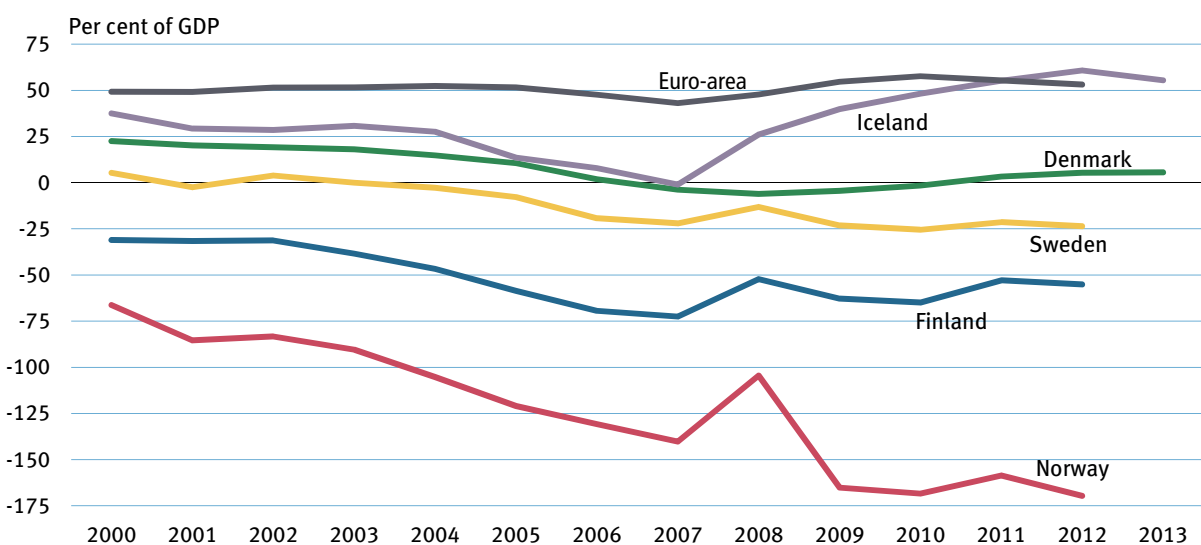

$\square$ Pubs14

Source: Eurostat and national statistical institutes.

as their common currency.

Source: Eurostat and national statistical institutes.

ed the euro as their common

. 


\section{Development aid}

Since 1990, the Nordic countries have lowered their development aid, measured as a percentage of the gross national income (GNI). The exception is Iceland which from a modest share of 0.10 per cent of GNI in 1997 now has a share of 0.26 per cent.

Norway, Sweden and Denmark are among the countries in the world that contribute with the largest development aid in relation to their national income. As a percentage of gross national income, Finland's development aid is at the same level as the OECD countries' average amount of development aid as share of total GNI.

Internationellt bistånd

Sedan 1990 har de nordiska länderna sänkt sitt utvecklingsbistånd, mätt i procent av bruttonationalinkomsten (BNI). Undantaget är Island, som med en måttlig procent på 0,10 år 1997 nu ligger på 0,26 procent.

Danmark, Norge och Sverige hör till de länder i världen som, förhållande till nationalinkomsten, ger det största biståndet. Mätt i procent av bruttonationalinkomsten är Finlands internationella bistånd av samma storlek som genomsnittet av OECD-ländernas bistånd räknat som andel av BNI.
Per cent of gross national income (GNI)

0.8

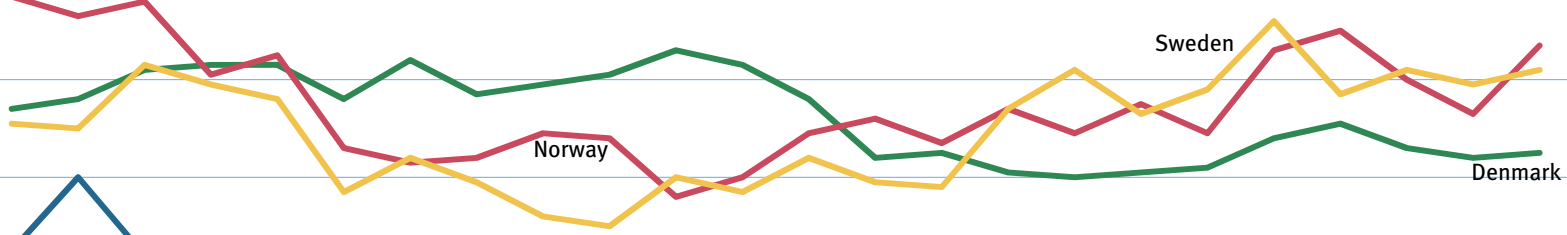

0.6

0.2

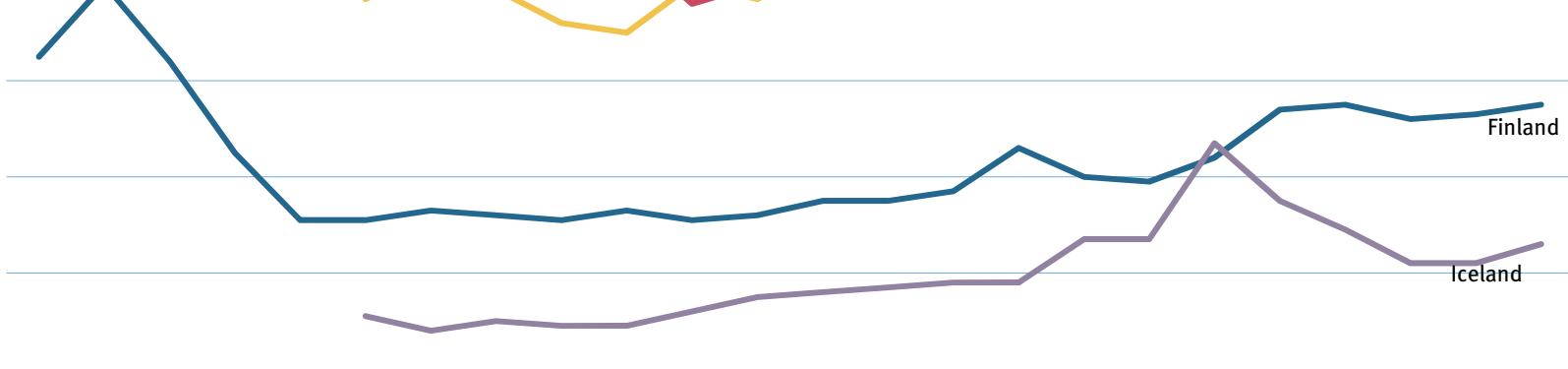

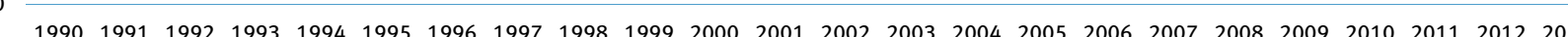

马 Ofde02 
Statligt internationellt bistånd

1990

Net disbursements in million USD

Bilateral flow

Multilateral flow

Per cent of GNI

2012

Net disbursements in million USD

Total

Bilateral flow

Multilateral flow

Finland

Iceland

Norway

Sweden

$1171 \quad 846$

$695 \quad 498$

$476 \quad 348$

0.94

0.65

8
3
5
0.10

1205

756
449

2007

1379
628

$1.17 \quad 0.91$

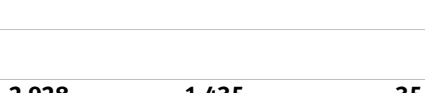

Per cent of GNI

2145

783

820

0.85

0.55

35
30
0

4471

4316

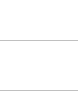

1.07

3931

0.26

Source: $O E C D$.

Note: Iceland: 1990 refers to 1997.

Not: Island: 1990 avser 1997 års uppgifter.

1.02

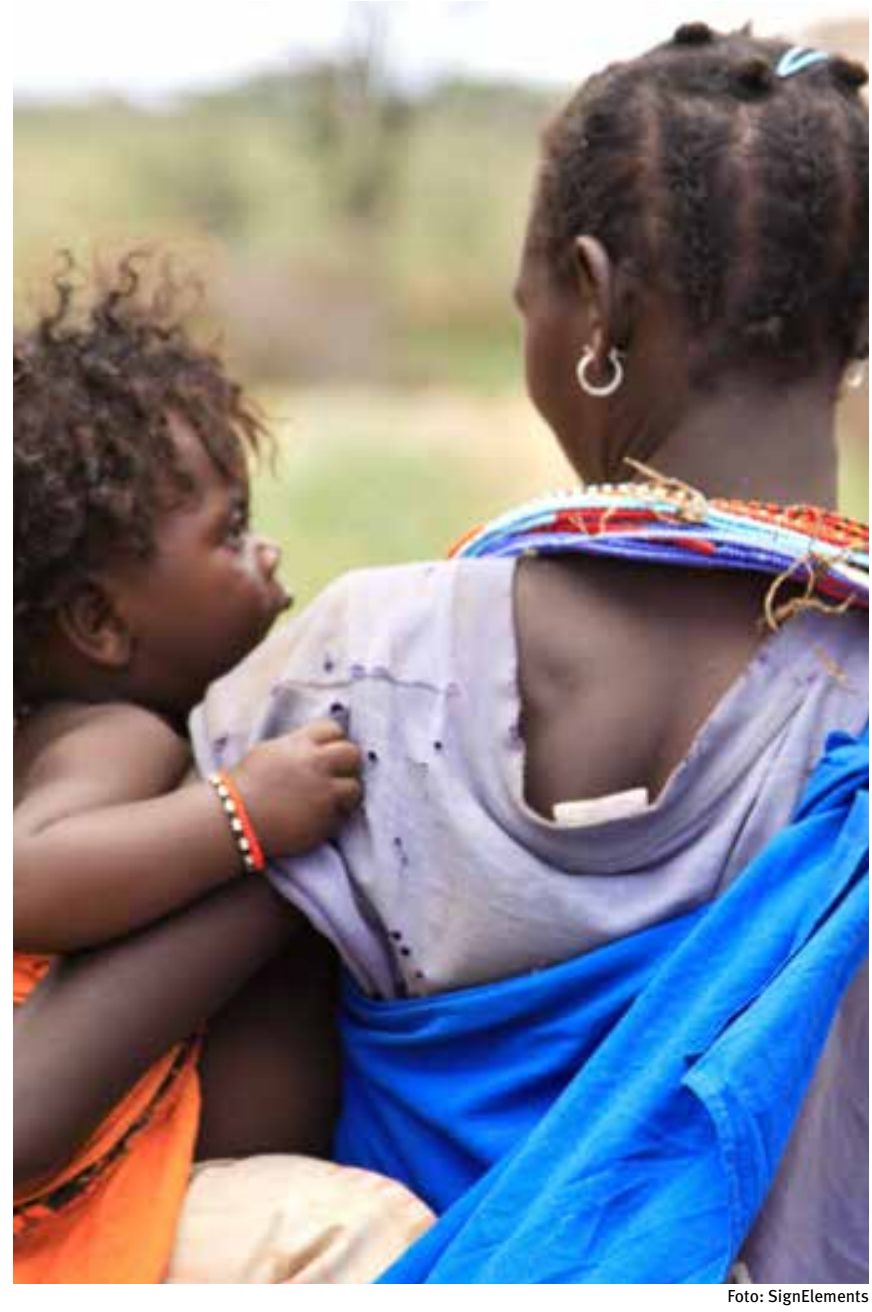

Public finance and prices · Offentlig ekonomi och prise
Nettoutgifter i miljoner USD

Nettoutgifter i miljoner USD

Bilateralt flöde

Multilateralt flöde

Procent av BNI 


\section{Consumer prices}

The consumer price index is an indicator of developments in the general level of prices. The consumer index is split into several different sub-indices to enable analysis of specific groups of products and services where the changes have been most significant. All the Nordic countries have experienced moderate price increases since the late 1990s. During the period from 2005 , though, consumer prices have increased a lot in Iceland, by 69 per cent. Sweden has had the lowest increase of all the Nordic countries during the same period - by 14 per cent.

Consumer price index. 2013

Figure 13.6 Konsumentprisindex

Index $2005=100$

180
170
160
150
140
130
120
1
1

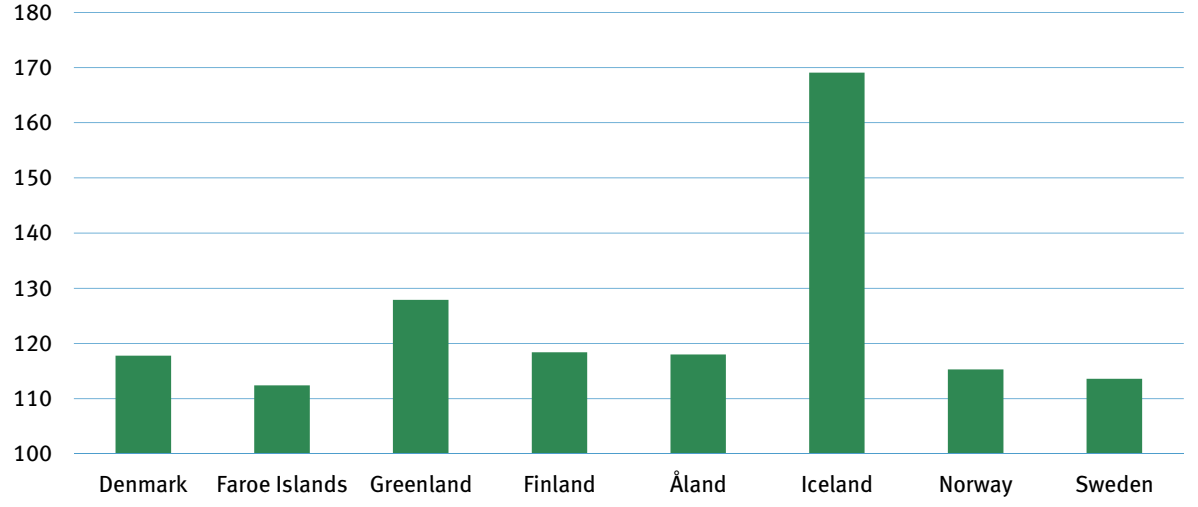

모 Pric01

Source: National statistical institutes.

5. Finland: Includes Ålan

.
Konsumentpriser

Konsumentprisindexet är en indikator på förändringen i den allmänna prisnivån. Indexet är uppdelat i flera olika delindex för att man skall kunna analysera enskilda grupper av varor och tjänster där förändringarna varit särskilt märkbara. Alla de nordiska länderna har haft måttliga prisökningar sedan slutet av 1990-talet. Sedan 2005 har konsumentpriserna ökat mycket på Island (med 69 procent). Sverige har haft den lägsta ökningen av alla de nordiska länderna under samma period, nämligen 14 procent.

Consumer price index: Food and non-alcoholic beverages Konsumentprisindex: Livsmedel och alkoholfria drycker

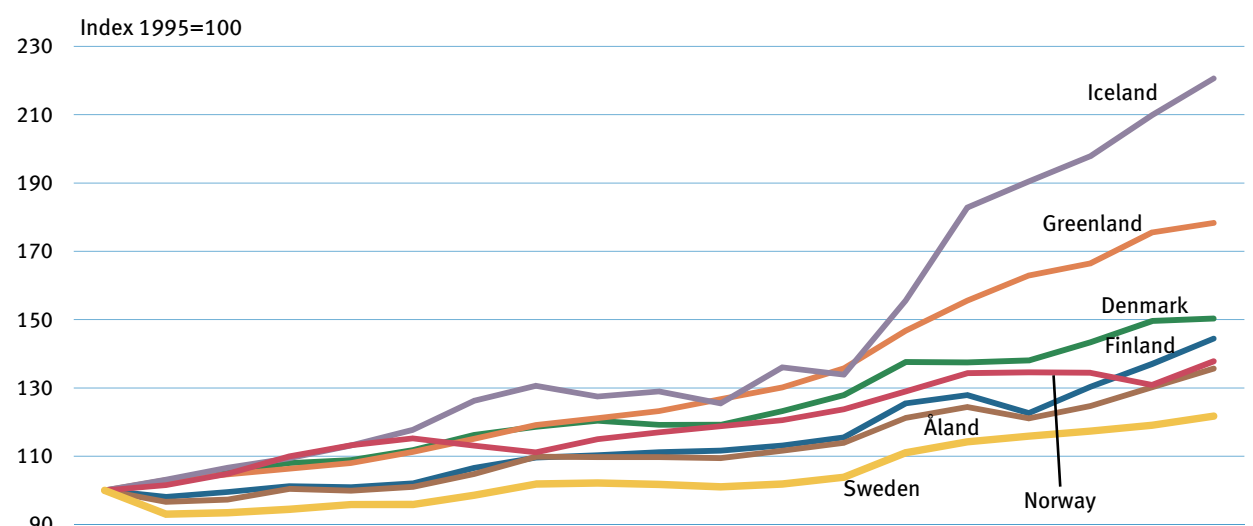

1995199619971998199920002001200220032004200520062007200820092010201120122013 
Total

Food and non-alcoholic beverages Alcoholic beverages and tobacco

Clothing and footwear

Housing, water, electricity, fuels

Furnishings, household equipment

Transpo

Communications

Recreation and culture

Education

Restaurants and hotels

Miscellaneous goods and services

DPric01

Source: National statistical institutes. Note: Finland: Includes Åland.

$\begin{array}{rrr}\mathbf{1 1 2 . 4} & \mathbf{1 1 3 . 8} & \mathbf{1 1 8 . 4} \\ 120.0 & 121.5 & 129.4 \\ 124.6 & 109.8 & 134.3 \\ 104.3 & 100.4 & 104.2 \\ 126.5 & 127.6 & 125.3 \\ 95.4 & 116.0 & 113.4 \\ 104.7 & 121.8 & 110.4 \\ 116.1 & 112.7 & 117.6 \\ 91.4 & 95.5 & 77.8 \\ 99.9 & 95.3 & 105.2 \\ 117.7 & . . & 127.4 \\ 123.8 & 112.6 & 129.0 \\ 124.7 & 106.1 & 118.8\end{array}$

18.4
129.4
34.3
04.2
25.3
13.4
10.4
17.6
77.8
105.2
17.4
129.0
18.8

$\mathbf{1 1 8 . 0}$
124.0
134.2
100.4
133.7
114.1
112.9
115.6
77.3
104.3
167.4
126.0
120.1

169.1
175.8
191.6
158.1
162.7
179.2
147.5
206.1
152.6
148.7
142.9
155.9
161.0

115.3

116.0

134.0
77.0

77.0

126.0

126.0

121.0

80.0

110.0

110.0

132.0

121.0

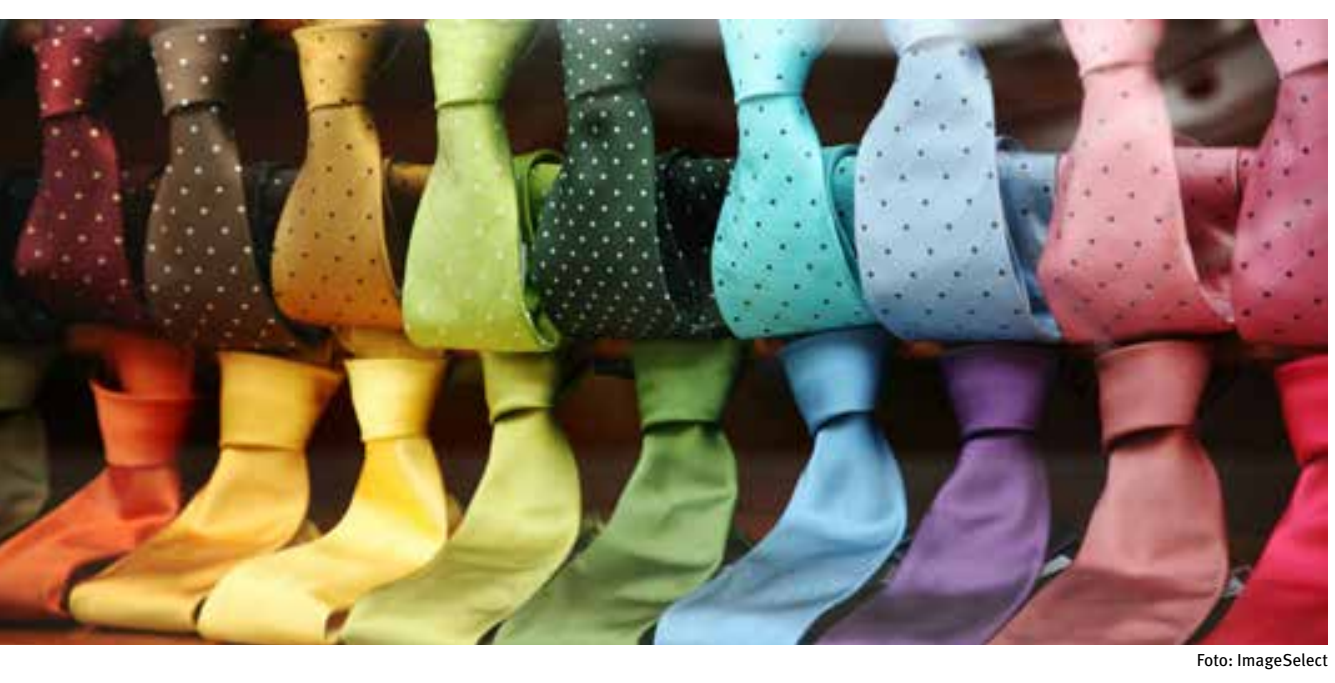

Index $2005=100$

$\mathbf{1 1 3 . 6}$
120.5

120.5
130.6

110.6

118.9

118.9

95.6
113.0

113.0
116.4
77.2

$124 . \overline{5}$

Totalt

Livsmedel och alkoholfria drycker Alkoholhaltiga drycker och tobak

Kläder och skor Inventarier, hushållsutrustning Hälsovård
Transport Rekreation och kultur Utbildning Restauranger och hotell Restauranger och hotell
Diverse varor och tjänster 


\section{Price levels}

The price levels in the five Nordic countries for food only and for all goods and services included in the gross domestic product (GDP), respectively, are shown here. In both cases the average price level in the 27 countries who are members of the European Union is fixed at index 100 (EU27=100). The prices on which the price comparisons are based are the prices paid by the consumers, i.e. the prices including VAT and other taxes. The price level indices are calculated by means of the PPP exchange rates since the official exchange rates do not typically reflect the real differences in price levels. Specifically, price level indices are calculated as the ratio between PPP exchange rates and the official exchange rates.

Food is particularly expensive in Norway and Denmark. In 2013 the price level of food in these two countries was 75 per cent (Norway) and 36 per cent (Denmark) higher than the EU27 average. Iceland was the least expensive Nordic country with respect to food.

The price differences between the Nordic countries are smaller in respect of the aggregate price level, i.e. the prices of all goods and services included in GDP. Here again, Iceland is the least expensive country with a 2013 price level 13 per cent higher than the EU27 average, while Norway is the most expensive with a price level 54 per cent higher than the EU27 average.
Price levels. 2013

Prisnivåer

$$
\text { Index EU27 }=100
$$

\section{0}

160

140

120

100

80

60

40

20

0

Denmark Finland Iceland Norway Sweden EA17 EU27 - GDP $\square$ Food

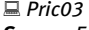
Source: Eurostat.

Note: EA17: The 17 member states that have adopted the euro as their common currency. EU27: The 27 member countries of the European Union as of 1 January 2013. Not: EA17: De 17 earopeiska la of the Europ har Uhort euron som gemensam valuta.
Prisnivåer i de fem nordiska länderna för livsmedel respektive samtliga varor och tjänster som ingår i bruttonationalprodukten visas i tabell- och diagramdelen. I båda fallen är den genomsnittliga prisnivån i de 27 EU-länderna satt till 100 (EU27=100). De priser som ligger till grund för jämförelserna är de priser som konsumenterna måste betala, alltså priser inklusive moms och andra avgifter. Prisnivåindexen har beräknats med hjälp av köpkraftspariteter då de officiella valutakurserna inte avspeglar de verkliga skillnaderna i prisnivåerna. Rent konkret har prisnivåindexen beräknats som förhållandena mellan köpkraftspariteterna och de officiella valutakurserna.

Livsmedel är särskilt dyrt i Norge och Danmark. I de två länderna låg prisnivån på livsmedel år 201375 procent (Norge) och 36 procent (Danmark) över EU27-genomsnittet. Island var Nordens billigaste land när det gäller livsmedel.

Prisskillnaderna mellan de nordiska länderna är mindre när det gäller den samlade prisnivån, d.v.s. priserna på samtliga varor och tjänster som ingår i BNP. Här är Island det billigaste landet med en prisnivå år 2013 som ligger 13 procent över EU27-genomsnittet, medan Norge är dyrast med en prisnivå 54 procent över EU27-genomsnittet. 


\section{GDP per capita in purchasing power}

Exchange rates do not adjust for differences in price levels between the countries. Therefore, the GDP of the different countries converted into a common currency using ordinary exchange rates will not only reflect real differences in GDP (and thus also in GDP per capita), but also differences in the price levels between the countries. Converting GDP using ordinary exchange rates thus gives a misleading picture. Such converting overestimates the size of the GDP of countries with relatively high price levels and underestimates the GDP of countries with low price levels. If, on the other hand, the PPS exchange rates are used, an adjustment is made for the difference in the price levels of the individual countries. Consequently, the PPS exchange rates should be applied in converting the GDP of different countries into a common currency for comparing GDP and GDP per capita.

The differences in GDP per capita between the Nordic countries are reduced significantly when PPS exchange rates are applied rather than the misleading official exchange rates. In 2013, the wealth level of all Nordic countries measured by a PPS-based index for GDP per capita was above the EA17 average. Norway exceeded the EU average by as much as 78 per cent, Sweden with 18 per cent came in second.
Bruttonationalprodukten per person

\begin{tabular}{lrrr} 
& $\begin{array}{r}\text { PPP } \\
\text { exchange } \\
\text { rates }\end{array}$ & $\begin{array}{r}\text { Official } \\
\text { exchange } \\
\text { rates }\end{array}$ & Index EA17=100 \\
\hline Index EA17=100 & & 155 & Danmark \\
Denmark & 116 & 124 & Finland \\
Finland & 104 & 118 & Nland \\
Iceland & 108 & 264 & Norge \\
Norway & 178 & 153 & Sverige \\
Sweden & 118 & 109 & Frankrike \\
France & 100 & 116 & Tyskland \\
Germany & 116 & 89 & Italien \\
Italy & 91 & 125 & Nederländerna \\
Netherlands & 118 & 35 & Polen \\
Poland & 63 & 103 & Storbritannien \\
United Kingdom & 98 & 48 & Estland \\
Estonia & 67 & 40 & Lettland \\
Latvia & 62 & 41 & Litauen \\
Lithuania & 69 & 100 & EA17 \\
EA17 & 100 & 90 & EU27 \\
EU27 & 93 & 139 & USA \\
United States & 144 & 117 & Japan \\
Japan & 96 & &
\end{tabular}

DPicou

Source: Eurostat.

Note: Japan: 2011 data. EA17: The 17 member states that have adopted the euro currency as their sole legal tender. EU27: The 27 member states of the European Union as Not: Japan: 2011 arrs uppgifter. EA17: De 17 europeiska länderna som har infört euron som gemensam valuta. EU27: De 27 medlemsstaterna i Europeiska unionen per
1 januari 2013.
BNP i köpkraft

De vanliga valutakurserna korrigerar, som nämnts, normalt inte skillnaderna i prisnivåer mellan länderna på ett korrekt sätt. Därför kommer de olika ländernas BNP, omräknade till en gemensam valuta genom användning av vanliga valutakurser, inte bara att avspegla verkliga skillnader i BNP (och därmed också BNP per invånare), utan också skillnader i prisnivåer mellan länderna. Att räkna om BNP genom användning av vanliga valutakurser ger därför en missvisande bild. En sådan omräkning övervärderar storleken av BNP för länder med relativt höga prisnivåer och undervärderar BNP i länder med låga prisnivåer. Används däremot PPS, korrigeras skillnader i ländernas prisnivåer. Därför bör PPS användas vid omräkning av olika länders BNP till en gemensam valuta när avsikten är att jämföra ländernas BNP och BNP per invånare.

Skillnaderna mellan de nordiska ländernas BNP per invånare blir betydligt mindre när man använder PPS i stället för de officiella valutakurserna. Samtliga nordiska länders välståndsnivå, mätt genom ett PPS-baserat index för BNP per invånare, låg år 2013 över EA17-genomsnittet. Norge låg hela 78 procent över EA17-genomsnittet, Sverige med 18 procent kom på andra plats. 
Exchange rates. The cost of euro and US dollar in Nordic currencies

Table 13.8

Växelkurser. Priset på euro och US dollar mätt i de nordiska ländernas valutor

\begin{tabular}{|c|c|c|c|c|c|c|}
\hline & $\begin{array}{r}\text { Danish } \\
\text { krone }\end{array}$ & $\begin{array}{r}\begin{array}{r}\text { Finnish } \\
\text { mark/euro }\end{array}\end{array}$ & $\begin{array}{r}\text { Icelandic } \\
\text { krona }\end{array}$ & $\begin{array}{r}\text { Norwegian } \\
\text { krone }\end{array}$ & $\begin{array}{r}\text { Swedish } \\
\text { krona }\end{array}$ & \\
\hline $\begin{array}{l}\text { Average value } \\
\text { of } 1 \text { euro }\end{array}$ & & & & & & $\begin{array}{l}\text { Genomsnittligt } \\
\text { värde av } 1 \text { euro }\end{array}$ \\
\hline 1990 & 7.8737 & 4.8640 & 74.2900 & 7.9660 & 7.5202 & 1990 \\
\hline 1995 & 7.2460 & 5.6440 & 83.7500 & 8.2858 & 9.3319 & 1995 \\
\hline 2000 & 7.4537 & 1.0000 & 72.6100 & 8.1109 & 8.4465 & 2000 \\
\hline 2005 & 7.4519 & 1.0000 & 78.1350 & 8.0073 & 9.2849 & 2005 \\
\hline 2010 & 7.4474 & 1.0000 & 161.8899 & 8.0068 & 9.5410 & 2010 \\
\hline 2013 & 7.4580 & 1.0000 & 160.7343 & 7.8100 & 8.6229 & 2013 \\
\hline $\begin{array}{l}\text { Average value } \\
\text { of } 1 \text { USD }\end{array}$ & & & & & & $\begin{array}{r}\text { Genomsnittligt värde } \\
\text { av } 1 \text { USD }\end{array}$ \\
\hline 1990 & 6.1853 & 3.8233 & 58.3100 & 6.2544 & 5.9100 & 1990 \\
\hline 1995 & 5.6053 & 4.3658 & 64.7800 & 6.3369 & 7.1300 & 1995 \\
\hline 2000 & 8.0903 & 0.9236 & 78.8700 & 8.8058 & 9.1718 & 2000 \\
\hline 2005 & 6.0034 & 1.2441 & 62.8579 & 6.4450 & 7.4775 & 2005 \\
\hline 2010 & 5.6257 & 1.3257 & 122.0422 & 6.0453 & 7.2050 & 2010 \\
\hline 2013 & 5.6160 & 1.3281 & 122.2305 & 5.8770 & 6.4904 & 2013 \\
\hline
\end{tabular}

Source: Central Bank of Denmark, Norway and Iceland, Bank of Finland and Sweden.

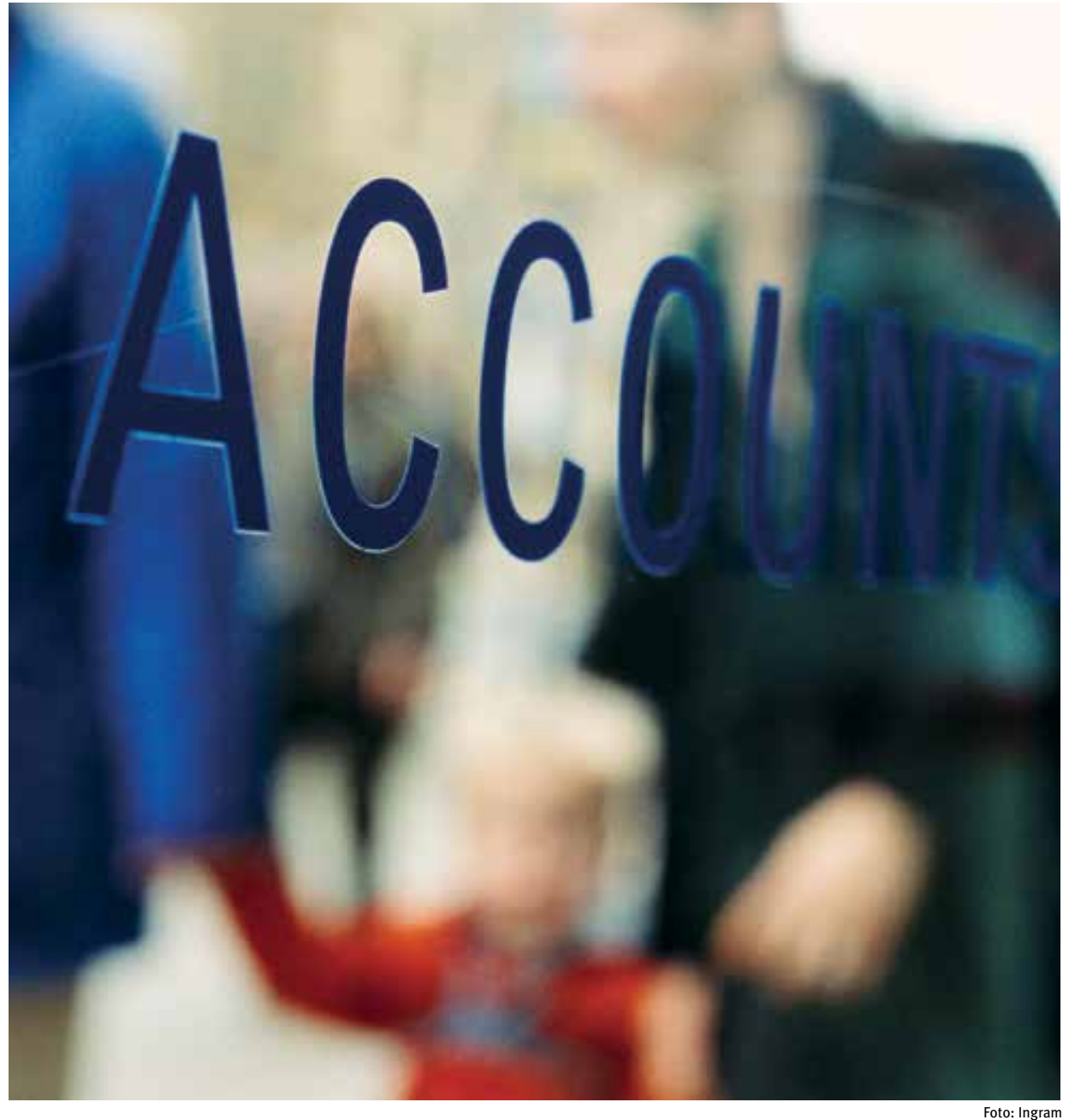

Foto: Ingram 


\section{Share prices}

The generally sound economic development of the Nordic countries is also reflected in increased share prices. From 2003 to the spring of 2007, share prices increased markedly in all Nordic countries - and definitely more than in the remaining West European countries. The increase happened after a considerable decrease in especially technological shares from 2000 to 2003.

From the end of 2007, Nordic shares have decreased drastically as a result of the general crisis in the world economy. Despite a turning point in 2009 the share prices have not yet fully recovered.

\section{Share prices}

Aktiekurser

250 Index 2005=100

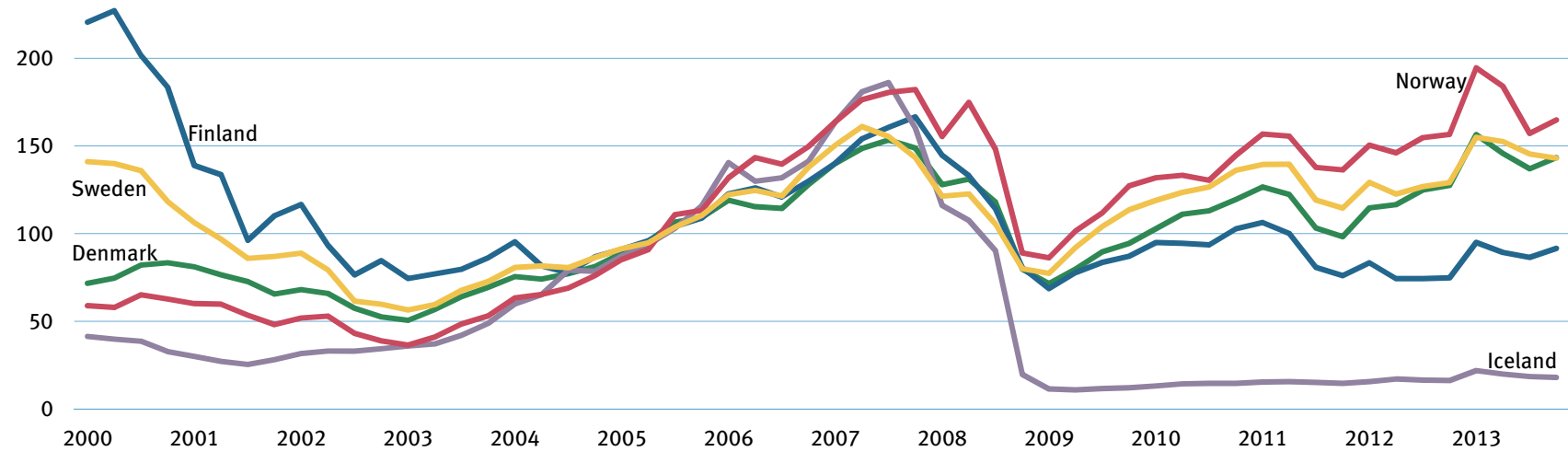

\section{Aktiekurse}

Den allmänt goda ekonomiska utvecklingen i de nordiska länderna har också resulterat i stigande aktiekurser. Från 2003 och fram till våren 2007 gick aktiekurserna upp markant i hela Norden - och klart mer än i de övriga västeuropeiska länderna. Kursökningen kom efter betydande fall åren 2000 till 2003 i synnerhet inom aktierna i teknologiföretag.

Sedan slutet av 2007 har alla de nordiska aktiekurserna fallit som ett resultat av den ekonomiska krisen. Trots en vändpunkt år 2009 har aktiekurserna ännu inte återhämtat sig.

Figure 13.9

Shar01

Source: OECD Main Economicindicators.

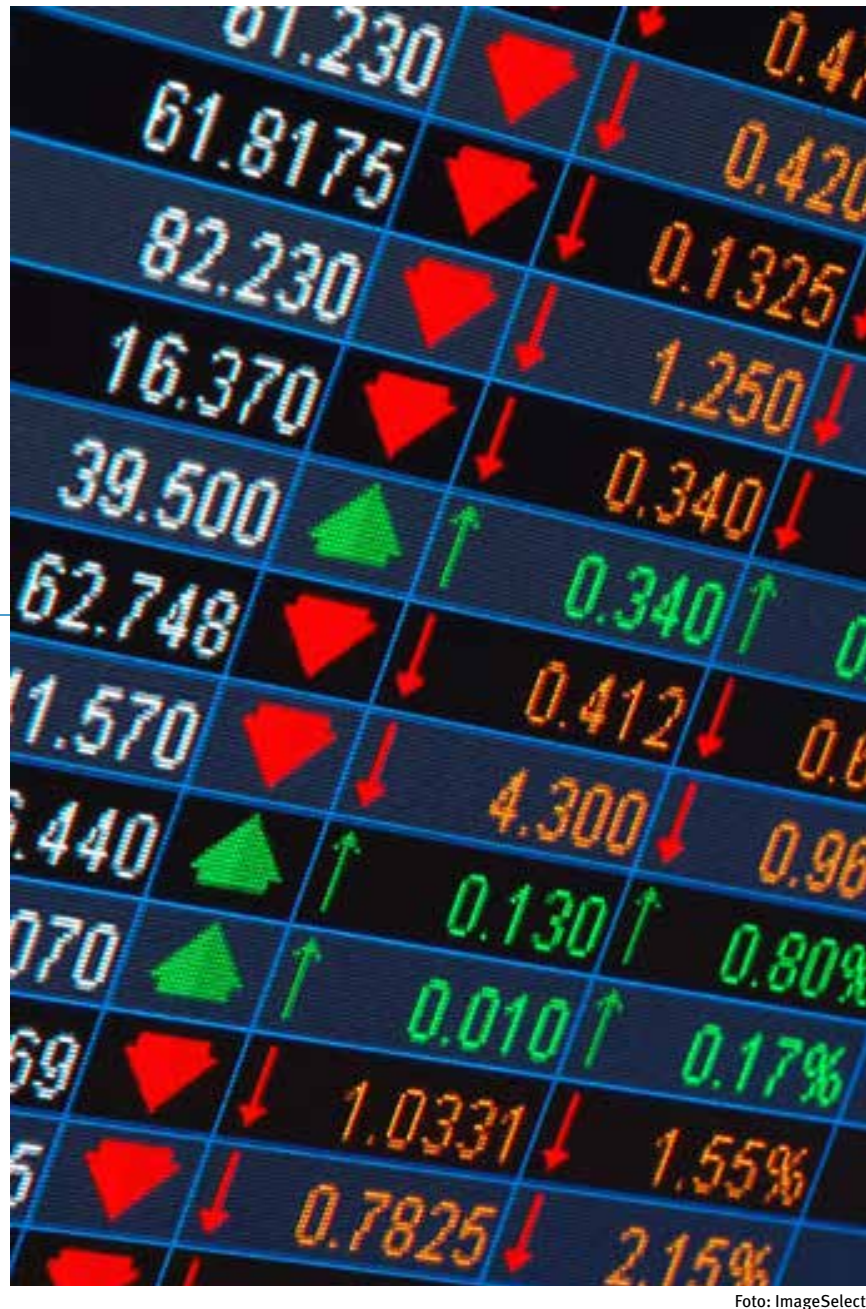

Foto: ImageSelec 


\section{Interest rate development}

In the recent 15 years, the interest rate has decreased in the Nordic countries - with Iceland as an exception. In 1990, the long-term interest rate, which is of importance to business investments and to the financing of dwellings, had a level of about 11 per cent in Denmark and Norway and one of about 13 per cent in Finland and Sweden. In 2005, the interest rate had dropped to about 3-4 per cent in Denmark, Finland, Norway and Sweden. After a few years with a slightly higher interest rate, it was in the beginning of 2009 again 3-4 per cent in these countries. The interest rates are in 2013 just around 2 per cent in the Nordic countries. This is close to a historically low interest rate.

Long term interest rates

Figure 13.10

\section{Långfristig ränta}

14

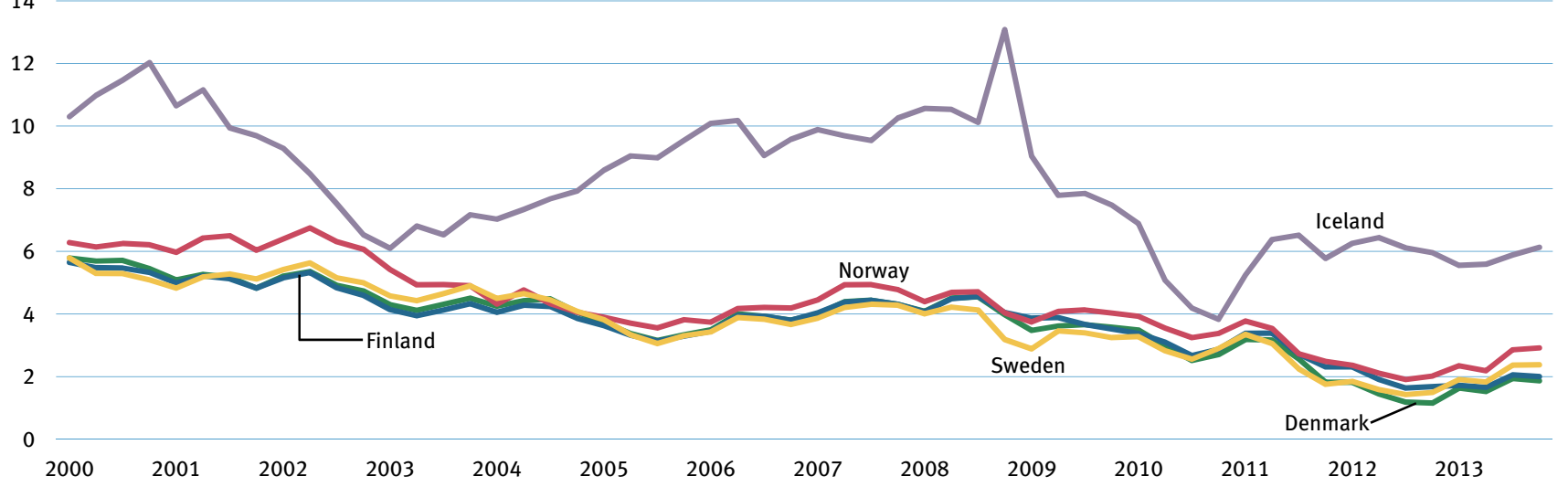

Iceland is the exception, and here the interest rate of nonindexed 5-year bonds reached its lowest level of 6 per cent already in 2003. Since 2003, the Icelandic interest rates moved upwards as a result of the financial crisis in Iceland. The interest rate was as high as 13.1 per cent in the fourth quarter of 2008. Since the beginning of 2009 the interest rate has fallen but still fluctuated and by the end of 2013, the Icelandic interest rate was close to 6 per cent - still well above the rest of the Nordic countries.

Sharos

Sharre: $O E C D$ Main Economic Indicators.
Rånteutvecklingen

Räntan har de senaste 15 åren fallit i de nordiska länderna med undantag för Island. Den långa räntan, som är väsentlig för näringslivets investeringar och för finansiering av bostäder, låg 1990 på en nivå omkring 11 procent i Danmark och Norge samt på omkring 13 procent i Finland och Sverige. År 2005 hade räntan fallit till 3-4 procent i Danmark, Finland, Norge och Sverige. Under de senaste åren har räntan stigit något, men i början av 2009 var den igen ungefär 3-4 procent i dessa länder. Räntorna har fortsatt att falla och är 2013 just kring 2 procent i de nordiska länderna. Det är nära en historiskt låg ränta.

Island är undantaget, där räntan för icke-indexerade 5-års obligationer nådde sin lägsta punkt på 6 procent redan 2003. Sedan 2003 har den isländska räntan rört sig uppåt till följd av den finansiella krisen på Island. Räntan var så hög som 13,1 procent under det fjärde kvartalet 2008. Sedan början av 2009 har räntan fallit men har fortfarande varierat och i slutet av 2013 var den isländska räntan nära 6 procent - fortfarande högre än $\mathrm{i}$ övriga Norden. 


\section{Agriculture, forestry and fishery Jordbruk, skogsbruk och fiske}

The primary sector comprising agriculture, forestry and fishery only accounts for a small part of total employment in the Nordic countries: from 2.1 per cent of employment in Sweden to 5.9 per cent of employment in Iceland. However, the sector indirectly forms the basis for a considerable part of production and employment. This is partly due to the fact that products from agriculture, forestry and fishery are used as raw materials in manufacturing and in other industries. And partly due to the fact that the capital-intensive primary sector requires many goods and services from other sectors, for example agricultural machinery, wood-cutting equipment, fishing vessels etc., as well as maintenance and services incidental to this machinery and equipment.

The primary sector also - both directly and indirectly - accounts for substantial exports in the Nordic countries. For example, two-thirds of all Danish agricultural products are exported. In Sweden and Finland - and to a smaller extent in Norway - forestry and the associated industries - wood industry and paper industry - account for a considerable share of total exports. In Norway, fishery plays a major role, and in Iceland, the Faroe Islands and Greenland fishery is by far the dominant industry, both with respect to production and exports.
Basnäringarna, jordbruk, skogsbruk och fiske, står i dag för en anspråkslös del av den samlade sysselsättningen i de nordiska länderna: från 2,1 procent i Sverige till 5,9 procent på Island. Indirekt utgör emellertid dessa näringar grunden för en mycket betydande produktion och sysselsättning. Dels därför att produkterna från jordbruk, skogsbruk och fiske ingår som råvaror i industrin och andra näringar. Och dels därför att basnäringarna, som är mycket kapitalkrävande, har behov av många varor från andra näringsgrenar, t.ex. lantbruksmaskiner, skogsmaskiner, fiskebåtar m.m. samt underhåll och service för all denna utrustning.

Basnäringarna svarar också, både direkt och indirekt, för en ansenlig export i Norden. I Danmark exporterar jordbruket två tredjedelar av sin produktion till utlandet. I Sverige och Finland, samt i mindre omfattning i Norge, är det skogsbruket och de anknutna näringsgrenarna, trä- och pappersindustri, som utgör en betydande del av den samlade exporten. I Norge spelar fisket en betydande roll och på Island, Färöarna och Grönland är det den helt dominerande näringen, såväl när det gäller produktion som export.

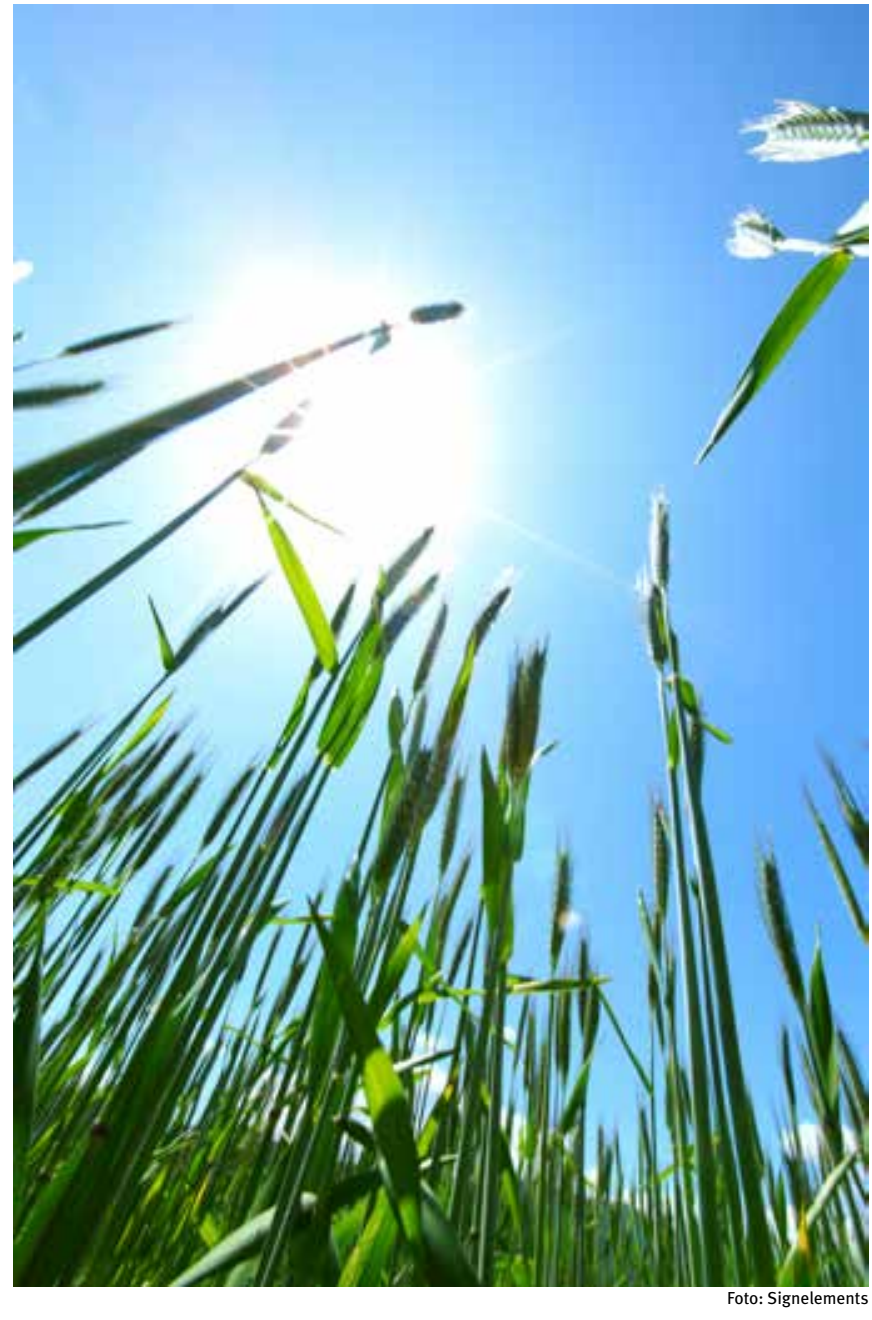

Foto: Signelements 


\section{Agriculture}

The primary agricultural areas in the Nordic countries are found in Denmark, southern Sweden and a belt extending from southwestern Finland through central Sweden. Agriculture in the

Nordic countries is characterized by a high degree of regulation - previously pursuant to national law, now pursuant to EU regulations, as the three main agricultural countries in the North, Denmark, Finland and Sweden, are members of the European Union.

For many years, the structural development has been moving towards fewer and larger holdings. In the Nordic countries, arable land is used for two main purposes: food production or the production of fodder for animals. In both Denmark and Finland more than half of the arable land ( 55 and 53 per cent respectively) is used for grain production - some for direct human consumption, some for animal consumption. In Sweden, 38 per cent of the arable land is used for grain production and in Norway 35 per cent. In the other Nordic countries, hay and fodder production predominate. Barley and wheat are the main grains in all the Nordic countries. In Finland, Åland, Norway and Sweden, oats also play a major role.
Jordbruk

De huvudsakliga jordbruksområdena i de nordiska länderna finns i Danmark, i södra Sverige och i ett bälte som sträcker sig från sydvästra Finland genom centrala Sverige. Jordbruket i de nordiska länderna kännetecknas av hård reglering - tidigare på grund av inhemska lagar, nu på grund av EU-reglering, eftersom de tre viktigaste jordbruksländerna i Norden, d.v.s. Danmark, Finland och Sverige, är medlemmar i den Europeiska unionen.

Under många år har strukturförändringen rört sig mot färre och större jordbruksföretag. I de nordiska länderna används åkermarken för produktion av livsmedel och djurfoder. I både Danmark och Finland används mer än hälften (55 respektive 53 procent) av åkermarken till spannmåls produktion - dels för direkt konsumtion av människor, dels till djurfoder. I Sverige brukas 38 procent av åkermarken också i första hand för spannmålsproduktion och i Norge 35 procent. I de andra nordiska länderna dominerar hö- och foderproduktionen. Korn och vete är huvudgrödorna i alla nordiska länder. I Finland, Norge, Sverige och på Åland spelar även havre en stor roll.

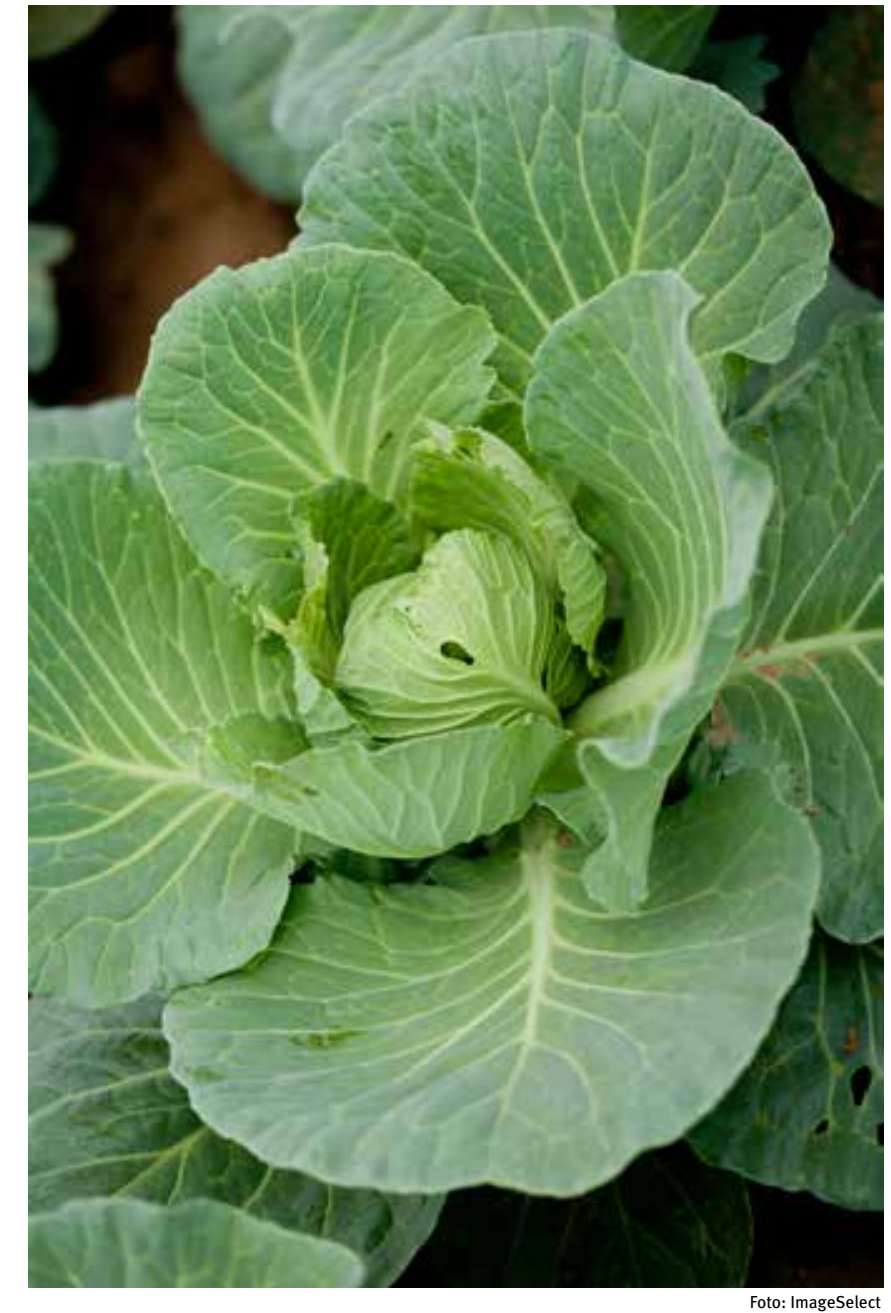

Foto: ImageSelect 


\begin{tabular}{|c|c|c|c|c|c|c|c|}
\hline & Denmark & Finland & Åland & Iceland & Norway & Sweden & \\
\hline 1000 tonnes & & & & & & & 1000 ton \\
\hline Crops & & & & & & & Grödor \\
\hline Potatoes & 1646 & 622 & 17 & 6 & 320 & 806 & Potatis \\
\hline Sugar beets & 1994 & 480 & 0 & - & .. & 2326 & Sockerbetor \\
\hline Fodder beets & 335 & .. & 0 & & & & Foderbetor \\
\hline Ley and other fodder crops & 25114 & 7371 & .. & 366 & 2409 & 4873 & Vall och andra foderväxter \\
\hline Oleiferous plants & 688 & 80 & 0 & - & 7 & 453 & Oljeväxter \\
\hline Grain & & & & & & & Spannmål \\
\hline Total & 9085 & 4063 & 15 & 6 & 913 & 4533 & Totalt \\
\hline Wheat & 3997 & 869 & 5 & - & 199 & 1869 & Vete \\
\hline Rye & 527 & 26 & 0 & - & 11 & 142 & Råg \\
\hline Barley & 3997 & 1904 & 4 & 6 & 480 & 1862 & Korn \\
\hline Oats & 313 & 1197 & 6 & - & 214 & 852 & Havre \\
\hline Mixed grain & 251 & 67 & - & . & .. & 96 & Blandsäd \\
\hline
\end{tabular}

Agriculture, forestry and fishery

Jordbruk, skogsbruk och fiske

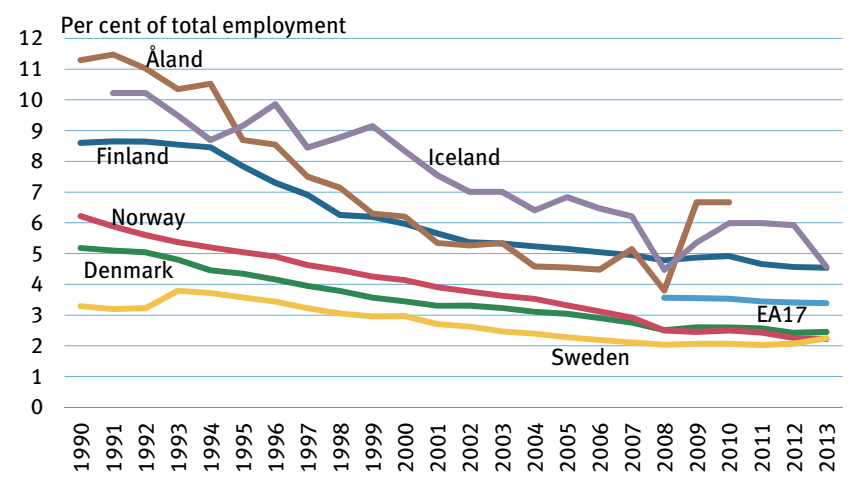
$\square \mathrm{NaaCO} 8$ Source: Eurostat and national statistical institutes.

Figure 14.1

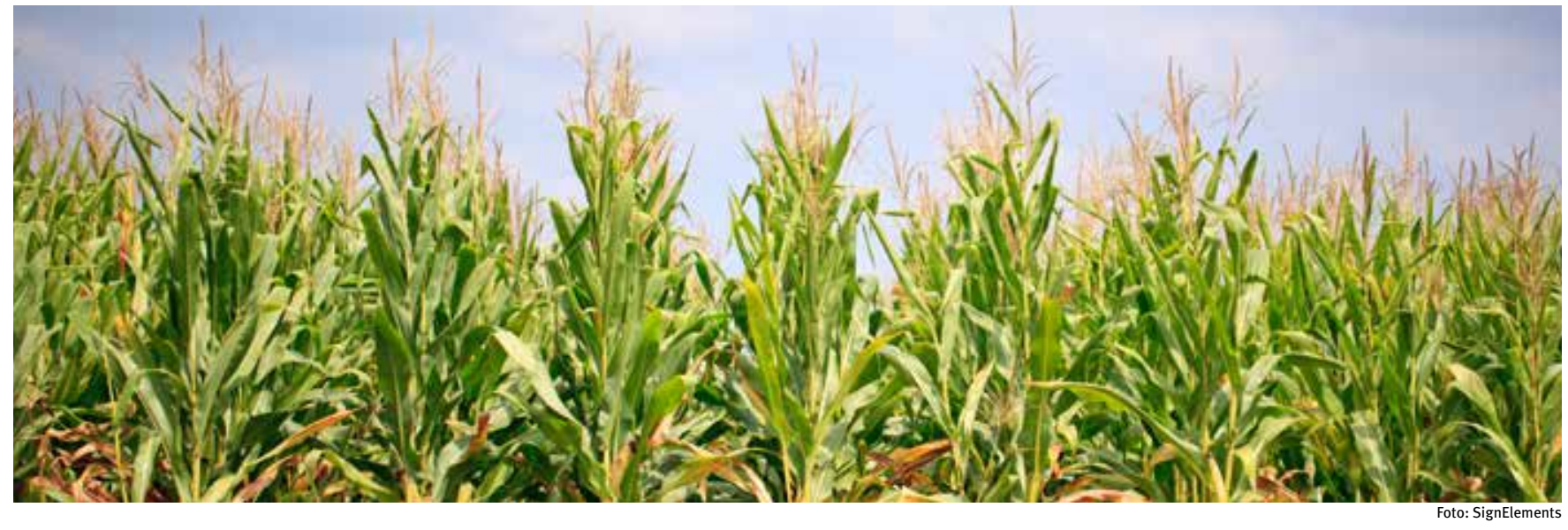




\section{Forestry}

The forest is a major resource in Finland and Sweden and, to a lesser extent, in Norway. It is only a very limited resource in Denmark. Greenland and the Faroe Islands have no natural forests because of the climate, but they do have smaller planted forests.

There is a considerable production of wood for industrial use in Finland and Sweden. For example, Finland and Sweden together represent 12.8 per cent of the world production of wood pulp, which is a major export item for these two countries.

\section{Skogsbruk}

Skogen är en stor resurs i Finland och Sverige och, i mindre utsträckning, i Norge. I Danmark är skogen endast en begränsad resurs. Grönland och Färöarna har inga naturliga skogar på grund av klimatet, men de har mindre planterade skogar.

Det finns en avsevärd produktion av virke för industribruk, särskilt i Finland och Sverige. Exempelvis står Finland och Sverige tillsammans för 12,8 procent av världsproduktionen av pappersmassa som är en stor exportprodukt för dessa två länder.

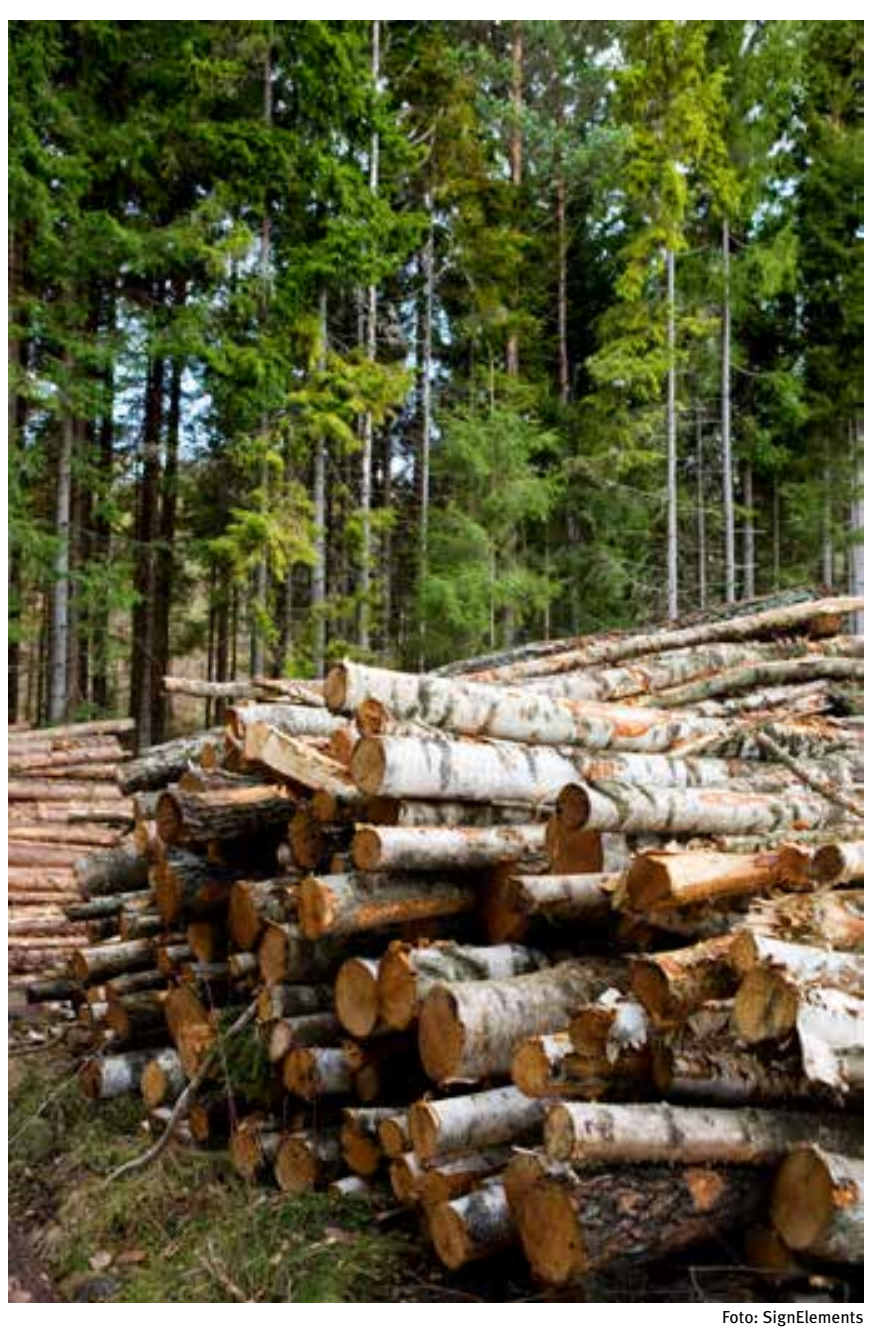

1000 cubic meter

Industrial roundwood

Saw logs and veneer logs

Wood-based panels

Denmark

\section{Finland}

Norway

1000 tonnes

Wood pulp

Paper and paperboard

Per cent of world production

Industrial roundwood

Saw logs and veneer logs

Wood pulp

\begin{tabular}{|c|c|c|c|c|}
\hline & & & & 1000 kubikmeter \\
\hline 1468 & 44614 & 8787 & 63000 & Industriellt rundvirke \\
\hline 779 & 19322 & 4460 & 32300 & Sågtimmer och fanerstock \\
\hline \multirow[t]{2}{*}{475} & 1273 & 482 & 754 & Träpanel \\
\hline & & & & 1000 ton \\
\hline 5 & 10440 & 1389 & 12394 & Pappersmassa \\
\hline \multirow[t]{2}{*}{422} & 10696 & 1198 & 11416 & Papper och papp \\
\hline & & & & Procent av världsproduktionen \\
\hline 0.1 & 2.7 & 0.5 & 3.8 & Industriellt rundvirke \\
\hline 0.1 & 2.0 & 0.5 & 3.4 & Sågtimmer och fanerstock \\
\hline 0.2 & 0.4 & 0.2 & 0.3 & Träpanel \\
\hline & 6.0 & 0.8 & 7.1 & Pappersmassa \\
\hline 0.1 & 2.7 & 0.3 & 2.9 & Papper och papp \\
\hline
\end{tabular}

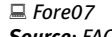




\section{Fishery}

In the three largest Nordic fishing nations, Denmark, Iceland and Norway, codfish and herring for consumption dominate the catch. Mackerel has always been an important fish for consumption in Norway. In Norway and Iceland, a large quantity of capelin is caught, which is both used for consumption and as raw material for the oil and fish meal industry. In Denmark, it is mainly sand eel and sprat that are used in the oil and fish meal industry.

For the Faroe Islands, Greenland and Iceland, fishery is the hub of the economy, but fishery also has a measurable impact on the national budget in Denmark and Norway. In the Faroe Islands almost 89 per cent of the export value stems from fishing and in Greenland 63 per cent. In Iceland, the percentage is close 39 and, in Denmark and Norway respectively, about 3-4 per cent and 6-7 per cent. Cod is the most valuable and important catch for Denmark, Iceland and Norway.

Fish farming is especially important in Norway, where the production of salmon is predominant. Rainbow trout is farmed in all the Nordic countries except in Greenland. Eels in greater volumes are only farmed in Denmark.
Fiske

I de tre största nordiska fiskenationerna, Danmark, Island och Norge, domineras fångsten av torsk och sill för konsumtion. Makrill har alltid varit en viktig fisk för konsumtion i Norge. Norge och Island fångar en stor kvantitet lodda, som både används för konsumtion och som råmaterial i olje- och fisk mjölsindustrin. I Danmark är det huvudsakligen tobis och skarpsill som används i olje- och fiskmjölsindustrin.

För Färöarna, Grönland och Island är fisket basen i ekonomin. Fisket har också en mätbar inverkan på den nationella budgeten i Danmark och Norge. På Färöarna kommer nästan 89 procent av exportvärdet från fisket och på Grönland nära 63 procent. För Island är procenttalet nära 39 procent och i Danmark och Norge mellan 3-4 respektive 6-7 procent. Torsk är den mest värdefulla och viktiga fångsten för Danmark, Island och Norge.

Fiskodling är särskilt viktigt i Norge, där laxodling dominerar. Regnbågslax odlas i alla de nordiska länderna utom på Grönland, ål dock i större volymer endast i Danmark.

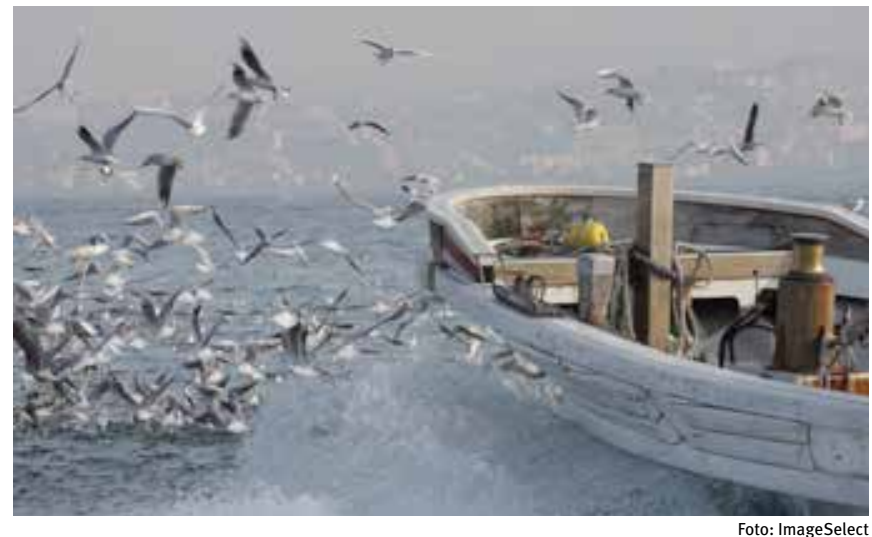

Value of catches of fish Figure 14.2 Värde av fiskefängst

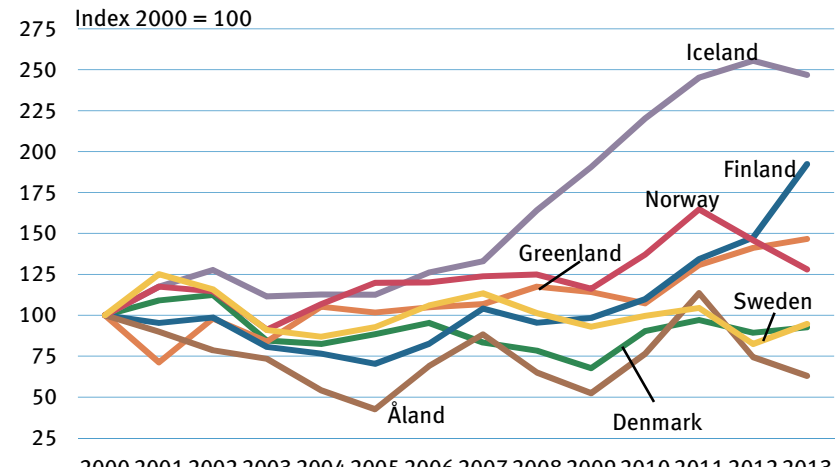

20002001200220032004200520062007200820092010201120122013 므 Fisho2

Source: Danish Directorate of Fisheries, Greenland Fisheries Licence Control Authority, Statistics Faroe Islands, Finnish Game and Fisheries Research Institute, Statistics Aland, Fisheries
Association of I celand, Norwegian Directorate of Fisheries and Swedish Board of Fisheries. 
Årliga kommersiella fångster av fisk, värde och mängd

\begin{tabular}{|c|c|c|c|c|c|c|c|c|c|}
\hline & Denmark & $\begin{array}{r}\text { Faroe } \\
\text { Islands }\end{array}$ & Greenland & Finland & Åland & Iceland & Norway & Sweden & \\
\hline Million euro & & & & & & & & & Milj. euro \\
\hline Total & 405.8 & 284.0 & 114.0 & 46.6 & 2.1 & 927.0 & 1595.4 & 104.9 & Totalt \\
\hline Flat fishes & 50.2 & .. & 50.3 & 0.1 & 0.0 & 61.2 & 44.4 & 2.1 & Plattfisk \\
\hline Codfishes & 66.2 & .. & 8.5 & 0.5 & 0.5 & 465.9 & 851.4 & 13.9 & Torskfisk \\
\hline Other sea water fishes & 212.2 & .. & 6.7 & 36.6 & 0.8 & 372.0 & 609.5 & 60.4 & Annan havsfisk \\
\hline Crustaceans and molluscs & 72.1 & .. & 48.5 & .. & 0.0 & 27.8 & 90.1 & 25.3 & Kräftdjur och blötdjur \\
\hline Freshwater fishes & 5.0 & .. & 0.1 & 9.4 & 0.6 & 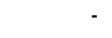 & .. & 3.1 & Sötvattensfisk \\
\hline 1000 tonnes & & & & & & & & & 1000 ton \\
\hline Total & 668.4 & 487.2 & 100.7 & 138.4 & 4.3 & 1339.9 & 2081.2 & 180.5 & Totalt \\
\hline Flat fishes & 30.6 & 4.3 & 23.4 & 0.0 & 0.0 & 25.2 & 16.2 & 1.1 & Plattfisk \\
\hline Codfishes & 73.8 & 175.3 & 14.9 & 0.5 & 0.3 & 465.0 & 995.5 & 10.4 & Torskfisk \\
\hline Other sea water fishes & 507.3 & 297.9 & 15.5 & 132.7 & 3.8 & 835.4 & 907.1 & 164.2 & Annan havsfisk \\
\hline Crustaceans and molluscs & 55.9 & 9.7 & 46.9 & .. & .. & 14.3 & 162.1 & 2.7 & Kräftdjur och blötdjur \\
\hline Freshwater fishes & 0.8 & .. & 0.0 & 5.2 & 0.2 & 0.0 & 0.2 & 2.2 & Sötvattensfisk \\
\hline
\end{tabular}

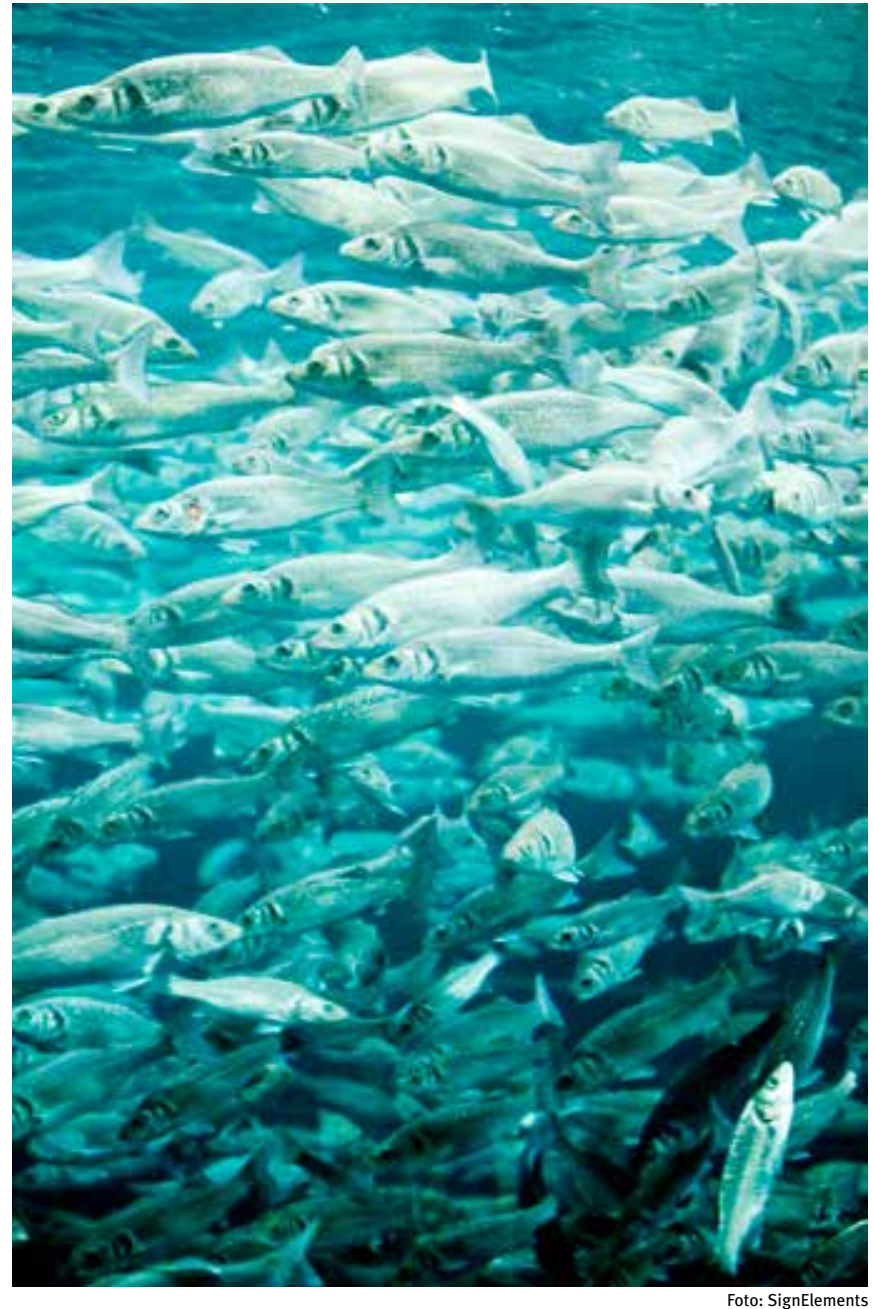

Source: Danish Directorate of Fisheries, Greenland Fisheries Licence Control Authority, Statistics Faroe Islands, Finnish Game and Fisheries Research Institute,

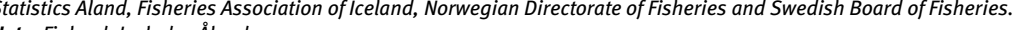

Not: Finland: Inkluderar Aland. 


\section{Science and technology Vetenskap och teknologi}

Research and development (R\&D) comprises creative work undertaken on a systematic basis in order to increase the stock of knowledge, including knowledge of man, culture and society, and the use of this stock of knowledge to devise new applications. The purpose of statistics on R\&D is to estimate resources devoted to this activity in all sectors - in particular, science and industry. In addition the statistics also try to measure the output from investments in R\&D.

New information and communication technologies (ICT) started to enter into people's everyday life in the latter part of the 1990s. Mobile phones, computers and the Internet opened up new channels of communication. In several studies it has been shown that the Nordic countries have been in the forefront of the ICT penetration and use. Almost everybody now has access to the Internet - both enterprises and households.
Forskning och utveckling (FoU) omfattar skapande arbete som bedrivs på ett systematiskt sätt för att höja den totala kunskapsnivån, bland annat kunskap om människan, kulturen och samhället, samt användning av dessa kunskaper till nya tillämpningar. Syftet med statistik över forskning och utveckling (FoU) är att uppskatta de resurser som avsätts till dessa aktiviteter i alla sektorer, i synnerhet vetenskap och industri. Dessutom försöker statistiken mäta vad som kommer ut av investeringarna i FoU.

Under den senare delen av 1990-talet började ny informations- och kommunikationsteknologi (IKT) träda in i människors vardagsliv. Mobiltelefoner, datorer och Internet öppnade nya kanaler för kommunikation. I flera studier har man visat att de nordiska länderna har varit ledande i användning av IKT. Nästan alla har nu tillgång till Internet - både företag och hushåll.

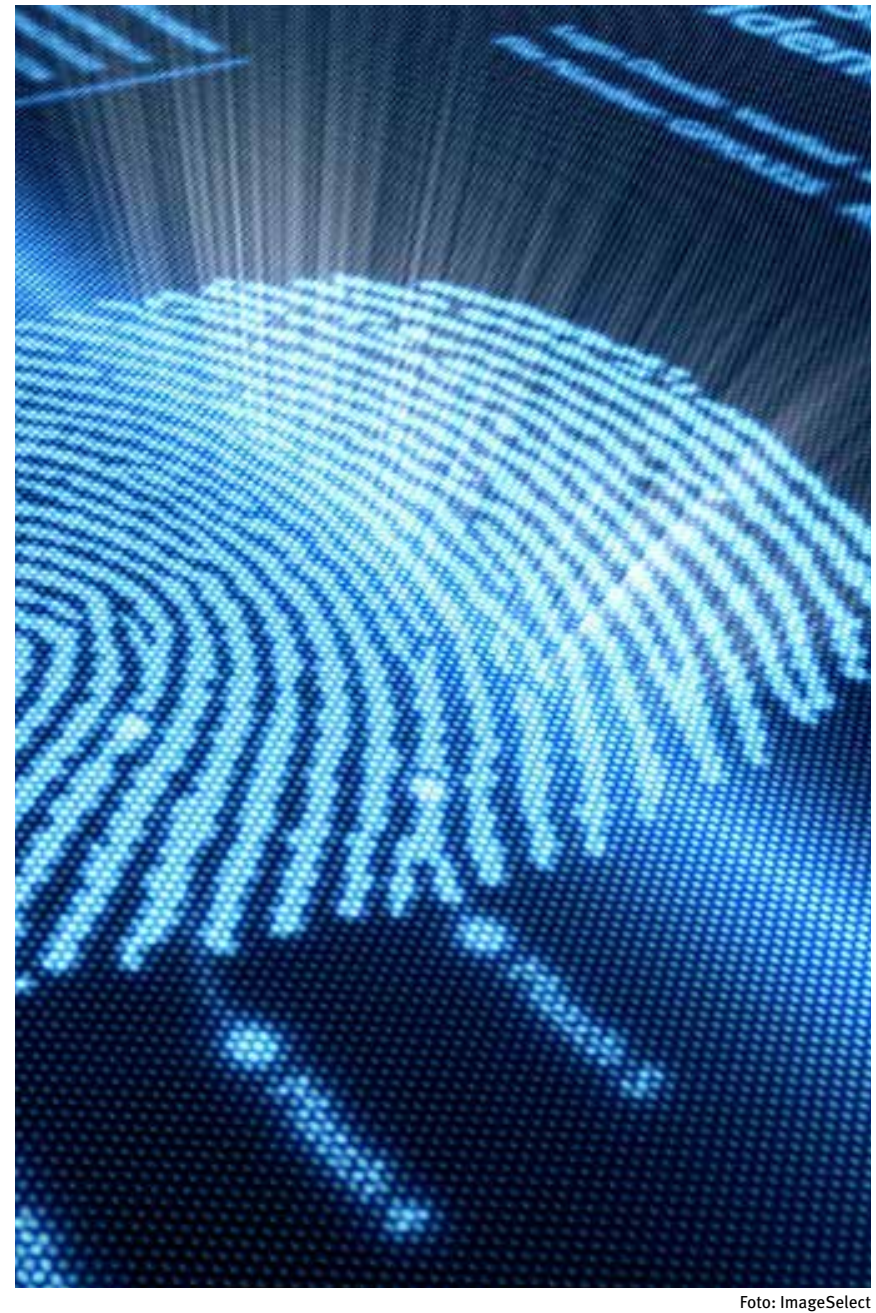

Foto: ImageSele 


\section{Research and development}

In relative terms, the Nordic countries spend more resources on R\&D than other West European countries. The 27 countries in the EU spend 2.1 per cent of their gross domestic product (GDP) on research and development, while Finland spends 3.6 per cent, Sweden 3.4 per cent, Denmark around 3.0 per cent and Iceland 2.4 per cent.

Only Norway is below the EU27 average with 1.7 per cent of GDP. On the other hand, Norway's GDP is extraordinarily high due to the country's oil and gas revenue, and if the Norwegian

R\&D staff, full time equivalent. 2012 Figure 15.1 FoU-personal

Per cent of total employment

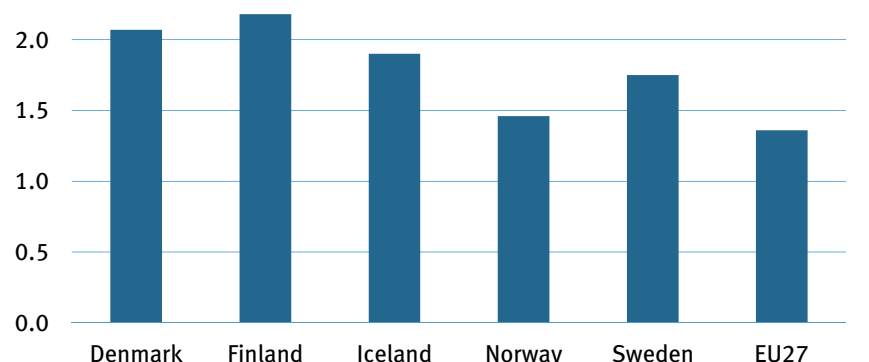

Denmark Finland Iceland Norway Sweden EU27

Rede04

Source: National statistical institutes and Eurostat.

Note: Iceland: 2011 data. EU27: The 27 member states of the European Union as per

1 January 2013.

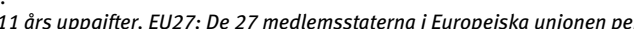

1 januari 2013.
R\&D expenses are calculated as euro per person, they are higher than the R\&D expenses per person in EU27. While the R\&D expenses in Norway have constituted an unchanged proportion of GDP since the mid-1990s, the R\&D expenses in the other Nordic countries have typically increased.

Forskning och utveckling

De nordiska länderna använder relativt sett mera resurser på FoU än de övriga länderna i Västeuropa. De 27 länderna i EU använder 2,1 procent av bruttonationalprodukten (BNP) till forskning och utveckling, medan Finland använder 3,6 procent, Sverige 3,4 procent, Danmark kring 3,0 procent och Island 2,4 procent.

Bara Norge ligger med sina FoU-utgifter på 1,7 procent av BNP under EU27-genomsnittet. Å andra sidan är Norges BNP tack vare landets olje- och gasintäkter ovanligt hög, och mäter man i stället de norska FoU-utgifterna i euro per capita, är de högre än FoU-utgifterna per capita i EU27. Medan FoU-utgifterna i Norge sedan mitten av 90-talet har legat på en oförändrad andel av BNP, har FoU-utgifterna i de andra nordiska länderna i allmänhet ökat.

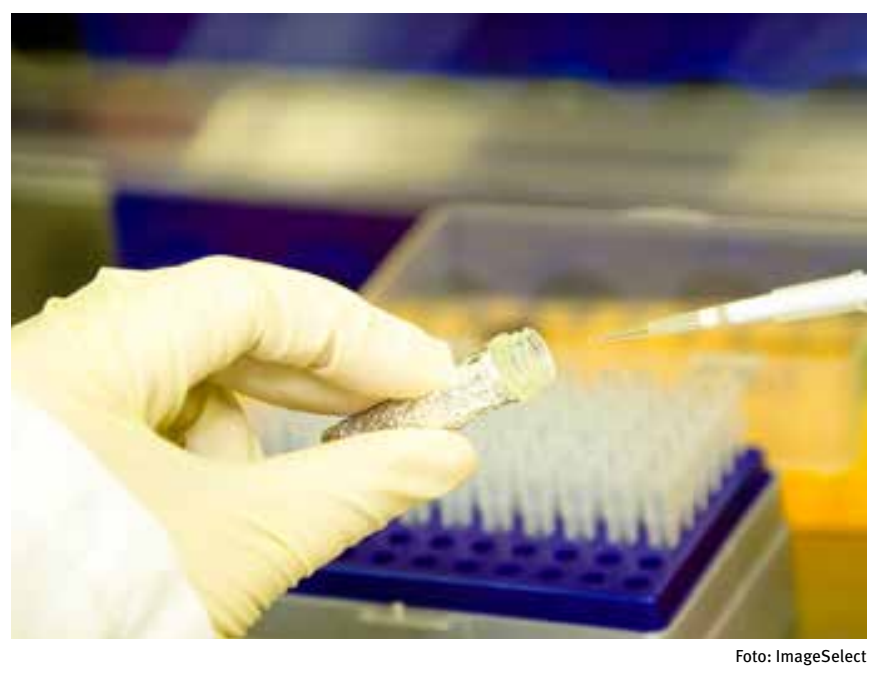

Total R\&D expenditure

Totala FoU-utgifter

$2005 \quad 2007 \quad 2009 \quad 2012$

\begin{tabular}{lllllr}
\hline $\begin{array}{l}\text { Per cent } \\
\text { of GDP }\end{array}$ & & & & & $\begin{array}{r}\text { Procent } \\
\text { av } B N P\end{array}$ \\
Denmark & 2.46 & 2.58 & 3.16 & 2.98 & $\begin{array}{r}\text { Danmark } \\
\text { Finland }\end{array}$ \\
Iceland & 3.48 & 3.47 & 3.94 & 3.55 & Island \\
Norway & 2.77 & 2.68 & 3.11 & 2.40 & Norge \\
Sweden & 1.51 & 1.59 & 1.78 & 1.65 & Sverige \\
EU27 & 3.56 & 3.40 & 3.60 & 3.41 & EU27 \\
\hline
\end{tabular}

Rede01

Source: Eurostat.

Note: Iceland: 2012 data refer to 2011. EU27: The 27 member states of the European Union as per 1 January 2013.

Per 1land: 2012 avser 2011 års uppgifter. EU27: De 27 medlemsstaterna i Europeiska unionen per 1 januari 2013. 
Denmark Finland Iceland Norway Sweden

EU27

Million euro (PPS)

Total

$1824.7 \quad 1643.6$

87.0

Percent

Total

Exploration and exploitation of the
earth

Environment

Exploration and exploitation of space

Transport, telecommunication

and other infrastructure

Energy

Industrial production and technology

Health

Agriculture

Education

Culture, recreation, religion and

mass media

Political and social systems,

structures and processes

General research financed

from GUF

General research financed

from other sources than GUF

Defence

100.0

1973.

2473.4

88100.4

Milj. euro (PPS)

Totalt

Procent

$\begin{array}{rrrrrr}0.4 & 1.3 & 1.7 & 1.6 & 7.0 & 1.7 \\ 2.0 & 1.6 & 4.0 & 2.6 & 1.9 & 2.5 \\ 1.3 & 2.0 & . . & 2.3 & 2.1 & 5.8 \\ & & & & & \\ 0.6 & 1.7 & 1.7 & 1.8 & 4.5 & 2.8 \\ 4.1 & 9.4 & 0.6 & 3.0 & 4.9 & 4.6 \\ 8.0 & 19.0 & 1.0 & 8.3 & 1.1 & 10.6 \\ 11.4 & 5.2 & 4.8 & 15.8 & 1.3 & 7.1 \\ 3.0 & 4.8 & 14.9 & 7.4 & 1.6 & 3.2 \\ 3.9 & 0.1 & . . & 1.0 & 0.2 & 1.2 \\ & & . & & & \\ 1.6 & 0.5 & . . & 0.9 & 0.2 & 1.2 \\ & & & & & \\ 2.5 & 4.6 & 11.8 & 6.1 & 2.8 & 3.4 \\ & & & & & \\ 44.5 & 28.8 & 36.9 & 33.2 & 48.5 & 35.4 \\ 16.7 & 19.3 & 23.5 & 12.0 & 23.5 & 16.8 \\ 0.3 & 1.9 & 0.0 & 4.3 & 8.0 & 3.4\end{array}$

00.0

Totalt

1.7
2.5

Utforskning Transport, telekommunikation $\begin{array}{rr}2.8 & \text { och annan infrastruktur } \\ 4.6 & \text { Energi } \\ 0.6 & \text { Industriell produktion och teknologi }\end{array}$ $10.6 \quad$ Industriell produktion och teknologi
7.1
3.2 J.2 Jordbruk $1.2 \quad$ Kultur, rekreation, Utbildning Kultur, rekreation, religion och
massmedia Politiska och sociala system, strukturer
och processer

Allmän vetenskaplig forskning finansierad via GUF

Annan civil forskning finansierad genom andra källor än universitetsmedel
Försvar

믈ede11

Note: ")GUF: General University Funds. PPS: Purchasing Power Standards which eliminates the differences in price levels between the countries. Sweden and EU27: 2012 dato.

Ter 1 anuary 2013

Not: ${ }^{j}$ GUF: General University Funds (universitetsmedel). PPS: Purchasing Power Standards - Köpkraftspariteter som eliminerar skillnader i prisnivå mellan länderna. Sverige och EU27: 2012 års upp EU27: De 27 medlemsstaterna i Europeiska unionen per 1 januari 2013. class research initiative in climate, energy and the environment.

This top class research initiative is the largest single research and innovative initiative within the Council of Ministers and is now running in its fifth year.

The top class research initiative is a contribution from the Nordic countries to solve the global climate crisis, and the same time strengthen the Nordic region within research and innovation. The initiatives have their focus on the areas of climate and energy research, where the Nordic countries have common interests, and the Nordic countries can contribute with solutions internationally.

Klimat, energi och miljö i fokus

Under 2009 igångsatte Nordiska ministerrådet ett nordiskt toppforskningsinitiativ inom klimat, energi och miljö. Toppforskningsinitiativet är i dag den största enskilda forskningen och det mest nyskapande initiativet inom Nordiska ministerrådet och är nu inne på sitt femte år.

Genom toppforskningsinitiativet bidrar de nordiska länderna till att försöka lösa den globala klimatkrisen och samtidigt stärks Norden som region för forskning och innovationer. Satsningen fokuserar på de områden inom klimat- och energiforskning där de nordiska länderna har gemensamma intressen och där Norden kan bidra med lösningar internationellt. 


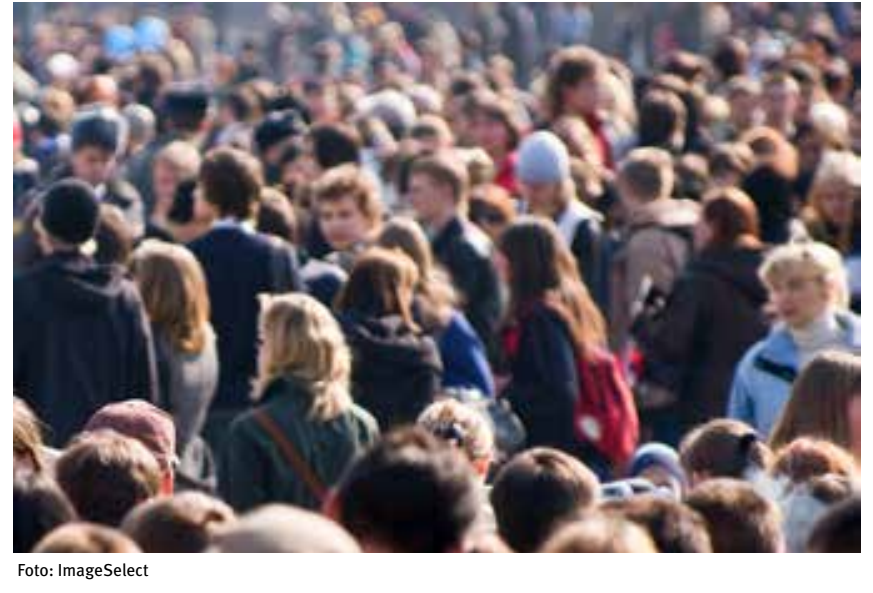

Research and development expenses

The major part of the expenses that the government spends on

R\&D is used by private enterprises in all the Nordic countries.

The rest of the R\&D activities take place at universities and

other institutions of higher education as well as in other public

institutions.

Government expenditure on $R \& D$ by performing sector. 2012 Offentliga sektorns FoU-utgifter efter spenderande sektor
FoU-utgifter

Den största delen av utgifterna, som den offentliga sektorn spenderar på FoU används av privata företag i alla de nordiska länderna. Övriga FoU-aktiviteter äger rum på universiteten och andra högre läroanstalter samt i offentlig regi i övrigt.

Figure 15.2

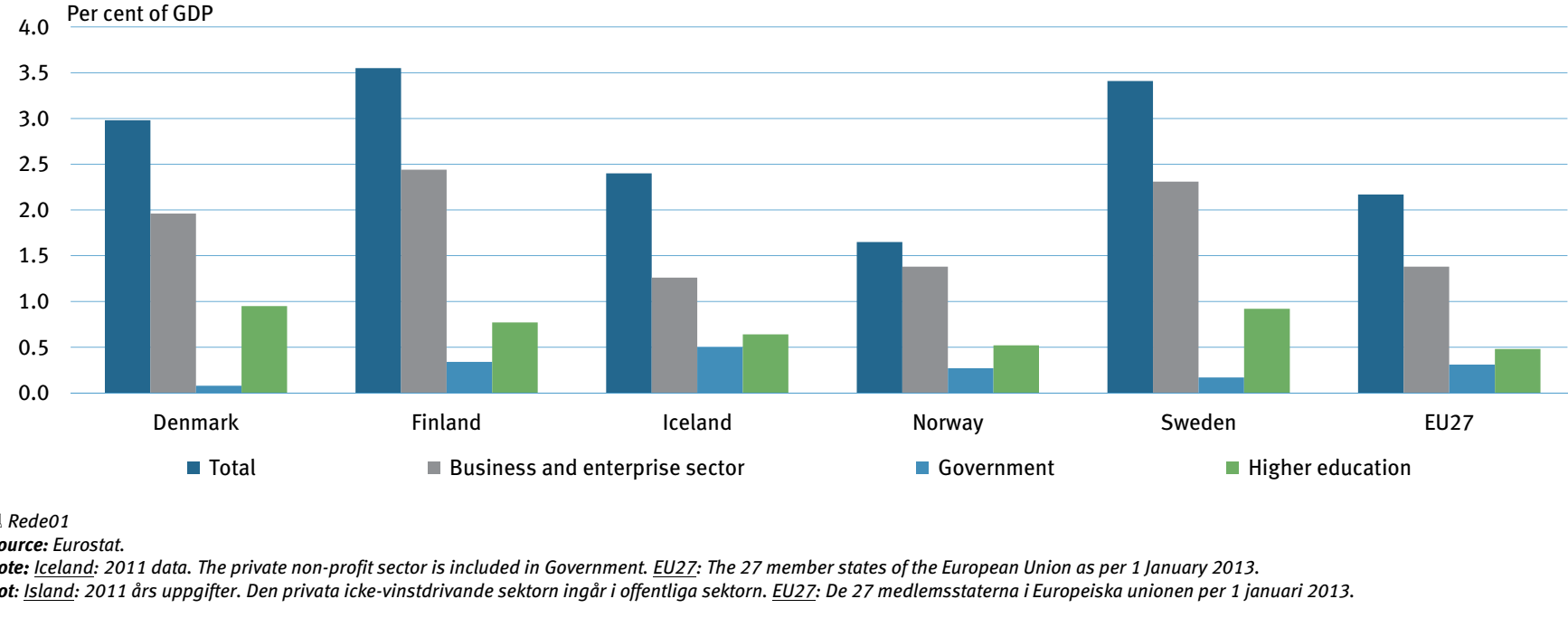

138 Science and technology · Vetenskap och teknologi 
Output from investments in R\&D

The number of patents and the number of $\mathrm{PhD}$ graduates give

an idea of the output of the investment in research and development, but do not by far give the full output-picture.

The number of patents shown here comprises direct European applications filed through the European Patent Organisation (EPO) and international applications (PCT) entering the European phase. Sweden both filed and received the highest number of patents among the Nordic countries.

Finland and Sweden have the highest numbers of $\mathrm{PhD}$ graduates. In all countries there are more male $\mathrm{PhD}$ graduates than female, setting aside Finland where the women have outnumbered the men.

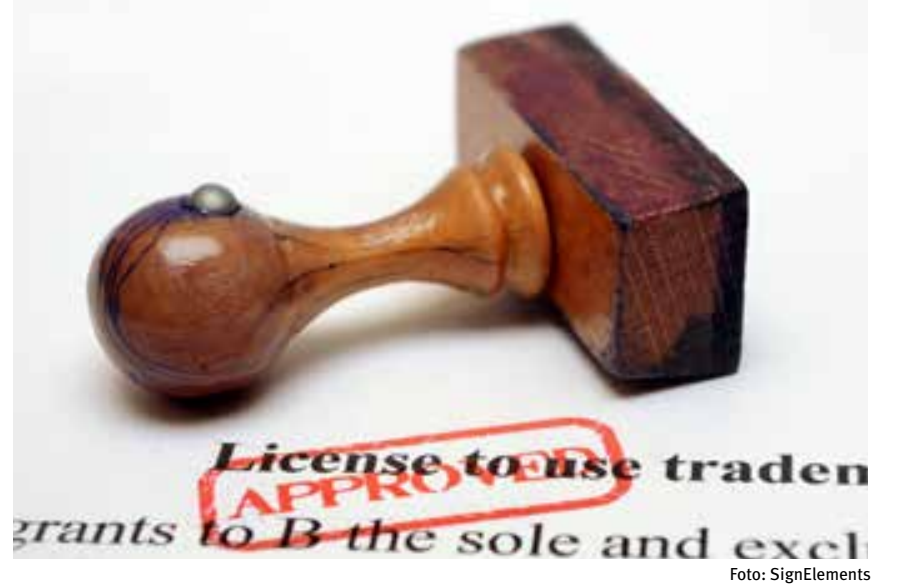

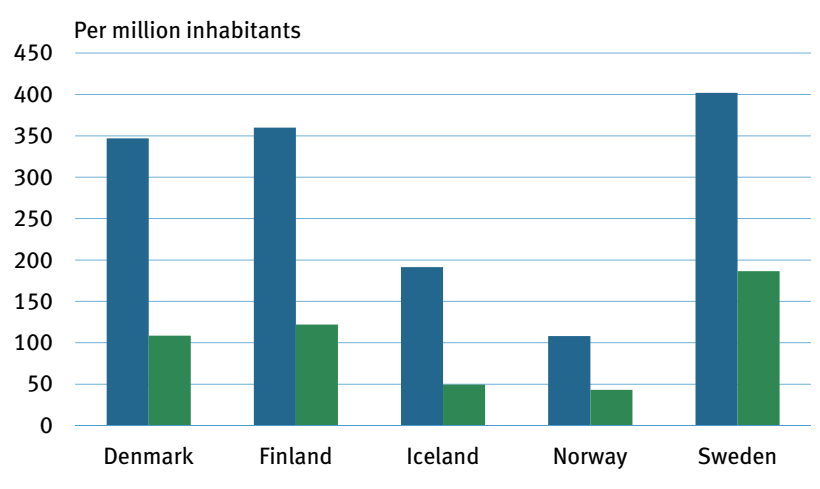

Denmark

Filed applications Granted patents

- Filed applications $\quad \square$ Granted patents

$$
\text { Source: Europeat }
$$

\section{Source: European Patent Office.}

PhD graduates. 2012

Filosofie doktorer

Figure 15.4

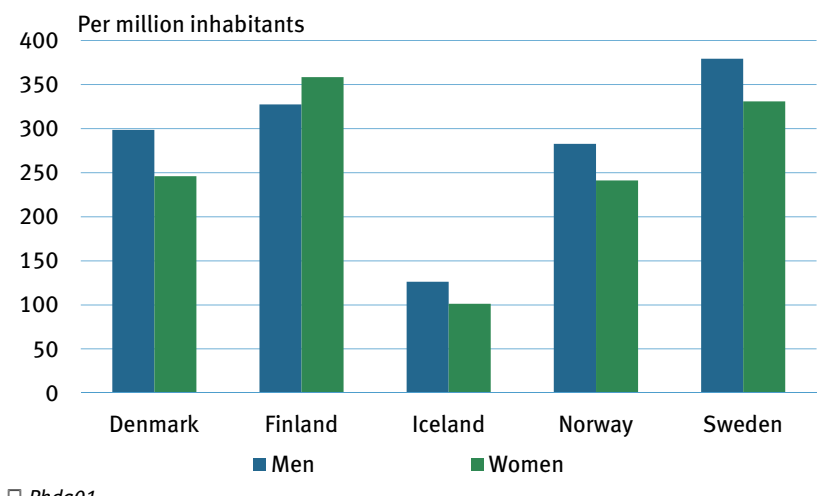

마 Phdg01
- Women
Resultat av investeringar i Fou

Antalet patent och antalet doktorer ger en bild av resultatet av det man investerar i forskning och utveckling, men de ger absolut inte hela bilden.

Antalet patent omfattar här europeiska ansökningar som lämnats direkt till den europeiska patentorganisationen (EPO) och internationella ansökningar (PCT) som är inne i den europeiska fasen. Sverige både sökte och fick det högsta antalet patent bland de nordiska länderna.

Finland och Sverige har det högsta antalet doktorer. I alla länder finns det flera manliga doktorer än kvinnliga utom i Finland, där kvinnorna är fler än männen.

Did you know that ... in 1960 there were 230 telephones per 1000 inhabitants in the Nordic countries. In 2013 there were 1453 mobile phone subscriptions per 1000 inhabitants.

Visste du att ... år 1960 fanns det 230 telefoner per 1000 invånare i de nordiska länderna. År 2013 fanns det 1453 mobiltelefonabonnemang per 1000 invånare. 


\section{Interaction with public authorities via the Internet}

The most frequent type of interaction with public administrations for individuals over the Internet is to obtain information. The level of interaction with the public authorities via the Internet is higher for both individuals and enterprises in all the Nordic countries compared to both EA17 and EU27. Enterprises generally have a higher interaction frequency than individuals.
Samverkan med myndigheter via Internet

Den vanligaste typen av interaktion privatpersoner har med

offentliga förvaltningar över Internet är att inhämta information.

Graden av samverkan med offentliga myndigheter via Internet är högre för både privatpersoner och företag i hela Norden jämfört

med både EA17 och EU27. Företagen har generellt en högre

interaktionsfrekvens än privatpersoner.
Interaction of enterprises with public authorities via the Internet. 2013 Företags samspel med offentliga myndigheter via Internet

98

96

94

92

90

88

86

84

82
Per cent of all enterprises

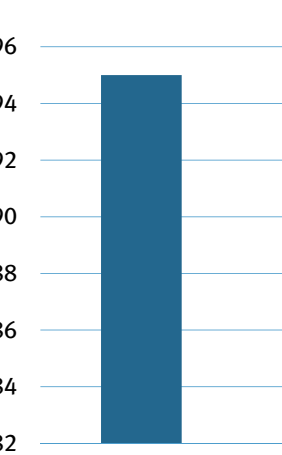

Denmark

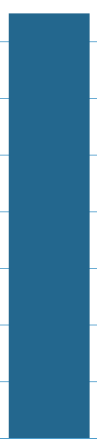

Finland

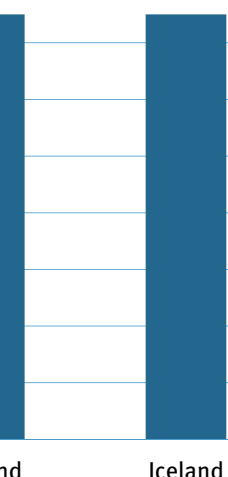

Iceland

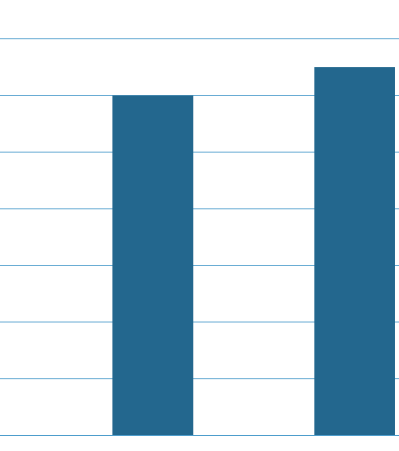

Norway
Figure 15.5

모ioio2

Note: Enterprises do not include the financial sector or enterprises with less than 10 employees. EU27: The 27 member states of the European Union as per 1 January 2013. Not: Företag inkluderar inte den finansiella sektorn eller företag med färre än 10 anställda. EU27: De 27 medlemsstaterna i Europeiska
unionen per 1 januari 2013 .
Interaction of individuals with public authorities via the Internet. 2013

Figure 15.6 Privatpersoners samspel med offentliga myndigheter via Internet

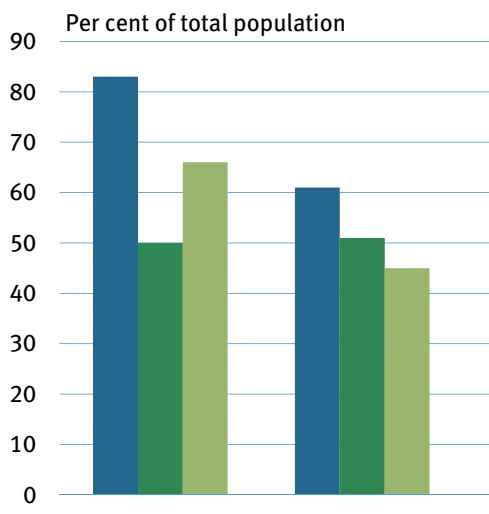

Denmark
Finland

obtaining information

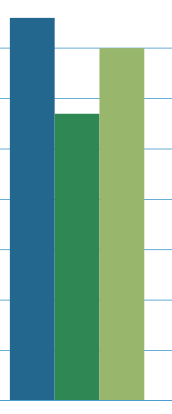

Iceland n Obtaining forms

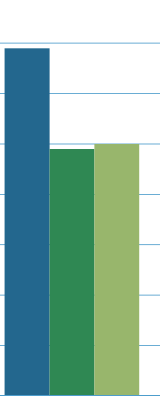

Norway

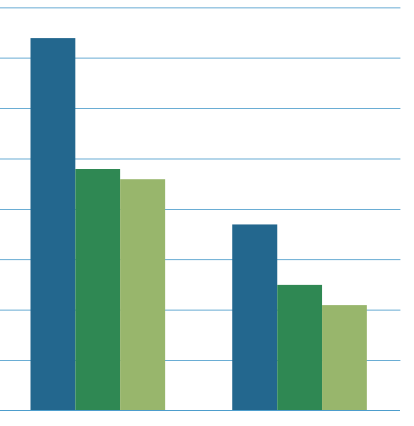

Sweden EU27

믐igio1

Source: Eurostat.

:U27: The 27 member states of the European Union as per 1 lanuary 2013.

Not: EU27: De 27 medlemsstaterna i Europeiska unionen per 1 januari 2013. 


\section{Access to the Internet and homepages}

Iceland is in the lead when it comes to access to ICT and broadband at home. More than nine out of ten have access to the Internet and broadband access. In Finland, where the share is the lowest, 89 per cent have access to the Internet. The access to broadband is the lowest in Denmark and Sweden with 87 per cent.

Tillgång till Internet och hemsidor

Island är i täten när det gäller tillgång till IKT och bredband i hemmen. Mera än nio av tio har tillgång till dator och Internet. I Finland, som ligger lägst, har 89 procent tillgång till Internet. För tillgång till bredband ligger Danmark och Sverige lägst med 87 procent.

\section{The number of Internet users}

People between 16 and 74 in all the Nordic countries are more frequent Internet users than people in the EA or

EU27. From 92 per cent in Finland to 97 per cent in Norway are frequently on the Internet.

Anvåndning av Internet

Befolkningen mellan 16 och 74 år i alla de nordiska länderna använder Internet oftare än befolkningen i både EA och EU27. Från 92 procent i Finland till 97 procent i Norge använder Internet regelbundet.

\section{Tillgång till IKT hemma}

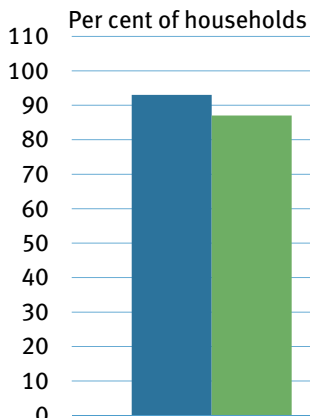

Denmark

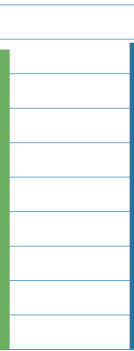

Finland
Internet access

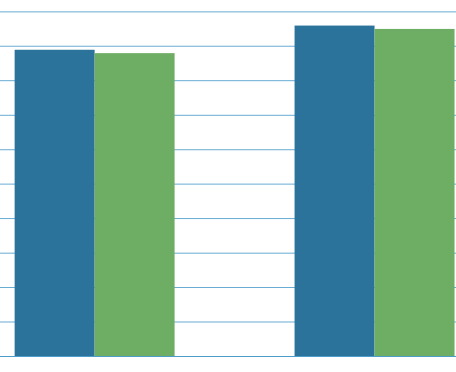

Iceland
믄 Infoo6

Source: Eurostat and national statistical institutes.

27: De 27 medlemsstaterna i Europeiska unionen per 1 januari 2013.

Internet use

Table 15.3

Användning av Internet

$\begin{array}{rlllll}\text { Denmark } & \text { Finland } & \text { Iceland } & \text { Norway } & \text { Sweden } & \text { EU27 }\end{array}$

Per cent of 16-74 years old

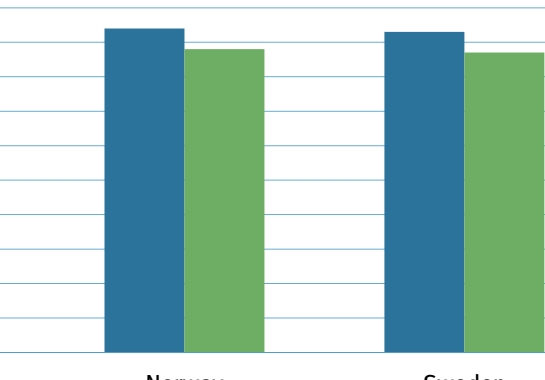

Norway
Sweden

- Broadband access

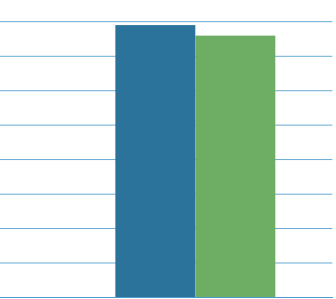

EU27 population

Within the last 3 months

\begin{tabular}{|c|c|c|c|c|c|c|c|}
\hline 2003 & 71 & 66 & 77 & 81 & 75 & 45 & 2003 \\
\hline 2013 & 95 & 92 & 95 & 97 & 95 & 76 & 2013 \\
\hline
\end{tabular}

At least once a week

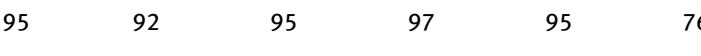

Åtminstone en gång i veckan

\begin{tabular}{llllllll}
2003 & 64 & 58 & 75 & 66 & 69 & 36 & 2003 \\
2013 & 91 & 89 & 92 & 95 & 93 & 72 & 2013 \\
\hline
\end{tabular}

Source: Eurostat.

Source: Eurostat.
Note: EU27: The 27 member states of the European Union as per 1 January 2013.

Not: EU27: De 27 medlemsstaterna i Europeiska unionen per 1 januari 2013. 


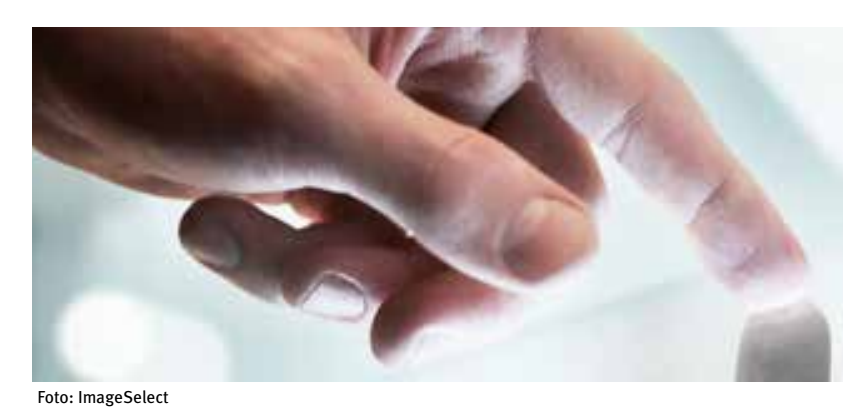

Mobile phone subscriptions Mobiltelefonabonnemang

Figure 15.8

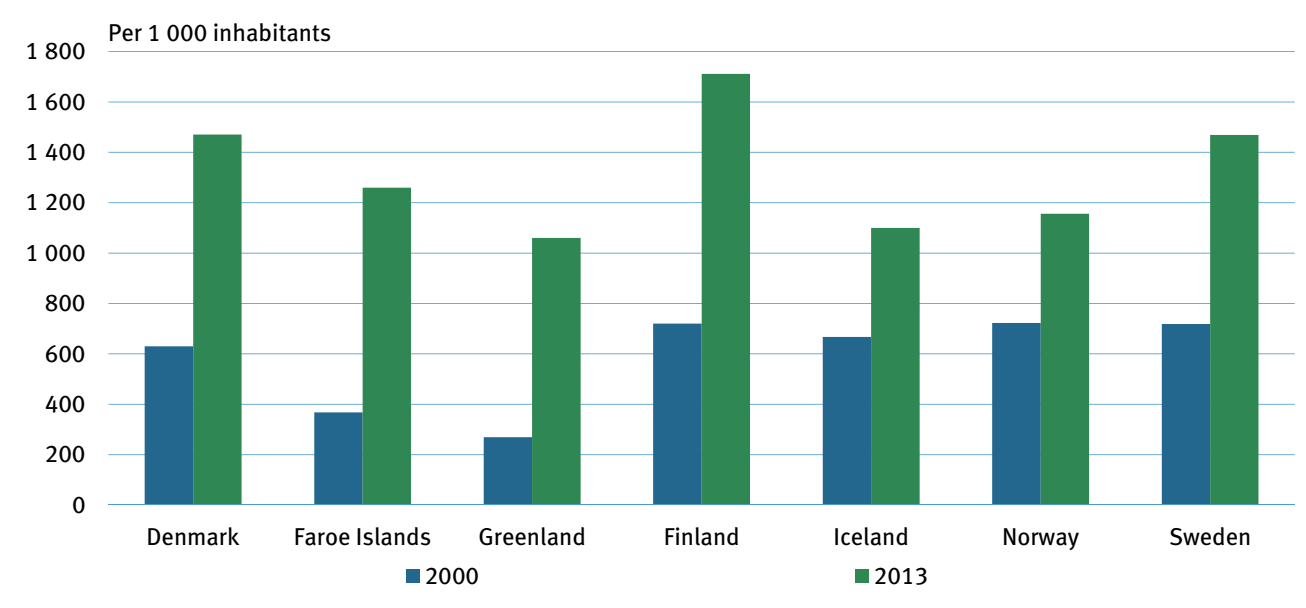

믄 Infoog

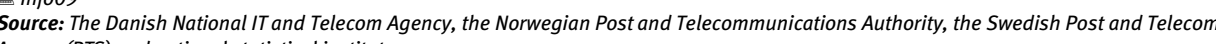
Agency (PTS) and national statistical institutes.
Internet purchases by individuals Köp via Internet av privatpersoner

Figure 15.9

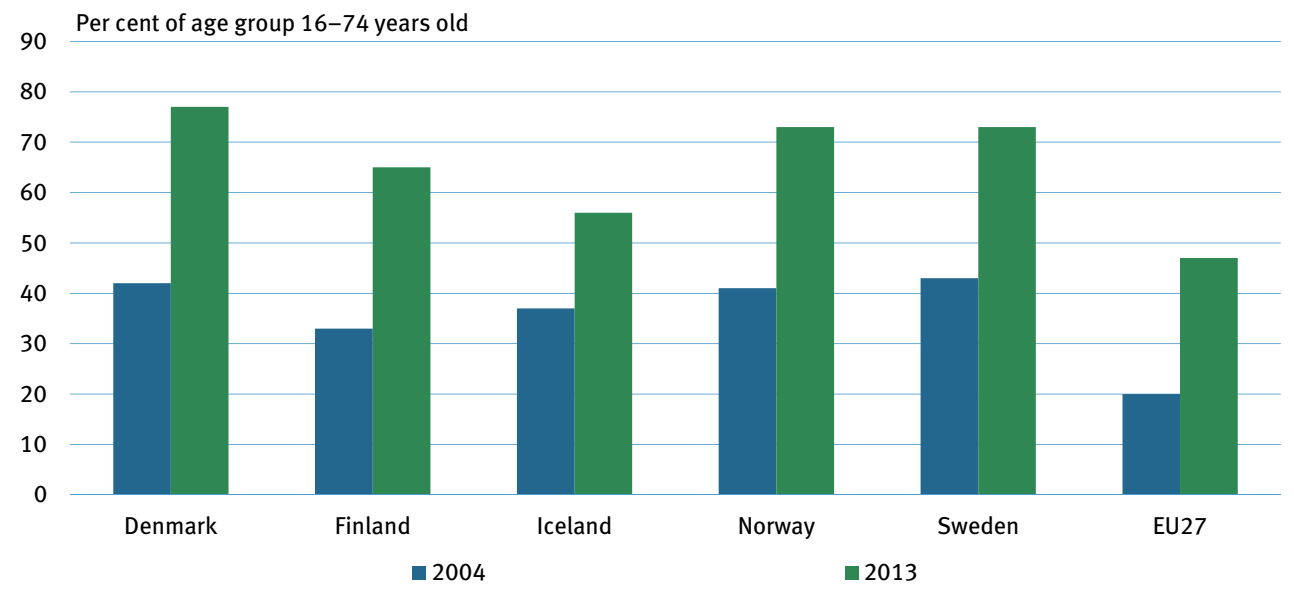

믄 Info13

Source: Eurostat.

7 member states of the European Union as per 1 January 2013

Not: EU27: De 27 medlemsstaterna i Europeiska unionen per 1 januari 2013. 
Appendix 1: User guide

The Nordic Statistical Yearbook 2014 is published by the Nordic Council of Ministers. There is free access to the pdf-version of the book and the database Nordic Statistics on the website of the Nordic Council of Ministers www.norden.org.

The database contains comparable statistics for Denmark, the Faroe Islands, Greenland, Finland, Åland, Iceland, Norway and Sweden. Data relating to Denmark do not include data on the Faroe Islands or Greenland. Figures for Åland are included in the Finnish figures, though figures for Åland are shown separately.

In connection with the 50 years jubilee lin 2012 a historical view of the development in the Nordic countries was produced. This review which shows the development within many different aspects of Nordic life over the last 50 years can be found on our webpage www.norden.org

\section{Languages}

The book is bi-lingual - English and Swedish. However, English is used as the primary language. For example, all tables will have two sets of references - one in English and one in Swedish - and all text will normally be in both languages. Following the Anglo-American tradition, decimals are separated by decimal points instead of by a comma.
The database: Nordic Statistics - www.norden.org

The $\square$ and the reference that appears below a table or diagram identifies the table in the database that has served as its source. All the tables may be found in the database. The reference after $\square$ also works as a link to the current database-table. With a click on the reference you get directly into the table in question.

It is only a selection of the data from the database that has been included in the book's tables and graphs. In particular, time series are to be found in the database.

To download data from the database you can choose Excel o PC-Axis. If you choose PC-Axis, you need to install the PC-Axis software, which is located on the site. If you already have the program installed on your computer, you do not necessarily need to re-install it, unless you wish to benefit from the newest features.

The PC-Axis programme enables you to manage large amounts of statistical data. In PC-Axis, it is possible to extract a selection of data from a table, e.g. data for only one country or, perhaps, all the countries or, perhaps, just data from the latest year. The programme also allows you to rearrange tables, e.g. by aggregating variables, calculating percentages, etc., and to export the tables into a variety of different file formats.

\section{Sources and notes}

Most figures come from the national statistical institutes. Sources are nevertheless provided below all tables and graphs. Notes are normally only provided for tables and graphs.

All tables are numbered as a continuous series within the specific chapter, as are the diagrams. The subject index in the back of the book refers only to pages.

\section{Data and data collection}

Most data derive from the Nordic national statistical institutes, as the production and dissemination of statistics in the Nordic countries are centralized. The national statistical institutes are responsible for producing or coordinating the production of official statistics. They all operate independently of government control and their activities are regulated by law.

Although excellent comparisons may be made between the Nordic countries on the basis of the data provided, care must be taken to allow for differences in primary data and the way they are collected, organized and calculated. Notes to explain differences in comparability and methodology are normally provided. 


\section{Contact information}

The decision of which data to include in the Nordic Statistical Databank is made by the Working Group on Nordic Statistics. The group is chaired by the editor of the Nordic Statistical Databank and Yearbook, Klaus Munch Haagensen (kmh@dst.dk), and includes representatives of the Nordic national statistical institutes (NSIs):

Denmark:

Klaus Munch Haagensen, kmh@dst.dk Troels A. Vestergaard, tav@dst.dk

Faroe Islands: Simona Nielsen, simona@hagstova.fo

Greenland: Bolatta Vahl, bova@stat.gl

Finland:_Leena Paloniemi, leena.paloniemi@stat.fi

Leo Kostiainen, leo.kostiainen@stat.fi

Åland:

Island:

Iris Åkerberg, iris.akerberg@asub.ax

Svava Gudjonsdottir,

Svava.Gudjonsdottir@hagstofa.is

Norway:

Ingrid Modig, ingrid.modig@ssb.no

Bjarte Mellemstrand,

bjarte.mellemstrand@ssb.no

Sweden:

Linda Larsson Conteh,

linda.larsson-conteh@scb.se

Camilla Aronsson, camilla.aronsson@scb.se
To obtain additional information on statistics from individual Nordic countries, please use the following contact addresses:

Statistics Denmark, Library and Information

tel.: +4539173030

e-mail: bib@dst.dk

Internet: www.dst.dk

\section{Statistics Faroe Islands}

tel.: +298352800

e-mail: hagstova@hagstova.fo

Internet: www.hagstova.fo

\section{Statistics Greenland}

tel.: +299345770

e-mail: stat@stat.gl

Internet: www.stat.g|

Statistics Finland, Library of Statistics, Information Service tel.: +358917342220

e-mail: kirjasto.tilastokeskus@stat.fi

Internet: www.stat.fi
Statistics Åland

tel.: +358 1825490

e-mail: info@asub.ax

Internet: www.asub.ax

Statistics Iceland, Information Services

tel.: +3545281000

e-mail: information@statice.is

Internet: www.statice.is

Statistics Norway, Information Centre

tel.: +47 21094642

e-mail: informasjon@ssb.no

Internet: www.ssb.no

Statistics Sweden, Information service

tel.: +46850694801

e-mail: information@scb.se

Internet: www.scb.se 
Bilaga 1: Användarhandledning

Nordisk statistisk årsbok 2014 publiceras av Nordiska ministerrådet. Det finns gratis tillgång till pdf-versionen av boken och databasen Nordic Statistics på webbplatsen för Nordiska ministerrådet.

Databasen innehåller jämförande statistik för Danmark,

Färöarna, Grönland, Finland, Åland, Island, Norge och Sverige.

Uppgifter som avser Danmark inkluderar inte uppgifter om

Färöarna eller Grönland. Uppgifter för Åland ingår i uppgifterna

för Finland även om de anges separat.

I samband med 50-årsjubileet i 2012 tog vi fram en historisk bild av utvecklingen i Norden. Den visar utvecklingen inom många olika aspekter av livet i Norden under de senaste 50 åren och finns på vår hemsida www.norden.org.

\section{Språk}

Boken är tvåspråkig - på engelska och svenska. Engelska används emellertid som huvudspråk. Alla tabeller har två uppsättningar referenser - en på engelska och en på svenska - och all text finns normalt på bägge språken. På anglosaxiskt sätt anges decimaler med punkt i stället för med komma.
Databasen: Nordic Statistics - www.norden.org

Symbolen ${ }^{0}$ under en tabell eller ett diagram markerar en

hänvisning till den tabell i databasen som utgör källan. Alla

tabeller finns i databasen. Hänvisningen efter 回 länkar till den aktuella databastabellen. Med ett klick på referensen kommar du direkt till rätt tabell.

Det är bara ett urval av data från databasen som finns med $\mathrm{i}$ bokens tabeller och diagram. I synnerhet tidsserier finns i databasen.

När du hämtar data från databasen kan du välja excel eller PCAxis. Om du väljer PC-Axis behöver du installera PC-Axis mjukvaran, som ligger på webbplatsen. Om du redan har programmet installerat på din dator behöver du inte nödvändigtvis installera om det, om du inte vill dra nytta av de nyaste funktionerna.

Med programmet PC-Axis är det möjligt att hantera stora mängder av statistiska data. Man kan göra ett urval av data från en tabell, t.ex. uppgifter för endast ett land eller, i stället, alla länder eller, om man så önskar, bara uppgifter från det senaste året. PC-Axis låter också användaren göra om tabellerna, t.ex. genom att aggregera variabler och beräkna procenttal, samt exportera tabellerna till en mängd olika filformat.

\section{Källor och noter}

Huvuddelen av uppgifterna kommer från de nationella statistiska instituten, men källorna anges ändå under alla tabeller och diagram.

Alla tabeller är numrerade som en kontinuerlig serie inom varje enskilt kapitel, liksom diagrammen. Sakregistret i slutet av boken hänvisar endast till sidor.

\section{Uppgifter och insamling av uppgifter}

Merparten av uppgifterna är hämtade från de nordiska nationella statistiska instituten, eftersom sammanställningen och spridningen av statistik är centraliserad i de nordiska länderna. De nationella statistiska instituten svarar för officiell statistik antingen genom att sammanställa den själv eller genom att samordna produktionen av den. De är alla självständiga organ med lagreglerad verksamhet.

Även om uppgifterna i boken ger möjlighet till utmärkta jämförelser mellan de nordiska länderna, måste man ta hänsyn till skillnader i primära uppgifter och det sätt på vilket de samlas in, bearbetas och beräknas. Noter om skillnader i jämförbarhet och metoder lämnas normalt. 
Kontaktinformation

Arbetsgruppen för Nordisk Statistik bestämmer vilka uppgifter som skall inkluderas i den nordiska statistiska databasen. Gruppen leds av redaktören för den nordiska statistiska databasen och årsboken, Klaus Munch Haagensen (kmh@dst.dk), och innehåller representanter för alla NSI, nämligen:

\section{Danmark:}

Klaus Munch Haagensen, kmh@dst.dk

Troels A. Vestergaard, tav@dst.dk

Färöarna:

Grönland: Simona Nielsen, simona@hagstova.fo

Finland:

Bolatta Vahl, bova@stat.s

Leena Paloniemi, leena.paloniemi@stat.fi

Leo Kostiainen, leo.kostiainen@stat.fi

Åland:

Island:

Iris Åkerberg, iris.akerberg@asub.ax

Svava Gudjonsdottir,

Svava.Gudjonsdottir@hagstofa.is

Norge: Ingrid Modig, ingrid.modig@ssb.no Bjarte Mellemstrand,

bjarte.mellemstrand@ssb.no

Sverige:

Linda Larsson Conteh,

linda.larsson-conteh@scb.se

Camilla Aronsson, camilla.aronsson@scb.se
Ytterligare information om statistik från de enskilda nordiska

länderna kan fås på följande kontaktadresser:

Danmarks Statistik, Bibliotek og Information

tel.: +4539173030

e-mail: bib@dst.dk

Internet: www.dst.dk

\section{Hagstova Føroya}

tel.: +298352800

e-mail: hagstova@hagstova.fo

Internet: www.hagstova.fo

\section{Grønlands Statistik/Naatsorsueqqissaartarfik}

tel.: +299345770

e-mail: stat@stat.gl

Internet: www.stat.gl

Statistikcentralen/Tilastokeskus,

Statistiska biblioteket, Informationsservice

tel.: +358917342220

e-mail: kirjasto.tilastokeskus@stat.fi

Internet: www.stat.fi

\section{Ålands statistik- och utredningsbyrå}

tel.: +3581825490

e-mail: info@asub.ax

Internet: www.asub.ax

Hagstofa Íslands, Upplýsingapjónusta

tel.: +3545281000

e-mail: information@statice.is

Internet: www.statice.is

Statistisk sentralbyrå, informasjonstjenesten

tel.: +4721094642

e-mail: informasjon@ssb.no

Internet: www.ssb.no

Statistiska centralbyrån, Information och bibliotek

tel.: +46850694801

e-mail: information@scb.se

Internet: www.scb.se 


\section{Appendix 2: Geonomenclature}

The Nordic countries: Denmark, Finland, Iceland, Norway, Sweden, Faroe Islands, Greenland and Åland.

EA: Members of the European Union who have adopted the Euro as their common currency. EA11 (1999-2000): Austria, Belgium, Finland, France, Germany, Ireland, Italy, Luxembourg, Netherlands, Portugal, Spain.

EA12 (2001-2006): EA11 + Greece. EA13 (2007): EA12 + Slovenia. EA15 (2008): EA13 + Cyprus , Malta. EA16 (2009-2010): EA15 + Slovakia. EA17 (2011-2014): EA16 + Estonia. EA18 (2014-): EA17 + Latvia

EU27 (as per 1 January 2013): The 27 memberstates of the European Union. Austria, Belgium, Bulgaria, Cyprus, Czech Republic, Denmark, Estonia, Finland, France, Germany, Greece, Hungary, Ireland, Italy, Latvia, Lithuania, Luxembourg, Malta, Netherlands, Poland, Portugal, Romania, Slovakia, Slovenia, Spain, Sweden and United Kingdom.

EU28 (as pe 1 January 2014): EU27 + Croatia

EEA - European Economic Area: EU27 + Norway, Iceland and Liechtenstein.

The Baltics: Estonia, Latvia and Lithuania.

Other Europe: Albania, Andorra, Belarus, Bosnia and Herzegovina, Kosovo, Serbia-Montenegro, Former Yugoslav Republic of Macedonia, Gibraltar, Moldova, Montenegro, Russian Federation, San Marin, Switzerland, Turkey, Ukraine, Vatican City.

Africa: Egypt and South Africa + OPEC-Africa + Other Africa.

OPEC-Africa: Algeria, Libya, Nigeria and Gabon.
Other Africa: Angola, Benin, Botswana, British Indian Ocean Territory, Burkina Faso, Burundi, Cameroon, Cape Verde, Central African Republic, Ceuta and Melilla, Chad, Comoros, Congo (Dem. Rep.), Congo (Republic), Djibouti, Equatorial Guinea, Eritrea, Ethiopia, Gambia, Ghana, Guinea, Guinea-Bissau, Ivory Coast, Kenya, Lesotho, Liberia, Madagascar, Malawi, Mali, Mauritania, Mauritius, Mayotte, Morocco, Mozambique, Namibia, Niger, Rwanda, Sao Tomé and Principe, Senegal, Seychelles and dependencies, Sierra Leone, Somalia, Saint Helena and dependencies, Sudan,

Swaziland, Tanzania, Togo, Tunisia, Uganda, Zambia and Zimbabwe.

America: United States of America (USA), Canada and Brazil + OPEC-America + Other America.

OPEC-America: Ecuador and Venezuela.

Other America: Anguilla, Antigua and Barbuda, Argentina, Aruba, Bahamas, Barbados, Belize, Bermuda, Bolivia, British Virgin Islands, Cayman Islands, Chile, Colombia, Costa Rica, Cuba, Dominica, Dominican Republic, El Salvador, Falkland Islands, Grenada, Guatemala, Guyana, Haiti, Honduras, Jamaica, Mexico, Montserrat, Netherlands Antilles, Nicaragua, Panama, Paraguay, Peru, Saint Kitts and Nevis, Saint Lucia, Saint Pierre and Miquelon, Saint Vincent, Surinam, Trinidad and Tobago, Turks and Caicos Islands, Uruguay and US Virgin Islands.

BRIC: Brazil, Russian Federation, India and China.

Asia: China, India, Israel and Japan + OPEC-Asia + DAE + Other Asia.

OPEC-Asia: Iran, Iraq, Indonesia, Kuwait, Qatar, Saudi Arabia and United Arab Emirates.

DAE (Dynamic Asian Economies): Hong Kong, Malaysia, Singapore, South Korea, Taiwan and Thailand.
Other Asia: Afghanistan, Armenia, Azerbaijan, Bahrain, Bangladesh, Bhutan, Brunei, Cambodia, Georgia, Jordan, Kazakhstan, Kyrghyzstan, Laos, Lebanon, Macao, Maldives, Mongolia, Myanmar, Nepal, North Korea, Oman, Pakistan, Philippines, Sri Lanka, Syria, Tajikistan, Turkmenistan, Uzbekistan, Vietnam, West Bank and Gaza Strip and Yemen.

\section{Oceania: Australia + Other Oceania.}

Other Oceania: American Samoa, Australian Oceania, Federated States of Micronesia (Yap, Kosrae, Chuuk and Pohnpei), Fiji, Kiribati, French Polynesia, Marshall Islands, Nauru, New Caledonia and dependencies, New Zealand, New Zealand Oceania, Northern Mariana Islands, Palau, Papua New Guinea, Pitcairn, Polar Regions, Solomon Islands, Tonga, Tuvalu, Vanuatu, Wallis and Futuna Islands and Western Samoa.

Other and unknown: Stores and provisions, other countries and territories not determined or disclosed. 


\section{Sakregister}

aborter 42

adoption, havandeskapspenning 64

aktiekurser 127

aktiekursindex 98,127

alkohol 57

alternativ energi 33-34

ammoniak $\left(\mathrm{NH}_{3}\right) 29$

arbetsfrånvaro 62

arbetskraft 82

byggindustri $86-87$

deltidsanställning 88

FoU 136

T-sektorn 141

jordbruk, skogsbruk och fiske 131

kön $82,86,88$

näringsgren 87,104

servicenäringar 105

tillverkningsindustri $\quad 86-87$

arbetslöshet 7,83-85

kön 84

procent $7,83-85$

ungdomar 85

arbetslöshetsprocent $\quad 7,83-85$

arbetsmarknad 81-88

area

ekologisk 32

glaciärer 9-16, 23

land 7, 22-23

sjöar 9-16, 23

skog 9-16, 23

total $7,9-16,22-23$ vatten 9-16, 23

åkermark 23

asylansökningar 49-50

ensamkommande barn 50

medborgarskap 49

barn

barnomsorg 63

ensamkommande 50

familjer med/utan 43

placerat utanför hemmet 63

sociala utgifter 60

socialbidrag 60

befolkning 7, 9-16, 22-23, 35-50

civilstånd 44-45

förändringar 20, 39

huvudstäder 7, 9-16, 22

invånare per $\mathrm{km} 7,23$

migration $39,46-48$

nordiska medborgare i annat nordiskt land 46-48

total 7,9-16, 23

utländska medborgare $\quad 46-48$

befolkningsförändringar 39

befolkningsprognoser 40

befolkningstäthet 23

bekämpningsmedel 31

betalningsbalans 98,101-102

betesmark 23

bibliotek 96

bistånd till utvecklingsländer 121

BNP 7, 20, 98-99, 107, 116-118, 125

per person $7,99,125$

boende, äldre 60-61 bostäder 68-69

bostäder och byggande 67-69

bruttoförädlingsvärde 104-105

servicenäringar 105

tillverkningsindustri 104

bruttonationalinkomst (BNI) 120

bruttonationalprodukt (BNP) 7, 20, 97-99, 107, 116-118, 125

per person $7,99,125$

bruttoskuld 119

budgetunderskott 118

byggindustri, sysselsättning 86

bytesbalans 101, 106

böcker, bibliotek 96

cancer 54-55

bekräftade nya fall 55

$\mathrm{CH}_{4}$ (metangas) 26

civilstånd 44-45

$\mathrm{CO}_{2}$ (koldioxid) 7, 26

daghem, barn 63

deltidsanställning 88

dikväveoxid $\left(\mathrm{N}_{2} \mathrm{O}\right) \quad 26$

disponibel inkomst

hushåll 65

kön 66

döda $39,54,56$

cancer 54

hjärt- och kärlsjukdomar 54

olycka 54

självmord 54, 56

dödlighet 55

dödsorsaker 54 
priser 68

fattigdom, relativ 59

ekologiskt jordbruk 32

ekonomiskt bistånd 60, 62, 64

ekonomisk tillväxt 98-99

ekonomiska nyckeltal 7,98

ekonomiska tendenser 97-98

elever, se studenter

emigration $39,46,48$

emission 7, 26-27, 29

energi 33-34

energiförbrukning 34

per person 7,34

energiproduktion 7,33

energitillgång 34

ensamkommande barn

ålder 50

Europaparlamentet, val 91

export 106-113

handelsbalans 102, 108

index 107

land 110-111

till nordiska länder 109-111

utomnordisk 109-111

varor och tjänster 102, 108

varugrupp 112

familjer 43

inkomst 65

med/utan barn 43

fasta bruttoinvesteringar 100

fasta bränslen 33-34

fastighet 67

index 68 fertilitet 7,41

filosofie doktorer 139

fiske 131, 133

fiske, se också jordbruk, skogsbruk och fiske 129, 133-134

fiskefångster 133

folkmängd 7, 9-16, 22-23, 35-50

civilstånd 44-45

förändringar 39

huvudstäder 7, 9-16, 22

invånare per km 7,23

migration 39, 46-48

nordiska medborgare i annat nordiskt land $46-48$

totalt $7,9-16,23$

utländska medborgare $\quad 46-48$

folkökning 39

forskning och utveckling (FoU) 135-139

fosfor (P) 30

FoU 135-142

anställda 136

filosofie doktorer 139

patent 139

personal 136

statliga utgifter $136-138$

utgifter 137-138

fritid $92-96$

fruktsamhet 7,41

födda 39,41

havandeskapspenning 64

företags samspel med offentliga myndigheter 140

fornyelsebara energikällor 33-34

föroreningar 26-27

jord 26-27, 29-31 luft 26-27, 29-31

vatten $26-27,29-31$

försurning 26-27, 29-3

försörjningsbalans 100

försörjningsbörda 38,40

förväntad livslängd 7,37

föräldrapenning 64

gas $33-34$

geografi $21-27$

geotermisk energi $33-34$

gifta 44-45

giftermål 44-45

gini-koefficient 59

glaciärer, se areal

global uppvärmning 26-27

grödor 131

produktion 131

gödningsmedel 30

handelsbalans 102, 108

handelsgödsel 30

hushåll, inkomst 66

huvudstad, folkmängd 9-16

hälso- och sjukvårdspersonal 53

hälsovård 51-57

hållbar utveckling 18-20

icke-medborgare

utvandring 46,48

invandring $46-47$ 
nordiska medborgare i annat nordiskt land 46-48 immigration $39,46-47$

import

handelsbalans 102, 108

index 107

land 110-111

till nordiska länder 109-111

utomnordisk 109-111

varor och tjänster 102,108

varugrupp 113

individers samspel med offentliga myndigheter 141 industri 104

inflation 98

inhemsk energiproduktion 33-34

inkomst 65-66

disponibel 65-66

hushåll 65

kön 66

offentliga sektorn 117

inkomstfördelning 65-66

insektsmedel 31

internationellt bistånd $\quad 120-121$

Internet

användning 141

köp 143

privat tillgång 142

samspel 141

invandring $39,46-47$

land 47

investeringar, utländska 101

invånare per km 7, 9-16, 23 jordbruk

bekämpningsmedel 31

ekologisk 32

handelsgödsel 30

vegetabilisk produktion 131

åkermark 32

jordbruk, skogsbruk och fiske 129-134

sysselsättning 131

jordföroreningar 26-27

jordvärme 33-34

kalium (K) 30

klimat 21-25

koldioxid $\left(\mathrm{CO}_{2}\right) \quad 7,26$

konstgödsel 30

konsumentprisindex 122-123

konsumtion

alkohol 57

bekämpningsmedel 31

energi 7,34

handelsgödsel 30

livsmedel 122

offentliga sektorn 100

privat 100

kultur 92-96

kväve (N) 30

kväveoxider (NOx) 30

kärnkraft 33-34

köpkraftspariteter (PPS) 65-66, 99, 125 landareal 9-16, 23

levande födda 39, 41

livslängd 37-39

luftföroreningar 26-27, 29-31

läkare 53

markanvändning 23

medellivslängd 7,37

metangas $\left(\mathrm{CH}_{4}\right) \quad 26$

migration $39,46-48$

miljö 28-34

mobiltelefonabonnemang 143

museibesök 94

musik

digitalt 95

försäljning 95

nationella val 90

naturgas $33-34$

naturlig folkökning 39,41

nettoexport 106-109

nettomigration 39

nettoskatter 117

nettoskuld 118-119

nettotillgång 101

$\mathrm{NH}_{3}$ (ammoniak) 29

$\mathrm{N}_{2} \mathrm{O}$ (dikväveoxid) 26

nordiska medborgare i annat nordiskt land $46-48$

$\mathrm{NO}_{\mathrm{x}}$ (kväveoxider) 30

nyckeltal, ekonomiska 7,98 
offentlig ekonomi och priser $114-128$ offentliga myndigheter, samspel med

företag 140

individer 140

offentliga sektorn

inkomster 117

underskott 118

överskott 7,98, 118

offentliga sektorns utgifter 93, 136-137

offentlig skuld 7, 20, 98, 118-119

offentlig överskott 117

ogifta 44-45

ogräsmedel 31

olja 33-34

ozonuttunnande ämnen 26-27

papper 132

partiklar 26

partnerskap, avregistrerade 45

partnerskap, registrerade 45

patent 139

pension 61

pensionärer 61

permanent ängsmark 23

PISA 78

prisindex

inflation 98

konsumentpriser 122-123

prisnivåer 122, 124

privat konsumtion 100 realtillväxt 99

relativa arbetskraftstal 82

risk för fattigdom 59

räntenivå 98,128

rökning 57

röstning 89-91

samer 17

separerade 44-45

serviceboende 60

servicenäringar 85-86, 105

bruttoförädlingsvärde 105

sysselsättning $85-86,105$

sjukdomar

cancer 54-55

hjärt- och kärl 54

sjukfrånvaro 62

sjukvård

utgifter, sjukvård $\quad 52,115-116$

sjukvårdskostnader 52,115-116

sjukvårdspersonal 53

självmord 54, 56

sjöar 9-16, 22-23

skatter 7,117

skattetryck 7

skilda 44-45

skilsmässor 44-45

skogsbruk 9-16, 23

skogsmark 7,9-16, 23

skulder 20,98, 101, 118-119

skulder, offentliga sektorn $98,101,118-119$

socialbidrag 60-61, 64 föräldrapenning 64

havandeskapspenning 64

mottagare 60-61, 64

social integration $58-64$

social trygghet 115-116

sociala utgifter 60

$\mathrm{SO}_{\mathrm{X}}$ (svaveloxider) 29

spannmål 131

studenter

examinerade 74

inskrivna 72

studiestöd 79

utomlands 80

studerandes läskunnighet 78

studiestöd 79

svampmedel 31

svaveldioxid $\left(\mathrm{SO}_{\mathrm{x}}\right) \quad 29$

sysselsättning $81,86-87$

relativa arbetskraftstal 82

sysselsättningsintensitet 82

tandläkare 53

teater 94

teknologi 140-142

temperatur 25

tillgångar 101, 118

tillverkningsindustri 104

bruttoförädlingsvärde 104

produktionsindex 104

sysselsättning $86-87,104$

tjänstenäringar 86-87, 105

bruttoförädlingsvärde 105

sysselsättning 86-87,105 
träproduktion 132

trämassa 132

träprodukter 132

U

utbildning $70-80$

examinerade 74

inskrivna 72

studenter, utomlands 80

utgifter, offentliga 71

utbildningsnivå 75-77

utbildningssystem 70

utlandsskuld 98, 101

utländska direktinvesteringar 103

utländska medborgare $\quad 46-48$

invandring 46-47

nordiska medborgare i annat nordisk land 46-47

utvandring 46,48

utländska tillgångar och skulder 98,101

utrikeshandel 106-113

handelsbalans 102, 108

index 107

inomnordisk 109-111

land 110-111

utomnordisk 110-111

varor och tjänster 102, 108

varugrupp 112-113

utsläpp 7,26-27, 29

utsläpp till jord 26-27, 29-31

utsläpp till luft 26-27, 29-31

utsläpp till vatten $\quad 26-27,29-31$

utvandring $39,46,48$

land 48

utvecklingsbistånd 121 val 89-91

Europaparlamentet 91

invalda ledamöter 90-91

giltiga röster 90

nationella 90

valutakurser 126

valutakursindex 98

varor och tiänster 102,108

varor och tjänster, utrikeshandel 102,108

varu- och tjänstebalans 102,108

vatten, föroreningar 26-27

vattenareal $9-16,23$

vattenkraft $33-34$

vegetabilisk produktion 131

vetenskap 135-140

växelkurser 126

växthusgaser 7,6-27

vårdplatser, sjukhus 53

äktenskap 44-45

äktenskapsskillnader 44-45

ängsmark 23

änklingar/änkor 45

$\AA$

åkermark 7, 23

ålderdom

serviceboende 60

utgifter 60

åldrande befolkning 38,40

årlig realtillväxt 99 


\section{Subject index}

abortions 42

absence from work 62

acidification 26-27, 29-31

activity rates 82

adoption, cash benefits 64

age burden 38,40

ageing population 38,40

agriculture

arable land 130

crop production 131

fertilizers 30

organic 32

pesticides 31

agriculture, forestry and fishery $129-134$

employment 86-87

aid to developing countries 121

air pollution 26-27, 29-31

alcohol 57

alternative energy 33-34

ammonia $\left(\mathrm{NH}_{3}\right) 29$

arable land 7,23

forests $7,9-16,23$

icecap 9-16, 23

lakes 9-16, 23

land 7, 22-23

organic 32

total $7,9-16,22-23$

water 9-16, 23

assets 98, 101

asylum requests $49-50$ unaccompanied children 50

citizenship 49

balance of goods 102,108

balance of goods and services 102,108

balance of payments $98,101-102$

balance of trade 108

beds, hospitals 53

births 39,41

cash benefits 64

books, libraries 96

budget deficit 118

cancer 54-55

confirmed new cases 55

capital (area) population 9-16

carbon dioxide 7,26

cash benefits $60,62,64$

adoption 64

childbirth 64

pregnancy 64

sickness 62

causes of death 54

$\mathrm{CH}_{4} 26$

chemical fertilizers 31

childbirth, cash benefit 64

children

day-care centre 63

families with/without 43

placed outside their home 63

social assistance 60

social expenditure 60 unaccompanied 50

climate 24-27

$\mathrm{CO}_{2}$ (carbon dioxide) 7,26

commercial fertilizers 30

construction, employment $86-87$

consumer price index 122-123

consumption

alcohol 57

energy 7,34

fertilizers 30

food 124

pesticides 31

private 100

public 100

crop production 131

culture 92-96

currency reserve 98

day-care centres, children 63

deaths $39,54,56$

accidents 54

cancer 54

cardiovascular diseases 54

suicide 54,56

debt, public $20,98,101,118-119$

demographic change 39

dentists 53

development aid 120-121

diseases

cancer 54-55

cardiovascular diseases 54

disposable income

households 65 
sex 66

divorced persons $44-45$

divorces $44-45$

dwellings 67-69

economic growth 98-99

economic key figures 7,98

economic trends $97-98$

education $70-80$

expenditure, public 71

graduates 74

students abroad 80

students enrolled 72

educational level $75-77$

educational system 70

effective nominal exchange rate index 98,126

elections $89-91$

elected candidates 90-91

European parliament 91

national 90

valid votes $90-91$

elderly people, housing 60

emigration 39, 46, 48

country 48

emissions 7, 26-27, 29

employment 82

agriculture, forestry and fishery 131

by industry $86-87$

construction $86-87$

manufacturing 86-87, 104

part-time 88

R\&D 136

service sector 105 sex $82,86,88$

employment rates 82

energy 33-34

energy consumption 34

per capita 7, 34

energy production 34

energy supply 34

enterprises, interaction with public authorities 140

environment 28-34

European parliament, election 91

exchange rates 98,126

exports

balance of trade 102,108

commodities 112

country 110-111

goods and services 102, 108

index 107

intra-Nordic 109-111

external trade $106-113$

families 43

income 65

social expenditure 60

with/without children 43

fertility 7,41

fertilizers 30

fishery $131,133-134$

fishing, catches 133

foreign assets and liabilities 98, 101

foreign debt 98, 101

foreign direct investments 103

foreign exchange reserve 98

foreign trade 106-113 balance of trade 108,112

commodities 112-113

country 110-111

extra-Nordic 110-112

goods and services 102,108

index 107

intra-Nordic 109-111

foreigners $46-50$

emigration 46,48

immigration 46-47

Nordic citizens in Nordic countries $46-48$

forest $7,9-16,23$

forestry $129,131-132$

fungicides 31

gas $33-34$

GDP $7,20,98-99,107,116-118,125$

per capita $7,99,125$

general government expenditure

R\&D 136-139

culture 93

general government revenue 117

geography 21-27

geothermal energy 33-34

gini-coefficient 59

global warming 26-27

goods and services 102, 108

graduates 74

grain 131

production 131

greenhouse gases $7,26-27$

gross debt 118

gross domestic production (GDP) 
$7,98-99,107,116-118,125$

per capita $7,99,125$

gross fixed capital formation 100

gross national income (GNI) 120

gross value added 104-105

manufacturing 104

service sector 105

health care $51-57$

health care expenditure 52,115-116

health staff 53

herbicides 31

household, income 65

housing 67-69

index 68-69

prices 68

housing and construction $67-69$

hydropower 33-34

icecap area 9-16, 23

ICT sector 140-142

illness 62

absence from work 62

cash benefits 60

immigration $39,46-47$

country 47

import

balance of trade 102,108

commodities 113

country 110-11

goods and services 102, 108

index 107
intra-Nordic 109-111

income 65-66

general government 117

households 65

personal 65-66

sex 66

income distribution 65-66

indigenous energy production 33-34

individuals, interaction with public authorities 140

inflation 98

inhabitants per sq km 7, 9-16, 23

insecticides 31

interaction with public authorities

enterprises 140

individuals 140

interest rate 98,128

Internet 140-142

interaction 140

purchases 142

private access 141

use 141

investment, foreign direct 103

key figures, economic 7,98

labour force $7,82,86-88$

labour market $81-88$

lakes 9-16, 23

land area 9-16, 22-23

land use 23

leisure 92-96

liabilities 100-101, 118 libraries 96

life expectancy 7,37

live births 39,4

longevity 37-39

manufacturing

employment 86-87, 104

gross value added 104

marriages 44-45

married persons 44-45

marital status 44-45

maternity benefits 64

meadows 23

methane $\left(\mathrm{CH}_{4}\right) 26$

migration $39,46-48$

country 46-48

mobile subscriptions 142

mortality 54,56

museums, visits 94

music

digital 95

sale 95

$\mathrm{N}_{2} \mathrm{O}$ (nitrous oxide) 26

national elections 90

natural gas 33-34

natural population increase 39,41

net assets 101

net debt $118-119$

net export 106-108

net migration 39

net taxes 117 
$\mathrm{NH}_{3}$ (ammonia) 29

nitrogen $(\mathrm{N}) 30$

nitrogen oxides $\left(\mathrm{NO}_{\mathrm{x}}\right) 29$

nitrous oxide $\left(\mathrm{N}_{2} \mathrm{O}\right) 26$

non-nationals

emigration 46,48

immigration 46-47

Nordic citizens in Nordic countries 46-48

Nordic citizens in Nordic countries 46-48

$\mathrm{NO}_{x}$ (nitrogen oxides) 29

nuclear power 33-34

nursing homes 60

oil 33-34

old age pension 61

old age, social expenditure 60

organic farming 32

ozone depletion 26-27

paper 132

partnerships

dissolved 45

registered 45

particulates 26

partnerships, registered 45

part-time employment 88

sex 88

pastures 23

patents 139

pensioners 61

pensions 61

pesticides 31
PhD graduates 139

phosphorus 30

physicians 53

PISA 78

pollution $26-27$

air 26-27, 29-31

soil 26-27, 29-31

water $26-27,29-31$

population $7,9-16,22-23,35-50$

capital (area) 9-16, 22

change 20,39

inhabitants per sq km 7, 23

marital status $44-45$

migration $39,46-48$

non-nationals $46-48$

Nordic citizens in Nordic countries $46-48$

total 7,9-16, 23

population density 23

population projections 40

potassium 30

poverty, relative 59

pregnancy, cash benefits 64

price index

consumer prices $122-123$

inflation 98

price levels 122,124

price levels 122,124

private consumption expenditure 100

public balance deficit 118

public balance, surplus $7,98,118$

public consumption expenditure 100

public debt 7, 20,98,115-116, 118-119

public finance and prices $114-128$

public revenue 117 pulp 132

pupils, see students

purchasing power $65-66,99,124-12$

R\&D $135-142$

employment 136

expenditure 137-138

government appropriations 136-138

patents 139

PhD graduates 139

real annual growth 99

real estate 68

relative poverty 59

renewable energy 33-34

research and development 135-139

residential institutions 60

retirement pension 61

sami 17

science 135-139

separated persons 44-45

service housing 60

service sector

employment 86-87, 105

gross value added 105

share prices index 98,127

share prices 127

sickness

absence from work 62

cash benefits 60

sickness benefits 60

single persons 44-45 
smokers 57

social assistance $60-61,64$

adoption 64

childbirth 64

pensions 61

pregnancy 64

recipients $60-61,64$

sickness benefits 60

social expenditure 60

social integration $58-64$

social security $115-116$

soil pollution $26-27$

solid fuels 33-34

$\mathrm{SO}_{\mathrm{x}}$ (sulphur oxides) 26-27

student performance (PISA) 78

students

abroad 80

enrolled 72

financial support 79

graduates 74

study allowance 79

suicides 54,56

sulphur oxides $\left(\mathrm{SO}_{\mathrm{x}}\right) 29$

sustainable development $18-20$

tax burden 7

taxes 7, 117

technology 140-142

temperature 25

theatres 94

trade balance 102,108 unaccompanied children

age 50

unemployment $7,83-85$

rates $7,83-85$

sex 84

youth 85

unmarried persons $44-45$

voting $90-91$

water area 9-16, 23

water pollution 26-27

water power 33-34

widows/widowers 44-45

wood product, production 132 



\section{Unorden}

Nordic Council of Ministers

Ved Stranden 18

DK-1061 Copenhagen K

www.norden.org

\section{Nordic Statistical Yearbook 2014}

Nordic Statistical Yearbook is published for the $52 \mathrm{nd}$ time. It is a reference book containing comprehensive and easily accessible statistics of various aspects of social life in the five Nordic countries, i.e. Denmark, Finland, Iceland, Norway and Sweden. In addition data are also presented on the Faroe Islands, Greenland and the Åland Islands. The aim of the yearbook is, as far as possible, to present comparable data on the Nordic countries. Additional tables can be accessed free of charge via our homepage www.norden.org/facts. Here it is also possible to read and download the Nordic Statistical Yearbook in pdf format free of charge.

Nord 2014:001

ISBN 978-92-893-3850-9 (PRINT)

ISBN 978-92-893-3854-7 (PDF)

\section{Nordisk statistisk årsbok 2014}

Nordisk statistisk årsbok utkommer nu för 52:a gången. Årsboken är en uppslagsbok, som avser vara en sammanfattande och överskådlig redovisning av statistik över samhällsförhållandena i de fem nordiska länderna Danmark, Finland, Island, Norge och Sverige. I många av tabellerna redovisas också uppgifter om Färöarna, Grönland och Åland. Syftet med årsboken är att lägga fram sinsemellan jämförbara uppgifter om de nordiska länderna. Ytterligare tabeller finns tillgängliga gratis via vår hemsida www.norden.org/fakta. Här är det också möjligt att kostnadsfritt läsa och ladda ner boken i pdf-format. 